\title{
GERMAN EMPIRE
}

\author{
(BERLIN)
}




\section{BERLIN}

\section{FO 64/ro5o: Lord Ampthill to Earl Granville, No 91, Berlin, 7 April r884}

[Received io April by post. For: The Queen / Gladstone / X, Ch.W.D. [Charles Wentworth Dilke]; Prince of Wales; G[ranville]]

State governments oppose suggestion to create an imperial ministry responsible to the Reichstag

I have the honour to enclose to Your Lordship herewith in original and translation a Report given in yesterday's official Gazette of the proceedings in a plenary meeting of the Federal Council which took place on the $5^{\text {th }}$ Instant, at which The Imperial Chancellor ${ }^{1}$ was present in person. ${ }^{2}$

As reported in my Despatch $\mathrm{N}^{\mathrm{o}} 53$ of the $6^{\text {th }}$ ultimo the newly formed Parliamentary free minded fraction ${ }^{3}$ advocate in their programme the formation of a responsible Ministry for the Empire.

This seems to have excited the apprehension of some of the Federal Governments, and Saxony and Wurtemberg instructed their Representatives ${ }^{4}$ to make a declaration on the subject to the Federal Council on the $24^{\text {th }}$ ultimo and invite an interchange of views from the Prussian and other Governments.

At the meeting of last Saturday the Prussian Representatives ${ }^{5}$ handed in a declaration on the part of their Government, which is given "in extenso" in the enclosed Report.

The Prussian Government agrees with the Saxon Government in considering it absolutely necessary that the Federal States should

\footnotetext{
${ }^{\mathrm{I}}$ Otto von Bismarck.

${ }^{2}$ Enclosures: article (untitled) in Deutscher Reichsanzeiger und Königlich Preußischer Staatsanzeiger, 6 April I884 and translation.

${ }^{3}$ The liberal Deutsche Freisinnige Partei (German Free-Minded Party) was founded on 5 March I884 as a merger of the Reichstag factions of the Deutsche Fortschrittspartei (Party of Progess, founded in I86I) and the Liberale Vereinigung (Liberal Union or 'Secessionists'), a group that had broken away from the National Liberal Party in I88o. Their programme was disclosed on the same day.

${ }^{4}$ Oswald von Nostitz-Wallwitz and Fidel Baur von Breitenfeld.

${ }^{5}$ The sitting of the Federal Council of 5 April was attended by ten Prussian representatives.
} 
place on record, beyond the possibility of a doubt, their firm intention to maintain in their entirety the terms of the Federal engagements on which the union of the German States rests, considering that any step which would shake the confidence of the States in the stability of those engagements would be fraught with danger.

The Prussian Government is firmly convinced not only that a system of Imperial Government by responsible Ministers could not be introduced without sacrificing some of the essential rights of Government secured by Treaty to the Separate States ${ }^{6}$ but also that Parliamentary Government, subordinating Ministers to the decisions of changeable majorities in the Reichstag would inevitably lead to the dissolution of the Union and the Downfall of the Empire.

Under the circumstances it is of opinion that the scheme should be strenuously opposed whenever and wherever advanced.

The Representatives of Bavaria ${ }^{7}$ and all the other States having expressed agreement with these views the Council unanimously resolved to adhere to the terms of the Prussian Declaration.

\section{FO 64/1 Io2: Lord Ampthill to Earl Granville, No 92, Berlin, 8 April I884}

[Received I4 April by Messenger Cavendish. For: The Queen / X, Ch.W.D. [Charles Wentworth Dilke] / African Department; Qy: Colonial Office, I5 April I884; T.V.L. [Thomas Villiers Lister]]

\section{Society for German Colonization founded in Berlin}

With reference to my despatch No. 59 February I4 ${ }^{\text {th }}$ I883, and to Sir John Walsham's No. 254 of August 3I. I883, I have the honour to report to Your Lordship that a new colonization Society ${ }^{8}$ has just been started at Berlin with the avowed object of Founding German Agricultural and Trading Colonies.

The Chief promoters of this Society which has apparently no connection with the Frankfurt Society or the Bremen Firm, ${ }^{9}$ whose efforts in the same direction were reported on in the despatches above referred to, appear to be Count Behr Bandelin the President, Major von Mechsow [sic] the African traveller, Doctor

\footnotetext{
${ }^{6}$ This declaration alluded to the North German Confederation Treaty of I8 August I866 and the 'November Treaties' of I870.

${ }^{7}$ On 5 April Bavaria was represented by Emil von Xylander and Ferdinand von Raesfeldt.

${ }^{8}$ Gesellschaft fur deutsche Kolonisation, founded on 28 March I884.

${ }^{9}$ Ampthill is referring to the Deutscher Kolonialverein and the trading firm owned by Adolf Lüderitz.
} 
Peters, and the African Missionary Doctor Merenski who spoke at the Inaugural meeting of the Society on the $4^{\text {th }}$ instant.

Africa was indicated as the most suitable and available field for German Colonization, and the Aims to be embodied in the Statutes were unanimously decided on as follows:-

I. To collect funds for the object of the Society.

2. To discover and acquire suitable districts for colonization.

3. To direct the stream of German emigration to these districts.

It was stated that the number of German Emigrants to the United States of America in $\mathrm{I}_{88} 3$ was 194,490. Of this number 25, I90 belonged to the commercial and industrial classes.

There is no reason to suppose that the German Government will be more disposed to lend its countenance to the efforts of this Society than it has been in the case of similar movements in the past.

\section{FO 64/1102: Lord Ampthill to Earl Granville, No ro2, Berlin, 23 April 1884}

[Received 28 April by Messenger Taylor. African Department; Print; Copy to: Colonial Office / Admiralty, 8 May $]^{\text {to }}$

Nachtigal's mission to improve German trading interests on west coast of Africa

With reference to my Despatch $\mathrm{N}^{\mathrm{o}} 93$ of the $9^{\text {th }}$ instant I have the honour to inform Your Lordship that the semi-official Nord Deutsche Zeitung of the $2 \mathrm{I}^{\text {st }}$ instant, ${ }^{\text {11 }}$ gives some further information respecting the object of $\mathrm{D}^{\mathrm{r}}$ Nachtigal's Mission to the West Coast of Africa. ${ }^{12}$

The Nord Deutsche states that the happy increase in the commercial relations of Germany with the West Coast of Africa, and the evident need felt that the interests of German Commerce should not be left to the protection of trading-consuls[,] have induced the Foreign

\footnotetext{
${ }^{10}$ Notes on docket: 28 April I884: 'This is a movement that must be watched and I think no time should be lost in deciding what we tell to our Consulates [.] Copy $\left(\right.$ Conf $\left.^{\mathrm{d}}\right)$ to Admiralty asking that Admiral Salmon may be asked to ascertain \& report what the Germans are doing. Copy to Colonial Office with copy of letter to Admiralty; Shew to Consul Hewett, Drafts, 9 May. Print (Congo and Oil Rivers). Write with compliments to Head of Berlin Chancery and tell him to number this and any subsequent dispatch on the same subject in the African Section.' H.P.A. [Henry Percy Anderson]; G[ranville]].

${ }^{11}$ Norddeutsche Allgemeine Zeitung.

${ }^{12}$ On 29 March 1884 Nachtigal was appointed imperial commissioner for West Africa (Reichskommissar) and ordered to Lisbon to await further instructions.
} 
Office to send out $\mathrm{D}^{\mathrm{r}}$ Nachtigal to those parts, a person particularly suited for such a duty, to further German interests there and to report upon a scheme for consular appointments on that Coast. $\mathrm{D}^{\mathrm{r}}$ Nachtigal takes with him, at this own request, the African traveler $\mathrm{D}^{\mathrm{r}}$ Buchner, and likewise Herr Moebius now a Secretary at the German Consulate-General in London.

It is intended, at the suggestion of the Foreign Office, to station permanently some war vessels on the West Coast of Africa, and for the present the Gunboat "Möwe" has been placed at the service of the Commission. The "Möwe" left Kiel on the $\mathrm{I}^{\text {th }}$ instant and is expected at Lisbon towards the end of the month, where it will take on board $\mathrm{D}^{\mathrm{r}}$ Nachtigal and his staff.

\section{FO 64/1102: Lord Ampthill to Earl Granville, Confidential, Africa, No 5, Berlin, 30 May 1884}

[Received 2 June by Messenger Taylor. For: The Queen / X, Ch.W.D. [Charles Wentworth Dilke]; Copy to: Colonial Office, Io June I884; G[ranville]]

\section{False reports in British press regarding German takeover of Angra Pequena}

With reference to Your Lordship's despatch No. I42 of the $22^{\text {nd }}$ instant, enclosing copies of despatches relative to the question of the right of Sovereignty over Angra Pequeña as well as to my despatch No. 4 Africa, of the $27^{\text {th }}$ instant, I have the honour to state that the report in the Standard of May $4_{4}^{\text {th }}$ respecting the alleged assumption of the Sovereignty of that Territory by the German Government is unfounded. ${ }^{\mathrm{I}}$

The German Government are still awaiting an answer from Your Lordship to Count Münsters Letter of the $3 \mathrm{I}^{\text {st }}$ of December last ${ }^{14}$ and the premature reports in the Press about the taking possession of Angra Pequeña by the German Government are due to the great and growing impatience of the German people for the inauguration of a Colonial policy by Prince Bismarck, who has hitherto shewn no inclination to satisfy their cravings for colonies; beyond sending Doctor Nachtigall on board the "Moewe" to report generally on the West Coast of Africa as reported to you in my despatches Nos: 93 and 102 of the $9^{\text {th }}$ and $23^{\text {rd }}$ of April last, respectively.

\footnotetext{
${ }^{13}$ In a telegram of 24 April I884 Bismarck instructed the German consul at Cape Town to declare that the coastal area of Angra Pequena, acquired by the Bremen merchant Adolf Lüderitz in 1883 , was under German protection.

${ }^{14}$ In his note to Granville of ${ }_{3}$ I December 1883 , Münster enquired whether Britain claimed sovereignty over Angra Pequena.
} 


\section{FO 64/1103: Lord Ampthill to Earl Granville, No 225, Berlin, 18 August 1884}

[Received 2I August by post. For: Lord Derby; X, Ch.W.D. [Charles Wentworth Dilke]; G[ranville]]

German press reports about British expansion on African west coast; concern that this might affect German colonial aspirations

The "Nord Deutsche Allgemeine Zeitung" of today republishes from the "Cape Times" of the $16^{\text {th }}$ Ultimo, the Correspondence which has passed between Her Majesty's Government and Sir Hercules Robinson, ${ }^{15}$ respecting the German Protectorate of Angra Pequēna and the extension of British Authority on the West Coast of Africa.

By way of comment, the "Nord Deutsche Allgemeine" reproduces an article from the "National Zeitung" of the $12^{\text {th }}$ instant, on the same subject of which a translation is herewith enclosed. ${ }^{16}$

The feeling in Germany respecting these Colonial Questions is so strong, as Your Lordship is aware, that the publication of the above-named correspondence can only tend to confirm the General suspicion that England opposes the Colonial Aspirations of the people of Germany, and the impression of disappointment it must produce will be painful and lasting throughout Germany.

\section{FO 64/ro5I: Gharles S. Scott to Earl Granville, No 23I, Berlin, 25 August 1884}

[28 August by post; For: The Queen / Gladstone; X, Ch.W.D. [Charles Wentworth Dilke]; Qy: 'Any comments to Mr Scott?', T.G.S. [Thomas G. Staveley]; 'Answered', 4 September]

Report detailing the death of Ampthill; sympathies of German imperial family and press

I have the melancholy duty to report to Your Lordship the death of Her Majesty's Ambassador, Lord Ampthill, which took place this morning at eleven o'clock at his country residence at Potsdam.

\footnotetext{
${ }^{15}$ Telegram from Lord Derby to Robinson, dated I5 July I884. This stated that the British government was 'not in a position to oppose' German protection for German subjects, but 'where no British jurisdiction already exists' it 'will be prepared to proclaim under British protection and authority any other places $[\ldots]$ to which British subjects have claims'.

${ }^{16}$ Enclosures: article 'Politischer Tagesbericht' in Norddeutsche Allgemeine Zeitung and translation, both dated I8 August I884.
} 
His Excellency although for some time past in delicate health had apparently recovered strength and spirits from the country air, and even so late as Tuesday last transacted business at the Ministry for Foreign Affairs, and neither complained of nor exhibited any unusual symptoms likely to create uneasiness on his account. - It appears that on returning to Potsdam in the evening severe pains set in in the region of the liver, similar to those from which His Excellency suffered in the beginning of last May. Medical assistance was at once called in but it was not until Thursday morning that he was so unwell as to be quite unable to attend to business, and accordingly requested me to act for him, expressing a hope that he might be sufficiently recovered to come up to town on Saturday to sign the despatches. Lady Ampthill having expressed more uneasiness on Friday I went to Potsdam on Saturday and found that Lord Ampthill had suffered greatly during the night, and was very weak; the illness however seemed to be running a favourable course and no serious alarm was entertained.

His Excellency was so far recovered in the morning as to be able to take notice of some private communications which I had brought him and to give me his instructions through Lady Ampthill. On Sunday morning the accounts were more favourable, but in the evening what proved to have been an abscess burst, perforating the intestines and violent vomiting ensued, causing serious alarm. Her Majesty the Empress ${ }^{17}$ despatched her personal physician ${ }^{18}$ to assist Lord Ampthill's medical attendant, ${ }^{19}$ and he then pronounced the case a dangerous one, but this news only reached the Embassy at Io this morning, and on arriving at Potsdam we found our worst fears realised.

His Excellency, after six hours of almost complete absence of pain and, except during a slight interval in full possession of his consciousness, passed peacefully away at I oclock $[s i c]$ in the presence of Lady Ampthill and all his family.

Their Imperial Majesties had been unremitting in their enquiries ever since the commencement of the illness, and The Empress, arriving at the villa to make personal enquiries, a few minutes after its fatal termination had herself assisted into the house from the carriage and was the first to offer her sympathy to Lady Ampthill. - The Emperor who has been deeply affected by this sad event has expressed to Colonel Swaine his concern at the loss of a respected personal friend.

\footnotetext{
${ }^{17}$ Augusta.

${ }^{18}$ Carl Velten.

${ }^{19}$ Name not traceable.
} 
From every quarter private and Official expressions of sympathy have been presented both at Potsdam and at Her Majesty's Embassy, and the Press, of every shade of opinion testifies to the great loss which the two countries have sustained by the death of a diplomatist, whose unremitting efforts have during i3 years been directed to strengthening and maintaining the friendly relations between the two Governments.

I lost no time in officially communicating the melancholy intelligence to the Imperial Minister of Foreign Affairs, and in requesting His Excellency to permit me to carry on the necessary official communications of the Embassy with him until Your Lordship's instructions have been received.

Dr Busch, in the absence of Count Hatzfeld, who left Berlin today has promptly replied, agreeing to my proposal and assuring me of the deep sympathy which the Imperial Government feel in the loss which The Queen has sustained of so eminent a diplomatist as Lord Ampthill.

Lady Ampthill who is prostrated with grief, has expressed a desire that His Excellency's remains should be conveyed to England, but no arrangements will be concluded until the arrival of Colonel Villiers and other members of the family who are expected tomorrow. In the meantime there appears to be a very general desire here to pay some public mark of respect to His Excellency's Memory.

\section{FO 64/ro5I: Gharles S. Scott to Earl Granville, No 242, Berlin, 30 August 1884}

[Received i September by Messenger Powell. For: The Queen; X, Ch.W.D. [Charles Wentworth Dilke]; Qy: 'Mr Scott to take an opportunity of expressing satisfaction of H.M. Government, at the marks of respect \& affection thus shewn by the Emperor; the Crown Prince \& Princess and the Royal Representatives of Foreign Countries on the occasion referred to.' T.G.S. [Thomas G. Staveley]; G[ranville]]

Ampthill's remains sent from Potsdam to England; ceremony attended by diplomatic corps, the emperor and royal family

I have the honour to report that the Remains of Lord Ampthill, as stated in my telegram $\mathrm{N}^{\mathrm{O}}$ I I of the $27^{\text {th }}$ instant, left Potsdam yesterday morning for England.

On the afternoon of the preceding day His Imperial and Royal Highness the Crown Prince, ${ }^{20}$ who only returned that morning from South Germany, paid a visit of condolence at the villa, and

\footnotetext{
${ }^{20}$ Friedrich Wilhelm.
} 
placed with his own hands two wreathes [ sic] on the Bier, as a last mark of the affections felt for Lord Ampthill by His Imperial Highness and by the Crown Princess ${ }^{21}$. Wreaths were also sent by Her Majesty the Empress, ${ }^{22}$ and by Their Royal Highnesses the Princess Christian of Sleswig Holstein, ${ }^{23}$ Princes William and Henry of Prussia and the Princess of Saxe Meiningen. ${ }^{24}$

By His Majesty's orders a Royal Hearse, followed by two of the Royal Carriages in full state was sent early yesterday morning to convey the Coffin from the Villa to the Potsdam Railway Station, and every attention and mark of respect, compatible with Lady Ampthill's wish to maintain throughout the strictest privacy, was paid to His Excellency's memory. At the Potsdam Station Prince Radziwill and Count Königsmark were in waiting to represent the Emperor and Empress.

On the arrival of the train at Charlottenburg at about 7.30 a.m., the funeral carriages were detached, and waited there for the morning Express Train to Flushing.

The Ambassadors of Italy, Austria-Hungary and France, ${ }^{25}$ the Staff of Her Majesty's Embassy, and the whole of the Diplomatic Body now in Berlin were present at the Charlottenburg Station, as well as $\mathrm{D}^{\mathrm{r}}$ Busch, Acting Minister for Foreign Affairs, and Count Radolinski, Comptroller of the household of His Imperial and Royal Highness, the Crown Prince.

\section{FO 64/1ro4: Gharles S. Scott to Earl Granville, No 307, Berlin, 9 October 1884}

Received I3 October by Messenger Wynter. Extends telegram No 19. Copy to: Colonial Office; Print (South West Coast of Africa); G[ranville]]

Appeal to German minister for foreign affairs concerning Lüderitz's actions in Angra Pequena

On receipt of Your Lordship's telegram $\mathrm{N}^{\mathrm{O}} 25$ of yesterday I at once called on the Acting Minister of Foreign Affairs, and made a strong representation to His Excellency in the sense of Your Lordship's instruction in regard to the action of $\mathrm{Mr}$ Lüderitz at Angra Pequeña requesting that instructions might be sent to that Gentlemen to desist from advancing claims to the possession of the

\footnotetext{
${ }^{21}$ Victoria.

${ }^{22}$ Augusta.

${ }^{23}$ Helena.

${ }^{24}$ Augusta (Saxe-Meiningen).

${ }^{25}$ Edoardo de Launay, Emmerich Graf Széchényi and Alphonse Chodron de Courcel.
} 
islands lying off the West Coast of Africa between $26^{\circ}$ South Latitude and the Grange River, and from interfering with those islands or with the British Lessee. ${ }^{26}$

Dr Busch at once admitted that these islands were the ten referred to by Baron Plessen, ${ }^{27}$ as claimed by the Government of the Cape Colony to which the German Protectorate would not extend, and promised to attend to my representation at once and let me know the result as soon as possible.

His Excellency said, that as there was at the present moment no German Consul or Authority within easy access to Angra Pequeña, $\mathrm{M}^{\mathrm{r}}$ Lüderitz had probably acted without full knowledge of the latest views and intentions of the Imperial Government in regard to the recently established Protectorate.

\section{FO 64/1145: Edward Malet to Earl Granville, Very Confidential, No 33I, Berlin, 23 October 1884}

[Received 27 October by Messenger Leeds. For: The Queen / Prince of Wales / Gladstone / Circulate / Approve Language / Copied for Print (South West Coast of Africa); Query: Copy to Colonial Office - very confidential / Embassies - very confidential; Qy: 'Mr Anderson to see'; G[ranville]]

\section{Conversation with Bismarck concerning Anglo-German relations and German colonization}

With reference to my Despatch $\mathrm{N}^{\mathrm{o}} 36$, Africa, of this date, I have the honour to inform Your Lordship that I took the opportunity of Prince Bismarck's visit to me this morning to endeavour to speak to His Highness on the general question of the relations between England and Germany, and stated to his Highness that I was authorised by Your Lordship to say that it would give you great satisfaction to be fully informed of his Highness' views, and to act with His Highness in the most friendly spirit on the points on which the common interest of the two countries were engaged.

His Highness replied that he was sure that if he had only to deal with Your Lordship these friendly relations would easily maintained,

\footnotetext{
${ }^{26}$ The coastal area of Angra Pequena (see n. 13 in this section) was proclaimed a German protectorate on 7 August I884. On 6 October Lüderitz claimed that the hoisting of the German flag on mainland Africa meant that the islands in question came into German possession, and called upon the lessee to vacate them.

${ }^{27}$ Busch was probably referring to the German chargé d'affaires' interview with Earl Granville at the Foreign Office on 20 September. The ten islands (Ichaboe, Long Island, Seal Island, Penguin Island, Halifax, Possession Island, Albatross Rock, Pomona, Plum-pudding and Roast Beef [Sinclair] Island) had been formally annexed to the Cape Colony in 1874 .
} 
but that unfortunately Your Lordship did not rule the Colonial Office, and that there he met with a spirit of disregard for all but the exclusive interests of England. He said that the Colonial Office, although it was aware of the aspirations of other countries, and of the advantages which such aspirations must afford to civilization, treated each question, as it arose, within the narrow circle of English commercial advantage, and ignored the larger view of friendly relations and benefit to the world.

I observed to His Highness that latterly this had really been not the case; that Her Majesty's Government had recently, in the various questions which had come up for settlement with Germany, done all in their power, consistently with State rights and obligations, to meet His Highness' wishes; and I referred notably to the question of New Guinea, where we had restricted our protectorate simply in consequence of his Highness's observations. ${ }^{28}$

Prince Bismarck went on to say that the Colonial question in Germany had taken a hold on the sentiment of the German People greater than that to which it was entitled, but that for the moment there was no restraining it. He said that the Emperor Napoleon on one occasion, ${ }^{29}$ speaking about an ambition of the French which had recently taken shape, that the Mediterranean should approach the condition of a French Lake, had observed that the French, who did not shine as a nation by their horse-riding, nevertheless were always endeavouring to excel in a circus, and considered the superiority of Franconie as a legitimate ambition. So, though they were mighty in arms on land, and might have been satisfied with that, they must needs now prove their powers at sea, for which they had never shewn great aptitude.

Something of the same sort, said Prince Bismarck was occurring in Germany at present with regard to colonisation, and the sentiment had so entangled itself with the electioneering question, that it had to be treated with greater deference and circumspection than in the beginning had appeared to be necessary.

I should add, that although Prince Bismarck made use of no words which could wear the appearance of being designed to attenuate his recent attitude on the colonial and other questions towards Her Majesty's Government, his manner was eminently friendly and

\footnotetext{
${ }^{28}$ On I9 September I884 Scott informed the German government of the British intention to extend British authority in New Guinea; on 9 October Scott communicated the British restriction to the south coast; on 6 November i884 the Territory of Papua, the south-eastern part of New Guinea, became a British protectorate.

${ }^{29}$ Bismarck was referring to Louis-Napoleon Bonaparte's speech at Marseille on 26 September 1852 .
} 
cordial, and gave me the impression that that which I may be allowed to call his past ill-humour has been rather the result of political calculation than personal sentiment.

This, however, increases the gravity with which it should be regarded, as it may prove to be a carefully prepared excuse for a more complete understanding with France than we are aware of.

\section{FO 64/1052: Edward Malet to Earl Granville, No 407, Berlin, 27 December 1884}

[Received 29 December by Mr Taylor. Immediate: Print - Egypt (Finance) / Embassies; G[ranville]]

\section{German government's policy towards Egyptian debts; public opinion increasingly anti-English}

With reference to Your Lordship's Despatch $\mathrm{N}^{\mathrm{o}} 3 \mathrm{I}^{\mathrm{A}}$ of the $\mathrm{Io}^{\text {th }}$ Instant, recording a Conversation with Count Münster on that date, in which Your Lordship urged upon His Excellency the pressing character of the question of Egyptian Finance, I have the honour to inform Your Lordship that I have lost no opportunity of speaking in the same sense here.

I regret to say that I have found no disposition on the part of the German Foreign Office to use any pressure on other Powers to give a speedy answer to the proposals of Her Majesty's Government, nor has it pronounced its own opinion with regard to them..$^{3 \circ}$

It regards the question as one to be settled in the first instance between England and France, and I am led to believe that any agreement which is come to by them will be followed by the adhesion of Germany[,] Austria and Russia.

On the other hand, if no understanding is arrived at with France, Germany and the Powers which accept her lead are certain not to consent to English proposals.

There remains to be considered the attitude which Germany would assume in the event of the failure of the present negotiations and the consequent necessity of England acting without European sanction.

\footnotetext{
$3^{30}$ The British proposal, based upon a modification of the Law of Liquidation of July I880, provided details for the financial settlement between Egypt and its international creditors. It was submitted to the German government on 29 November i884. In his conversation with the German ambassador to London, on Io December, Earl Granville stated that further delay would render the proposal insufficient; therefore he hoped for a favourable reply at an early date. The British - as well as the German - negotiating position on the Egyptian question was largely affected by the fact that two-thirds of the debt was held by French creditors. The British role in Egypt - de facto a British protectorate since I882 was also affected by the Mahdist revolt against Egyptian rule in Sudan.
} 
Public feeling in Germany has for the last six months been encouraged in the direction of hostility towards England; the friendly attitude which we have assumed on the Colonial question has effected no appreciable change..$^{3}$ Our manifest desire to meet the wishes of Germany as far as is compatible with our rights and obligations have met with so little response that it would seem as though the German Foreign Office were deliberately maintaining ill-feeling towards us for some ulterior purpose after the original cause has been obliterated.

It is not necessary to be possessed of an unduly suspicious nature to suspect that there is a direct connection between the maintenance of this irritation on the Colonial question and the future policy of the German Government towards England in case the Egyptian question enters upon a more acute phase.

The way, at least, is thus prepared for a coalition of the Great Powers, with the exception of Italy, against us, which would not have been possible a year since. At that time German public feeling would have sided with England in such an emergency, and the coalition, including Italy, would have been against France.

As matters are at present, probabilities point to Germany, Russia, Austria and France being arrayed against us, if we do not come to terms with the last named Power; and I fear that our exceeding weakness in Egypt, in consequence of the expedition to Khartoum ${ }^{32}$ has been taken into account in calculating the means which we should have at our disposal to withstand such a coalition.

\section{FO 64/1146: Edward Malet to Earl Granville, Confidential, No 45, Berlin, 24 January 1885}

[Received 26 January by Messenger Callander. Print (Pacific)]

Conversation with Bismarck regarding German colonial policy

With reference to my Despatch $\mathrm{N}^{\mathrm{o}} 55$, Africa of today's date, I have the honour to inform Your Lordship that, after I had finished reading to

\footnotetext{
${ }^{31}$ Malet is referring to Britain's concessions in colonial matters, including the formal recognition (on 22 September 1884) of German policy with regard to South West Africa (in particular, the declaration of Angra Pequena (Lüderitz Bay) as a German protectorate) and her conduct during the Berlin West Africa Conference, which opened on 15 November I884 and aimed to regulate European trade and colonization in Africa.

$3^{2}$ The British Nile Expedition was sent to relieve General Gordon and his troops at the besieged city of Khartoum, Sudan. However it arrived on 28 January 1885, two days after the city had fallen to Mahdist Sudanese forces.
} 
Prince Bismarck Your Lordship's Despatch $\mathrm{N}^{\mathrm{o}} 29$ African of the $20^{\text {th }}$ Instant, he spoke to me at length on the circumstances leading to the present political estrangement between the two countries.

He said that at every point at which Germany had endeavoured to found a Colony England had closed in, making new acquisitions so as to restrict Germany's power of expansion. He proceeded to the question of New Guinea, and he asserted that he had understood from $\mathrm{M}^{\mathrm{r}}$ Scott's Note of the $9^{\text {th }}$ October that we had accorded him free hand with regard to the north; that to his understanding, the words "without prejudice to any territorial question beyond these limits" gave him such liberty. ${ }^{33}$

I argued with the Prince on both points to the effect that we had not extended our Protectorates in the order stated; that we had on the contrary, been going even to the Cameroons before we were in any way aware that Germany intended to establish a Protectorate there ${ }^{34}$ that in regard to New Guinea, when first Count Münster had spoken about it, Your Lordship had informed him that steps towards annexation had already gone farther than was known; as to the words, "without prejudice", ${ }^{35}$ conveying such a meaning as the Prince attached to them, I assured him that the only meaning which could be attached to them in the English language was that the question with regard to the rest of New Guinea remained as it was before, and that, in any case, the words were followed by the statement of opinion that questions regarding territories beyond those which we had annexed should be dealt with diplomatically. The Prince persisted that he had understood the words in an entirely different sense, and had considered that he was free to annex that which we had not annexed.

He proceeded to say that in order to show me how different were our relations only a year ago, and how much he had desired that the good relations then subsisting should continue, he would read me a Despatch which he had addressed to Count Münster on the $5^{\text {th }}$ of last May.

He must believe that Her Majesty's Government had entirely failed to appreciate the importance which his Government attached to the Colonial Question, as he could not suppose that, if Your

\footnotetext{
${ }^{33}$ For Scott's note of 9 October 1884 and the British protectorate in New Guinea see n. 28 in this section.

${ }^{34}$ The German protectorate of Cameroon was declared by Gustav Nachtigal on I4 July I884.

${ }^{35}$ In his conversation with Münster of 8 August I884 Granville stated that 'the extension of some form of British authority in New Guinea [...] will only embrace that part of the island which specially interests the Australian colonies, without prejudice to any territorial questions beyond those limits'.
} 
Lordship had understood it, the successive annoyances to which Germany had been exposed would not have been averted.

This Despatch of the $5^{\text {th }}$ May to Count Münster was a very remarkable one.

It stated the great importance which the Prince attached to the Colonial question, and also to the friendship of Germany and England.

It pointed out that in the commencement of German Colonial enterprise, England might render signal service to Germany and said that for such service Germany would use her best endeavours in England's behalf in questions affecting her interests nearer home. It pressed these considerations with arguments to show the mutual advantage which such understanding would produce, and it then proceeded to instruct Count Münster to say that if it could not be effected the result would be that Germany would seek from France the assistance which she had failed to obtain from England, and would draw closer to her on the same lines on which she now endeavoured to meet England. The Despatch was a long one, and the Prince read it to me in German, but the above was the gist of it.

Prince Bismarck went on to say that, not being satisfied with the result, and attributing it in part to the Ambassador not having stated the points with precision, he sent his son, Count Herbert Bismarck, to England, ${ }^{36}$ in the hope that he might succeed where Count Münster had failed; but that he, unfortunately, had only succeeded in obtaining those general friendly assurances of good-will which were of little value in the face of subsequent occurrences.

The Prince then read to me a Draft of a Despatch which he is now sending to Count Münster, ${ }^{37}$ in which he takes up a remark, which His Excellency attributes to Your Lordship, in a report ${ }^{3^{8}}$ on the Egyptian Question, to the effect that the attitude of Germany on the Colonial Question makes it difficult for Your Lordship to be conciliatory on other points. ${ }^{39}$

The Prince next reverted to what he termed our closing-up system, and he mentioned Zululand, observing that the Boers claimed a cession dating from 1840 with King Panda. ${ }^{\circ}$

\footnotetext{
$3^{6}$ Talks between Herbert von Bismarck and Earl Granville took place on I4, I7, and 22 June 1884 .

${ }^{37}$ Bismarck to Münster, 24 January I884 (sent on 26 January).

${ }^{38}$ Münster to Bismarck, 2I January I885.

${ }^{39}$ For the Egyptian question see n. 30 in this section.

${ }^{40}$ Bismarck was probably referring to the cession of territory to the Natal Boers - in exchange for the support of the proclamation of Mpande as king of the Zulus in I840. Another cession to the Boers - land on the border between the Zulu Kingdom and the Transvaal Republic - took place in 1854 .
} 
I said that I feared the Prince's good faith had been imposed upon, as no such State as the Transvaal had existed at that date ${ }^{41}$ and that the only Boers who could have obtained a cession of territory, if such existed, were our own subjects. The Prince replied that it was not a question which a law-suit would settle.

I then said to the Prince that the whole situation was undoubtedly a very unsatisfactory one, and that it gave me great pain, as it had been my hope and endeavour, under instructions from Your Lordship, to bring about a more cordial understanding between the two Powers; that I knew that it had never been the intention of Her Majesty's Government to thwart the Colonial aspirations of Germany, and that in my opinion, our action had repeatedly shewn this desire; but I said that it would be impossible for us to act so as to meet his wishes, even where it was easy for us to do so, unless we knew what those wishes were, and I therefore begged him to tell me what now, at this moment, he wanted: was it the parts of New Guinea which we were now annexing? Was it Zululand? I said that the knowledge of his wishes, whatever they might be, was better than that we should go on mutually acting in the dark, and consequently running against each other.

The Prince replied that the understanding which he had arrived at with France ${ }^{42}$ in consequence of his failure to come to one with us put it out of his Power to take up the question now, as he had expounded it to us in May. The long conversation came to an end, by his saying that he had been anxious to explain to me the series of circumstances that had preceded the present phase of the political relations between the two countries, which he was sure I must regret as much as he did.

\section{FO 64/1149: Gharles S. Scott to Earl Granville, No ro7, Berlin, 4 March 1885}

[Received 6 March by post. For: The Queen / Gladstone / X, Ch.W.D. [Charles Wentworth Dilke]/ Print (Pacific) / Consular Department; G[ranville]]

German press reactions to revelations in Blue Books about colonial negotiations between Britain and Germany

I have the honour to enclose, with translations, copies of two further Articles directing somewhat violent charges against her Majesty's

\footnotetext{
${ }^{4 \mathrm{I}}$ The South African Republic (Transvaal) was founded in 1852.

$4^{42}$ Bismarck was referring to Germany's approval of the French scheme of 8 January I885 to financially reorganize Egypt, and the French support of the Russo-German request to send representatives to the Public Debt Commission (Caisse de la Dette Publique), which supervised the repayment of Egyptian debts to foreign creditors.
} 
Government for alleged indiscretions committed in the publication of the recently issued Parliamentary Papers on questions under negotiation between the two Governments. ${ }^{43}$

These Articles appeared in the semi-official Norddeutsche Zeitung of last night and this morning, and like their predecessor in yesterday's edition of the same paper bear the impress of official inspiration.

The first Article is devoted to Your Lordship's Note to Count Münster of the $2 \mathrm{I}^{\text {st }}$ ultimo on the subject of recent occurrences in the Cameroon Protectorate, and the charges preferred against English officials by the German Government, which the Article asserts have in the Note referred to met with a rude dismissal at Your Lordship's hands, - by the notification of counter claims against the German Government on the part of English Subjects for losses occasioned during the same occurrences, of which, it says, it is impossible Your Lordship could have received sufficient proofs at the time the Note was penned. ${ }^{4}$

The Article concludes by referring, as a parallel case, to the alleged Bombardment and destruction of Alexandria by Her Majesty's Naval forces, ${ }^{45}$ and the losses thereby occasioned to German and other subjects; and says that England seems to deal out unequal measures in regard to the two cases, asserts that a country pledged for international obligations; and instead of taking upon herself the compensation of the Alexandria losses, throws it upon the Bondholders; but it states its conviction that Germany will insist on the proceedings of England in Egypt and those of Germany in the Cameroons being considered on the same lines of justice.

The second Article deals with Sir E. Malet's Despatch $\mathrm{N}^{\mathrm{o}} 45$ to Your Lordship of the $24^{\text {th }}$ January, ${ }^{46}$ and states that it's publication constitutes the gravest of all the indiscretions, that the revelation to the public of observations made by Prince Bismarck to Her Majesty's Ambassador in the course of a confidential conversation which was prompted by the footing of personal friendship on

\footnotetext{
${ }^{43}$ Enclosures: extracts from Norddeutsche Allgemeine Zeitung, 3 March 1885 and Norddeutsche Allgemeine Zeitung, 4 March 1885 and corresponding translations.

${ }^{44}$ Charges were brought against British traders and the acting British vice consul for stirring up the natives; against Captain Campbell and Consul Hewett for international discourtesy and disrespect towards the German authorities; and, lastly, against English missionaries, who were suspected of giving aid to rebellious natives. These German measures led to the destruction of English mission buildings and storehouses in Hickory Town.

45 The bombardment of Alexandria by the British Mediterranean Fleet (II-I3July I882) took place during the Anglo-Egyptian War.

${ }^{46}$ Malet's No 45 (see pp. 44-47) was published in Further Correspondence respecting New Guinea and Other Islands in the Western Pacific Ocean, in February 1885.
} 
which the Chancellor stood to His Excellency, and the late Lord Ampthill, will in the future preclude the possibility of similar confidential intercourse between the Statesmen of the two Governments.

The tone of this Article is especially significant in the suspicion thrown out that the publication of this Report was meant to sow the seeds of distrust between France and Germany, and in the strange rendering of Sir Edward Malet's very clear request to know what were the precise Colonial aims of Germany, into an attempt to loosen the political relations of Germany with France.

\section{FO 64/II49: Gharles S. Scott to Earl Granville, No I12, 7 March 1885}

[Received 9 March by Messenger Newton. For: The Queen / X, Ch.W.D. [Charles Wentworth Dilke]; Qy: Print dispatch and extract ${ }^{47}$ for inclusion / Copy to Colonial Office / Print (Pacific); G[ranville]]

Debates on colonial policy in Reichstag and Prussian Landtag; Social Democrats defend English position

With reference to my despatch No: Ioo of the $28^{\text {th }}$ ultimo I have the honour to transmit a summary of the proceedings on the German Reichstag and Prussian Landtag during the past week, ${ }^{48}$ which has been carefully drawn up by $\mathrm{M}^{\mathrm{r}}$ Gosselin, and to which I would venture to invite special attention as the Reichstag has this week been almost exclusively occupied with the votes for Colonial purposes on which the Government lay much stress, and some very interesting and remarkable speeches were delivered.

One of these, that of the Imperial Chancellor, I have already had the honour to transmit in full text and translation to Your Lordship in my despatch no: 104 of the $3^{\text {rd }}$ instant. ${ }^{49}$

The remarks of M. de Kusserow, the Representative of the Department of the German Foreign Office specially occupied in Colonial questions, are interesting as explaining among other matters

\footnotetext{
${ }^{47}$ Extract from Granville to Scott, No 96 A, Secret, 9 March 1885 (on his conversation with Herbert von Bismarck about his father's speech in the Reichstag).

${ }^{48}$ Enclosures: summary of Reichstag proceedings, 2-6 March, by Mr Gosselin, 7 March I885; summary of Landtag proceedings 28 February-6 March, by Mr Gosselin, 7 March I885.

${ }^{49}$ In his speech of 2 March 1885 Bismarck deplored the lack of support for his colonial policy and criticized the obstruction of his endeavours by the British press and government. He also denied encouraging Earl Granville to annex Egypt.
} 
the genesis and development of the new Colonial movement in South Africa, and the South Sea, and the mission of $\mathrm{D}^{\mathrm{r}}$ Nachtigal. ${ }^{50}$

The Government, as Your Lordship will perceive, carried the Cameroon vote, but were defeated on the vote for increasing the Consular salaries at Samoa and Corea. ${ }^{51}$

It is unfortunate that the part of defending England against certain attacks in the course of this debate should have been taken up solely by the Social Democratic member, Herr Liebknecht, and by the Free Trade Deputy Herr Richter, both of them inveterate opponents of the Imperial Chancellor as well as of his Colonial policy.

This may possibly account for some of the displeasure which, strange to say, was manifested by the factions sitting on the right side of the house at Herr Richter's quotation of the Times article ${ }^{52}$ advocating the cultivation of friendly relations between England and Germany.

\section{FO 64/1077: Charles S. Scott to Earl Granville, Secret, No I6I, Berlin, I I April 1885}

[Received I3 April by Messenger Cavendish. For: The Queen / Mr Gladstone / Cabinet; G[ranville]]

German public and political views on the Afghan border crisis; financial markets affected by Russo-British tension; conversations with Hatzfeld and Turkish ambassador

The German Government and public are following with intense interest the action of the English and Russian Governments in regard to Central Asia.

Already on the $7^{\text {th }}$ instant before receiving Your Lordship's Secret telegram of that day I ascertained privately that the general purport of the Russian reply to Your Lordship's despatch of the $13^{\text {th }}$ March and of the light in which it was regarded by the English Cabinet was known to Prince Bismarck and in certain other influential quarters here, and that in spite of the serious turn which the negotiations seemed to be now taking Prince Bismarck could not bring himself

\footnotetext{
${ }^{50}$ Kusserow, on 2 March 1885 , stated that the German government's policy was 'to follow with assistance private undertakings'. On Nachtigal's mission see nn. I2 and 34 in this section.

${ }^{{ }^{\mathrm{I}}}$ The Reichstag passed the supplementary budget for the German protectorates in Africa on 2 March 1885; the recommendations concerning the consulates in Corea and Samoa were rejected on 4 March.

${ }^{52}$ On 4 March Richter (after being informed by a telegram from the Wolff News agency) referred to the Times editorial of that same day.
} 
to believe that they would end otherwise than in a peaceful arrangement between the two Governments. ${ }^{53}$

In the course of the following day a rumour to the effect that the Russian troops had advanced and occupied Pendjeh had been received by one influential Banking house here, and a slight fall took place on the Bourse in Russian securities which had already been sensibly affected by the news that a tax was to be levied on the coupons of the later Russian loans, but the German Foreign Office had received no intelligence tending to confirm it. When the official telegram of the Engagement was received from St. Petersburgh the following day, a panic, such as has not been known for years, ensued on the Bourse, Russian securities falling five and English Consols one per cent.

Considering that Russian Stock to the extent of I believe fifty millions sterling are held in Germany alone, the interest of this country in the maintenance of a peaceful policy by Russia is self-evident, and this fact is, I am informed, not lost sight of by the German Chancellor who is as anxious for a peaceful solution of the present difficulty as Her Majesty's Government can be. I am privately informed that even so late as last night the Prince professed a confident hope that serious conflict would be avoided. The information which he had received from St. Petersburgh as well as from London shewed the two Governments to be equally animated by an ardent desire for peace and that they were approaching the discussion of a most serious incident, in regard to which the reports from their respective officials on the spot sensibly differed, in a moderate and statesmanlike spirit.

I may add that Count Hatzfeld spoke to me yesterday in a similar sense, and that on my shewing him the report of $\mathrm{M}^{\mathrm{r}}$ Gladstone's statement in the House of Commons on Thursday which I had just received by telegraph from Your Lordship, ${ }^{54}$ His Excellency expressed his sincere appreciation of its calm and dignified tone and said that it strengthened his hopes of a peaceful solution, as the same spirit seemed to prevail at present at $S^{t}$ Petersburgh, and he believed the Russian Government had already made more acceptable proposals to Your Lordship..$^{55}$

\footnotetext{
${ }^{53}$ The Russian reply to the British memorandum on the Afghan border question of I3 March was dated 29 March. The British proposal for a frontier in north-west Afghanistan was rejected and the Russians insisted on their original proposal made in January that year. The British government deemed it impossible to proceed on this basis and on 30 March Russia occupied the Panjdeh district, which belonged to the Emirate of Afghanistan.

${ }^{54}$ On 9 April I885 Gladstone informed the House of Commons about the Afghan frontier negotiations with Russia, and in particular his knowledge of the Panjdeh incident.

${ }^{55}$ Hatzfeld was probably referring to new proposals which had been sent by telegraph to the Russian ambassador to London, Baron Staal, on 7 April 1885 which were communicated to the Foreign Office on 8 April.
} 
His Excellency admitted the possibility of the Russian Generals having exceeded their instructions, though he could not avoid suspecting that the Afghans must on their side have given some provocation.

I have been privately informed in strict confidence by the same gentleman ${ }^{56}$ to whom I was indebted for the information contained in my despatch $\mathrm{N}^{\mathrm{O}}$ I45 Secret of the $28^{\text {th }}$ ultimo, that on his making a suggestion to Prince Bismarck that his powerful influence might now be exerted with good effect at $S^{t}$ Petersburgh to induce the Russian Government to offer some satisfaction to England for an incident for which the excessive military ardour of her generals seemed to be mainly responsible, the Prince replied that it was entirely impossible for him to take the slightest action in this sense: - His feeling for England was more friendly now than it had ever been, this fact was known at $\mathrm{S}^{\mathrm{t}}$ Petersburgh, and any step he might take there was sure to be misconstrued. Up to the present moment he had not received a hint either from $S^{t}$ Petersburgh or London that his good offices were desired, but they would be gladly given on the first intimation of such a desire from the two Governments. He still looked forward to a peaceful issue of direct negotiations between the two Governments without the necessity of help from a third party, and in the meantime his policy was and would continue to be one of absolute neutrality. He was satisfied of the sincere desire for peace of the Emperor of Russia and his Government and also of Mr Gladstone and his colleagues but his whole efforts would be directed to securing by every means in his power that if hostilities did unhappily break out between those two powerful nations, they should not endanger the peace of the rest of Europe but be localized as strictly as possible.

With this view I am positively assured on authority entitled to considerable credit that very strong pressure is, at the present moment being put by Prince Bismarck, and at his instigation by the Austrian Government on Turkey to hinder any act, engagement or attitude on her part which might eventually involve the East of Europe in the conflict.

This action, I am assured is being taken not with any desire to hamper or paralyze the action of England in case of an Anglo Russian war, or to secure an unequal advantage to Russia in the struggle, but simply because the peace of Europe was a paramount necessity both for Germany and Austria who had entered into formal engagements at Skierniewicz ${ }^{57}$ to use their influence to keep Turkey

\footnotetext{
${ }^{5}$ Name not traceable.

${ }^{57}$ Malet is referring to the three emperors' meeting at Skierniewice from ${ }^{1} 5^{-17}$ September 1884.
} 
quiet on the slightest symptom of her adopting an attitude likely to endanger that peace.

I am the more inclined to attach credit to this information since a conversation which I had with the Turkish Ambassador ${ }^{5^{8}}$ this afternoon. His Excellency took the opportunity of a visit which I paid to him to discuss the general political situation and to express his conviction that although he was inclined to believe matters would be patched up at present between us and Russia, a conflict must eventually ensue between the two Powers in Central Asia, and he then repeated to me at great length his views of the policy which had led up to the present situation[,] the advantages which we had on several occasions let slip of meeting a Russian advance with a preponderance of chances in our favour and ended by an opinion that in view of a strong coalition of the European Powers anxious to secure the Peace of Europe by every means in their power, the task which we should eventually have to undertake was becoming every day a more difficult one.

\title{
FO 64/1077: Edward Malet to Earl Granville, Secret, No 205, Berlin, 7 May 1885
}

\author{
[Received in May. Extender Telegram No 34; X; G[ranville]]
}

Conversation with Bismarck on matter of German arbitration in relation to Anglo-Russian difficulties

I have the honour to inform Your Lordship's [sic] that I have enquired of Prince Bismarck whether, if the Governments of Her Majesty the Queen and His Imperial Majesty the Emperor of Russia were to ask his Imperial Majesty the Emperor to arbitrate, His Majesty would accept..$^{59}$

The Chancellor replied that he would immediately submit the point but that he was doubtful as to whether the Emperor could consent, or as to whether he himself could advise His Majesty to do so.

He stated that the position of Germany was extremely delicate, and should the result of the arbitration prove to be adverse to

\footnotetext{
$5^{8}$ Said Pasha Kurd.

${ }^{59}$ Anglo-Russian tensions revolved around the rivalry for supremacy in Central Asia, and in particular the Afghan border question (see previous dispatch). At the time of the dispatch it was proposed to the German Emperor to act as arbiter and judge whether Russia had departed from Nikolai de Giers' verbal assurances of i6 March (reported to Earl Granville by Edward Thornton on the same day) that Russian forces would not advance from their positions, 'provided the Afghans [...] do not advance or attack, or unless there should be some extraordinary reason $[\ldots]$, such as a disturbance in Penjdeh'.
} 
Russia, the ill-feeling which had been created by his policy at the Congress of Berlin might be kindled afresh. ${ }^{60}$ Should he be justified in risking this danger? He was of opinion that a sovereign of less prominence would be preferable and more especially His Majesty the King of Denmark on account of his consanguinity to the Royal Families of the two Countries. ${ }^{61}$

He remarked that in any case it would be desirable to delay the award of the arbitration until the delimitation of the frontier had taken place, lest its promulgation should wound susceptibilities and endanger the negotiations.

The Prince enquired of me what was the precise point on which arbitration was sought as much must depend upon the text and it was settled between us that he should not call upon His Majesty for a final reply until Your Lordship had furnished me with an answer to this question. He wished to know the text of the agreement of the $16^{\text {th }}$ March. ${ }^{62}$

I was able to reply to the Chancellor in general terms but I stated that I had not yet received instructions from Your Lordship as to the text of the matter to be submitted to arbitration.

I have the honor to request that Your Lordship will furnish me with precise instructions on these points.

The Chancellor and I agreed that, in case His Majesty declines, the proposal should be treated as "non-avenu",63, as another Sovereign might be disinclined to accept if it were known that the Emperor considered the matter too thorny a one to undertake, and that the conversation which had taken place between us was to remain secret.

\section{FO 64/1078: Charles S. Scott to Marquess of Salisbury, Confidential, No 29o, Berlin, 4 July 1885}

[Received 6 July by messenger. For: The Queen / Munich / Prince of Wales / Duke of Cambridge; S[alisbury]]

Bavarian press reports on Brunswick succession; Federal Council seeks to disqualify Ernst August's claims

In compliance with the instructions of Your Lordship's Despatch $\mathrm{N}^{\circ}$ 280 to Sir E. Malet of the $\mathrm{I}^{\text {st }}$ instant, I have the honour to return

\footnotetext{
${ }^{60}$ The Berlin Congress of 1878 aimed to settle territorial claims on the Balkans and restore the balance of power after the Russo-Turkish War of $1877-78$.

${ }^{6 r}$ Christian IX's first daughter Alexandra was married to Edward, Prince of Wales; his second daughter Dagmar (Maria Feodorovna) was Empress of Russia.

${ }^{62}$ Bismarck was referring to the Russian assurances of I6 March.

${ }^{63}$ French 'nul et non avenu': not having happened.
} 
herewith $\mathrm{M}^{\mathrm{r}}$ Macdonell's Confidential Despatch $\mathrm{N}^{\mathrm{o}} \mathrm{I} 5$ of the $\mathrm{I}_{5}{ }^{\text {th }}$ ultimo on the Action of Bavaria in the Brunswick Succession Question which was forwarded for His Excellency's perusal. ${ }^{6_{4}}$

With regard to the Comments of the Bavarian Press on the action of Prussia in proposing to the Federal Council to declare His Royal Highness The Duke of Cumberland disqualified from succeeding to the Crown of a Federal State of the German Empire, I would venture to remark that no apprehensions seem to be entertained here that the decision taken by the Federal Council in the Case of The Duke of Cumberland can by any possibility be used, as a precedent such as the Bavarian press seems to anticipate, for altering the legitimate order of succession in other States of the Empire. ${ }^{65}$ The position of the Duke of Cumberland is unfortunately a peculiar and essentially exceptional one. The State to the Crown of which His Royal Highness is heir presumptive has already recognized by treaty the Sovereignty of Prussia in Hanover, The Duke is understood to question it, and this is the ground on which, so far as is yet known, the Federal Council has expressed an opinion that he is disqualified from acting as Sovereign in the Federal Union, the members of which have mutually recognized the respective rights of the Confederate Sovereigns to the territories in virtue of which they act and vote in the Federal Council.

Prussia, it is argued, has as a directly interested Party a constitutional right to invite an opinion on this point from the Council, and the latter an equal right to give it. ${ }^{66}$

It is not likely that a similar pretext could be found for invoking the intervention of the Council in any of the Succession questions indicated in $\mathrm{M}^{\mathrm{r}}$ Macdonell's Despatch as possible to raise in the future.

\footnotetext{
${ }^{64}$ See MacDonell's dispatch of I5 June I885, pp. 473-475.

${ }^{6}$ After the death of the childless Duke Wilhelm on I8 October 1884, Ernst August, Duke of Cumberland and son of the deposed Georg V of Hanover, proclaimed himself Duke of Brunswick. On 2 July 1885, following the Prussian motion of I8 May 1885, the Federal Council declared the rule of Ernst August, who was next in the succession, to be incompatible with the principles of the treaties of August 1866 and November I87o, and the imperial constitution of 1871. The background to this was Prussian mistrust of Ernst August due to the latter's claim to the throne of Hanover, which had been annexed by Prussia in I866. On 25 October 1885, the Brunswick diet elected Prince Albrecht of Prussia as regent.

${ }^{66}$ The original motion of 18 May referred to Article 76 of the imperial constitution, according to which disputes between states of the confederation were to be settled by the Federal Council, at the request of one of the parties.
} 


\section{FO 64/1078: Charles S. Scott to Marquess of Salisbury, No 315, Berlin, 18 July 1885}

[Received 20 July by messenger. For: The Queen / Lord Iddesleigh / Prince of Wales / Duke of Cambridge; S[alisbury]]

Press coverage of the Brunswick succession

With reference to the various rumours which have recently appeared in the public press in regard to the probable solution of the Brunswick Succession Question, I have the honour to state that I have good reason for believing them to be all based on simple conjectures \& to have no foundation, as yet, in fact. ${ }^{67}$

The Norddeutsche Allgemeine Zeitung whose utterances are generally supposed to be more or less officially inspired, has lately commented in two leading Articles ${ }^{68}$ on the apparently irreconcilable sentiments expressed in the two letters of His Royal Highness The Duke of Cumberland written respectively to The Queen and the late Duke of Brunswick in $1878,{ }^{69}$ the purport of which, as reported in my Despatch $\mathrm{N}^{\mathrm{O}} 294$ of the $8^{\text {th }}$ instant, was communicated to the Brunswick Diet by the Minister of State ${ }^{70}-$ the one letter upholding His Royal Highness's claims to an eventual Succession in Hanover, while the other professed His readiness to respect in the event of his Succession in Brunswick all the treaties concluded by that State with Prussia \& other Federal States of the Empire.

The Norddeutsche Zeitung observes that the evident mental reservation with which The Duke of Cumberland wrote his professions to the late Duke of Brunswick is entirely in accordance with the known views of the Guelph political party, and adds that a Guelph Sovereign in Brunswick would naturally always remain a pretender to Hanover, consequently the ally of Prussia's enemies both at home and abroad, for this reason he would be unacceptable both to Prussia and to Germany.

Commenting on a statement in the Brunswick press ${ }^{71}$ that Prince Bismarck had in 1878 assured Lord Beaconsfield that no objection would be offered to the Succession of the Duke of Cumberland in Brunswick, provided that His Royal Highness formally renounced

\footnotetext{
${ }^{67}$ On the Brunswick succession question see n. 65 in this section.

${ }^{68}$ On I5 and I8 July I885.

${ }^{69}$ The letters in question are dated I8 September I878 (to Victoria) and I4January I879 (to Wilhelm).

${ }^{70}$ Hermann von Görtz-Wrisberg, on 30 June I885.

${ }^{71}$ The Norddeutsche Allgemeine Zeitung was referring to the Hannoversche Kurier.
} 
His claims to Hanover, and in reply to the charge that this assurance was difficult to reconcile with the statement of opinion in the Prussian Motion recently submitted to the Federal Council to the effect that even a renunciation by the Duke of his claims to Hanover would not render his position in Brunswick more acceptable to Prussia, The Norddeutsche says that, even if it should prove to be a fact that Prince Bismarck gave such an assurance in 1878 , it would not be inconsistent with his holding a different opinion in 1885 on reading the letters referred to and after The Duke of Cumberland had distinctly asserted, in reply to advice offered to him by His Relations, that he would never under any circumstance renounce his claims to an eventual succession in Hanover.

I should add that the German press had stated that on Lord Beaconsfield receiving the assurance referred to from Prince Bismarck, Her Majesty the Queen wrote to the Duke of Cumberland advising His Royal Highness to comply with the conditions specified by the Prince, and that The Duke's Letter to Her Majesty, a copy of which His Royal Highness had sent to the Duke of Brunswick, was his reply to the advice thus offered to him.

\section{FO 64/1079: Edward Malet to Marquess of Salisbury, No 388, Berlin, 5 September 1885}

[Received 7 September by messenger. For: The Queen / Lord Iddesleigh / St Petersburgh / Vienna; S[alisbury]]

\section{Account of expulsion of Poles from East Prussia}

The alleged wholesale expulsion of Poles from the Eastern Provinces of Prussia to which the Foreign Press is apparently devoting some attention is, I understand, taking place not as has been asserted, in virtue of any special decree, but of Police measures which the Prussian Government has a legal right to put in force in case of necessity. ${ }^{72}$

The Poles who have received notice to quit are of foreign, chiefly Russian and Austrian, nationality, who in recent years have, in gradually increasing numbers, been crossing the frontier and establishing themselves for purposes of trade on Prussian soil without acquiring

\footnotetext{
${ }^{72}$ On 26 March 1885 , the Prussian minister of the interior, Puttkamer, in his rescript to the Oberpräsidenten of the eastern provinces ordered all Russian subjects of Polish nationality who resided in Prussia illegally to be expelled. On 26 July this order was extended to all alien residents of Polish provenance, in particular Poles from Galicia. Altogether about 32,000 people were affected.
} 
German nationality. This appears to have been especially the case in the Province of Posen.

The object of the Government in trying now to check the movement by steps which in many cases will no doubt entail great individual hardship is to prevent the gradual denationalization of a German Province by an undue increase of a Polish element of foreign nationality.

As many of the Poles in question are of Jewish extraction whose business habits and pursuits are uncongenial to their German competitors, the Government is no doubt also acting in what it believes to be the commercial interests of their own subjects in the province in question.

I believe that neither the Russian nor Austrian Government has as yet questioned the right of this Government to inforce [sic] this Police measure, but that the former Government is acting in a similar manner in regard to Prussian Poles settled in the frontier province of Russia.

The expulsions appear to be taking place only after due notice has been given to admit of the sufferers making their necessary arrangements and the measure as far as I can learn is not an entirely general one but carried out with some degree of discrimination in regard to the particular cases selected.

\section{FO 64/1079: Edward Malet to Marquess of Salisbury, Secret, No 436, Berlin, 22 September $188_{5}$}

[Received 28 September by [Messenger] Taylor. For: The Queen / Cabinet; S[alisbury]]

Bismarck on leadership of Austro-German policy in the East

I asked Prince Bismarck today whether Germany or Austria took the lead in deciding questions of policy regarding the East. He replied that he left all minor questions to Austria, giving her free swing as long as the tranquillity of Europe was not endangered, but that if he saw that she was moving too quickly or without sufficiently foreseeing consequences he took the reins into his own hand and was able to hold them.

\section{FO 64/1079: Edward Malet to Marquess of Salisbury, No 527, Berlin, 29 October 1885}

[Received 2 November. Recording telegram No 99]

Colonel Swaine suggests free passage for all German officers wanting to attend Indian army manoeuvres

I had the honour to forward to Your Lordship this day at in AM the following telegraphic dispatch Cypher: - $\mathrm{N}^{\mathrm{o}} 99$. 
Colonel Swaine hears he is to be sounded as to the extent to which hospitality will be offered to the Foreign Officers invited to the Indian Manœuvres. ${ }^{73} \mathrm{He}$ thinks that as English officers have for so many years enjoyed the hospitality of Foreign Governments at their autumn manœuvres we should do nothing that would risk a refusal of our invitation by any one county on the plea of expense.

He suggest that a passage free of all expense be given them in a troop-ship from Egypt to Bombay and back, and that while at Delhi they should be the guests of the Governor General. ${ }^{74}$ Colonel Swaine asks for an early reply.

\section{FO 64/1113: Edward Malet to Marquess of Salisbury, Very Confidential, No I7, Berlin, 9 January 1886}

[Received by [Messenger] Goodyear, undated. For: The Queen; Copy secret to: India Office / Teheran; Print (Asia)]

Discussion with Herbert von Bismarck about Baron Reuter's concession; Bismarck unwilling to commit to scheme of an international company for railway construction in Persia

With reference to Your Lordship's Despatches $\mathrm{N}^{\mathrm{O}} 37 \mathrm{I}$ of the $2^{\text {nd }}$ of September last and $\mathrm{N}^{\mathrm{o}} 55^{\circ}$ of the $22^{\text {nd }}$ ultimo, and to my Despatch $\mathrm{N}^{\mathrm{o}} 389$ of the $5^{\text {th }}$ of September, on the subject of Baron Reuter's concession, I have the honour to inform Your Lordship that I have recently pressed Count Bismarck to acquaint me with the views of the Chancellor ${ }^{75}$ on the project. $^{76}$

Count Bismarck now informs me that the Chancellor is unable to entertain the suggestion that Germany should join England and other Powers in starting the scheme as a "Compagnie Internationale des Chemins de Fer de Perse," under a guarantee. Such a step would require the consent of the Reichstag which it would not be possible to obtain, or advisable to ask.

On the other hand, if German Capitalists were to combine with English Capitalists and to start a Company on their own responsibility, Count Bismarck said that the Chancellor would not discourage

${ }^{73}$ Manoeuvres were scheduled for January I886.

${ }^{74}$ The Earl of Dufferin.

${ }^{75}$ Otto von Bismarck.

${ }^{76}$ On 5 September i885 Malet presented an unofficial memorandum to Herbert von Bismarck which outlined Reuter's proposal for a railway, stretching from Rasht to the Gulf, which was to be set up under the protection of 'certain powers'. He inquired whether the German government was disposed to join Britain in encouraging the scheme. The proposal went back to Reuter's concession of 1872 which was subsequently annulled by the shah as a result of domestic and Russian pressure. 
it or throw obstacles in its way. He should merely decline to give it official support.

Count Bismarck went on to give the reasons which led to this decision.

He reminded me of the general desire of the Chancellor to cooperate with Her Majesty's Government so long as such co-operation did not imperil his friendly relations with Russia, which, for motives, with which Your Lordship is cognizant, he is compelled to endeavour to maintain. To enter into the project submitted to him would be regarded as a direct combination against Russia; but apart from this he was of opinion that it would entail responsibilities which Germany would not be able to fulfil. The position of the State of Persia was, according to the accounts which he received from Tehran, already somewhat precarious and its danger could not but be enhanced by the prosecution of a scheme which contained so much that would provoke the fanatic feeling of the country. He finally returned to the cardinal objection that it would not be possible for him to obtain the consent of the Reichstag to a guarantee involving a new departure in general policy and future responsibilities.

Under all these circumstances The Chancellor was not disposed to join Her Majesty's Government in giving encouragement to Baron Reuter in the promotion of his present scheme, or to suggest to what extent or in what form assistance should be given to him.

\section{FO 64/i113: Charles S. Scott to Marquess of Salisbury, No 6o, Berlin, 3o January 1886}

[Received I February by Messenger Seymour. For: The Queen / Prince of Wales / Sir W. Harcourt / Vienna / Mr Childers; S[alisbury]]

Federal Council contests Prussian measures to expel Poles; debates in Prussian parliament; noteworthy speeches by Bismarck explaining reasons for policy

The Debates of the Second Chamber of the Prussian Parliament have this week acquired an unwonted interest from the remarkable speeches delivered by Prince Bismarck on Thursday and Friday night, for a fuller account of which I have the Honour to refer Your Lordship to the weekly summary of Parliamentary Proceedings by $\mathrm{M}^{\mathrm{r}}$ Corbett inclosed in my Dispatch $\mathrm{N}^{\mathrm{o}} 62$ of this day. 
As these speeches have caused no little sensation here, I venture to recall Your Lordship's attention to the circumstances which gave rise to them.

The Question on the orders of the day was the political necessity of recent measures taken by the Prussian Government for expelling a large number of non-Prussian Poles from the Provinces of Posen, Silesia and Prussia. ${ }^{77}$

From the weekly summaries of the Reichstag Debates transmitted by Sir E Malet, Your Lordship will have learnt that when these measures were first brought before the notice of the Reichstag, Prince Bismarck refused to allow an interpellation on the subject to be addressed to him in his character of Chancellor of the Empire, and cut short any attempt of this kind by leaving the House accompanied by the Representatives of all the Federal States in the Bundesrath. ${ }^{78}$

The Reichstag, ${ }^{79}$ however, in the exercise of what is considered its undoubted right, proceeded to discuss a form of petition on the same subject to the Bundesrath ${ }^{80}$ and this form was eventually voted by a majority of that Assembly, constituting, so to speak, a vote of Censure on the Policy represented by the Prince as Minister president of the Prussian Government. When this petition was brought up to the Bundesrath, that Body ${ }^{81}$ refused to entertain it, on the ground that the measures complained of were internal measures passed by a federal state in the exercise of its independent Sovereignty and, therefore, beyond the cognizance of the Federal Council.

In order to give Prince Bismarck the opportunity he desired to explain the policy of his Government in adopting measures which had given rise to such bitter attacks on the part of the National Representation of Germany, a motion was tabled in the Prussian Chamber $^{82}$ expressive of Confidence in Prince Bismarck, and thanking the Royal Government for their active defence of the Frontiers of the Kingdom and of the independence of its nationality.

Prince Bismarck ${ }^{83}$ has taken advantage of this opportunity to explain and defend his policy in one of the longest speeches on record in the Parliamentary annals of this Kingdom, and he has

\footnotetext{
${ }^{77}$ See n. 72 in this section.

${ }^{78}$ Sitting of I December I885; the interpellation, which was sustained by 155 deputies, was filed by the Polish faction on 26 November.

${ }^{79} \mathrm{On}$ I5 and i6 January i886.

${ }^{80}$ Federal Council.

${ }^{8 \mathrm{r}}$ On 23 January i886.

${ }^{82}$ On 23 January i886.

${ }^{83}$ On 28 January i886.
} 
done so with a frankness and disregard of popular criticisms which has taken the whole chamber by surprise.

While maintaining that the measures of expulsion hitherto adopted have simply been those which the Prussian State has, by ordinary law, a perfect right to enact, and have been applied solely to foreign Poles who had not acquired Prussian Citizenship, he does not hesitate to express his opinion that the open avowal by representative Poles of their aspiration for a separate Polish nationality, as distinct from that of their German fellow subjects, constitutes such a danger to the safety of the frontier of the Kingdom and Empire at large as would justify a Prussian Ministry in appealing to parliament for still larger powers.

He went on to say that he would regard such a Minister as an arrant coward were he to be deterred by any amount of resolutions in the Reichstag arrayed against him from adopting on his own responsibility any measures which he thought absolutely imperative for preserving the unity of the Kingdom and defending its frontiers from encroachment by a foreign nationality.

He indicated as measures of this kind which might become necessary - the voluntary or even compulsory appropriation by the State by the purchase at their full value of the properties of Polish Landowners in the German provinces, and their resettlement by a thoroughly loyal German population which should be restrained from intermarriage with Poles.

The Prince supported his arguments by reviewing at great length the whole history of the Polish Question, reading to the House a great deal of official correspondence on the subject which had not yet seen the light, to shew the impossibility of thoroughly amalgamating the Polish with the Prussian Element and maintaining that the incorporation of the Polish provinces with the Kingdom of Prussia was not based upon any compact between two contracting Powers, but on a proclamation of the recognized Sovereign, and that the promises made in that Declaration were not irrevocable, but liable to modification, if the results which it had desired to effect were not realized. ${ }^{84}$

The character of the encounter which followed this speech between Prince Bismarck and Herr Windthorst, the leader of the Centre ${ }^{85}$ who boldly supported the Poles on this occasion, may be judged from the summary of the two debates to which I have

\footnotetext{
${ }^{84}$ Bismarck was referring to the 'occupation manifesto' (Besitznahmepatent) of I5 May I8I5 and proclamation of the same date in which Friedrich Wilhelm III assured his 'new' subjects that they would not have to relinquish their nationality.

85 Zentrumspartei (Catholics).
} 
referred. I have referred to the Princes own speeches in a separate dispatch, as I cannot help thinking that the remarkable stress which he laid upon the danger of the situation in the Eastern provinces of the Empire may throw some light on the international policy of the Imperial Chancellor, and the considerations which have guided him in his relations with the Governments of neighbouring Empires.

\section{FO 64/iri6: Edward Malet to Earl of Rosebery, No 257, Berlin, I8 June 1886}

[Received 2I June by messenger. For: The Queen / Prince of Wales; R[osebery], 2I June i886]

\section{Unfounded rumours in press regarding Malet's removal as ambassador to Berlin}

In the course of an interview which I had on the $12^{\text {th }}$ instant, with Count Berchem, acting Secretary of State for Foreign Affairs, he remarked to me that the German newspapers had been busying themselves with me of late. I understood that he referred to an idle report which has gained currency, foreshadowing my transfer from Berlin to another post, not content with merely stating this, the "National Zeitung" had in a recent article $^{86}$ ascribed the course of my approaching removal, to the fact that my position as Ambassador has been shaken through the attitude which I assumed last year during the political differences between England and Germany.

Count Berchem went on to say that the Imperial Government has noticed these statements and intended to put a stop to them by a communication to the Cologne Gazette, the paper often used for inspired utterances.

An article in refutation of them has accordingly appeared and I have the honour to enclose copy and translation herewith. ${ }^{87}$

I am not able to throw any light on the concluding sentence of the paragraph which hints at the source of these rumours being known. I am inclined to regard them as mere journalistic elaborations of a rumour which appeared some time ago in the English Press.

\footnotetext{
${ }^{86}$ On 9 June I886.

${ }^{87}$ Enclosures: extract (untitled) from Kölnische Zeitung and translation, I5 June I886.
} 


\section{FO 64/ini6: Charles S. Scott to Earl of Rosebery, Confidential, No 29I, Berlin, I7 July I886}

[Received I9 July by messenger. For: The Queen / Gladstone / Paris for perusal, P.L. [printed letter], No 52I; R[osebery], 20 July; Copy to keep]

\section{No danger of war between France and Germany at present}

I read with much interest Sir E. Monson's despatch $N^{\circ} 70$ of the $9^{\text {th }}$ ultimo on the relations between France and Germany and the comments on its contents contained in Lord Lyons' Confidential despatch $\mathrm{N}^{\mathrm{O}} 337$ of the $25^{\text {th }}$ ultimo transmitted for my perusal in Your Lordship's Confidential despatch $\mathrm{N}^{\mathrm{O}} 347$ of the $\mathrm{I} 4^{\text {th }}$ instant.

Relying on the best information at the command of the Embassy I feel little difficulty in reechoing Colonel Villier's remarks that there is no more immediate or exceptional danger to be seen in the present state of relations between the two Governments than there has been any time in the last twelve or eighteen months: -

It is impossible to deny that relations between the two Governments are far less cordial than they were during the administration in France of Monsieur Ferry, ${ }^{88}$ and that Prince Bismarck has evidently finally abandoned many hopes which he had founded on the incipient good understanding effected at that time, but between this fact and actual danger there is a very great distance to be traversed.

No doubt the strict mot d'ordre to keep all irritating expressions and topics quiet has since been tacitly relaxed, and it may often serve the Chancellor's purpose when dealing with the question of Imperial Finances and the party of retrenchment, to keep the mind of the Parliamentary majority alive to the importance of not remitting any measures of defensive precaution, but it is impossible to conceive that Prince Bismarck, who keeps the foreign policy of the country firmly in his own hands, and has nothing more to gain for Germany or his own reputation by a successful, and everything to lose by an unsuccessful war, would allow the alarmist rumours, circulating chiefly in military circles in the provinces, to reach a point which would endanger a rupture between the two countries.

This, I feel confident, he would only do if absolutely convinced that the safety of the Empire was actually imperilled by any act of provocation on the part of France. If he really distrusts the Government at present in power in that country it is only because

\footnotetext{
${ }^{88}$ Jules Ferry's second term as prime minister was from February i883 to April I885.
} 
he distrusts its ability to keep popular clamour and agitation within the bounds of safe control.

\section{FO 64/ini7: Edward Malet to Earl of Iddesleigh, Confidential, No 332, Berlin, 21 August 1886}

[Received 23 August by messenger. For: The Queen / Lord Salisbury / Circulate / Embassies - confidential / East Department to see; F.B. [Francis Bertie]; I[ddesleigh]]

German government circles uneasy about Eastern events; desire for Britain to engage in bold policy to compensate for enfeebled three emperors' alliance

As long as Prince Bismarck is away from Berlin ${ }^{89}$ it is impossible to form any distinct notion of the views of the German Government upon passing events, but since my return ${ }^{9 \circ} \mathrm{I}$ have ascertained that there is a considerable feeling of uneasiness in Government circles regarding the future of events in the East. The sudden hostile effervescence of the Russian Press towards Germany has induced the presumption that the alliance of the three Emperors ${ }^{91}$ is weakened and this presumption is strengthened by the advances of France towards a better understanding with Russia being received in the Russian Press with favour..$^{92}$ The general situation has caused the keenest attention to be paid to the attitude which would be assumed by Her Majesty's Government and the announcement by Lord Salisbury ${ }^{93}$ that the traditional policy of the maintenance of the integrity of the Ottoman Empire will be followed has caused the liveliest satisfaction.

It is asserted that it is only necessary that this should be thoroughly understood at $\mathrm{S}^{\mathrm{t}}$ Petersburg for all danger to be allayed. Russia feels that England would have Austria[,] Germany and Italy as allies in a war to defend Turkey. On the other hand

${ }^{89}$ Bismarck left Berlin for Gastein on 31 July and returned on 28 August I886.

${ }^{90}$ Malet returned to Berlin from leave of absence on I4 August I886.

${ }^{91}$ The League of the Three Emperors, founded in 1873 but abandoned through the Dual Alliance of 1879 (see n. 489 in this section), was renewed in the Three Emperors' Treaty of I8 June I88I, albeit not as a formal alliance. In this, Austria, Germany and Russia agreed to maintain benevolent neutrality in the event of one signatory being at war with a fourth power, and to take into consideration their respective interests in the Balkans. Territorial changes in the European part of Turkey were subjected to prior agreement.

${ }^{92}$ The anti-German press reports were based upon the Bulgarian crisis, in particular the alleged German support of Alexander of Bulgaria, Russia's closure of the port of Batumi, which had been declared a free port by the Treaty of Berlin in I878, and, more generally, nationalist and economic issues with regard to Russia's role in the Balkans.

${ }^{93}$ On I9 August 1886, in the House of Lords. 
Germany will be unable to help Austria if England holds back because were she to do so, an active alliance would at once take place between France and Russia.

Austria therefore knowing that she cannot count on Germany if she engages war singlehanded with Russia will be compelled to look on quietly whatever Russia may do with regard to Bulgaria and Eastern Roumelia, consequently unless England's policy is unmistakable that of Austria will be weak and vacillating. ${ }^{94}$

There are many, who imagine that England is content because Egypt is in her group and that she will no longer hazard war to defend Constantinople, that at all events, she may consider that she may stand aloof at first and allow Austria to draw the chesnuts out of the fire or at least to bear the brunt of the first shock of war. Should this be the view held at $\mathrm{S}^{\mathrm{t}}$ Petersburg it is believed that war or, in any case events which would lead to war, were Austria not afraid to engage in it, would be near at hand.

England it is said need not enter into any alliance at present with Austria or Germany to avert the prospect, she has merely to show a bold front to let it be known that she will act in case of necessity and Russia will recognize that the present is not her opportunity.

\section{FO 64/in 8: Charles S. Scott to Earl of Iddesleigh, No $3^{82}$, Berlin, 18 September 1886}

[Received 20 September by messenger. For: The Queen / Lord Salisbury / Lord R. Churchill; I[ddesleigh]; S[alisbury]]

Social Democrats seek explanation of government policy regarding Bulgarian Question; political and public feeling over treatment of Prince Alexander in press; lack of sympathy for Bismarck's policy in the East

The National Zeitung, which is generally well-informed on such matters, states that the Socialist Party in the Reichstag held a meeting yesterday to discuss the possibility of forcing in the present extraordinary session an explanation from the Imperial Foreign Office of its action in the Bulgarian Question and a parliamentary discussion of its policy.95

To compel a reply from the Government the motion must have the support of at least thirty members, and when the explanation of

\footnotetext{
${ }^{94}$ For the unification of Bulgaria and the Ottoman province of Eastern Rumelia see n. I5 in Darmstadt section.

95 The Social Democratic faction intended to enquire whether Bismarck, in his consultations at Kissingen and Gastein that summer, had agreed to the deposition of Prince Alexander of Bulgaria and consented to the strengthening Russian influence in the Balkans. For the Bulgarian crisis see nn. I5, 25, and 27 in Darmstadt section.
} 
policy has been given it cannot be discussed unless a motion for leave to that effect is supported by fifty members of the House.

The Socialists in the House at present can only number twenty four votes and the National Zeitung doubt their being able to secure the necessary six votes from any other party. The same paper states that although the House will in all probability have no opportunity to hear or discuss publicly the foreign policy of the Chancellor, the reassembly of the Parliament $t^{96}$ has enabled the members of the legislature to discuss and exchange news privately, with the result that the confidence of the National Liberal Party in the wise guidance by Prince Bismarck of the foreign policy of the Emperor has been unanimously confirmed, that this feeling of confidence, however, does not exclude the existence of a very strong and general condemnation of the manner in which the semi-official press has dealt with Prince Alexander personally. The National Zeitung learns that the Liberalist and Free Conservative fractions on the contrary are far from unanimous in regard to their apprehension of Prince Bismarck's policy in the present crisis.

This description of the state of feeling of political parties corresponds with the general impression as to the public feeling of the country, and, although public opinion has not the same power to influence the foreign policy of the Empire as it has in other countries, it may be safely conjectured that Prince Bismarck is anxious not to provoke a parliamentary discussion of the Bulgarian question at the present moment. At no period in the history of the Empire has the feeling of the public and army been so much out of sympathy with the policy adopted by the Chancellor as in this question.

Conservative organs of the highest respectability and generally in touch with the Chancellor's political views have characterized the complacency with which the official and semi-official press viewed the treatment of a popular and heroic prince ${ }^{97}$ and compatriot as more than unfeeling, and have expressed their conviction that the reasons of state policy and the danger must have been extreme indeed to induce Prince Bismarck to do violence to feelings which, in his heart, he must personally share.

The apparent victory along the whole line of the Slav party which was but lately so rabid in its attacks on the German Chancellor and nation has been a bitter pill for the German public to swallow, and the high decoration conferred on Monsieur Katkow by the Emperor

\footnotetext{
${ }^{96}$ The Reichstag reconvened on I6 September I886.

${ }^{97}$ Alexander I of Bulgaria.
} 
of Russia for his service in educating the public opinion of his country has increased this bitterness..$^{98}$

With regard to this incident Count Bismarck ${ }^{99}$ admitted to me that it was rather a strange step to take at the present moment, but that it was probably only a "sop thrown to Cerberus"100 as it was quite possible that the Emperor Alexander privately did not view without apprehension the growing power of a party, some of whose proceedings were somewhat akin to those of the Nihilists.

\section{FO 64/i I 8: Edward Malet to Earl of Iddesleigh, No 416, Berlin, 9 October I 886}

[Received II October by messenger. For: The Queen / Prince of Wales / Lord Salisbury; I[ddesleigh]]

German press desirous of knowing whether there is a political objective in Randolph Churchill's private visit to Germany

Much comment has been made in the newspapers this week on the visit to Berlin of Lord Randolph Churchill travelling as $\mathrm{M}^{\mathrm{r}}$ Spencer and the inquiries of newspaper correspondents at the Embassy have been unceasing during the last three days. ${ }^{\text {Ior }}$ To these applicants it was easy enough to state that nothing was known here regarding it, but to others I have been obliged to be a little more explanatory, especially to Count Bismarck, ${ }^{\text {102 }}$ who was good enough to say, on reading in the English newspapers of the intended visit, that he should see Lord Randolph with much pleasure.

I have explained that His Lordship merely came abroad for the sake of relaxation from his arduous duties and that he was particularly anxious that no political significance should be attached to his journey. Had he come to see me during his stay here, it would have involved his either making other visits or refusing to make them, both of which courses would have been open to misinterpretation by newspaper correspondents who watched all his movements. It therefore appeared to me that he exercised a sound discretion in

\footnotetext{
${ }^{9}$ Katkov, editor of the Moskouskiye Vedomosti, was awarded the Order of Saint Vladimir, $2^{\text {nd }}$ class, on io September I886.

${ }^{99}$ Herbert von Bismarck.

${ }^{100}$ Cerberus was the three-headed watchdog who guarded the gates of the underworld. Virgil's Aeneid relates how he was distracted by a sop, or drugged cake, that was given to him in order to let Aeneas slip safely past on his journey to visit his father's spirit.

${ }^{\text {Ior }}$ On his way to Vienna via Dresden and Prague, Randolph Churchill also visited Berlin on 6 and 7 October I886. He returned to London via Paris on 2I October.

${ }^{102}$ Herbert von Bismarck.
} 
remaining completely aloof, and that his doing so was the only sure means of securing the rest which he desired and of avoiding the supposition that his journey had a political object.

I may add that I abstained on the above grounds from intruding on Lord Randolph's privacy during his stay here. Under other circumstances it would have given me great satisfaction if I could have contributed in any way to promoting the comfort or interest of his visit.

\section{FO 64/III 8: Edward Malet to Earl of Iddesleigh, Confidential, No 419, Berlin, 14 October 1886}

[Received I8 October by [Messenger] Woodford. For: The Queen / Prince of Wales / Lord Salisbury / Constantinople / Intelligence Department; H.B. [Henry Brackenbury]; S[alisbury]; I[ddesleigh]]

German foreign office has adopted Daily Telegraph's correspondent to Berlin as its mouthpiece

It may be useful for Your Lordship to know that the German Foreign Office, which is usually not only reticent but dumb towards foreign newspapers correspondents, has recently taken under its wing $\mathbf{M}^{\mathrm{r}}$ Bashford, correspondent of the Daily Telegraph at Berlin, and supplies him with news which it wishes to circulate. A curious instance of this was related to me yesterday by this gentleman. He has been placed in communication for the purpose of obtaining information, with Herr Tchiersky ${ }^{103}$ of the Foreign Office, who acts in some respects as Private Secretary to Count Bismarck. ${ }^{104}$ Two days ago he asked Herr Tchiersky whether there was any truth in a rumour that the Russian Government were endeavouring to obtain from the Sultan $^{\text {105 }}$ an island in the sea of Marmora. Herr Tchiersky replied in the negative, but in the evening $\mathrm{M}^{\mathrm{r}}$ Bashford received a message asking him to call again in the morning. At the interview which took place in consequence, Herr Tchiersky told $\mathrm{M}^{\mathrm{r}}$ Bashford that he knew nothing about the rumour concerning the island, but that it was certainly the case that the Russian Government was using its utmost endeavours to bring the Sultan under Russian influence, and would probably make considerable promises to gain their end; that what the Russians desired was to induce the Sultan to permit the fortification of the Dardanelles under their supervision. He told $\mathrm{M}^{\mathrm{r}}$ Bashford that he might make any use he liked of this information provided he did not divulge its source.

\footnotetext{
${ }^{103}$ Heinrich von Tschirschky und Bögendorff.

${ }^{104}$ Herbert von Bismarck.

${ }^{105}$ Abdul Hamid II.
} 
He appears generally to communicate very freely on all subjects with $\mathrm{M}^{\mathrm{r}}$ Bashford so that if Your Lordship should desire to learn what news the German Government wishes the English newspapers to give, it can be found in the letters in the Daily Telegraph from its correspondent at Berlin.

\section{FO 64/irig: Edward Malet to Earl of Iddesleigh, Most Confidential, No 455, Berlin, 12 November 1886}

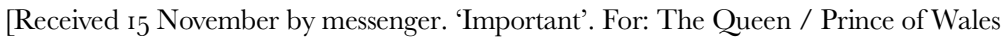
/ Lord Salisbury / Lord R. Churchill / Circulate to Cabinet in M.S. / Copy for Print (South East Europe) / Secret to: Embassies / Sofia; S[alisbury]; I[ddesleigh]]

Bismarck's views on Bulgarian Question; his belief that Austria should not go to war with Russia; Germany to attack France if French invade England

Prince Bismarck, who returned the day before yesterday to Berlin, requested me to come to see him this afternoon, and, at the interview which resulted, he spoke to me at length upon the situation in Bulgaria.

He said that the conduct of General Kaulbars ${ }^{106}$ was not to be attributed to his personal character, that he was quiet and gentlemanlike in his intercourse with all except the Regents, the members of the Government and their adherents, to whom he had behaved like a ruffian, that this bearing was the result of direct instructions from the Emperor, who regarded the Regency ${ }^{107}$ as the legacy of the Prince of Bulgaria to whom His Majesty was still implacably indisposed. General Kaulbars, however, must bear his share of responsibility, for he had made false reports to The Emperor and had misled him. Prince Bismarck said that he had proof of this in an incident with which he had had to deal. General Kaulbars had informed the Emperor that Mr. Thielmann, the German Agent at Sophia, had written to him an insulting letter regarding the firing in the direction of the German agency on the occasion of the elections, ${ }^{108} \mathrm{Mr}$. Thielmann was consequently instructed to send a copy of the letter which he had written, and it proved to be one such as

\footnotetext{
${ }^{106}$ Kaulbars was sent as special commissioner to advise the Bulgarian government and represent Russian interests. He arrived at Sofia on 25 September 1886 and was withdrawn alongside all Russian consular officers in Bulgaria and Eastern Rumelia - on I7 November.

${ }^{107} \mathrm{On} 7$ September I886, the day that Alexander abdicated as prince (knyaz) of Bulgaria, he appointed a regency comprised of three members.

${ }^{108}$ On II October, the second day of the elections to the national assembly, peasants from the neighbourhoods of Sofia, incited by the speech of a Russian representative, attempted to obstruct proceedings. Shots were apparently fired from the Russian consulate
} 
one gentleman would write to another, and contained nothing which could give the slightest grounds for the accusation of insolence. Prince Bismarck had therefore instructed the German Ambassador at $\mathrm{S}^{\mathrm{t}}$ Petersburgh $^{\text {rog }}$ to inform M. de Giers that the Russian Agent was a liar. M. de Giers had not dared to communicate this to The Emperor, and the Prince had therefore taken an opportunity to inform the Grand Duke Vladimir, who has recently been here, of the incident, and had begged him to relate it accurately to The Emperor on his return to $\mathrm{S}^{\mathrm{t}}$ Petersburgh. ${ }^{\text {1о }}$

Prince Bismarck then spoke of the candidature of the Prince of Mingrelia and I said that I was permitted to inform him confidentially and unofficially that Her Majesty's Government were of opinion that it was contrary to the plain intention of the Treaty of Berlin, which excluded members of the Dynasties of the Great Powers of Europe, and that a Prince, who was a vassal of one of them, seemed to be equally objectionable. ${ }^{\text {In }}$

Prince Bismarck replied that this objection was too sweeping, that all candidates were either vassals or subjects of one or other of the Great Powers, but, waiving the argument, he reverted to the candidature of the Prince of Mingrelia, ${ }^{112}$ and observed that he thought that Russia would be no better off if that Prince were in Bulgaria than she was when Prince Alexander was there, that the Prince of Mingrelia was not a Russian, that he was not likely to entertain strong feelings of gratitude towards the Power which had deprived him of his inheritance, and that his marriage with the elderly daughter of Count Adlerberg ${ }^{113}$ showed that his ideas of honour were not highstrung. He would probably begin as Prince Alexander had begun, and, eventually be swayed by the Bulgarian popular current.

Prince Bismarck proceeded to speak about Austria. He said that, as far as he could judge at present, the Emperor of Russia did not intend to occupy Bulgaria, but that, should he change his mind,

after they sought refuge there, which hit the walls of the British and German consular agencies.

${ }^{\text {109 }}$ Hans Lothar von Schweinitz.

${ }^{110}$ The Grand Duke Vladimir visited Berlin on 30 November 1886 on his way to Weimar.

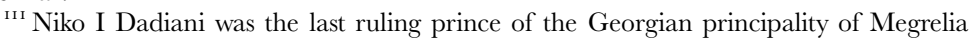
which was abolished by Russia and annexed to the latter in 1866. He remained close to the Russian court and in early November i886 Russia suggested that he be nominated for the election of Prince of Bulgaria. Article 3 of the Treaty of Berlin of I878, which established Bulgaria as an autonomous principality of the Ottoman Empire, stipulated that no member of the reigning houses of the great European powers should be elected Prince of Bulgaria.

${ }^{{ }^{112}}$ Niko Dadiani. 
and were an occupation to take place, Austria would in the Prince's opinion be wrong to oppose it. "At all events", he said, "we should not assist her were she to do so: our relations with Austria do not bind us to that - we wish that she should maintain herself as she is. Her existence is necessary to us for the European Equilibrium. We cannot allow her to disappear or to be essentially weakened. This was my view in $1866,{ }^{114}$ and I carried it against my King, who was of the contrary opinion. But, in the present situation, Austria has placed herself on a new platform. She seems to consider that she must contend against Russia regaining the influence in Bulgaria, contemplated by the Treaty of Berlin. There we cannot follow her. Besides she would be ill-advised in her own interest to do so. She will be much more powerful as an adversary of Russia the day that the occupation takes place. At present Russia can attack her on the coterminous frontier and wars go rapidly. There is now-a-days no question of winter quarters. A fortnights campaign decides the fate of an empire, and Austria is not prepared. We have bad accounts of her organisation, of her cavalry and of her artillery. In these matters she has been the victim of Parliamentary exigencies, seeking retrenchment where expenditure is the patriotic policy. In this respect she resembles England. We do not want her to go to war, because we should be obliged to interfere to prevent her from being essentially weakened. We cannot permit the vacuum in Europe which such an event would create. But the Emperor and I are old and we wish that peace should continue until we go."

My policy with regard to England is the same as it is with regard to Austria. In the case of a war between England and France, if the English Fleet were to be destroyed, and a French invasion of England became imminent, we should at once make war on France, because we could not permit the power of England to be destroyed."

I asked the Prince whether he considered that the reasons which reder [Note in margin: '? render'] it unadvisable for Austria to oppose the occupation of Bulgaria by arms applied equally to England, whether such an event would not open the door for Russia to Constantinople, whenever she chose to take advantage of it? The Prince somewhat evaded the question. He said that he considered it to be of extreme importance to England to gain the confidence of the Sultan ${ }^{\mathrm{n} 5}$ and that, by alienating that confidence, $\mathrm{Mr}$ Gladstone had done incalculable, perhaps irreparable, harm to his

\footnotetext{
${ }^{114}$ During the course of and after the Austro-Prussian war.

${ }^{115}$ Abdul Hamid II.
} 
country. ${ }^{116}$ He said that he was extremely glad that Sir William White was at Constantinople, because he was a clever man and would do what lay within the means of an Ambassador to bring the Sultan round. I spoke of a Russianised Sultan being a great danger to England. The Prince was of opinion that the Sultan could not go far in this direction. His obsequiousness to Russia even now caused him to be in danger. The native Mussulman feeling was strongly opposed to it, and were he to pursue the policy to extremes he would disappear like Sultan Abdul Aziz. ${ }^{\text {I17 }}$

I should add that when speaking previously of a possible Russian occupation of Bulgaria, Prince Bismarck had said that Austria ought not to interfere, even if Russia went to Constantinople; for that the day Russia effected this, she would be so weakened that Austria would become comparatively powerful.

At the conclusion of the interview, I thanked Prince Bismarck for informing me of his views. He replied, "I have spoken to you frankly, but you must regard what I have said as quite confidential."

\section{FO 64/1155: Edward B. Malet to Her Majesty's Principal Secretary of State for Foreign Affairs, ${ }^{118}$ No 13 , Berlin, 15 January 1887}

[Received I7 January by messenger. For: The Queen / Prince of Wales / Circulate / Eastern Department; S[alisbury]]

Vote on the army bill in the Reichstag; speeches by Bismarck on his policy with regard to other European Powers

The Vote on the Army Bill was taken yesterday in the Reichstag, and resulted in the adoption of Freiherr von Stauffenberg's amendment, limiting the duration of the grant to three years instead of seven, as demanded by the Government, by I86 Votes against I54. There were 28 abstentions, the number of deputies present $368 .{ }^{\text {II9 }}$

\footnotetext{
${ }^{116}$ Bismarck was generally referring to Gladstone's engagement with the 'Eastern Question' before and during his second premiership (I880-I885), and especially with regard to the question of the Ottoman Empire's territorial integrity.

${ }^{117}$ Abdülaziz was deposed by his ministers in May 1876 .

${ }^{118}$ The Earl of Iddesleigh died on I2 January 1887; he was succeeded by Lord Salisbury on I4 January, who as well as being foreign secretary also held office as prime minster.

${ }^{119}$ Stauffenberg proposed the amendment to the bill (introduced on 25 November I886) on II January 1887. The original bill was reintroduced after the convocation of the newly elected Reichstag, it was passed on II March 1887 and enacted in the Imperial Military Law of II March i887. It allocated supplies for a peacetime army of 468,406 men until $3^{\mathrm{I}}$ March i894.
} 
The speeches made by Prince Bismarck in the course of the debate ${ }^{120}$ have reviewed the political situation of Germany with regard to other Powers, but what he has said has thrown no new light upon it, and has had no surprises to those who have lived in the atmosphere of his political views and conversations.

The aim of his policy is peace, in order that there may be time for the complete consolidation of the German Empire. This consolidation is the one object which he has in view, and he considers peace to be the primary condition of its attainment.

He believes, however, that the best way to preserve peace is to be strong enough to inspire other Powers with the conviction that Germany is able not only to hold its own, but to inflict chastisement on any Power that attacks it. He will not be turned aside from maintaining the most friendly relations with Russia, but he has taken the opportunity to deny that there is any truth in recent rumours to the effect that there is a special alliance between the two countries. "I do not know" he said "how Herr Windhorst [ sic $]^{121}$ comes to know that Russia is our ally. If he has secret intelligence that Russia wishes to conclude an alliance with us against France, I shall be thankful to him to communicate it to me ..."

I have stated my conviction that Russia will not attack us, will not conspire with other Powers, and seeks no alliance against us. But we can reckon on no alliance with her if we should be at war with France. The report is, therefore, erroneous and I am constrained to give it a timely contradiction"[.]

With reference to Austria he dwelt upon the success of his efforts to be on the most friendly terms with her. "In regard to Austria our relations are firmer and more intimate than they ever were, either at the time of the Confederation or in the days of the holy Roman Empire, as all the questions which were the cause of strife for centuries between us have been settled through mutual confidence and good will'"[.]

Prince Bismarck's distrust of France is too well known for his statements in support of it to have caused any surprise, and the effect of the vigour of his language in describing his apprehensions seems to have been discounted beforehand, and to have given rise to no feeling of resentment or surprise.

On the whole, the general effect of his speeches has been to tranquillize the public mind with regard to the danger of war.

\footnotetext{
${ }^{120}$ On II, I2, and I3 January 1887.

${ }^{121}$ Bismarck made this speech on II January and was referring to Windthorst's Reichstag speech of the same day.
} 
After the vote was announced, Prince Bismarck read an Imperial message, dissolving the Reichstag, and so ended the beginning of a Parliamentary struggle of which the result cannot at present be foreseen.

\section{FO 64/1155: Edward B. Malet to Marquess of Salisbury, Confidential, No 25, Berlin, 29 January 1887}

[Received 3I January by messenger. For: Eastern Department / The Queen / Prince of Wales / Print (S.E. Europe) / Embassies; Qy: War Office / Intelligence Department; S[alisbury]]

Reflections on Bulgarian crisis; Bismarck's viewes and his policy on this matter; Bismarck's insistence on Septennate for army bill

The sensational reports which have appeared from some time past in the papers, coupled with the taking of measures indicative of insecurity, such as the prohibition ${ }^{122}$ to export horses from Germany, have produced a state of apprehension in the public mind which lead me to submit some remarks upon the situation.

For more than a year Europe has been kept in agitation by the Bulgarian Crisis. ${ }^{123}$ When it began, Prince Bismarck, though he would not overtly aid the aspirations of the two Bulgarias, was not sorry to see them united. He could watch this union with complacency because it formed part of the Russian programme, and with satisfaction, because he knew that it would be a barrier to Russian aggrandisement. The downfall of Prince Alexander was a blow to his policy, because it forced him in a moment to decide whether he would support Russia or England. Austria did not count. For the sake of German interests Prince Bismarck would have been compelled at any hazards to restrain her, if Great Britain was not prepared to send her fleet into the Black Sea, that is to declare war on Russia. Whether we would do so or not was doubtful. The consequences of our not doing so would have been the defeat of the Austrian forces and a war forced upon Germany, at a tremendous disadvantage, to retrieve the disaster. That, at least, was the view taken here by the authorities acquainted with the military resources of Austria.

\footnotetext{
${ }^{122}$ Imperial decree of 25 January 1887. The reports in question which, in part, were stirred up by Bismarck's Reichstag speech of II January (see preceding dispatch), referred to the French threat to peace, and in particular to the French war minister's (Georges Boulanger) anti-German policy.

${ }^{123}$ For the Bulgarian crisis see pp. $7 \mathrm{O}^{-} 73$ and nn. ${ }^{15}$ and 25 in Darmstadt section.
} 
Prince Bismarck embraced certainty, and supported, Russia, but his bitterest regret was that Prince Alexander did not defy Russia and say, "J'y suis, j'y reste." ${ }^{124}$ [Note in margin (Thomas Sanderson): 'Prince B. showed no signs of wishing or encouraging such a decision']

What was the situation at the moment that the Prince abdicated? The Emperor of Russia had said, "as long as you remain, there can be no issue to the question between Russia and Bulgaria." But it is known that the military Authorities of Russia were against occupation and that the pacific tendencies of the Emperor are extreme. He would have sulked, and the consolidation of the Bulgarias under the Prince would have become an accomplished fact.

Prince Bismarck said to me in the course of a conversation in which he declared that he could not understand why the Prince had abdicated; "it was the moment for a great man."

Meanwhile Prince Bismarck had decided on his own policy. Bulgaria was nothing to Germany. Russia might do with it as she chose. It quickly appeared, however, that the voice of Prince Bismarck was no longer all powerful. Public opinion in Germany blamed him. Notwithstanding his advice to the contrary, Count Kalnoky found that he was compelled to use vigorous language to the Delegations, and the tension which from that moment sprang up between Austria and Russia fortified by Your Lordship's speech at the Mansion House, because it was supposed to be prompted by an understanding between the Austrian and the British Governments, has never been allayed. ${ }^{125}$

Prince Bismarck knows that the real danger of war lies in the East. $\mathrm{He}$ is therefore endeavouring to divert the attention of the whole of Europe to the fear of a war between Germany and France. By this means he believes that the Bulgarian question may drop into insignificance. Before the tremendous results which may spring from a war between France and Germany and the efforts which would be made to prevent it, the fate of Bulgaria would pale and no longer trouble the peace of Europe.

$\mathrm{He}$ is assured that France will not make war, [Note in margin: 'Mr Waddington's language is to the same effect.' T.H.S. [Thomas Henry Sanderson]] however provocative may be his attitude. He counts upon the alarm and agitation which he intends to excite to

\footnotetext{
${ }^{124}$ French: 'Here I am, here I remain.'

${ }^{\text {I25 }}$ Malet is referring to a speech that Count Kálnoky, the Austro-Hungarian minister for foreign affairs, made to the Hungarian Delegations at Budapest on I3 November I886 in which he stated Austria-Hungary's readiness to act in the event of a Russian military occupation of Bulgaria. In his speech at the Lord Mayor's Banquet on 9 November I886, Salisbury stressed the importance of the Berlin Treaty for Bulgaria's independence and stated that 'Austria's policy will to a great extent govern that of England'.
} 
procure the passing of the Army Bill, and his extraordinary tenacity in insisting on the Septennate is to be ascribed to the one dominant aim of his life, which is to leave the Empire which he has created, safe from all attack and so to ensure to it time, as far as human foresight can, for self-consolidation. ${ }^{126}$

It has been considered that his insistence on the Septennate when the Reichstag was willing to vote the Bill for three years, was a sign of obstinacy arising from the plenitude of success in the course of his great career. This is not so; he knows that with the life of the Emperor the actual order of the state politic in Germany, as it exists at present, closes, and that a new order of things will arise in which the Imperial Government will have the most serious Parliamentary difficulties to face. He regards the efficiency of the Army as indispensable to the safety of the country and he desires to render its dependence on the Parliamentary troubles, which are certain to ensue upon a change of Sovereign, as remote as possible.

The tone of German Officers is, for the moment, exceedingly warlike, but that need give no apprehension. In assuming such a tone they are probably obeying a hint, and the Army is under perfect control; the danger, if there is one, comes from France, but I presume that the reports which Prince Bismarck receives convince him that that Power will not be moved to action by defensive precautions on the part of Germany.

\section{FO 64/1156: Edward B. Malet to Marquess of Salisbury, Confidential, No 9o, Berlin, 12 March 1887}

[Received I4 March by messenger. For: The Queen / Prince of Wales / Paris; S[alisbury]

Bismarck's ways and means of manufacturing and moulding public opinion

In my Despatch No 33, Secret of the $\mathrm{I}^{\text {st }}$ of February I mentioned what Prince Bismarck said to me with regard to the duty of a statesman to endeavour to create public opinion. The remarks did not seem to me at the time to be particularly apposite to the point he was endeavouring to urge which was the advantage of an alliance between England and Italy, ${ }^{127}$ but he laid so much stress upon them that I could not but insert them in their place in recounting the Conversation.

\footnotetext{
${ }^{126}$ For the army bill (Imperial Military Law) see preceding dispatch and n. II9 in this section.

${ }^{127}$ An agreement to maintain the status quo in the Mediterranean was concluded between Britain and Italy - through German mediation - on I2 February 1887.
} 
Looking back at the events of the last few weeks inclines me to think that he was, at that time, engaged, to the fullest extent, in putting in practice what he was inculcating as the duty of the head of a Government. He was in fact leaving no stone unturned in inducing the public to believe that war was imminent, and that the only means to stave it off was to return a majority to the Reichstag in favour of the Septennate. ${ }^{128}$ I do not say that this was not his own honest opinion. I would merely call attention to the variety of levers which he used to bring the people of Germany to share his own view and to the marvellous success with which he himself practised the lesson which he preached.

During what may be called his campaign on public opinion, hardly a day passed without some fresh incident occurring to pile up the agony of apprehension, most of them indeed were molehills, but so successfully manipulated as to appear like mountains to the anxious Electors. He said to me that it was the duty of a Minister to colour the Government stream. He was certainly dyeing it with the deepest hues. Nothing was met in Government circles with a sterner rebuke than an insinuation that the war scare was being raised for electioneering purposes, but the calm which has succeeded the elections goes a long way to confirm the faintly uttered suspicion. ${ }^{129}$

Were Prince Bismarck to speak to me again on the subject, he could point triumphantly to what has occurred in this instance as illustrating the possibility and utility for Government purposes of creating public opinion.

\section{FO 64/1156: Edward B. Malet to Marquess of Salisbury, No I 8, Berlin, 29 March 1887}

[Received 4 April by messenger. For: The Queen (returned from Aix unmarked) ${ }^{130} /$ Circulate / Copy to: Rome/ Paris, P.L. [printed letter], 6 April; S[alisbury]]

New Prussian church bill to cease state conflict with Catholic Church; Bismarck's remarks on nature of past conflict and present circumstances as being favourable for peace

In my Despatch $\mathrm{N}^{\mathrm{O}}$ II 7 of the $28^{\text {th }}$ instant I had the honour to submit to Your Lordship a report of the discussions in the Prussian Parliament on the ${ }^{\text {st }}$ reading of the New Church Bill, the object of which is to terminate the long contest between the Prussian

\footnotetext{
${ }^{128}$ For the army bill (Imperial Military Law) see n. II9 in this section.

${ }^{129}$ Elections to the Reichstag were held on 2I February 1887.

${ }^{130}$ Victoria stayed in Aix-les-Bains from 6 to 28 April 1887.
} 
State and the Roman Catholic Hierarchy, and to consolidate peaceful relations between the Governments of Berlin and the Vatican. ${ }^{131}$

This Bill has in some quarters been characterized as an inglorious Surrender by Prince Bismarck of principles which he formerly held to be essential, and he is accused of having at last done penance at Canossa $^{132}$ in order to secure the assistance of the Vatican in questions of purely internal German Policy.

Prince Bismarck has boldly refuted this charge in the able speech summarized in the report of Parliamentary Proceedings above referred to, and in an article of evidently official inspiration in yesterdays Norddeutsche Allgemeine Zeitung ${ }^{133}$ to which are appended extracts from the official correspondence which took place between Berlin and the Vatican in i87i previous to the commencement of the War waged with the Roman Catholic Hierarchy.

Prince Bismarck's speech and the correspondence quoted, clearly explain the nature and object of that War and of the May laws.

The "Centre", ${ }^{134}$ most of whose members owed their election to Clerical influence, had, from the very commencement of the work of consolidating the German Empire, assumed a policy of Obstruction; - as the Chancellor maintains, - with the object of compelling the Imperial Government to interfere actively in defence of the Pope's territorial position at Rome. ${ }^{135}$ This obstruction was offered on questions of a purely political interest without reference to Church matters, e.g. the framing of the Imperial Constitution, the Incorporation of Alsace Lorraine, the Polish and Guelph Questions: the Catholic members of the "Centre" on each of these questions taking the side of the anti-national and anti-unionist Malcontents.

Prince Bismarck ${ }^{136}$ urged the Vatican to express openly its disapproval of this line of action or, at any rate, to prove that it discountenanced it. Cardinal Antonelli was favorably disposed to listen

\footnotetext{
${ }^{13^{1}}$ The bill which amended the anti-Catholic legislation (May Laws; see n. I7 in Munich section) of I873, I874, and I875, as well as the Third Mitigation Law of I I July I883 and the First Peace Law of 24 May 1886, was debated and passed in the Prussian upper house on 23 and 24 March I887; the chamber of deputies followed suit on 27 April. The Second Peace Law came into effect on 29 April i887.

${ }^{132}$ Bismarck's speech of 1872 , in which he refused to submit to Catholic influence in German affairs and used a reference to Heinrich IV's submission to the pope at Canossa in 1077 as an illustration of secular powers deferring to the Catholic Church, became renowned as the 'we will not go to Canossa' speech.

${ }^{133}$ Norddeutsche Allgemeine Zeitung, 27 March 1887.

${ }^{134}$ Zentrumspartei.

${ }^{135}$ Malet is referring to the demands for the reestablishment of temporal papal sovereignty following the takeover of the Papal States by the Italian kingdom in I870.

${ }^{136}$ Bismarck to Tauffkirchen, I7 April I87I.
} 
to this request, but the Catholic Party in Germany eventually prevailed over his influence, sent a Deputation to the Pope, headed by Prince Löwenstein, ${ }^{137}$ who finally induced Pope Pius IX to bluntly refuse to interfere in any way with the action of the German Catholics in Parliament. ${ }^{138}$

Hereupon Prince Bismarck instructed the Prussian Chargé d'affaires ${ }^{139}$ to warn the Vatican that it must accept the consequences of any severe measures which the Prussian Government might be obliged to take in self protection.

The May Laws, as Prince Bismarck reminds the Parliament and public, were especially described by him at the time as a warlike weapon to be used to obtain an object; and were not a permanent institution fitted for a time of peace.

Pope Pius IX persisted in his hostile attitude, but in 1878 his Successor Pope Leo evinced a more conciliatory disposition, and from that time it had been the Chancellor's desire to facilitate a reestablishment of peaceful relations.

He hoped that peace had now been firmly established. Pope Leo had consented to do what Pope Pius refused, and discountenanced the Anti-national political Agitations of the German Catholics, and the Prussian Government could therefore safely lay aside the weapons which they had used in the war. The Prussian Government had always been desirous of securing to the Roman Catholic Church in Prussia all the rights and privileges to which it attached value, and which were not incompatible with the preservation of any of the essential Sovereign rights of the Prussian Crown.

The present Bill secured all this.

He would hesitate to assert of any peace that it was a permanent one, but he had perfect confidence in the wise and peaceful disposition of the present Pope, and if the peace was at any time broken, they could always take the weapon out of the armoury again.

I have been induced thus shortly to summarize the pith of the Chancellor's explanations, as it seems to me singularly characteristic of the mode in which Prince Bismarck treats political difficulties, and because the effects of the policy he has adopted ?/is [sic] likely to exert an influence beyond the question it has been applied.

\footnotetext{
${ }^{137}$ In June I871, on the occasion of Pius IX's $25^{\text {th }}$ anniversary as pope (I6 June).

${ }^{13}{ }^{8}$ Malet is referring to Antonelli's conversation with Tauffkirchen on 23 June I87I.

${ }^{139}$ Bismarck to Tauffkirchen, 22 (telegram) and 30 June I87I.
} 


\section{FO 64/1156: Gharles S. Scott to Marquess of Salisbury, Confidential, No 146, Berlin, 20 April 1887}

[Received 20 (25) April by messenger. Extends telegram No 22. Print (Western Europe); S[alisbury]]

Various opinions with regard to the impact of German military preparations on relations between France and Germany

In reply to Your Lordships telegram $\mathrm{N}^{\circ} 68$ of this days date inquiring whether I considered that there was any imminent danger of a rupture between Germany and France, I have the honour to report that in the course of a conversation which I had with Count Bismarck ${ }^{140}$ today I mentioned to His Excellency that I had heard that a good deal of uneasiness existed at present at Paris on account of the continued military preparations in Germany. He replied that the uneasiness manifested by the French Government was all fictitious and that their object was to maintain the apprehensions of the people in order to have pretext for their own Armaments. Count Bismarck added that there was not the remotest intention on the part of Germany of attacking France.

In Colonel Swaine's opinion the military preparations that are being made in Germany are of such a nature as to lead to the supposition that a war with Russia is deemed more likely than one with France. The nature of the transport which is being prepared points to its use in Russia rather than in France.

Monsieur Herbette, the French Ambassador, told me today that he had just returned from a visit to Stettin, and that there, war between Germany and Russia was talked of as imminent. He seemed however to have no apprehension of a rupture between Germany and France at present.

\section{FO 64/1156: Gharles S. Scott to Marquess of Salisbury, Very Confidential, No r5o, Berlin, 23 April 1887}

[Received 25 April by messenger. For: The Queen / Prince of Wales / Print (Western Europe) / Embassies / Intelligence Department; $2^{\text {nd }}$ : Confidential to War Office; S[alisbury]]

Franco-German tension; report by Colonel Swaine; supplementary war budget

I have the Honour to enclose, herewith, a confidential report ${ }^{141}$ which Colonel Swaine [Note in margin: 'Col. Swaine No. 34 of 20 April

\footnotetext{
${ }^{140}$ Herbert von Bismarck.

${ }^{14 \mathrm{I}}$ Enclosure: confidential report No 34 by Colonel Swaine, Berlin, 20 April I887.
} 
I887'] has made for Her Majesty's Ambassador ${ }^{142}$ of a conversation which he recently had with a high Military Authority here.

In view of the renewal of uneasiness which Lord Lyons reports as existing at Paris in regard to the intentions of Germany, I venture to invite Your Lordship's special attention to the information which Colonel Swaine has elicited from an exceptionally well-informed source.

This information confirms the impression which I have derived from other sources, that Germany has neither the desire nor intention to provoke hostilities in any quarter, but that the uncertainty of the political situation at $S^{t}$ Petersburgh, and the effect of this uncertainty on certain political parties at Paris, ${ }^{143}$ renders it imperative on the German Government to be prepared for all contingencies, to strengthen good relations with other Powers, and at the same time to show the world that she is in a position to repel attack or resist pressure on her Eastern as well as Western frontier.

It is with this object that her military preparations are being hurried on, - the Supplementary War Budget necessitated by the New Military Septennate has just been published, the amount required, one hundred and seventy two millions of marks, [Note in margin: $172,000,000]$ which will have to be raised by a further loan, - is larger than the public had expected, and I have little doubt that in order to secure its passing the Reichstag, the dangers of the political situation will be somewhat accentuated in the official and semi-official utterances of the next few weeks, but it would, I think, be a mistake to infer from this that the situation has, at present, become more menacing in any quarter than it was a month ago. ${ }^{14}$

\footnotetext{
${ }^{142}$ Edward Malet.

${ }^{143} \mathrm{Scott}$ is referring to the struggle between the Russian foreign minister, Nikolai de Giers, and the conservative publicist Mikhail Katkov for primacy in Russian foreign policy. Katkov's anti-German agitation was paralleled in France by the minister of war, General Boulanger.

${ }^{144}$ The bill was introduced on 22 April and passed by the Reichstag on 20 May 1887. For the underlying Imperial Military Act of II March I887 see n. IIg in this section.
} 


\section{FO 64/1156: Gharles S. Scott to Marquess of Salisbury, No 157, Berlin, 28 April 1887}

[Received 2 May by messenger. Print (Western Europe) / Embassies; S[alisbury]]

Schnabelé incident politically contained; summary of events and suppositions

The general impression in all well-informed circles here, is that the Schnaebele incident ${ }^{145}$ will not be allowed to assume a dangerous Character, but that a settlement satisfactory to the 'amour propre" of both countries will soon be arrived at between the two Governments. Monsieur Herbette has had several interviews on the subject with Count Bismarck, ${ }^{147}$ and has furnished His Excellency with all the documents in support of the French side of the case, which reached him by special Messenger from Paris on Sunday night.

Count Bismarck was good enough to show me yesterday two of these documents - photographic facsimiles of two letters ${ }^{148}$ addressed by the German Police Officer, Herr Gautsch to his "Cher Collègue" Monsieur Schnaebele inviting him to meet him on the frontier for the purpose of examining a disputed question in regard to a frontier post, and begging him to come unattended.

Count Bismarck admitted that these letters would at first sight throw a suspicion on the code of honour, regulating international relations between colleagues of the police force, as it looked like very unhandsome treatment of Monsieur Schnaebele by his "cher Collègue" on the German side of the frontier.

His Excellency said that he had, however, pointed out to Monsieur Herbette that the Charge against Monsieur Schnaebele was not one of a common offence, but a very serious criminal charge of high treason.

From other sources I learn that there is good reason to believe that Herr Gautsch acted in perfect good faith, and had no knowledge, when he wrote to his French Colleague, inviting him to meet him, that detectives, acting under secret instructions from the Judge at Strassburg, were lying in wait to arrest the French Commissioner on the first occasion of his crossing over the frontier.

\footnotetext{
${ }^{\mathrm{I}}{ }^{2}$ Guillaume Schnæbelé, an Alsatian-born French railway police officer, was arrested for crossing the Franco-German border on suspicion of espionage on 20 April 1887 . He was subsequently released on 28 April.

${ }^{146}$ French: 'self-respect'.

${ }^{147}$ Herbert von Bismarck.

${ }^{148}$ Dated I3 and I6 April I887.
} 
The Strassburg Court, set in motion by the High Court of Justice at Leipzig is understood to have most damning proofs of Monsieur Schnaebele's complicity with treasonable intrigues against the safety of the German Empire. German Courts of justice are excessively jealous of any intervention on the part of the Government with the course of justice in it's earlier stages, hence possibly the delay in furnishing the French Government with the full dossier of the preliminary enquiry into the circumstances attending the arrest, which seems clearly to have taken place on German Soil, although it has been asserted by some that, during the struggle which ensued, the French Commissioner at one time dragged part of his person across the frontier line into French territory.

The general impression however seems to be that Monsieur Schnaebele will be eventually set at liberty, if it is shown that he was treacherously induced to cross the frontier by an invitation to confer on frontier questions with the German official.

There seems to be no ground whatever for suspecting the German Government of being privy to Monsieur Schnaebele's arrest by means of a stratagem, the discredit of which, if proved, would only attach to the subordinates of the police court charged with the arrest.

\section{FO 64/1157: Edward B. Malet to Marquess of Salisbury, Secret, No 192, Berlin, 25 May 1887}

[Received 30 May by messenger. For: The Queen; S[alisbury]]

Bismarck's concerns over ill health of crown prince

I have reported in my Despatch $\mathrm{N}^{\circ}$ igI of today, that Prince Bismarck called upon me yesterday to present his congratulations on the occasion of the Queen's birthday. His principal subject of conversation was the illness of the Crown Prince, ${ }^{149}$ which, he said, caused him deep anxiety, and had prevented him from sleeping at night. He had learnt that the Physicians, who attended His Imperial Highness, prepared to perform an operation of a very serious nature, for the purpose of extracting a growth which was forming itself in his throat, and Prince Bismarck had felt that such an operation ought not to be performed without the sanction of the Emperor, and he was also of opinion that His Imperial Highness should himself be made acquainted with the nature of the operation, to which it was

\footnotetext{
${ }^{\mathrm{I}} 49$ Friedrich Wilhelm had cancer of the larynx. The operation (thyrotomy) was originally scheduled for 2I May, subsequently postponed and ultimately cancelled.
} 
proposed to subject him. He had found it necessary to remind the Physicians that they were dealing with the Heir to the Throne, and that his life was too precious to be considered like that of an ordinary man. Prince Bismarck showed much emotion in speaking on the subject to me. It is now hoped that the operation may prove to be unnecessary and in any case no precaution which art or form can suggest will be neglected.

\section{FO 64/1157: Edward B. Malet to Marquess of Salisbury, No 218, Berlin, 12 June 1887}

[Received I4 June by post. For: The Queen / Prince of Wales; S[alisbury]]

Long and friendly article in Deutsche Allgemeine Zeitung on Queen Victoria's Golden Fubilee; general praise for Britain and her policies

The Semi-official Nord Deutsche Allgemeine Zeitung publishes this morning a long leading article couched in the most friendly tone on the approaching Jubilee of Her Majesty The Queen. ${ }^{150}$

The article commences by saying:

"Within the next few days a festival will be celebrated in a country bound by ties of friendship to our fatherland, which having regard to the term of human life must be acknowledged an uncommon one, but which on other grounds is sure of the lively sympathy of Germany. Our readers will divine that we refer to the $50^{\text {th }}$ Jubilee anniversary of the reign of the Queen of England and will recognize from the fact that His Imperial and Royal Highness the Crown Prince and His Royal Highness Prince William are starting today for London to take part in it, how essential our Ruling house esteems it that the German Empire should be most worthily represented on this festal occasion. It is not only the many ties of blood which have long united the two monarchies, but in a no less degree the kindred origin of the two nations and their common work in the cause of culture and civilisation which will be recognised by the world as finding significant record in the visit above referred to."

The article then goes on to resume the efforts of the last fifty years in England towards internal progress and reform and the energy displayed in remedying social deformities, and expresses the hope that the present crisis in Parliamentary development ${ }^{151}$ will be brought to as satisfactory an issue. It glances rapidly over the history of

\footnotetext{
${ }^{150}$ The $50^{\text {th }}$ anniversary of Victoria's accession as queen was on 20 June 1887.

${ }^{151}$ The Norddeutsche Allgemeine Zeitung was alluding to the unresolved question of 'Home Rule' after the rejection of the Government of Ireland Bill in 1886.
} 
Englands more important colonies and concludes that Her Majesty's reign has witnessed the firm establishment of our colonial empire under a high principled administration.

The article concludes with these words.

"We can only hope that the bond, founded on the mutual confidence of the two Governments in one another, which derives yet stronger support from the union of the Princess Royal of England $^{152}$ with the Prussian Prince Frederick William, will be upheld in the future, and we take this opportunity of expressing the feelings of sympathy which the German nation offers especially at this moment to the British Empire, and the liberal recognition which we pay to the achievements of the English national spirit, by wishing the Royal Lady who rules over Great Britain many more years to dispense the blessings of her reign to her people.["]

\section{FO 64/1158: Charles S. Scott to Marquess of Salisbury, No 261 , Berlin, 9 July 1887}

[Received II July by messenger. For: The Queen / Prince of Wales; Qy: Print (Western Europe) / Embassies / Intelligence Department; S[alisbury], I3 July]

Treason trial at Leipzig; feelings among German press and public towards France

I have the honour to transmit herewith a short summary by $\mathrm{M}^{\mathrm{r}}$ Lister of the Newspaper Reports of a further remarkable treason trial which has been taking place this week before the High Court of Leipzig. ${ }^{.53}$ This Summary gives very fully the remarks of the Public Prosecutor ${ }^{154}$ when stating the case for the Crown, and these will be found to constitute a very open and serious charge against the French Government.

This trial has a special interest, as being intimately connected with the recent arrest of the French Commissaire de Police, Schnaebele. ${ }^{155}$

Although, as Your Lordship has already learnt from the reports of the Military Attaché to Her Majesty's Embassy, Colonel Swaine, the German War Office has for many months past been in possession of facts clearly showing that a wholesale system of 'Spionage' has for some years been going on in the Western frontier of France, under

\footnotetext{
${ }^{152}$ Victoria.

${ }^{153}$ The trial against three citizens from Alsace-Lorraine took place from 4 to 8 July. Two defendants, Tobias Klein and Martin Grabert, were sentenced to imprisonment for five and six years respectively; the third was acquitted. Enclosure: memorandum on treason trials at Leipzig, 9 July 1887.

${ }^{154}$ Hermann Tessendorf.

${ }^{155}$ For the Schnæbelé incident see pp. $83-84$.
} 
the direction of the French War Office, the General public was, until very lately, not aware of the manner in which this system was being carried on, or of the extent of the danger to which the Empire was exposed.

There were consequently to be found, even in Germany, a few persons and newspapers to maintain that the German Government had attached unnecessary importance to rumours of hostile designs on the part of General Boulanger, and to the agitations of the French patriotic League.

The Revelations made in the Course of this trial, appear to have completely dissipated these doubts, and judging from the present tone of the German press of all shades and colours it would be difficult to exaggerate the prevalent feeling of general irritation and indignation directed not so much against the Alsatian spies who have fallen into the clutch of German justice, but against the French Government, who instigated and employed them.

It is argued that most military Governments have their Intelligence Departments, and are often obliged to have recourse to Secret sources of information, but that the system which the French Government has been employing - using officials of the War office, and of the Ministry of the Interior (such as the frontier police who are entitled to claim special confidence from the neighbouring state) to seduce German subjects from their allegiance, and to employ them as paid spies against their country is unparalleled in the history of the relations between two States in time of peace.

In alluding to this trial yesterday, Count Bismarck ${ }^{156}$ spoke very strongly, and very much in the above sense; - he said that Monsieur Herbette had naturally not ventured to allude to the subject in conversation with him and he could not conceive how the French Government could justify their action even in their own eyes.

His Excellency said that the German Government had been forced to court the utmost publicity for the Leipzig trials, by the tone and temper of the French press and public when commenting on the Schnaebele incident and the trial of the Members of the Ligue Patriotique. ${ }^{157}$

Not only in the French press, but in other quarters unfriendly to Germany, efforts have been persistently made to represent Germany as endeavouring to provoke a quarrel with France, and irritating her by unnecessarily persecuting French sympathizers in

\footnotetext{
${ }^{156}$ Herbert von Bismarck.

${ }^{157}$ The trial against members of the Ligue Patriotique (a nationalist league founded in I882) took place from I3 to I8 June at Leipzig and led to the conviction of four of the eight defendants (all from Alsace Lorraine).
} 
Alsace Lorraine; it was therefore absolutely necessary to show the world at large the extent of the danger to which the German Empire had been exposed for some time past, and the manner in which the French Government employed their frontier officials in time of peace.

The feelings of the German public towards France have not been improved by hearing of the proposals in the French Chamber to adopt so-called measures of retaliation against German residents in France and the Norddeutsche Allgemeine Zeitung commenting this week on the proposal to levy a tax in lieu of Military Service on foreigners in France, not only contests to the legality of such a measure, but utters a distinct warning that Germany may at last lose patience, and be obliged to recur to severe measures of retaliation against French subjects especially in Alsace Lorraine. ${ }^{15^{8}}$

Count Bismarck, with reference to this subject told me that the Commercial Treaty Engagements of Frankfort ${ }^{59}$ clearly prevented the French Government from levying any tax from Germans not similarly imposed on French subjects.

I have thought it my duty to report the state of feeling produced here by the trial of Klein and his associates - taken together with the feeling which the Leipzig trials appear to have evoked in France, the situation would, under ordinary circumstances, appear so serious as to justify alarm for the relations between the two Countries, but at present no apprehension of serious consequences appears to be entertained here.

The whole German press appears to be unanimous in regard to the necessity of treating the Anti-German outbursts of the French Chamber and public with the same calm indifference as the German Foreign office.

As one German Newspaper puts it, the only guarantee that we possess for the preservation of peace between the two countries is the firm conviction on both sides that a fresh appeal to arms could now only terminate in the complete extinction of one or other of the two combatants, but this guarantee is a very solid one, and will doubtless have the desired effect.

\footnotetext{
${ }^{15}{ }^{8}$ The tax on foreign residents in France - on which the Norddeutsche Allgemeine Zeitung commented on 6 July - was discussed in the committee of the French chamber of deputies. It was proposed that foreigners pay a tax comparable to the fee for exemption from military service for French citizens.

${ }^{159}$ Bismarck was referring to Article II of the Treaty of Frankfurt of io May i87i.
} 


\section{FO 64/1158: Charles S. Scott to Marquess of Salisbury, Confidential, No 273, Berlin, I6 July 1887}

[Received I8 July by messenger. Print (Western Europe). For: The Queen / Prince of Wales / Mr W.H. Smith / Embassies / Eastern Department (last paragraph); S[alisbury], I8 July]

Boulanger's noisy departure from Paris increases public anxiety about Franco-German relations; German political attention focused on France at expense of Eastern Europe

The Paris telegrams of yesterday morning reporting that the Fête of the $14^{\text {th }}$ had passed off without serious disturbance or incident have caused a very general feeling of relief here, for it is impossible to disguise the fact that the past week at Berlin has been one of very grave anxiety and suspense.

As I had the honour to report in my Confidential Despatch $\mathrm{N}^{\mathrm{o}}{ }_{26} \mathrm{I}$ of the $9^{\text {th }}$ instant, I understood that, notwithstanding the bitter feelings aroused in both countries by the late Leipzig trials, ${ }^{160}$ serious apprehensions of immediate danger were not entertained here, as the recognized gravity of the situation was in itself a guarantee that no rash step would be taken on either side.

When, however, the news of the disorderly scene at General Boulanger's departure from Paris, and of the inaction or impotence of the French authorities on that occasion reached Berlin, a great change took place in public feeling, and the possibly exaggerated reports of the occurrences sent to the local press by their Paris Correspondents, caused very real alarm both on the Berlin exchange and among the General public, and this alarm was not allayed by the appearance of warnings of danger in organs generally credited with official inspiration, such as the Norddeutsche Allgemeine Zeitung, Post and other papers. ${ }^{161}$

Count Berchem told me yesterday that the German Foreign Office had been so absorbed by the gravity of the situation in France, that he had paid but little attention to what was going on in the East of Europe: he felt however that as the French Government had shown their ability to cope with the party of disorder on the $14^{\text {th }}$, and had gained a decided victory over the Radical Section of the Chamber, serious apprehension might be dismissed for the present. ${ }^{162} \mathrm{He}$

\footnotetext{
${ }^{160}$ See the preceding dispatch.

${ }^{161}$ Boulanger who, to the embarrassment of the French government had polled Ioo,ooo votes in the Seine by-election despite not being a candidate, was appointed commander of an army corps in Clermont-Ferrand (on 28 June). About Io,ooo of his supporters tried to prevent the departure of his train from Gare de Lyon on 8 July.

${ }^{162}$ Berchem was referring to the preventive measures which had been taken against demonstrations in support of Boulanger on $\mathrm{I}_{4} \mathrm{July}$, and the failed interpellation regarding
} 
admitted, however, that the situation, after the demonstration at the Lyons railway station, had been very alarming.

It was, he said, just possible that the French Government may have acted wisely in allowing the outburst to waste it's force on this occasion, instead of at the Military Review, where the consequences might have been more serious, and, in fact, it seemed as if the Boulanger party had lost instead of gaining ground by their demonstration.

'At all events', he added, 'let us hope that things will remain quiet at least till the Autumn.'

I may add that among the reports from Paris, which caused most alarm, was one stating, on what professed to be high authority that Panslavist agents had been the chief instigators of the Boulanger demonstration, and that their object was to provoke a war between France and Germany, as Russia was only waiting to move in the East, until Germany was seriously occupied in the West of Europe.

\section{FO 64/1158: Gharles S. Scott to Marquess of Salisbury, No 298, Berlin, 6 August 1887}

[Received 8 August by messenger. Copy. Qy: 'Admiralty for observations'; Adm [iralty], Io August; S[alisbury], 8 August]

\section{Diffculties in obtaining information about German naval manoeuvres near Danzig}

In compliance with the instructions of Your Lordship's Despatch No: 339 of the $18^{\text {th }}$ ultimo, I have been endeavouring to obtain as much information as possible with regard to the German Naval Manoeuvres now going on in the Baltic off the Coast of Dantzig. ${ }^{163}$ I have also instructed $\mathrm{M}^{\mathrm{r}}$ Consul Hunt at Königsberg, whose Consular District includes Dantzig, to supply every information in his power, and I shall eventually have the honour to report as fully as I can to Your Lordship.

In the meantime, I would venture to point out to Your Lordship the difficulty which $\mathrm{M}^{\mathrm{r}}$ Hunt and I experience in carrying out Your Lordship's instructions.

The German Admiralty are, I understand, desirous that the greatest part of these naval manoeuvres, and probably that very part, which would be most interesting to Her Majesty's Admiralty, should be kept secret from Foreign Powers, and I presume that Your

the government's general attitude and its position towards the royalist and clerical movements on ir July i887.

${ }^{163}$ Naval manoeuvres in the Baltic took place until mid September. 
Lordship would not wish Her Majesty's diplomatic and Consular officers in Germany to expose themselves to the charge of employing secret means to obtain the desired information.

The British Vice-Consul at Dantzig, $\mathrm{M}^{\mathrm{r}}$ Durège, although I believe recently naturalized as a British Subject, is a German by origin, and for other reasons I should doubt the propriety of entrusting to him the duty of collecting the information in question.

Königsberg being at a considerable distance from the scene of them, $\mathbf{M}^{\mathrm{r}}$ Hunt does not seem to think that it will be possible for him to supply much valuable information to the Admiralty.

I therefore fear that my Report will have to be confined to the reports of the Manoeuvres which are given in the local press and to any information which I may be able to pick up from private friends, eyewitnesses of the manoeuvres from the shore.

\section{FO 64/1159: Gharles S. Scott to Marquess of Salisbury, No 36o, Secret, Berlin, 30 September 1887}

[Received 3 October by messenger. For: The Queen; Qy: Print (Western Europe); Secret to: Embassies, P.L. [printed letter], 8 October / War Office / Intelligence Department; Prince of Wales; S[alisbury], 6 October i887]

Franco-German tension increased by border incidents; military attaché's concerns about possible confict; diplomatic view of continued peace

I have the honour to forward herewith to Your Lordship a Secret Memorandum referring to the dangers of a possible conflict between Germany and France, which has been submitted to me by Colonel Swaine, Military Attaché to Her Majesty's Embassy, in continuation of the information forwarded by Sir E. Malet in His Excellency's despatch number 328 of the $3^{\text {rd }}$ instant. ${ }^{.64}$

Colonel Swaine, as Your Lordship will perceive, takes a rather alarming view of the present situation in the West, and indicates certain military preparations and strategical considerations which give colour to a surmise that the German Military Authorities would prefer that a war with France, if inevitable, should be brought about in the coming winter.

This military view of the situation is one which should certainly not be lost sight of, but at the same time I understand that in the highest

\footnotetext{
${ }^{164}$ Swaine's memorandum of 3 September 1887, enclosed in Malet's No 328, dealt with the German War Office's plans to order I,ooo large huts which would provide accommodation for an additional 50,00o men. According to Swaine's secret memorandum of 26 September (enclosure to No 360 ) this number was raised to 2,00o huts.
} 
diplomatic and political quarters here a much more sanguine view of the prospects of peace is generally entertained.

It is admitted that the recurrence of irritating frontier incidents, ${ }^{165}$ and the ferment which these have naturally provoked in the minds of the populations on both sides of the frontier, have made the situation somewhat a critical one, and that the maintenance of peace is at the mercy of any untoward event, but fresh confidence has been inspired here by the more moderate views prevailing in the present French Cabinet and by the repeated assurances of the German Foreign Office that no effort will be spared to avoid wounding French susceptibilities, and that it is not only the desire but the interest of Germany to refrain from giving the slightest provocation to France.

On the other hand, if the French Government were induced by overweening confidence in the success of their late experiment at mobilization, ${ }^{166}$ to take any action on the frontier such as Colonel Swaine has indicated and a rumour of such an intention has, I believe, already reached the German Foreign Office - there can be no doubt but that it would be promptly met by some German counter move, and the dangers of the situation would be greatly increased. Moreover, if it was clearly established here that a war with France was inevitable and impending in a near future, the general consensus of opinion is that even the ardent desire of the Emperor and Prince Bismarck for the maintenance of peace would give way to the general desire to secure that the conflict should take place under the most favourable conditions possible to Germany.

While venturing to submit to Your Lordship the impression which I find prevalent in diplomatic quarters here on the subject touched on in Colonel Swaine's Memorandum, I may mention the fact that the Austrian Chargé d'Affaires ${ }^{167}$ told me a few days ago in confidence that he had observed in the last despatches from the Austrian Ambassador at $\mathrm{S}^{\mathrm{t}}$ Petersburg which had passed through his hands on their way to Vienna, that Count Volkenstein [sic] had reported a conversation with Monsieur de Giers, in which the latter laid stress on the greater dangers to peace in the West of Europe, and, had observed that it might be impossible for the Emperor

\footnotetext{
${ }^{165}$ A border incident occurred near Raon-sur-Plaine on 24 September 1887 when a German soldier fired at a French hunting party; a servant was killed and an officer severely wounded. See also pp. 83-84 and 86-88.

${ }^{166} \mathrm{Scott}$ is referring to the test mobilization of the Seventeenth Army Corps, which was conducted in Toulouse on I September I887.

${ }^{167}$ Arthur Ritter von zu Eissenstein-Chotta.
} 
and himself to withstand a popular cry for action by Russia, when the inevitable and impending conflict between Germany and France broke out. I observe that Sir R. Morier reports that Monsieur de Giers has held very similar language to him, and it is probable that Monsieur de Giers has derived his apprehensions from military information received from Berlin similar to that supplied by Colonel Swaine.

\section{FO 64/1159: Edward B. Malet to Marquess of Salisbury, Confidential, No 405, Berlin, 29 October 1887}

[Received 2I October by messenger. For: The Queen / Prince of Wales / Confidential to Embassies in M.S.; S[alisbury], 30 October]

Deterioration in relations between Germany and Russia; tsar's probable visit to the emperor

I enquired of Count Bismarck ${ }^{168}$ yesterday whether there was now reason, to suppose that the Emperor of Russia would visit the Emperor of Germany. His Excellency replied that no communication on the subject had, as yet, reached the German Court, but that it looked, at present, as if the Czar would be compelled to go back to Russia through Germany and that in that case it was almost natural that His Majesty should pay a visit to the German Emperor; indeed it was difficult to arrange the journey with the necessary comfort without the Imperial train passing through Berlin. ${ }^{169}$

According to the latest advices the Czar, he said, would not leave Copenhagen before the $16^{\text {th }}$ of November.

I gather that such a visit would be regarded rather as an embarrassment than as a satisfaction, but that it is looked upon now as almost unavoidable unless the Czar should himself take the measles which would give His Majesty a valid excuse for not coming to see the Emperor of Germany although passing through his dominions.

The general relations between Germany and Russia grow less and less cordial, and it is not desired here that the effect produced by the alliance between Germany and Italy should be in any way diminished.

\footnotetext{
${ }^{168}$ Herbert von Bismarck.

${ }^{169}$ Alexander III had been staying in Denmark since 26 August. On his return journey to Russia he visited Berlin, on I8 November I887.
} 


\section{FO 64/ir6o: Edward B. Malet to Marquess of Salisbury, Very Confidential, No 442, Berlin, 19 November 1887}

[Received 2i August by messenger. For: The Queen / Prince of Wales / Cabinet / Copies to: Embassies (M.S.); S[alisbury], 22 August]

Count Bismarck's conversation with General Cerevin about European uneasiness at Russia risking European peace; no secret alliance between the two countries

Count Bismarck informed me today that the Chancellor ${ }^{170}$ had had a long interview with the Emperor of Russia yesterday and that he, Count Bismarck, had spoken at length on the general situation to General Tcherévin, who was in attendance on the Emperor, and was one of the few people who enjoyed His Majesty's Confidence, and was in a position to tell His Majesty the truth. ${ }^{{ }^{77}}$

Count Bismarck said that he used to him the same language which he had used to Count Shouvaloff, ${ }^{172}$ as related in my Despatch No: $4 \mathrm{I} 4$, of the $5^{\text {th }}$ instant, and had gone on to say that the uneasiness at present felt throughout Europe with regard to the future was directly attributable to Russia, and that it lay with Russia to appease it. The French, he said, were only courageous because they believed that they had Russia at their back. The "Revanche" balloon inflated by Russian Gas. If Russia allowed it to be known that she had no intention of coming to the assistance of France, if she would withdraw her troops from her Western Frontier, if the Emperor would forbid the Russian press to indulge in calumnies against foreign nations, all insecurity would instantly pass away and Europe would be able to breathe; Commerce would progress and prosperity return.

The alliances which had been formed in Central Europe were only designed to preserve peace: there was not a Power in Europe about whose intention to maintain peace, a doubt could be entertained except Russia and France, and France, if she no longer had hope of Russian aid, would be completely powerless. Treaties prevented her from attacking Germany, Austria or Italy without engaging all three. ${ }^{174}$ England was equally safe from her because Germany could not permit the diminution of her power.

${ }^{170}$ Otto von Bismarck.

${ }^{171}$ Alexander III visited Berlin on 18 November I887.

${ }^{172}$ In his conversation of I November I887.

${ }^{173}$ French: 'revenge'.

${ }^{174}$ Herbert von Bismarck was referring to the Triple Alliance between Germany, Austria-Hungary and Italy of $\mathrm{I}_{82}$ (renewed in February I887). It pledged Austro-German support for Italy in the case of an attack by France. 
Russia had at present forfeited the confidence of Germany - for a hundred years the two Countries had been in friendly alliance, but of late Russia had thrown all these pleasant traditions to the winds, had only sought to vilify her and misinterpret her motives.

The result was a drawing together of the other Powers, who no longer felt confidence in Russia's policy, and it was only by a complete change of front on the part of Russia, that confidence could be restored.

Count Bismarck said to me that he was able to speak thus frankly to General Tcherévin because he had known him very intimately before in Russia. ${ }^{175}$

The General had listened with attention, and had promised to use such influence as he possessed with the Czar in the direction indicated. Count Bismarck said that the Chancellor had spoken in the same sense to the Czar, though, perhaps, not with the same bluntness and want of form, and that His Majesty had given him the most pacific assurances as to the future, so far as regarded Russia - but Count Bismarck remarked that time only could show what these assurances were worth, and he recalled the saying that the road from the Caspian to Merv was paved with Russian assurances.

He said finally that he wished to give Your Lordship the assurance through me that no understanding, agreement or arrangement of any kind had been come to on this occasion, and he summed up by saying that not withstanding all that Prince Bismarck had urged and all that the Emperor had replied, the feeling of confidence in the future which had been destroyed by Russian action was not in any particular degree restored by the Imperial Visit, although, as between the two Sovereigns, it has been most cordial and affectionate.

\section{FO 64/in 86: Edward B. Malet to Marquess of Salisbury, No 86, Berlin, 15 March 1888}

[Received i9 March by messenger. For: The Queen / Prince of Wales / Circulate; S [alisbury], Io March]

Friedrich III's imperial rescript and address to the people; analysis of press responses - generally very favourable

In my despatches $\mathrm{No}^{\mathrm{s}} 22$ and 23 Treaty of the $13^{\text {th }}$ instant, I had the honour to transmit to Your Lordship copies and translations of The

\footnotetext{
${ }^{175}$ Herbert von Bismarck - while retaining his post as first secretary in London - was attached to the embassy at St Petersburg from January to May I884.
} 
Emperor Frederick's address to his people, and of the Imperial Rescript addressed to the Chancellor. ${ }^{176}$ These documents, and more especially the latter which is fuller in detail, and which I was informed by Prince Bismarck himself was entirely composed by the hand of His Majesty, have evoked expressions of the most lively satisfaction from the Press of all shades of opinion. Journals of the most opposite tendencies have joined hands in approving them, and the chorus of appreciation is not merely such as might naturally be prompted by consideration for the trying position of the new Sovereign, but bears the stamp of genuine sincerity.

The extreme Conservative "Deutsche Tageblatt" calls the address a most attractive one, calculated to win confidence, and to reach the hearts and sympathies of the Prussian nation and of the whole of Germany no less. The United German nation will respond with gratitude and loyal devotion to the address of the heir of The Emperor William[.] Especial satisfaction is expressed at the confidence reposed by His Majesty in the Imperial Chancellor, a confidence which indicates the lines his policy will follow.

Similarly the "Conservative Correspondenz" welcomes the assurance given that the Imperial Government will continue to work in the lines in which the Prussian State has been developed. It dwells on the Conciliatory attitude adopted towards the various shades of religious thought, and notices with satisfaction the encouragement promised to Art and Science.

The "National Zeitung", a journal of liberalist tendency, and generally considered to represent the views of the financial party, says that the two documents will make a deep impression throughout Germany, and convince the world that The Emperor William has been succeeded by a Prince who looks upon it as his first duty to maintain peace and prosper the arts of Peace. The substance of the two documents may be thus summed up, "First and foremost The Emperor Frederick's programme of peace is animated with a genuine National spirit; it is loyally constitutional; it contemplates no rupture with the former internal policy, but nevertheless its' utterances with regard to internal affairs are characterized by a distinct individuality." Not even The Emperor William could have insisted more imperatively than is here done in the necessity of keeping the defensive forces of the Empire up to their utmost strength. The paragraph in which The Emperor declares he will maintain Universal Tolerance in matters of religion was evidently, the Journal continues,

\footnotetext{
${ }^{176}$ The address and the rescript to Otto von Bismarck are dated I2 March I888; Wilhelm I died on 9 March.
} 
written "con amore" ${ }^{\prime 77}$ and while promising peace to the Catholic Church it administers an implied rebuff to the militant protestants of the school of Herr Stöcker. On points of social, financial and administrative policy, the two documents point to a continuance of tried methods, while they discountenance an undue interference of Government in coping with all social ills. The Programme is a thoroughly moderate one. Anyone who imagined that the Emperor Frederick intended to introduce a system of Government by Parliament will realize his mistake.

The "Börsen Courier" points out that the Rescript Contains a warning against legislative overproduction, and welcomes the principle of religious toleration upheld.

The "Germania", the organ of the Catholic Party, expresses itself in words of warm appreciation, and finds the general constitutional tendency of these utterances best characterized by the clause, requiring a loyal respect for the Rights of the Emperor from all those concerned, in return for the Emperor's guarantee that the rights of the Federal Governments and those of the Reichstag shall be loyally respected by His Majesty.

The semi-official North German Gazette ${ }^{178}$ has hitherto confined itself to collecting the favourable notices published in the contemporary press; but the inspired "Post" and "Cologne Gazette" both recorded their sincere approval; while the "Freisinnige Zeitung" the journal of the radical party, ${ }^{180}$ founded by their leader Herr Richter, says that these two state papers are sure to awake a loyal echo in the German Nation: the Paragraph referred to above by the "Germania", dealing with the mutual confidence which The Emperor and the Federal Governments as well as the Reichstag must repose in one another's loyal observance of the rights of Each, can leave no room for dictatorial ambition, and the promise of absolute religious tolerance is no less satisfactory, it is no party programme and all honest efforts, from every point of view, on behalf of the Fatherland, may hope to win His Majesty's appreciation.

The opinions of the provincial papers, as far as they have yet come in, are in a similar key. The "Hannoversche Courier" rejoices in the fact that The Emperor Frederick will have at His side His Father's faithful Councillor, Prince Bismarck. From Hamburg, from Stettin, from Magdeburg and from the Rhine Provinces, the most appreciative notices are quoted in the North German Gazette, and generally

\footnotetext{
${ }^{177}$ Italian: 'with love'.

${ }^{178}$ Norddeutsche Allgemeine Zeitung.

${ }^{179}$ Kölnische Zeitung.

${ }^{180}$ Deutsche Freisinnige Partei (see n. 3 in this section).
} 
the two first documents which The German Emperor has published to His people have evoked a chorus of approval from the organs of all opinions which is a good augury for the New Reign.

\section{FO 64/i 86: Edward B. Malet to Marquess of Salisbury, Confidential, No ror, Berlin, 6 April 1888}

[Received 9 April by messenger. For: The Queen / Circulate / Prince of Wales; S [alisbury], in April]

Crown prince's speech at a dinner to mark Bismarck's birthday has aroused much public comment

At a banquet which took place at the Chancellor's residence on the occasion of his birthday on the first instant, His Royal And Imperial Highness The Crown Prince ${ }^{\mathrm{r8r}}$ proposed the toast of the evening in a brief speech which has excited considerable comment here. The speech, as it first appeared in the papers here, contained nothing but a metaphor, in which the nation was compared to a regiment, whose commander had fallen, leading the attack. "The next officer", the Prince continued, according to the report first published, "lies severely wounded. In this critical moment forty six millions of loyal Germans turn their eyes to the colours and to their bearer, as to the one on whom all depends. The bearer of this banner is the Prince, our great Chancellor. Let him lead the way, we will follow him. Long live the Chancellor."

This somewhat slighting notice, the only one, as the speech was first reported, of the reigning Emperor, as "the second officer lying severely wounded" gave rise in many quarters to the most lively criticism, and it was soon discernible that these criticisms had reached official ears by the appearance of a paragraph in the Cologne Gazette, stating that the speech had been submitted to and been approved by His Majesty.

This morning, however, the semi-official "Norddeutsche Allgemeine Zeitung" gives as the actual text a somewhat different version of the speech, with a view, it says, to correcting various inaccuracies and omissions in previous reports.

I have the honour to transmit copy and translation ${ }^{182}$ of the text of the speech as given in this morning's North German Gazette. Your Lordship will observe that this version opens with expressions of loyalty and devotion to the Emperor, who in the metaphor of the battle,

\footnotetext{
${ }^{181}$ Wilhelm.

${ }^{182}$ Enclosures: extract (untitled) from Norddeutsche Allgemeine Zeitung and translation, 6 April 1888.
} 
is described as, though wounded, still bravely riding on. It concludes as follows:

"Long may you (the Chancellor) be spared us, that is our heartfelt wish, to hold on high the Imperial banner, at the side of our beloved Emperor - God bless and guard both Him and you."

\section{FO 64/II86: Edward B. Malet to Marquess of Salisbury, No II7, Berlin, I4 April 1888}

[Received 23 April by messenger. Qy: Direct Sir E. Malet to thank German government / Enclosure to War Office and inform ${ }^{183}$; S[alisbury], 23 April; Drafts Sir E. Malet \& War Office, 26 April]

Press opinions on chancellor crisis; press notification that Queen Victoria supports Bismarck's viewes of the inappropriate union between Princess Viktoria of Prussia and the former Prince of Bulgaria

The political storm which is termed by the Press "The Chancellorcrisis" has filled the newspapers during the week and has been dealt with by them according to their respective political leanings without much regard to fact in any quarter. What is termed the inspired Press has taken side with the Chancellor while the opposition sheets blame him and ask for his retirement.

It seems to be generally agreed that the conflict has passed out of it's acute phase, and that the project of marrying Princess Victoria of Prussia to Prince Alexander of Battenberg has been either abandoned or postponed. ${ }^{184}$

On the whole I am inclined to think that the Chancellor's reputation has been tarnished by the manner in which he has conducted the campaign or at all events has allowed the battle to be fought. It is well known that the newspapers which support the Government are so far practically under control that when they take a line, they do so from official inspiration. These newspapers have teemed with paragraphs indirectly attacking The Emperor and dragging in the name of The Queen.

\footnotetext{
${ }^{183}$ No enclosure in FO 64/1186.

${ }^{184}$ Princess Viktoria and Alexander of Bulgaria became engaged in $188_{3}$. Despite dynastic and diplomatic objections concerning German relations with Russia, the marriage plan was renewed after Alexander's abdication as Prince of Bulgaria, in I886, and again after the accession of Friedrich III. The matter was brought to public attention in April I888 by newspaper articles which were largely directed against the German Empress, Victoria, who supported the marriage. The Kölnische Zeitung of 5 April, on the other hand, reported of rumours of Bismarck's resignation.
} 
Prince Bismarck must look for approval for this method of warfare to those who are compelled to support him from interested motives, for none who are chivalrous or loyal can uphold it.

I am glad to say that a contradiction of the rumour that The Queen advises the Marriage, is now going the round of the Press. It is much to be regretted that Her Majesty's name should ever have been mentioned in the matter, but it was shameful that, without a shadow of foundation, a course of action should be ascribed to Her Majesty which might have envenomed public feeling against Her on the Eve of Her Majesty's projected visit to Berlin. ${ }^{18.3}$

The following appears in this morning's edition of the National Gazette: ${ }^{186}$

"The Berlin correspondent of the Press [sic] Correspondence ${ }^{187}$ writes as follows: Queen Victoria will come at the end of this month to Berlin. We are assured by well informed persons that, in opposition to the view generally propagated, The Queen of England is entirely on the side of the Imperial Chancellor in the question of the opportuneness of a marriage between Her Grandchild and the former Prince of Bulgaria, and fully realizes the force of the objections which are raised against this marriage from a political point of view! We reproduce this communication, the correctness of which it is difficult to control, because it is clearly being spread intentionally, and has found its way into a great number of newspapers".

\section{FO 64/1186: Edward B. Malet to Marquess of Salisbury, No I24, Berlin, 28 April 1888}

[Received 30 April by messenger. For: The Queen / Prince of Wales / Circulate; S[alisbury], I May]

\section{Success of Queen's visit to Berlin; Battenberg affair}

There is no doubt that The Queen's visit to Berlin has been a political success. ${ }^{188}$

The circumstances, under which Her Majesty's journey was undertaken, had induced a vague apprehension that it might be

\footnotetext{
${ }^{185}$ Queen Victoria was expected to visit Berlin on her return journey from Italy, and did so from 24 to 26 April 1888 .

${ }^{186}$ National-Zeitung, I4 April I888.

${ }^{187}$ Politische Korrespondenz (semi-official news agency from Vienna). The name of the correspondent is not traceable.

${ }^{188}$ Victoria visited Berlin from 24 to 26 April 1888.
} 
more prudent for Her Majesty not to come. Acting on a complete misapprehension with regard to the attitude of Her Majesty in connection with an anticipated betrothal of Princess Victoria of Prussia to Prince Alexander of Battenberg, the portion of the press which is supposed to write in accordance with inspiration from the Government had denounced foreign influence in the internal affairs of Germany and although the fundamental Error of the argument had been almost officially exposed, the flood of insolent writing which had been let loose did not quickly subside, and it was feared that the greeting which might await Her Majesty on arrival would not be cordial and that, on this account, the feeling between England and Germany already somewhat estranged through misrepresentations of the Press might be further embittered.$^{189}$ It is therefore with no common degree of satisfaction that I am able to record that the exact reverse has taken place. The breach, such as it was, has been closed not widened. The hearty cheers with which Her Majesty was greeted by dense crowds during her drive through Berlin, proved how little effect the venom of the Press had upon the people, and the general feeling with regard to the result of the visit is that it has done great and, it is to be hoped, lasting good.

I may say that this view is shared by many with whom I have spoken, of whom it cannot be said that their opinion is the result of the wish being father to the thought.

It is believed that the interchange of personal communication of The Queen with The Empress Augusta, The Crown Prince, ${ }^{190}$ and Prince Bismarck, has been of the highest value in freely brushing away industriously woven cobwebs, and the spiders, of which unfortunately there are too many, have had to retire to their holes.

Prince Bismarck has openly expressed the great satisfaction which he derived from his Conversation ${ }^{191}$ with The Queen, and has said that if the action of England should correspond with the sound sense and practical character of the views held by Her Majesty, the danger of a European War would be minimised.

The graceful tribute to the Queen, which appeared in last night's North German Gazette of which I have the honour to enclose a copy and translation, ${ }^{192}$ is a fitting Epilogue to the Royal Visit, which has ended so happily and shown that good will and cordial relations

\footnotetext{
${ }^{189}$ This refers to the 'Battenberg affair', on which see preceding dispatch.

${ }^{190}$ Wilhelm.

${ }^{191}$ On 25 April 1888.

${ }^{192}$ Enclosures: original (untitled cutting), Norddeutsche Allgemeine Zeitung, 27 April I888 and translation.
} 
between England and Germany are once more the order of the day with the inspired Press.

\section{FO 64/1187: Edward B. Malet to Marquess of Salisbury, Confidential, No r39, Berlin, I I May 1888}

[Received I4 May by messenger. For: The Queen / Prince of Wales / Print (S.E. Europe) / Embassies; S[alisbury], I4 May]

Storm in German press over new foreign loan for Russia; Bismarck intends depreciation of Russian credit even if German interests affected

I have the honour to acknowledge the receipt of Your Lordship's Despatch No: I3o, Confidential, of the $9^{\text {th }}$ instant, transmitting to me a copy of Lord Lytton's despatch No: 278 Confidential of the $4^{\text {th }}$ instant, respecting rumoured negotiations for a loan between Russia and the Comptoir d'Escompte of Paris. ${ }^{193}$

In connection with this subject, the recent reopening of the attack on the financial credit of Russia by the Cologne Gazette and other Organs of the German Press, generally considered to be in touch with official views, deserves attention.

The real secret of this onslaught of the press appears to be a desire on the part of Prince Bismarck to put every possible difficulty in the way of Russia obtaining a fresh loan in the Money markets of Europe, so long as there is any fear of such a financial reinforcement being employed to the detriment of European peace.

I learn from Herr v. Bleichröder confidentially that although it is quite true that the Comptoir d'Escompte offered to negotiate a loan with the Russian Government, the terms of the offer were such as no Power, having a regard for it's financial dignity could entertain. The Comptoire d'Escompte proposed to take up only one fifth of the loan itself, and intended to offer the remaining four fifths for subscription in the public market.

As long as Herr v. Bleichröder of Berlin, who took up the last loan for Russia, ${ }^{194}$ does not feel himself at liberty to undertake a fresh one, it is quite certain that Mess ${ }^{\mathrm{rs}}$ Rothschild $^{195}$ will not come forward, because it is known that Herr Bleichröder's attitude is guided by the will of the Chancellor.

\footnotetext{
${ }^{193}$ Negotiations for a loan of 500 million roubles were entered into at St Petersburg in early April I888. A smaller loan of I25 million roubles was finally agreed on in November I888 between the Russian government and a French-led bank syndicate.

${ }^{194}$ In 1885 as part of an international consortium.

${ }^{195}$ N.M. Rothschild \& Sons.
} 
Were it not for the political objections to a new Russian loan, the German Money Market has more direct interest than any other foreign country in keeping up the financial credit of Russia as long as that Empire contains any element of solvency. In spite of the panic caused here by the first attack on Russian Credit in the inspired press, the amount of Russian stock still held in this country is enormous, the bulk of it being held by the very numerous class of small Capitalists.

Moreover, agricultural interests in Germany, already in a very depressed condition, have sustained a serious additional blow from the reduction of the exchange value of the rouble which has caused the German Grain market to be overflooded with Russian produce.

The 'Börsen Courier", a paper professing to give the impressions of the Berlin Money Market, has recently been at some pains to restore confidence in Russia's credit by an attempt to refute, on the authority of figures which it pronounces to be absolutely trustworthy, a recent assertion of the 'Cologne Gazette' ${ }^{196}$ that unless Russia can raise a new foreign Loan, she will within a measurable distance of time, be unable to provide the requisite amount of gold to meet the annual interest on her foreign loans payable in that currency.

The same paper also expresses its' conviction that the next Russian loan will be effected in Germany, but only when Russia has given solid hostages to peace.

I understand that Prince Bismarck is quite aware of the injury which the depreciation of Russian Credit is doing to important interests in this country, but that his invariable reply to representations on this score is that the maintenance of European peace is the paramount interest of Germany at present, and that private interests whether of investors or of landlords must give way to it.

A point which should also be noted is that the policy of Prince Bismarck with regard to the alliance of the Central Powers is assisted by the depreciation of Russian Credit. The Italian Ambassador ${ }^{197}$ tells me that he considers that the maintenance of the value of Italian 'Rentes' has been mainly due to their purchase in Germany by investors who have sold out of the Russian funds, and this view is also applicable to Austrian Securities.

\footnotetext{
${ }^{196}$ Kölnische Zeitung.

${ }^{197}$ Eduardo de Launay.
} 


\section{FO 64/1187: Edward B. Malet to Marquess of Salisbury, Secret, No 207, Berlin, I4 July 1888}

[Received i6 July by messenger. For: The Queen / Prince of Wales; Secret to: St Petersburg / Vienna / Constantinople; S[alisbury]]

Remarks on general state of affairs and Bismarck's position following deaths of Wilhelm I, Friedrich III and accession of Wilhelm II; importance of emperor's friendly feelings towards England

Before quitting Berlin on leave of absence, I venture to lay before Your Lordship some remarks upon the altered state of things consequent on the deaths of The Emperors William and Frederick and the Accession of The present Emperor. ${ }^{198}$

In the month February i885 The Emperor William's health was waning and Prince Bismarck spoke to me about his own position in the event of His Majesty's decease. He said that when this occurred he should retire into private life, that it had taken him twenty years to obtain His Majesty's confidence and that at the age at which he had himself arrived he had neither the inclination nor the strength to go through the same labour again with a new master. I remarked that I thought that he would find that, whether he wished it or not, it would be impossible for him to relinquish his post and that he could surely count upon The Crown Prince's confidence. He replied that that was not the case: No doubt The Crown Prince would retain him in his post at the beginning of his reign but, "if ever I make a mistake, and we all do that, I should not be able to count upon his support. My methods of Government may be old fashioned, perhaps they are out of date, but I am too old to go to school again and to learn other systems. The unity between my Master and me would cease. It is better that I should forestall this situation. The best thing that could happen to me would be that I should be shot by some assassin when The Emperor dies."

The melancholy circumstances ${ }^{199}$ under which the Emperor Frederick came to the throne prevented Prince Bismarck from carrying out the intention which he thus announced to me, but, although the reign only lasted three months, it was long enough to prove the accuracy of the Chancellor's judgment in regard to his own position. It is certain that if the reign had continued, and The Emperor had been in the enjoyment of good health, the Chancellor would not have retained his post many months.

\footnotetext{
${ }^{198}$ Wilhelm I died on 9 March; Friedrich III died on I5 June I888 and was succeeded by Wilhelm II.

${ }^{199}$ Malet is referring to Friedrich's advanced stage of cancer of the larynx.
} 
In saying that he had gained the confidence of The Emperor William, he did not exactly express the situation. He would have been more precise if he had said that it took him twenty years to gain the mastery over his Sovereign. Prince Bismarck's is not a character in which one can place confidence as we accept the term. The Emperor may have had confidence in his intellect, his foresight, his relentless perseverance and his patriotism, but The Emperor himself was high minded[,] chivalrous and disinterested and the lack of these qualities in the chancellor must have prevented mutual confidence in its best sense. The stronger nature only gained the upper hand.

The Chancellor therefore, foresaw that a similar struggle waited him on the accession of The Emperor Frederick who inherited all His Father's finer qualities in a higher degree and stimulated to vigour and intensity by the intellect of his wife. ${ }^{200}$

The scene has changed: A young Prince has come to the throne, and I have only touched upon the past in order to impress the point that the power of Prince Bismarck is dependent upon the will of The Emperor[.] And that whereas in all the latter years of The Emperor William's reign we had only to consider the intentions of Prince Bismarck, we should now in a considerable measure turn our attention to the Emperor, who has just succeeded.

It has, as Your Lordship is aware, been asserted that $\mathrm{He}$ is anti English in his feelings and that he leans towards Russia. I am anxious to place on record that I believe this assertion to be unfounded. All the straws in the air which I have been able to detect, blow the other way, and, besides straws, I have from Count Bismarck ${ }^{201}$ a positive assurance given by Prince William himself in November last, at a time when the supposed anti-English proclivities of His Royal Highness were the subject of newspaper gossip, that it is not true.

But herein lies a danger: Although His Majesty is nearly thirty years of age, it is not to be supposed that His likes and dislikes are matured, while on the other hand it is probable that events at the outset of His reign may have an enduring influence upon them, and nothing is more calculated to change his feelings with regard to England than the suspicion that all His efforts to show friendliness towards us in the reception which he has given to English Officers, ${ }^{202}$ and other minor matters, which have alone been hitherto within His power, have been unavailing to correct the false impression which has got abroad regarding His views. He is a high mettled Prince, and He has Given His Royal word that we are mistaken. The fear

\footnotetext{
${ }^{200}$ Victoria.

${ }^{201}$ Herbert von Bismarck.

${ }^{202}$ On 9 July i888.
} 
is that a continued show of want of confidence in him at this especial period of his life may produce a revulsion of the feelings which have hitherto weighed the balance, that he may renounce the effort to prove himself friendly to England as a task beyond his attainment and cease his friendliness at the same time.

If we were dealing with a country in which the foreign policy was guided by the Government and not by the Sovereign this would be a matter of small moment, but that is not the case, and we already know by unpleasant experience that, although at the present moment the Chancellor's policy is to court the most friendly relations with Her Majesty's Government, we can never feel sure from one day to another how long that policy may continue. It is therefore of special importance that the Emperor should be on our side. His sentiments will count as a strong factor in the policy which may be adopted towards us. The Chancellor's position is no longer as strong as it was during the reign of The Emperor William, and he will have to humour the Young Sovereign in order to maintain his own power.

I do not know that there is any special thing to be done at present, in furtherance of the views which I have ventured to submit, but I believe that much may be effected by adopting a general tone of confidence in The Emperor's friendly disposition towards England and in allowing it to be known that that Confidence exists.

\section{FO 64/1188: Charles S. Scott to Marquess of Salisbury, No 250, Berlin, 18 August 1888}

[Received 20 August by bag. For: Print (Western Europe) / The Queen; S[alisbury]]

Ceremonial unveiling of statue of Friedrich Karl of Prussia; great attention paid to emperor's speeches

The Emperor William on the occasion of unveiling the Statue which has just been erected at Frankfort on the Oder of His late Royal Highness Prince Frederick Charles of Prussia - a ceremony which took place with marked honours the day before yesterday - replied to the speech with which His Majesty's health was proposed by the Ober-bürgermeister of the City ${ }^{203}$ in words which have not failed to create a deep impression.

At the outset of the new reign every public utterance of the young Emperor is seized upon as an indication for the future and there must always be the risk of attributing a greater importance to the Royal words than they were meant to convey.

\footnotetext{
${ }^{203}$ Mayor Hermann von Kemnitz.
} 
On the present occasion the Imperial speech which is singularly characteristic of the ardent and enthusiastic temperament of the young Monarch, bears every mark of an improvised utterance inspired by the military surroundings and associations of the ceremony.

No authentic official report of His Majesty's words has as yet been published, but I have the honor to enclose copy and translation of the report which has appeared in the "Post" ${ }^{204}$ the best informed of the unofficial daily Papers.

His Majesty alluding to the seriousness of the present time takes occasion to dispel any illusions in regard to the firm determination of Germany never to relinquish an inch nor a stone of the possessions which She has won by her Sword, and indignantly repudiates the suspicion of His Majesty The Emperor Frederick having ever harboured a contrary view.

It is not easy to discover the immediate motive for this last declaration, as The Emperor Frederick's Proclamations on ascending the Throne were clear and unequivocal on this point, but possibly it may have been prompted by certain utterances in the French press, when reviewing the Acts and Character of the late Emperor, and also by a recent allusion in the Belgian "Nord" to the possibility of Germany cementing her friendship with Denmark by the retrocession of North Schleswig. ${ }^{205}$

\section{FO 64/I188: Charles S. Scott to Marquess of Salisbury, Confidential, No 265, Berlin, 31 August 1888}

[Received 3 September by messenger. For: The Queen; S[alisbury]]

Appointment of Bennigsen as Upper President of Hanover; remarks on political state of Germany and role of Junker party

The appointment of Herr von Benningsen [sic], the Parliamentary Leader of the National Liberal Party, to the Post of Upper President of Hanover, the Province which has been the chief scene of his political career and activity, was announced in the

\footnotetext{
${ }^{204}$ Enclosures: original cutting of emperor's speech printed in Post, I8 August I888 and translation.

${ }^{205}$ Le Nord, a Russian controlled newspaper from Brussels, reported on ${ }_{4} 4$ August I888, that, according to the Danish press, a full reconciliation between Denmark and Germany was dependent on a plebiscite in the northern districts of Schleswig (as stipulated in Article 5 of the Peace of Prague of 1866).
} 
Gazette $^{206}$ of the $29^{\text {th }}$ instant, and is regarded here as a significant indication of the principles by which the new reign will be guided.

Although differing on many internal political questions from the Chancellor of the Empire, the eminent leader of the National Liberals has always retained the personal friendship and respect of Prince Bismarck with whom he has lately been staying at Friedrichsruhe $[\mathrm{sic}] .{ }^{207}$

On more than one occasion in the last ten years it has been rumoured that Herr von Benningsen would be given a portfolio in the Prussian Government, but the negotiations always fell through owing, it is said, to marked divergence of opinion in regard to economical questions between the Liberal Leader and the Prussian Premier.

On the questions of national union and defence, Herr von Benningsen has always been a staunch supporter of the Views of the Chancellor, and it was in a great measure due to his instrumentality that the union of the National Liberals with the Imperial and Conservative factions into the so-called Cartel Party was cemented last year and secured the majority in the present Reichstag which passed the recent Army Bills. ${ }^{208}$

At the onset of the new reign the continued existence of this Union seemed for the moment in some danger. The Reactionary or Junker party, represented in the Press by the "Kreuz Zeitung", ${ }^{209}$ discounting in their own favour the prevailing uncertainty as to the personal political bias of the new sovereign, began very prematurely to agitate the question of reforming the Union by the exclusion of the National Liberal element, and of forming a new majority for the Government out of exclusively Conservative elements, the immediate pretext for Union being certain imminent questions in the Prussian Landtag connected with denominational Education. ${ }^{20}$

This party seems to have based its hopes of success on the effects of the heated controversy which ensued on the retirement from office

${ }^{206}$ Deutscher Reichs-Anzeiger und Königlich Preußischer Staats-Anzeiger.

${ }^{207}$ Bennigsen stayed at Friedrichsruh from 7 August I888.

${ }^{208}$ For the army bill (Imperial Military Law) of I887 see n. II9 in this section. The 'Cartel' (Kartell der Ordnungsparteien), a coalition and electoral alliance consisting of the Deutschkonservative Partei (funker party), Freikonservative Partei (Reichspartei), and Nationalliberale Partei, was formed in February 1887.

${ }^{209}$ Neue Preußische Zeitung (Kreuz-Zeitung).

${ }^{210}$ The disputed question of denominational elementary schools was postponed until after the elections of the Prussian Landtag, which were to be held in October and November i888. The suggestions to end the Cartel were made in the run-up to these elections. 
of its chief champion Herr von Puttkamer, during the short reign of The Emperor Frederick, ${ }^{211}$ and by the attempt which was then made to identify that large minded Sovereign with the more extreme views of the Freisinnige party ${ }^{212}$ and with unqualified opposition to the internal policy of the Chancellor.

Possibly also the fact of The New Emperor having, when Prince, devoted himself almost exclusively to regimental and military matters may have induced the Junker party very unjustifiably to associate His Majesty with the extreme political views of His Messroom Associates, of whom a great number are connected with that Party by family ties.

The grounds for their false confidence in His Majesty's support, whatever they may have been, betrayed the Party into overstepping the bounds of common prudence, and we have for the last two months seen the "Kreuz Zeitung" gradually developing more and more reactionary schemes for the new regime.

With scarcely concealed triumph over the pretended discomfiture of hopes built upon the known liberality of view of the Emperor Frederick, the reactionary organ began to hint that the return to office of Herr Puttkamer was only a question of time, and began to interpret according to its own narrower views those passages in The present Emperor's Manifesto to His People ${ }^{213}$ which proclaimed principles of religious and political tolerance similar to those of His Majesty's Royal Predecessor on the throne, and only a few days $\mathrm{ago}^{214}$ it went so far as to openly advocate a renewal of the Anti-Semitic Crusade, and a reversal of the measure which secured the political emancipation and equality of the Jews.

A recent speech $^{215}$ of The Emperor William II in the Chapter of the Knights of $\mathrm{S}^{\mathrm{t}} \mathrm{John}$, of which varying versions have been published, was interpreted as encouraging the presumption that the present sovereign looked to the Junker Party for His chief support.

One version represented His Majesty as saying that in His endeavours to advance the material and moral well-being of His People, "he relied on the support of the noblest part of it, the high nobility represented in that order" - the other version ran "the support of the noblest part of the Prussian Nobility."

The hopes of the Kreuz Zeitung Party have now received a severe shock from the first political appointment of the new reign, which is

\footnotetext{
${ }^{21 \mathrm{I}}$ Puttkammer was dismissed as minister of the interior on 8 June I888.

${ }^{212}$ Deutsche Freisinnige Partei; see n. 3 in this section.

${ }^{213}$ Proclamation of I8 June I888.

${ }^{214} \mathrm{On} 25$ August I888; the author of the article in question was Adolf Stoecker.

${ }^{215}$ Speech at Sonnenberg on 23 August i888.
} 
admitted to have been in a great measure due to the personal initiative of the sovereign, and also by the selection of Herr von Leipziger, the former Upper President of Hanover, for the similar post in East Prussia for which appointment Herr von Puttkamer was supposed to be the favoured Candidate.

The appointment of Herr von Benningsen indicates the continuance of the Cartel Party, and a renewal of confidence in the support of the National Liberals on the part of the Government. It is also an unmistakable reply to the Agitation of the Reactionary Conservatives for the overthrow of the Liberal Leader's political influence in Hanover, and gives colour to a remark which The Emperor William is commonly reported to have recently made to a rising Prussian Statesman, that His Majesty was firmly resolved to know no distinction of political parties among those of his subjects who were animated by patriotism and a desire for healthy national development, and that He would never countenance a reactionary policy, or the Agitation of class against class.

Utterances like these, so thoroughly in harmony with the liberal views of the Beloved Sovereign, whose premature loss this country is now mourning, will be hailed as of good augury for the opening reign by every liberal minded man both in and out of Germany.

\section{FO 64/1188: Edward B. Malet to Marquess of Salisbury, No 276, Berlin, I September 1888}

[Received i3 September by messenger. For: The Queen; S[alisbury]]

Press article accusing Queen Natalie of Serbia of being ill-disposed towards Germany; might have broader political purpose

I have the honour to transmit herewith in original and translation an article from the North German Gazette of last night which, for certain reasons is specially deserving of attention. It relates to the attitude of the German Authorities towards Queen Natalie of Servia when Her Majesty was recently at Wiesbaden. ${ }^{216}$

The Article after imputing to the Queen Natalie unfriendliness to Germany says that it is an old principle of policy that one must be a

\footnotetext{
${ }^{216}$ Enclosures: untitled extract from Norddeutsche Allgemeine Zeitung, io September 1885 and translation. The article was published in response to allegations made by the Russian press. Natalie had stayed in Wiesbaden from I7 May to I3 July I888 when, against her will, her son was sent back to Belgrade upon the request of King Milan. Natalie was asked to leave io hours after the departure of the crown prince.
} 
friend to one's friends and an enemy to one's enemies and that it makes no difference if among the latter there should be Royal ladies with Kingly title "The rule of political duty renders it necessary to allow us no distinction in regard to sex or rank"[.]

There are indications that the Chancellor ${ }^{217}$ is renewing a tilt against feminine influence in politics and that the article which is clearly inspired is intended to be of wider application than to Queen Natalie.

\section{FO 64/II89: William N. Beauclerk to Marquess of Salisbury, Very Confidential, No 315, Berlin, 13 October 1888}

[Received I5 October by messenger. X (See minute inside)]

Remarks on theft of the late Friedrich III's cypher book

Most of the German newspapers have this morning reproduced a paragraph from the semi official "Berliner Politische Nachrichten" ${ }_{218}$ to the effect that "a Cypherbook formerly given to the late Emperor Frederick for secret communications with the higher Officers of State, and which His Majesty had by him even on his deathbed, has been lost and has vanished leaving no trace behind."

The paragraph concludes by asking whether the Chief of the secret Police $^{219}$ has only just learned of this, and, remarks that the whole affair is "exceedingly strange".

I mention this matter only because about a month ago I heard from an indubitably trustworthy source of the loss of these cyphers and was informed in addition that (as has been usual of late when any documents of importance have been lost, stolen, or published contrary to the inclination of the Chancellor) Her Majesty The Empress Frederick ${ }^{200}$ has been accused of the theft and that the insinuation was added that the cypher had no doubt been given to England. ${ }^{221}$

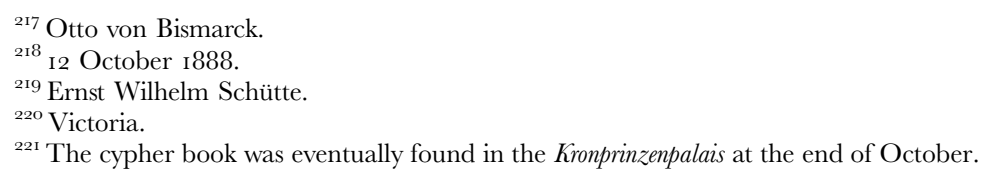




\section{FO 64/II89: William N. Beauclerk to Marquess of Salisbury, Confidential, No 317, Berlin, 15 October 1888}

[Received 22 October by messenger. For: The Queen; S[alisbury]]

Morell Mackenzie's book published in Germany and promptly confiscated in Berlin; imprisonment of Dr Geffcken

A German Edition of Sir Morell Mackenzie's book ${ }^{222}$ was published this morning at Styrum and Leipsig. It is said that a truckload of some 25.000 copies arrived at Berlin early in the morning and the work was hawked about the streets for sale at the price of I mark 50 Pfennigs until noon when it was confiscated by the Police.

I should not trouble Your Lordship with noticing this matter, but for the fact that the reason of the seizure is stated to be that the publication of contradictions of official statements amounts in Germany to the crime of High Treason, and Sir Morell Mackenzie's refutation of the official report of the German Physicians ${ }^{223}$ is held to come under this category. The above event in connection with the arrest of Doctor Geffcken, ${ }^{224}$ under a similar capital charge, has caused some slight consternation in Berlin; for the citizens are commencing, as I am informed, to fear lest their most well meant and innocent actions may not bring down upon them the wrath of judgment of the supreme Authorities.

I have the honour to inclose a copy of the confiscated volume.

$[\ldots]$

P.S. Since writing the above I learn that I 30.000 copies of Sir Morell Mackenzie's pamphlet have been printed in this country, in German, and that the Editor ${ }^{225}$ has already appealed to the Courts of Law against the confiscation. According to German Law the prosecution for an offence of this nature must commence within a fortnight, otherwise the case falls to the ground, and in the instance of Doctor Geffcken judicial proceedings have already begun by his examination before the Juge d'Instruction ${ }^{226}$ at the Moabit prison in Berlin.

${ }^{222}$ The Fatal Illness of Frederick the Noble (I888); the German edition (enclosure to dispatch) was published as Friedrich der Edle und seine Ärzte (I888). It was confiscated following an order of the court at Mühlheim of I4 October I888.

${ }^{223}$ The official report was published in July I888 as Die Krankheit Kaiser Friedrichs III.

${ }^{224}$ Geffcken was arrested on 29 September 1888 and prosecuted for high treason because he had published extracts of Friedrich III's diary written during the Franco-Prussian War.

${ }^{225}$ Adolf Spaarmann.

${ }^{226}$ French: 'investigating magistrate'. Here, Georg Hirschfeld. 


\section{FO 64/II89: William N. Beauclerk to Marquess of Salisbury, Confidential, No 323, Berlin, 19 October 1888}

[Received 22 October by messenger. Qy: The Queen / Prince of Wales; S[alisbury]]

Press article on late Friedrich III's political views potentially intended to encourage present emperor to desist from excessive opinions

With reference to my despatch No: 319 Confidential of yesterday's date, on the subject of the Political views of The late Emperor Frederick, and the article published in the "North German Gazette" thereupon, I have the honour to mention that there is another light in which the meaning of the said Article may be viewed. ${ }^{227}$

The political elections to the Reichstag and Landtag are coming on in a few days and are expected to be unfavourable to the Government, ${ }^{228}$ who have wished in the publication of the Article in question to show indirectly that the reigning Emperor can no longer, as such, entertain or put in practice the ultra Conservative opinions which he is supposed to have held as Prince William of Prussia and Crown Prince of Germany.

Such opinions are believed to have included a great enmity to the Jewish race as well as to the Roman Catholic population, very important elements in the German Nation, and considerable factors in political affairs in this country.

It is to prove this proposition that the theory is so strongly put forward that The Late Emperor could not - had his reign been prolonged - have maintained or given further development to the very liberal views which are known to have animated His Majesty.

It is argued in this connection that the whole history of the Royal House of Brandenburg tends to prove that all excessive opinions held by the occupant of the Throne must, in practice, be modified to suit the traditions of the Nation and the exigencies of the time.

\footnotetext{
${ }^{227}$ The article disputed that Friedrich's disagreements with the policies of Wilhelm I when he was crown prince had any political implications. It was published in the Nordddeutsche Allgemeine Zeitung on I5 $_{5}$ October 1888.

${ }^{228}$ By-elections took place in three electoral districts before the re-opening of the Reichstag on 22 November; elections for the Prussian house of deputies were held on 30 October 1888.
} 


\section{FO 64/1211: Edward B. Malet to Marquess of Salisbury, Confidential, No 4, Berlin, 5 January 1889}

[Received 7 January by bag. For: The Queen / Prince of Wales; Qy: approve language; not to St Petersburg; S[alisbury]; Draft Sir E. Malet, Io January]

Conversation with Count Bismarck about Kölnische Zeitung's publication of his correspondence with Robert Morier concerning the latter's alleged warning to Colonel Bazaine during Franco-Prussian War

I have the honour to inform Your Lordship that Count Bismarck spoke to me today about the publication which has taken place in the newspapers of the correspondence between himself and Sir Robert Morier on the subject of the charges brought against the latter by the "Cologne Gazette". ${ }^{229}$ He said that he considered that he had just reason to complain of Sir Robert's transmitting the correspondence to the Press without going through the usual form of inquiring whether he, Count Bismarck, consented. If Sir Robert had made this inquiry, Count Bismarck would certainly have raised no objection to the publication. He had been greatly surprised at the tone of Sir Robert Morier's first letter, which in his opinion was rather that of a chief to a subordinate that that of one gentleman to another. Sir Robert made use of a phrase in it which showed that he misapprehended the bearing of the case. He seemed to think that he was charged with betrayal towards the Emperor Frederick and his Army. In the first place the Emperor Frederick was far away at the time of the alleged revelation to Marshall Bazaine and in the second place the charge against Sir Robert Morier was founded on the report of Major Deines ${ }^{230}$ which did not preclude the explanation that the intelligence, if originally given by Sir Robert, might have reached Bazaine without Sir Robert's complicity.

I said to Count Bismarck that I regretted most sincerely the publicity which had been given to the allegations against Sir Robert Morier by the Cologne Gazette because it was impossible to suppose for an instant that Sir Robert had done what was insinuated and because the attack was calculated to cause an acrimonious polemic

\footnotetext{
${ }^{229}$ On I6 December 1888 the Kölnische Zeitung accused Robert Morier of having betrayed Prussian military movements to Marshal Bazaine in August 1870. In his letter to Herbert von Bismarck of ig December i888, Morier demanded a public refutation. Bismarck, on 24 December, answered in the negative, whereupon Morier, on 3I December, declared his intention of publishing the correspondence. It was published in The Times and the Daily Telegraph on 4 January i889.

${ }^{230}$ Report of 2 April I886. The report had been privately communicated to Morier by Herbert von Bismarck in March I888.
} 
between the Press of the two Countries which might have an evil influence on the friendly feelings between them.

Count Bismarck urged that it was owing to Sir Robert Morier that the matter had got into the papers. He said that Sir Robert had written on the subject to Herr Hinzpeter, formerly tutor to the Emperor inclosing copies of the correspondence between him and Marshall Bazaine, ${ }^{231}$ that Herr Hinzpeter had forwarded Sir Robert's letter to the Emperor, that in reply Herr Hinzpeter had been furnished with Major Deines' reports ${ }^{232}$ - that Herr Hinzpeter lived at Bielefeld, which was close to Cologne, that very likely he had talked about the affair and that so the Editor ${ }^{233}$ of the Cologne Gazette had come to hear it and had then revealed what he knew imperfectly to the Public.

It was a mistake, he said, to consider that what appeared in the Cologne Gazette necessarily emanated from the Government. It was the most influential paper in that part of Germany and the Government occasionally gave it intelligence. In the present instance when Sir Robert Morier's denial appeared, ${ }^{234}$ the Editor certainly claimed the help of the Government in substantiating the statements already made and had urged that unless it was given, the character of the paper for trustworthiness would be lost. Upon this he had been furnished with the reports made by Major Deines. Count Bismarck then proceeded to comment on the article in the Times of the $4^{\text {th }}$ instant: and said that he was surprised that so serious a newspaper should not think it below its dignity to found a charge against Prince Bismarck in connection with the matter which was in fact untenable and to read him a lecture on the manner of treating foreign officials, when Prince Bismarck had done nothing in this case which could justify such an attack. The only document relating to the matter which had emanated from a member of the Government was his (Count Bismarck's) letter to Sir Robert. The Times styled it "crude". Count Bismarck thought that considering the tone of the letter to which it was an answer, it was remarkable for its moderation.

\footnotetext{
${ }^{23 \mathrm{I}}$ Copies of Morier's letters of 25 July and 28 August I888 (the latter containing Bazaine's denial) were sent to Hinzpeter on 5 October.

${ }^{232}$ Reports of 2 April I886 and I2 November I888; they were published by the Kölnische Zeitung on 2 January I889.

${ }^{233}$ August Schmits.

${ }^{234}$ The Times, 2I December I888.
} 


\section{FO 64/121 I: Edward B. Malet to Marquess of Salisbury, Secret, No 5I, Berlin, 3 February 1889}

[Received 6 February. Qy: The Queen / Washington (secret) / Admiralty (secret); S [alisbury]; Paris; P.L. [printed letter], I6 February; L[ister]]

Report of a German shipbuilder receiving an American order for warships; Count Bismarck on need for England to strengthen her fleet and a united front between England and Germany

Count Bismarck ${ }^{235}$ told me yesterday very confidentially that he had received a report from Count Münster, the German Ambassador at Paris, to the effect that an agent ${ }^{236}$ of the ship building firm of Schichau at Elbing had been to him and told him that the United States Government had proposed to his firm to build for the Government six torpedo boats at once, and had made inquiries as to the time which his firm would take to furnish the Government with cruisers and men of war. Mess ${ }^{\text {rs }}$ Schichau had refused the order for reasons which Count Bismarck did not state to me, but His Excellency said that he was anxious that Your Lordship should know of the circumstances which he said, to his mind, pointed more than ever to the necessity of England strengthening her fleet, and the utility of its being thoroughly understood in the United States that the Governments of England and Germany were in complete understanding, and that there was no chance of dividing them upon questions where the interests of the United States were antagonistic to one or the other.

He said that politics in the United States were always dominated by electioneering considerations, and that the vote of English and German naturalized Americans were weighty factors. These factors would be united if the policy of Germany and England were united, and such an union would exercise a wholesome influence over the executive, and compel it to moderate its aggressive tone.

\section{FO 64/1212: Edward B. Malet to Marquess of Salisbury, No Io6, Berlin, 22 March 1889}

[Received 25 March by bag. Qy: Express satisfaction, 30 March; Copy to: War Office, P.L. [printed letter], I April; S[alisbury]]

Expression of regret at the departure of Colonel Swaine as military attaché to Berlin; qualities required of someone in this position

While I was absent from my post Colonel Swaine C.B, who has been military Attaché at this Embassy since 1882, with an interval of

\footnotetext{
${ }^{235}$ Herbert von Bismarck.

${ }^{236}$ Name not traceable.
} 
service in Egypt, ${ }^{237}$ quitted Berlin on being appointed to the command of the $2^{\text {nd }}$ Battalion of The Rifle Brigade. I desire to take the earliest opportunity on my resuming my post to record my high sense of the manner in which Colonel Swaine has discharged the duties of his office during the period which he has served under me.

The performance of these duties at Berlin require[s] great tact and circumspection on account of the suspicious eye with which all inquiries are regarded, and Colonel Swaine succeeded in completely winning the confidence of those with whom he came in contact by his straight forwardness, his soldierlike qualities, and his ability. $\mathrm{He}$ was regarded with friendship by The Emperor Frederick and the present Emperor, and was always treated with exceptional courtesy by the military authorities. He was in every way the model of what a military attaché should be, and I sincerely regret that the withdrawal of his services from Her Majesty's Embassy should have become unavoidable.

\section{FO 64/1213: William N. Beauclerk to Marquess of Salisbury, No 231, Berlin, 17 August 1889}

[Received I9 August by messenger. For: The Queen / Girculate; S[alisbury]]

Banquet to celebrate Her Majesty's appointment as honorary colonel of Queen Victoria's Regiment; celebration of Anglo-German solidarity

I beg to report to Your Lordship that I had the honour yesterday of attending the Banquet of "Queen Victoria's Regiment", the $I^{\text {st }}$ Dragoon Guards, on the occasion of Her Majesty the Queen having accepted the honorary Colonelcy of the Regiment. ${ }^{238}$

The Adjutant, Count G[.] Waldersee, had called at the Embassy about ten days ago and, on behalf of the Colonel ${ }^{239}$ and Officers, invited our entire staff to be present at the banquet.

The invitation was originally for dinner at 6 P.M., but at the command of His Imperial Majesty the Emperor, who specially desired to be present, the arrangements were altered to suit His Majesty's engagements, and a luncheon was given at I P.M.

${ }^{237}$ Swaine was military secretary of the expeditionary force to Egypt in I882.

${ }^{23^{8}}$ The honorary colonelcy was conferred on Victoria on 2 August I889 on the occasion of Wilhelm II's visit to England.

${ }^{239}$ Oberleutnant von Kotze. 
The entertainment happened to coincide with the annual regimental festival commemorating the battle of "Mars la Tour", ${ }^{20}$ where the Corps so highly distinguished itself, at great sacrifice of life, in coming to the rescue of two Regiments of Infantry which were sorely pressed by the enemy.

The banquet was thronged with Royal and distinguished guests.

On his arrival, the Emperor was received by a deputation of veterans of the Regiment, survivors of the campaign in which it has taken part.

His Royal Highness Prince Albrecht of Prussia, Regent of Brunswick, proposed the health of Her Majesty the Queen, as the new Chief of the Regiment, in a terse and appropriate speech. The health of Her Majesty was received with the utmost enthusiasm, the Emperor and all present cheering vociferously and standing whilst the band played "God save the Queen".

The Colonel of the Regiment next gave the health of the Emperor, as head of the German Army. He said that the motto of the Regiment in peace and in war, was "Long live the King": - he trusted that they might in any future campaign shout "Victoria" in every sense.

His Majesty the Emperor responded in a feeling speech, lauding the brotherly sentiments which had always existed amongst the troops of the Empire, and which even more than their devotion to the throne had led them to perform the valorous feats of which they were so justly proud.

I then had the honour to address the company present in the following words:

"Your Imperial Majesty and Gentlemen! My Colleagues of the British Embassy and I myself will never forget the honour which we have had today, in attending this banquet commemorating an incident which may well be regarded as pregnant with importance in the History of our own times."

Germany and England united by the most ancient bonds of race and kindred, have marched together in unbroken alliance from the earliest period of their national existence. By land and by sea they proceed hand in hand with the common object of preserving international Peace and furthering the progress of civilization in every quarter of the Globe.

The close ties of family relationship between the Imperial Houses have today been accentuated by the honorary distinctions exchanged between Our Sovereigns.

\footnotetext{
${ }^{240}$ Battle of Mars-La-Tour of 16 August I87o.
} 
Gentlemen I esteem it a high privilege to be permitted to thank you in the name of my great and gracious Queen for the cordial manner in which you have welcomed Her as your chief, and for giving to us the opportunity of making the personal acquaintance of the officers of "Queen Victoria's Regiment."["]

Colonel Russell also expressed the honour and pleasure felt by the British army in being more closely connected with the Imperial forces by the event celebrated on this occasion.

The whole proceedings were marked by excessive courtesy and cordiality towards ourselves on the part of His Imperial Majesty the Emperor and all the donors of the entertainment.

His Royal Highness Prince Albrecht was good enough personally to compliment me most graciously on my small oration, and I venture to say that the occurrences of the day may be regarded as having given a distinct and marked proof of friendship, unison and alliance between Great Britain and the German Empire.

\section{FO 64/1214: Edward B. Malet to Marquess of Salisbury, No 269 , Berlin, 4 October 1889}

[Received 7 October by messenger. For: The Queen; S[alisbury]]

\section{Emperor has officially repudiated claims that he shares the viewes of the Junker party}

I have the honour to inclose herewith copy and translation of an arti$\mathrm{cle}^{241}$ which has appeared in the Official Gazette stating that the Emperor disapproves of the views expressed by the "Kreuz Zeitung" in a certain article ${ }^{242}$ which it mentions and that His Majesty does not permit any party to indulge in the pretence of possessing The Imperial ear.

The appearance of this statement in the official Gazette has caused much sensation among German politicians.

Ever since the accession of the present Emperor the old conservative formerly styled "Junker" party have striven not only to draw His Majesty within their fold but to cause it to be believed that the Imperial views are already in consonance with theirs.

Their organ the "Kreuz Zeitung", has recently in a series of articles put forward this pretension with so much arrogance that The Emperor has deemed it necessary to disclaim such partizanship

\footnotetext{
${ }^{241}$ Enclosures: untitled extract, Deutscher Reichsanzeiger und Königlich Preußischer Staatsanzeiger, 2 October 1889 and translation, 4 October I889.

${ }^{242}$ On 26 September 1889 .
} 
officially less by repeated reiteration it should gain credence among the masses. The step has given great satisfaction to the moderates who form the cartel party ${ }^{243}$ and are the section of the Reichstag upon which the Government rests for support.

There is no doubt that the Emperor and Prince Bismarck deemed such a public utterance to be necessary in order to retain the support of this party and there is equally no doubt that its appearance has had tranquilizing effect upon all Germany, as the supposition that The Emperor was impregnated with the antiquated and arrogant views of the old feudal party might have a serious effect on the conduct of the moderates in the coming session of the Reichstag and on the next elections.

\section{FO 64/1214: Edward B. Malet to Marquess of Salisbury, Secret, No 282, Berlin, 13 October 1889}

[Received i6 October. For: The Queen; Secret to: St Petersburg / Vienna / Constantinople; S[alisbury]]

Czar's visit to Berlin; reassured by Bismarck of Germany's peaceful aims towards Russia; England dismissed as unable to form an alliance against Russia due to complex parliamentary institutions

I had this evening an opportunity of speaking to the Emperor about the visit of His Imperial Majesty the Czar who left for Schwerin at four o'clock in the afternoon. ${ }^{244}$

His Majesty said to me that the visit had done great good, that the Czar came to Berlin with much misgiving, as, however strange it might seem, he really harboured the idea that Germany intended to make war upon Russia.

He had, however, had an interview of an hour and a quarter with Prince Bismarck, ${ }^{245}$ who had gone over the whole political situation with him, and had really succeeded in dispelling the strange cloud of anxiety which seemed to oppress His Majesty. He had assured the Cizar that Germany desired nothing but peace, and had quieted his mind respecting the existence of hostile alliances. The Emperor said to me that the Czar came back from the interview a changed man and had afterwards been quite cheerful and pleasant, and had invited Him to the military manoeuvres next summer in Russia, an invitation which His Majesty had at once accepted.

\footnotetext{
${ }^{243}$ Malet is referring to the National Liberals and the Free Conservatives; originally the Deutschkonservative Partei was part of the 'Cartel' party. See n. 208 in this section.

${ }^{244}$ Alexander III visited Berlin from II to I3 October I889.

${ }^{245}$ On II October.
} 
Immediately afterwards I spoke to Count Bismarck ${ }^{246}$ on the same subject telling him what the Emperor had said, and His Excellency entirely confirmed it. He said that in conversation with his father the Czar had shown particular apprehension on two points, an alliance concluded with England, and alliance projected with Turkey, both of an offensive nature towards Russia.

Prince Bismarck had reassured him on both points. He had said that, although there was an excellent understanding with Her Majesty's Government, and that the general lines of policy between the two Governments was similar, that these only tended towards the preservation of peace, they had no aggressive nature, and that, although Your Lordship was the strongest Prime Minister that The Queen had had for twenty years, the traditions and the complex nature of the British Parliamentary institutions made it impossible for you to conclude an alliance of the kind which His Majesty seemed to apprehend.

With regard to Turkey, Prince Bismarck had said that the visit of the Emperor of Germany to Constantinople ${ }^{247}$ was only prompted by a love of travel and that the timid and vacillating character of the Sultan $^{248}$ rendered it impossible to entertain the idea of contracting serious engagements with him; at the same time Prince Bismarck assured the Czar that no design of this kind formed part of the programme of the Emperor of Germany's intended journey.

\section{FO 64/1234: Edward B. Malet to Marquess of Salisbury, Confidential, No 36, Berlin, 8 February 1890}

[Received io February. For: The Queen / Prince of Wales / Circulate; S[alisbury]

Emperor suggests international conference on Labour Question; Bismarck unwilling to adopt more liberal stance; reflections on relationship between Bismarck and emperor

The Emperor's letters to the Chancellor and the Ministers of Trade and Public works giving instructions that invitations should be issued to certain Foreign Powers to join in a conference on the labour question continue to be the absorbing topic of the moment. ${ }^{249}$

\footnotetext{
${ }^{246}$ Herbert von Bismarck.

${ }^{247}$ Wilhelm II left Potsdam for Athens and Constantinople on 18 October and returned on $5_{5}$ November.

${ }^{248}$ Abdul Hamid II.

${ }^{249}$ The rescript addressed to Bismarck demanded the convocation of an European conference on social reform; the second proclamation of 4 February instructed ministers Berlepsch and Maybach to prepare legislation on social insurance, the regulation of working hours and conditions, and the representation of labour.
} 
The public tendency is to believe that the Emperor and the Chancellor are not agreed as to the wisdom of the step which His Majesty has taken and I fancy that there is no doubt that this view is correct.

Five years ago Prince Bismarck spoke to me generally on the subject of liberal legislation with a view to courting popularity. It was at a time when there was grave apprehension that the Emperor William's end was near and it was supposed that the accession of the Emperor Frederick would inaugurate an era of liberal reforms. The Chancellor then said to me alluding to the repressive and autocratic Government of which he was the administrator that it might be an antiquated system not fitted to modern ideas, but that he was too old to try a new one and that he should retire into private life rather than endeavour to adapt himself to the new state of things.

I believe that the Chancellors views have not changed and that he only remains in office at the earnest request of the Emperor and on condition that he should have nothing to do with the working of the Emperor's project.

To insure this he has resigned ${ }^{250}$ the Portfolio of the Ministry of commerce and he has disengaged his responsibility by refusing to countersign the Royal Rescript.

It might be expected that so decided a difference of opinion between the Sovereign and his first Minister would lead to the latter's retirement, but it must be remembered that the Emperor must have paramount reasons for wishing to retain his services and that they are of a nature to carry most serious weight with the Chancellor also.

In the first place he is the creator of the Empire and the Captain of the Ship, his disappearance from the helm would be a matter of most serious importance affecting not only internal affairs, but in a far graver manner the external relations of the Empire.

It is every where felt that Prince Bismarck is a guarantee of peace. He seeks no more victories. His only aim is to consolidate what he has made. No such feeling prevails with regard to the young Emperor. On the contrary even in Germany it is thought that ambition in every direction is latent in his character and that if it does not find vent in a peaceful direction it would do so in another and more dangerous one.

The Emperor is well informed as to the opinions which have been formed of him and he knows that public confidence would be shaken if Prince Bismarck were to cease to be at his side. 
These considerations probably operate strongly on the Chancellor. He feels that it would not only be unchivalrous to abandon the young Emperor but that it might also be unsafe.

On the other hand his displeasure at the Emperor's liberal effort may be tempered by the conviction that it will ultimately prove abortive, while in the meantime it may again gain votes in the approaching election for the Reichstag. ${ }^{25}$

Some go so far as to consider that the whole matter is an electioneering manoeuvre; but I believe that the Emperor is perfectly sincere and that he thinks it is his duty and his interest to grapple with the great problem of the age.

\section{FO 64/1234: Edward B. Malet to Marquess of Salisbury, Confidential, No 7o, Berlin, 22 March 1890}

[Received 24 March by messenger. For: The Queen / Circulate / Confidential to Embassies; S[alisbury]]

\section{Bismarck's enforced resignation and its effects}

Although in the letter from The Emperor accepting Prince Bismarcks resignation His Majesty speaks of the uselessness of attempting to induce him to withdraw it, it is an open secret that The Chancellor finally resigned at His Majestys reiterated request. ${ }^{252}$

The Prince first announced his intention of resigning when The Emperor decided to invite the labour Conference. ${ }^{253}$ He then proposed however to remain as Chancellor and only give up the office of Prussian Prime Minister. He subsequently decided that this was not a workable scheme and he determined to retire altogether but he certainly intended to await the meeting of the Reichstag, after Easter and to attend its first debates.

I believe however that the prospect of retirement exercised an injurious effect upon his nervous system and that the Doctors were of opinion that to prevent a serious illness it was advisable that he should give up all work as soon as possible. The Emperor acted upon this advice and requested the Chancellor ${ }^{254}$ to send in at once the resignation which he intended for a later period.

\footnotetext{
${ }^{25}$ Elections for the Reichstag were to be held on 20 February I89o.

${ }^{252}$ Bismarck handed in his letter of resignation on 18 March I888. It was accepted by Wilhelm II on 20 March.

${ }^{253}$ See preceding dispatch.

${ }^{254}$ On I7 March I890 (medical reasons were irrelevant).
} 
But patients are not always of the same opinion as the medical advisors and Prince Bismarck absolutely denies that the state of his health precluded him from discharging the duties of his office.

Hence unfortunately his final retirement has been accompanied by a good deal which his conspicuous services and great position made it desirable to avoid.

Count Bismarck has also resigned ${ }^{255}$ but the Emperor has as yet refused to accept his resignation. I believe that His Excellency will maintain it and that the Emperor will be obliged to give way.

All the other Ministers remain but it is doubted whether the cabinet thus composed will long hold together. The new Chancellor, General Caprivi, is a strong conservative while Herr v. Botticher [sic] his principal Minister has well marked liberal tendencies which were only held in control by the powerful will of Prince Bismarck.

\section{FO 64/1234: Edward B. Malet to Marquess of Salisbury, Confidential, No 74, Berlin, 27 March 1890}

[Received 3I March by messenger. For: The Queen; S[alisbury]]

Resignation of Count Bismarck; diplomatic corps wish to see Bismarck take leave of Berlin without offending the emperor

As I foreshadowed in my Despatch $\mathrm{N}^{\mathrm{o}} 70$ of the $22^{\text {nd }}$ instant, The Emperor has not been able to prevail upon Count Bismarck to remain in office and the post of Minister for Foreign Affairs has been offered by His Majesty to Count Alvensleben, German Minister at Brussels, who, however, is very unwilling to accept it. ${ }^{25}$

A story has appeared in the papers to the effect that a heated discussion took place at Her Majesty's Embassy between The Emperor and Count Bismarck after the dinner which I had the honour of offering $^{257}$ to Their Majesties and the Prince of Wales and that the discussion ended in The Emperors abruptly accepting His Excellency's resignation. ${ }^{25^{8}}$

\footnotetext{
${ }^{255}$ Herbert von Bismarck offered his resignation on 2I March; he was dismissed on 26 March.

${ }^{25}{ }^{6}$ On 22 March Herbert von Bismarck suggested Alvensleben to be his successor but the latter declined, ultimately due to his lack of parliamentary and oratory skills. See also previous note.

${ }^{257}$ On 24 March I8go.

${ }^{258}$ Edward visited Berlin from 2I to 28 March i889, then proceeded to Coburg. The dinner at the British embassy took place on 24 March.
} 
There is absolutely no foundation in this report. I can affirm from personal information and observation that the Emperor's communications with Count Bismarck on this subject have been characterised by perfect self restraint on both sides and that His Majesty sought by kindness of manner and delicate persuasion to induce him to relinquish his determination to resign.

Count Bismarck assures me that his health obliges him to seek repose and that The Emperor's offer to allow him to go on leave for six months is impracticable because it would prevent the absolute rest of which he has need.

The Ambassadors were anxious to ascertain whether it would be displeasing to The Emperor if they were to go to the Station when Prince Bismarck leaves ${ }^{25}$ in order to bid him farewell and they deputed me to sound His Majesty on the subject. I therefore asked His Majesty whether he would mind my seeing the Prince off and I said that I asked, because, if I went to the station there was no doubt that my colleagues would do the same and that we were anxious lest such a step might be looked upon as a demonstration and so in some degree annoy His Majesty. The Emperor replied that he had not the slightest objection and that I might take my whole staff with me if I liked and he further authorised me to tell the other Ambassadors the answer which He had made to me so that they might have no hesitation on the subject.

\section{FO 64/1235: Edward B. Malet to Marquess of Salisbury, No roo, Berlin, 3 May 1890}

[Received 5 May by bag. For: The Queen / Prince of Wales / Mr Matthews / Commercial Department to see; S[alisbury]]

Report on the quiet nature of socialist demonstrations on May Day

I have the honour to report that no disturbances took place in Berlin on the first Instant in connexion with the Socialistic movement, that work was carried on in most of the manufactories and workshops and that the number of men who absented themselves on that day was small.

Special precautions had been taken by the police to endure the maintenance of order in the quarters of the town inhabited by workmen; but it is stated that no special orders were given to the troops and that the usual exercising took place on the Tempelhof Fields.

\footnotetext{
${ }^{259}$ Bismarck left Berlin for Friedrichsruh on 29 March i89o.
} 
Some difference, however, was noticed in the workman's [sic] trains arriving in Berlin in the morning which were strikingly empty, and during the day small bands of workmen were seen proceeding to places of amusement in the suburbs. In general, however, the meetings announced to take place at various beer-gardens on the morning of the $\mathrm{I}^{\text {st }}$ were very poorly attended.

One or two attempts were made to nail red flags to the telegraph and telephone posts during the night, but these were taken down at dawn by the police.

Over 200 manufactories and workshops granted a holiday to their men voluntarily, but the total number of men employed by these does not appear.

At the Central Office of the Association of Berlin Iron foundries, Engineering works and allied Industries it was announced that, in 48 establishments with a total number of I0,769 men, only 2,034 or about one fifth had not appeared at work.

The accounts which have come in from other parts of Germany are much of the same nature. A certain number of men appear to have abstained from work, but no riots are reported.

\section{FO 64/1235: Edward B. Malet to Marquess of Salisbury, No I 6, Berlin, 24 May 1890}

[Received 20 May by bag. For: The Queen / Prince of Wales / Circulate; Qy: Copies to Embassies, bag 28 May; (Interesting); S[alisbury]]

Interview with General Caprivi à propos Bismarck's problematic statements and foreign press reports about them; assurances of good relations with England

General Caprivi asked me to come to see him today at three o'clock, and, on my presenting myself, His Excellency said that he desired to speak to me regarding the recent utterances of Prince Bismarck as recorded in the press of different countries. ${ }^{260}$ I was aware, he said, of the great respect and regard which he entertains for Prince Bismarck, but it really looked as if the moment had come, when he must distinguish between the Prince Bismarck of the past and the Prince Bismarck of the present.

He could not regard Prince Bismarck's recent remarks to correspondents as wise, justifiable or even true and he confessed that they caused him much pain and even anxiety, lest they might prejudice the confidence which he hoped that foreign Governments

\footnotetext{
${ }^{260}$ Caprivi was referring to Bismarck's interviews published in the Russian Novoye Vremya (ıо May I89o) and French Le Matin (I8 May I89o). See n. 316 in Dresden section.
} 
would repose in the policy of the Emperor and of His Majesty's Government. As long as Prince Bismarck confined himself to talking about German Affairs and his own retirement, no great harm could be done; but when he began to speak about the policy of Germany towards other countries and to hint at the view that the moment had come for Germany to rally to Russia, it was time to speak out plainly and for the Imperial Government to dissociate itself from all complicity in the utterance which came from Friedrichruh $[$ sic $]$.

The Government was unfortunately unable to take any public step in this direction, a contradiction in the newspapers would only awaken fresh controversy. It might become a question whether, if the evil became more serious, the clause of which Prince Bismarck was himself the author and which had been inserted in the penal Code to meet the case of Count Arnim, ${ }^{261}$ should not be invoked against the Prince himself; that was, however, for future consideration.

In the meantime the Emperor had desired him to say to me that there was not the remotest foundation for the insinuation which Foreign newspapers had based upon the disclosures of the Prince, to the effect that the existing alliances ${ }^{262}$ were considered to have run their day and that Germany proposed now to draw more closely to Russia.

General Caprivi went on to say that Prince Bismarck had talked to him about Foreign Policy, ${ }^{263}$ and had said that he (the Prince) had been like a juggler throwing balls from one hand to another and ringing the changes upon them. General Caprivi had replied that that might be possible for the Prince; but that if he himself were to attempt it, he should merely let the balls fall and be regarded as incompetent. He only knew of one policy and that was the one which he had announced on assuming office, ${ }^{264}$ and which was to continue the situation to the best of his ability as he found it; and General Caprivi finished by saying that the Emperor and he both held especially to being on the best terms with England and that he had invited me to see him at the Emperors desire in order to dispel any doubts which might possibly have been engendered in Your

\footnotetext{
${ }^{26 \mathrm{I}}$ Article 335a, which prohibited the unauthorized disclosure of official documents, was introduced into the Imperial Criminal Code in I876. It was a reaction to the Arnim affair of 1874 in which the former ambassador to Paris was charged of illegally retaining diplomatic documents, and subsequently sentenced to nine months imprisonment.

${ }^{262}$ This is referring to the Triple Alliance (see n. I74 in this section).

${ }^{26}$ Most probably on 2I March; the day after Bismarck's dismissal.

${ }^{264}$ Caprivi was referring to his speech in the Prussian house of deputies of ${ }_{5} 5$ April I8go.
} 
Lordship's mind by the reports of the interviews which had occurred at Friedrichsruh.

\section{FO 64/1253: Power Henry Le Poer Trench to Marquess of Salisbury, No 25, Berlin, 7 February I89I}

[Received 9 February. For the Queen / Prince of Wales / Print (Western Europe) / Eastern Department; S[alisbury]]

Downfall of Crispi in Italy; concerns for Triple Alliance; Marschall hopes that King of Italy will not cut expenditure for military and navy forces due to financial crisis

The news of the fall of Signor Crispi's Cabinet was received in this capital with much surprise and the Leading Papers express regret at what they term the temporary defeat of a statesman who was not only friendly towards Germany but an ardent supporter of the Triple alliance. ${ }^{265}$

The "North German Gazette" ${ }_{266}$ attributes Signor Crispi's defeat to the position he took on the financial question, now the vital question, and says it now remains to be seen where the statesman is to be found capable of rehabilitating the finances of Italy.

In the opinion of "National Zeitung" ${ }^{\text {"267 }}$ Signor Crispi's downfall need cause no anxiety; he did not form the Triple Alliance, all he did was to carry on the policy of his predecessors, which the elections of last November show is approved by a very large majority of the electors. ${ }^{268}$ His disappearance for a while will in no way alter or endanger the Triple Alliance, but it is certain that the interests of Italy all point to the desirability of an early return to Power of such an eminent Statesman. Baron von Marschall told me, in the course of a conversation I had with him this morning, that the Imperial Government had heard of the fall of Signor Crispi with sincere regret and that, in his opinion, the King will have great difficulty in finding a statesman strong enough to form a Cabinet which will satisfy all parties, and considers Crispi's return to Power merely a question of Time. He attributes Crispi's defeat partly to his financial policy, which was his weak-point, but mainly to his want of tact and brusque manner in dealing with the Chamber, and also to his violent

\footnotetext{
${ }^{26}$ The Italian government, under Francesco Crispi, handed in its resignation after a parliamentary defeat over a financial bill on 31 January I89I. It was succeeded on 6 February. For the Triple Alliance see n. I74 in this section.

${ }^{266}$ Norddeutsche Allgemeine, 2 February I89I.

${ }^{267}$ On 4 February i89i.

${ }^{268}$ The elections of 23 and 30 November saw the victory of the ministerial party, the Sinistra Storica.
} 
language. The Triple Alliance he believes to be in no way imperilled, but fears that Signor Crispi's successor ${ }^{269}$ may seek a way out of the financial difficulties by asking the Chamber to consent to a considerable reduction in the expenditure for the Army and Navy. This Germany would greatly deprecate as weakening Italy's powers of defence and leaving her more open to an attack from France. Germany, Baron von Marschall added, is fully alive to Italy's present financial difficulties and would not go so far as to protest against such reductions. But from the tone of His Excellency's language I think it not impossible that were such a reduction proposed, the Imperial Government might, in a friendly way, counsel Italy to make economies in some other direction and advise her not to reduce her army and navy.

Baron Marschall, however, thinks and hopes that the King will resist any attempt to cut down the naval and military budgets and believes him to be as fully alive as Germany is to the importance of maintaining peace in Europe and that the best way to do this is not to invite attack by weakening the naval and military forces of Italy.

\section{FO 64/1253: Power Henry Le Poer Trench to Marquess of Salisbury, Secret, No 40, Berlin, 28 February 189I}

[Received 2 March. For: The Queen / Prince of Wales; S[alisbury]]

War of words between semi-official press and newspapers supporting Bismarck's criticisms of the emperor

Much excitement has been caused here of late by the war of recrimination which has been carried on between the semi-official German papers and those papers which are said to encourage and support Prince Bismarck in his constant attacks against, and severe criticisms of, the policy of the Imperial Government.

It is an open secret that the ex-Chancellor already controls the "Hamburger Nachrichten", and it is generally believed that he has also succeeded in winning over the "Münchener Allgemeine Zeitung". Many of the hostile articles which appear in these papers are supposed to be inspired, if not written, by the ex-Chancellor, who is said to be also organizing a party opposition to the Court and the Government.

It is asked: how long will The Emperor submit to these attempts of the ex-Chancellor to thwart him on all sides? Baron von Marschall,

\footnotetext{
${ }^{269}$ Antonio Starabba di Rudini.
} 
who spoke to me very confidentially on this subject last week, said that these constant endeavours to discredit The Emperor's policy were most galling to His Majesty. The ex-Chancellor was trading on his popularity and prestige; it was true that Germany owed much to him, but there were also limits to the forbearance of The Emperor and the country. The Emperor would be extremely loth to resort to severe measures, such as prosecuting the ex-Chancellor. The Government hoped therefore to be able to confine their action to refuting in the official and semi-official papers any statements of the ex-Chancellor seeking to resist or discredit The Emperor's policy, as well as all false reports that might be spread by his supporters.

I enclose copy and translation of an Article from the North German Allgemeine Zeitung contradicting a report supposed to have been circulated by Prince Bismarck's friends. ${ }^{270}$

At a dinner given the other day ${ }^{271}$ by General von Caprivi, The Emperor, who spoke on almost every subject, including even socialism, stated very clearly that should the social Democrats overstep the bounds of legality they will meet with the most decided repression. This was also considered as a warning to the ex-Chancellor. Again at the annual dinner given here by the members of the Provincial Diet of Brandenburg, ${ }^{272}$ His Majesty severely condemned the attempts that were being made to instil anxiety into the minds of the people and to foment a spirit of discontent, if not, of insubordination. These words were likewise considered as directed against the ex-Chancellor.

From the tenor of his remarks it was quite evident to me that Baron von Marschall is greatly incensed against the ex-Chancellor, and should the latter go so far as to lay himself open to a charge of high treason or carry out the intention imputed to him of publishing Documents which, though his own property, are of a very confidential nature, it would not surprise me if he were to meet the same fate that overtook Count Arnim. ${ }^{273}$

On the other hand Prince Bismarck expresses great indignation at being made responsible for all the political articles in the "Hamburger Nachrichten", though he does not say that they do not on the whole reflect his opinions. But he absolutely denies that

\footnotetext{
${ }^{270}$ The article disputed reports that the Prussian ministerial council (Ministerrat), on I5 February I89I, had deliberated on measures against Bismarck's press activities. Enclosures: untitled cutting and translation from Norddeutsche Allgemeine Zeitung of 20 February I89I.

${ }^{271}$ On 13 February i89i.

${ }^{272}$ On 20 February I89I.

${ }^{273}$ See n. $26 \mathrm{I}$ in this section.
} 
he is seeking to discredit the policy of The Emperor or is trying to throw difficulties in the way of the Government. What are imputed to him as attacks against The Emperor are merely words of warning which he considers he has a right to address to the people when he thinks the country is menaced by danger. As proof of his desire not to meddle in politics or to re-enter political life, his defenders instance his having refused the offer of a mandate for the Reichstag and his declining the pressing invitation of his supporters to take his seat in the Herrenhaus. ${ }^{274}$

It is difficult to arrive at the real truth, but there can be no doubt that a general feeling of uneasiness prevails throughout the country, and thinking men are of opinion that Germany has more to fear from internal dangers than from foreign enemies.

\section{FO 64/1253: Edward B. Malet to Marquess of Salisbury, Very Confidential, No 53, Berlin, 13 March 1891}

[Received i6 March. For: The Queen / Prince of Wales; S[alisbury]]

Summary of political events during Malet's absence from Berlin: Waldersee's retirement as chief of staff; Shuvalov's visit to Bismarck; empress dowager's unfortunate visit to Paris

The chief incidents of interest which have taken place during my absence $^{275}$ from Berlin are the retirement of Count Waldersee from his post of Chief of the Staff, the visit of Count Schouvaloff to Prince Bismarck and its supposed connexion with the latter's attitude towards the Government, and the visit of The Empress Frederick ${ }^{276}$ to Paris. It may be of interest to Your Lordship if I divest them of the entanglements which the numerous versions of newspaper reports have woven round them.

Count Waldersee, who succeeded Field Marshal Count Moltke as Chief of the Staff, owes his fall to somewhat the same cause as brought about the fall of Prince Bismarck. ${ }^{277} \mathrm{He}$ had been the military mentor of The Emperor for many years, and like Prince Bismarck he fancied that his personal influence with His Majesty was so great that he could do pretty much what he chose. He had

\footnotetext{
${ }^{274}$ Bismarck stood for the by-election in Kehdingen and Neuhaus (Province of Hanover) and was elected member of the Reichstag in April I89I. As with his seat in the Prussian upper house (of which he had been a member since 1849) he did not attend the sittings.

${ }^{275}$ From I6 January to io March I89I.

${ }^{276}$ Victoria.

${ }^{277}$ Waldersee tendered his resignation at the end of January; he was dismissed on 2 February I89I.
} 
indeed urged The Emperor to get rid of Prince Bismarck and there is little doubt that he aspired to the post of Chancellor himself. No sooner did The Emperor become aware of his aspirations to supreme influence than His Majesty began to cool towards him, and in the autumn he made a remark which was supposed to show the way the wind was blowing. His Majesty said "Count Waldersee is endeavouring to thrust himself between me and the Chancellor."

A dispute had arisen between General Caprivi and Count Waldersee in regard to the duties of Military Attachés abroad. General Waldersee claimed that they should address their reports direct to him without submitting them to their diplomatic chiefs, and he is said even to have proposed that the military attachés should take charge of the missions in the absence of their chiefs. The resolute refusal of the Chancellor to yield to these demands brought about the critical moment in which the victory of either involved the fall of the other. The Emperor stood by the Chancellor.

In the meantime General Leszcynski [sic], who commanded the $9^{\text {th }}$ Army Corps, had fallen into disgrace for receiving Prince Bismarck with high honour as he passed through Altona on his way from Varzin to Friedrichsruh, and he had been relieved of his command. ${ }^{278}$ This gave a vacancy which enabled The Emperor to confer a post upon General Waldersee involving no loss of rank or position.

I am inclined to dismiss without much attention a rumour that The Emperor could not forgive General Waldersee's criticism of His Majesty's management of the troops under His Command at the autumn manoeuvres, ${ }^{279}$ though many aver that that was the beginning of his loss of Imperial favour.

General Waldersee has borne his reverse with dignity and The Emperor has since taken pains to make it appear that his personal regard for him has not diminished

\section{.$/ /$.}

The visit of Count Schouvaloff to Friedrichsruh had been long projected, for the invitation had been made and accepted at the time of Prince Bismarck's retirement from Berlin at the end of last March and the Emperor has long been aware that it was likely to take place nor has His Majesty shown any displeasure at the Ambassador's intentions, who however felt that, as time went on, the matter became somewhat delicate owing to the Prince's general

\footnotetext{
${ }^{278}$ Leszczynski - who had invited Bismarck for dinner on 9 January - was dismissed on 2 February; he was succeeded by Waldersee on the same day.

${ }^{279}$ On I9 September I89o.
} 
attitude and to the articles in the "Hamburger Nachrichten" which were attributed to his inspiration. ${ }^{280} \mathrm{He}$ therefore found excuses to put off the visit, but towards the close of the year he was again pressed by the Prince to redeem his promise. He then mentioned the matter to Baron von Marschall, who said that a mere visit, considering the intimacy which had existed for years between the two, could not offer ground for objection or unfriendly comment. But no date was mentioned and when, on the $13^{\text {th }}$ of February, ${ }^{28}$ Count Schouvaloff did actually go to Friedrichsruh, it was without the Knowledge of the authorities. He merely spent a few hours there and he has assured a Colleague that the Prince did not touch upon politics of any kind during the whole time they were together.

Two days afterwards The Emperor called first on Madame Herbette and then went on to call on Countess Schouvaloff. His Majesty was at once admitted at the Russian Embassy but the Countess was not at home and Count Schouvaloff received His Majesty, who then heard for the first time from His Excellency himself of his visit to Friedrichsruh. There is therefore no truth in the report current at the time, that the Ambassador took a message from The Emperor to the Prince. Nor is there, as far as I can learn, any reason for supposing that His Majesty was particularly annoyed at the visit. Count Schouvaloff is a "persona" as "grata" as a Russian Ambassador can be at Berlin. He is a gentleman and a conservative of the old Russian party, without the fads and ambitions of the younger generation of his countrymen, and I imagine that The Emperor would much regret his removal from the post which he holds.

$$
. / 1 .
$$

The result of The Empress Frederick's visit to Paris has caused recriminations all round. ${ }^{282}$ It was undertaken with the consent and approval of The Emperor and his advisers. Monsieur Herbette, the French Ambassador, who has honestly striven, during his tenure of office, to ameliorate the relations between France and Germany, had achieved a real success in inducing several French Painters of eminence to promise to send pictures to the coming international Exhibition of Art at Berlin, ${ }^{283}$ and The Emperor, who undoubtedly

\footnotetext{
${ }^{280}$ See previous dispatch.

${ }^{281}$ The visit actually took place on I2 February I89i.

${ }^{282}$ Victoria visited Paris on her way to London from I8 to 27 February I89I.

${ }^{283}$ The international arts exhibition - celebrating the $5 \mathrm{o}^{\text {th }}$ jubilee of the Verein Berliner Künstler - was opened on I May under the patronage of Wilhelm II and Victoria.
} 
wishes for peace and desires that a cordial feeling should exist between all the European Powers, thought that the moment had come when he might evince this feeling especially in regard to France. I suspect that there is truth in the suspicion that if The Empress Frederick's visit to Paris had passed off successfully $\mathrm{He}$ would himself have endeavoured to go there not long afterwards. This is however now strenuously denied. Unfortunately one mistake followed upon another in carrying out the project which was undertaken with such laudable objects.

In the first place no warning was given to the French Government. They had no time either to prevent the visit to Paris or to prepare the Paris public for it. Secondly The Empress' veil of incognito was not maintained with sufficient reserve. If Ambassadors and Ministers were received, some step should have been taken in regard to the Chief of the State. This was only done when the error become clear and on the fourth day after The Empress' arrival. The overture was declined. In the interval the drive to Versailles through the Park of St. Cloud had given a handle to the "patriots". ${ }^{284}$ When The Empress left Berlin it was settled that the visit should last at most three days. Now that all is over, it is maintained by those who were responsible here that if this programme had been maintained success instead of failure would have been the result. In any case it is now clear that the experiment was a perilous one, for the bitterness of feeling caused here by the conduct of Monsieur Déroulède and his party and the disinclination or powerlessness of the French Government to keep it within bounds, ${ }^{285}$ was so strong that it was within an ace of leading to a rupture involving the recall of Monsieur Herbette and Count Münster and a state of tension between the two countries of which the ultimate result might have been most serious.

Count Münster indeed has I believe only been saved by the declaration of Moniseur Herbette that he would himself be compelled to resign if the Count were recalled.

\footnotetext{
${ }^{284}$ Victoria visited the ruins of the Château de Saint-Cloud and the Palace of Versailles on 24 February. This was seen as a provocation due to the symbolism associated with their role in the Franco-Prussian War, and the subsequent proclamation of Wilhelm I as German Emperor in I871.

${ }^{285}$ During Victoria's visit adherents of the Ligue des Patriotes decorated the Strasbourg statue at La Place de la Concorde with French flags and also placed a wreath on the monument of Henri Regnault, a painter who had fallen during the siege of Paris in January I87I. The wreath was removed by the government for bearing the initials of the banned Ligue (L.D.P.), but was subsequently replaced after Déroulède threatened to interpellate in the National Assembly.
} 
The Decree reimposing obstructive passport regulations on the Alsace-Lorraine frontier has been strongly criticized as an act of petulance involving grave inconvenience to people who had nothing to do with the events in Paris. ${ }^{286}$ Baron Marschall upholds it as a logical sequence of what has taken place. He says that they were originally imposed by Prince Bismarck as a demonstration on the part of Germany against Boulangeism. At that time the French Government was so weak that General Boulanger and his party were sweeping all before it. Diplomatic representations to the Government were worse than useless. The passport regulations were introduced to rouse the better thinking people in France from their apathy and to show them the consequences of their allowing themselves to be overridden by a reckless minority. It is believed by the German Authorities that the overthrow of Boulangeism ${ }^{287}$ was due to the measure in question as it opened the eyes of the French to the precipice before them. A precisely similar situation showed itself at the time of The Empress Frederick's visit. The noisy minority again cowed the Government and the restoration of the obnoxious Passport rules was the best way of recalling the people of France to their senses. It is already asserted to be a success, as the Patriotic league is being credited with the inconvenience caused and a deputation from Alsace to The Emperor is, today, to present a loyal address disclaiming all connexion with the party of revenge.

\section{FO 64/1254: Edward B. Malet to Marquess of Salisbury, No 155, Berlin, 22 August 1891}

[[No date] For: Board of Trade, 26 August / Commercial Department; S[alisbury]]

Effects of Russia's ban on rye exports to Germany; press campaign for abolition of corn laws versus government intention to maintain them; prospects for German harvests unclear

The Decree issued by the Russian Government ${ }^{288}$ prohibiting the export of Rye from Russia has been made a pretext by a large portion

\footnotetext{
${ }^{286}$ On 28 February I89I, the imperial ministry for Alsace-Lorraine decreed the strict implementation of the passport regime which had been introduced on 22 May I888 but subsequently relaxed. Amongst other things, the regulation imposed visa requirements on all French citizens who crossed the border to Alsace-Lorraine, but this was abrogated in September I89i.

${ }^{287}$ The Boulangist movement declined in 1889 after Boulanger, fearing arrest for conspiracy and treason, fled to Brussels and then London. He was tried in absentia for treason later that year.

${ }^{288}$ The imperial ukase prohibiting the export of rye, rye flour, and bran was issued on II August and came into effect on 27 August.
} 
of the German Press to get up an agitation for the abolition of the corn duties which in Germany are very high amounting to fifty marks per tonne (a German tonne equals nineteen hundredweights two quarters, twenty pounds ten ounces). [Note in margin: ' $\AA^{2}-$ IO - o. Cwt: I9; qts: 2; lbs: 20; oz: IO']

The subject was discussed by the Council of Ministers ${ }^{289}$ under the Presidency of the Imperial Chancellor and it was decided neither to abolish nor reduce the existing duties on Corn.

The Government consider that the amount of Rye imported from Russia, which is comparatively small, can be replaced by consignments from America or other large grain growing countries and they are also of opinion that, pending negotiations with Austria and Italy for the renewal of commercial Treaties ${ }^{290}$ it would be very inexpedient and impolitic to make any change in the existing laws.

The reports too, received by the Government from various parts of the country are not on the whole discouraging and show that the harvest of Rye and wheat, though not a very good one, is likely to be only very little below average.

The policy of the Government has been severely condemned by a large section of the Press, its figures as regards the prospects of the Harvest are disputed and the agitation instead of diminishing seems to be on the increase. The Government while still determined neither to abolish nor alter the corn duties has decided ${ }^{291}$ to lower the railway rates for the conveyance of grain and mill produce for distances of over two hundred Kilometers. The reduction in the rate will come into force on the $\mathrm{I}^{\text {st }}$ proximo and the Chancellor will urge the smaller German States to follow the example of Prussia in this respect.

The present agitation has naturally led to enormous speculation in Rye which has risen considerably but the prices quoted are merely nominal and fluctuate according as the "Bulls" or the "Bears" get control of the market. ${ }^{292}$ It is likewise impossible to arrive at anything approaching correct data in regard to Harvest prospects. If the figures of the "Reichsanzeiger" even ridiculed, are correct the Rye Harvest this year should amount to $6,256,136$ tonne[s] or nearly as much as in 1887 .

\footnotetext{
${ }^{289}$ Sitting of the Prussian state ministry (Staatsministerium) on I5 August I89I.

${ }^{290}$ The commercial treaties with Austria-Hungary and Italy were signed on 6 December and passed by the Reichstag on 18 December I89I.

${ }^{291}$ On ${ }_{5} 5$ August I89I.

${ }^{292} \mathrm{~A}$ bull market being a buoyant period when prices rise; a bear market being when prices fall and financial pessimism sets in.

${ }^{293}$ Deutscher Reichs-Anzeiger und Königlich Preußischer Staats-Anzeiger of I4 August I8gI.
} 
By the recently contracted commercial treaty with Austria the duty on cereals coming into Germany was reduced from 5 marks to $3^{1 / 2}$ marks and in return for this reduction Austria decreased the tariff on numerous articles of German export. ${ }^{294}$

If the German Government were to reduce the tariff on cereals generally the advantage gained by Austria in its commercial negotiations would be cancelled and the treaty would run the risk of not being accepted by the Austrian Parliament and the German Government feel that they would be exposed to a suspicion of bad faith. The duty is imposed from political as well as economic motives and the former weigh heavily in the consideration of the question the political object being to enable Germany to be self providing in cereal in the event of war.

\section{FO 64/1273: Edward B. Malet to Marquess of Salisbury, Secret, No 17, Berlin, 13 January 1892}

[Received I8 January. For: The Queen; S[alisbury]]

Wilhelm II receives new Archbishop of Posen; Kulturkampf consigned to history as emperor seeks reconciliation between Germany and papacy

I have the honour to inform Your Lordship that Monseigneur Stablewski, the new Archbishop of Posen, was received by the Emperor on the II $^{\text {th }}$ instant. His Majesty tells me that He has great hopes that this appointment may be fruitful of good results, and that He had spoken to the Archbishop at length, and had explained to him that the principal difficulty which he would have to encounter in his diocese would be the democratic tendencies of the lesser clergy.

He had remarked that the Pope ${ }^{295}$ was equally interested with Monarchs in combating this tendency, and he expressed his regret that His Holiness should sometimes coquette with republican and democratic ideas.

Monseigneur Stablewski had replied that this action on the part of the Pope was only for show; and that, at heart, His Holiness was entirely conservative.

The Emperor went on to say that he was on the best of terms with the Pope: He had let it be known that the "Culturkampf" was for

\footnotetext{
${ }^{294}$ The reduction in tariffs was agreed during the negotiations for the new commercial treaty in March and April I89I at Vienna. The draft treaty to which Malet is referring to was concluded on 3 May; the final treaty was signed on 6 December I89I.

${ }^{295}$ Leo XIII.
} 
Him a matter of history only; and that His desire was, to enter on a path of conciliation in all matters in discussion between the Papacy and Germany. The Pope had received these overtures in a very friendly spirit, and His Majesty thought that the nomination of Monseigneur Stablewski, who was a man of high education and good family, would not only be agreeable to the Pope, but would prove His Majesty's solicitude for the spiritual wants of the population of Prussian Poland.

\section{FO 64/1273: Edward B. Malet to Marquess of Salisbury, No 88, Berlin, 26 March 1892}

[Received 28 March by bag. For: The Queen / Prince of Wales / Mr Balfour; S[alisbury]]

\section{Ministerial crisis; resignation of Zedlitz over elementary school bill}

The Ministerial crisis through which the Government has just passed came upon the public as a complete surprise and there is little doubt that it was equally unforeseen by those principally concerned, for if the Emperor and General Count Caprivi had a prescience of what was coming, it is to be presumed that they would have taken their measures accordingly, and have made such arrangements as would have prevented the public from knowing the dilemma into which they had fallen until it was smoothed.

When the School bill was first submitted to the Prussian Chamber it was approved by the Emperor, but I am assured that His Majesty always held that it must be so modified as to conciliate the moderate party in the Landtag. ${ }^{296}$ In the debates which ensued, the bill encountered naturally the violent opposition of the socialist party and the Chancellor considered himself bound as Prussian Prime Minister to come to the assistance of Count Zedlitz, ${ }^{297}$ the Minister of Public Instruction, who introduced the Bill. He did so with a chivalrous warmth which it is not unfair to say did more credit to his heart than this head, because he shared the opinion of the Emperor that it would be unwise to force the bill upon the country by the sole vote of the clericals and the conservatives. The opposition in the country became louder but the Government continued to think they would be able to make such modifications in the bill that a part of the opposition would be disarmed. It was however at last

${ }^{296}$ The elementary school bill made significant concessions to clerical and Catholic interests; it was introduced in the Prussian house of deputies on 15 January I892.

${ }^{297}$ Malet is here referring to Caprivi's speeches in the house of deputies on 22 and 29 January 1892 . 
perceived that this could only be done by divesting the bill of the clauses which alone made it acceptable to the majority.

Under these circumstances the Emperor presided on the $17^{\text {th }}$ at a crown council. Many rumours have been afloat as to what took place at it - one report says that His Majesty complained that the ministers had not kept him properly informed of the strength of the opposition in the country, and that he spoke with such warmth that Count Zedlitz considered himself personally aggrieved. On the other hand I am assured that His Majesty spoke with perfect moderation but that he said that it would be useless to pass the bill if it only received the votes of the clericals and conservatives as he would not sign it, and that those present apparently acquiesced in the prospect of either abandoning it or changing it. At all events at the conclusion of the council there were no indications of the crisis which followed and the questions of the resignation of any member of the Government was not mooted.

Count Zedlitz however the same evening sent in his resignation and told all his friends that he had done so, and once more Count Caprivi's feelings of chivalry gained the upper hand, for he wrote to the Emperor to say that if Count Zedlitz persisted in his intention he also must resign as he was too far committed to his support of the Count to withdraw it. ${ }^{298}$ The Emperor endeavoured to prevail upon Count Zedlitz to remain by sending him the Chancellor's letter and expressing the hope that such a crisis might be averted - unfortunately no more discretion was exercised with regard to this communication than over the resignation of Count Zedlitz and the crisis at once became of public notoriety.

With regard to the present arrangement by which Count Caprivi lays down the position of Prussian prime Minister and retains the office of Chancellor of the Empire and Prussian Minister for Foreign Affairs, it is to be observed that the post of Prime Minister in Prussia cannot be said to correspond to that of a Prime Minister in England. He does not form his Government as with us. He presides at the cabinet councils, but at these councils matters are decided by a majority of votes and the Prime Minister has only one vote so that he is not more powerful in the deliberations of the cabinet than any of his colleagues. The new arrangement will have one decided advantage and that is that the position of the Chancellor of the Empire will not be affected by the difficulties of the Prussian prime Minister and that there cannot again be a question of his

\footnotetext{
${ }^{298}$ Caprivi handed in his resignation as Prussian minister president and foreign minister, as well as German chancellor, on I8 March 1892. On 24 March he was dismissed as minister president but retained his two other posts.
} 
falling through the mismanagement of matters alone affecting the Kingdom of Prussia.

\section{FO 64/1273: Power Henry Le Poer Trench to Marquess of Salisbury, Very Confidential, No 1 17, Berlin, 29 April 1892}

[Received 2 May. For: The Queen / Mr Balfour / Print (Western Europe) / Embassies; S[alisbury]]

Irritation caused by Times article on Triple Alliance; Marschall claims financial cuts in Italy preferable to a bankrupted state; visit by Italian sovereigns of no political significance

Baron Marschall told me this afternoon that his attention had been called to a Telegram from Berlin, a copy of which is enclosed, which had appeared in yesterday's "Times" regarding the Triple Alliance and the coming of the Marquis di Rudini to Berlin. ${ }^{299}$ It was, he said, a pure invention of the acting correspondent of the "Times" 300 and was almost too ridiculous to contradict. He was annoyed, however, that such a report had been spread, and that a leading English Journal should give credence to such absurd rumours; and expressed a hope that, when "The Times" had a regular correspondent here, the information sent to it would be founded on fact, and not on fiction.

Italy and Austria, Baron Marschall said, were entirely free to increase or diminish, according to the state of their finance, their military and naval forces, and although Germany would be sorry to see any serious reductions in the armaments of those countries, such as might tend to raise the warlike hopes of France and Russia, she would rather have Italy cut down her Army to half its present strength than see her become bankrupt.

The financial condition of Italy was most serious; Signor Crispi had spent far too much money on the Army and Navy, and on railways and other public works; - small economies would now avail nothing: some other means must be found to establish an equilibrium between Revenue and Expenditure; and this, he found, could only be

\footnotetext{
${ }^{299}$ The article dated 27 April (Enclosure: 'The Triple Alliance', The Times, 28 April I892) reported a rumour that the Italian prime minister 'will intimate ... that Italy can no longer support the burden of armaments ... and the consent of the German Government would be necessary before any reduction could be carried out without a breach of Italy's written engagements'. Furthermore, the Italian proposal would be followed by a similar one from Austria. For the Triple Alliance see n. I74 in this section.

${ }^{300}$ Name not traceable. The last correspondent, J.B. Richards, died on 5 April 1892.
} 
accomplished by a serious reduction of her Army, and even the weakening of her Navy.

Baron Marschall referred to various other rumours which had appeared in the Press, in regard to the coming visit of the King and Queen of Italy, and to the political importance attached by some Papers to the meetings between the Sovereigns of Germany and Italy. ${ }^{301}$ The approaching visit, Baron Marschall assured me had no political significance. It had been arranged early in March, and is made in return for the one paid by the German Emperor and Empress ${ }^{302}$ to the King and Queen of Italy at Monza in October I889.

\section{FO 64/1274: Power Henry Le Poer Trench (in the absence of Sir Edward Malet) to Marquess of Salisbury, Confidential, No I81, Berlin, 6 August 1892}

[Received 8 August by bag. For: The Queen / Prince of Wales; S[alisbury]]

\section{Speeches by Bismarck critical of imperial government}

I have the honour to enclose herewith, in translation, Précis of the Speeches made by Prince Bismarck at Jena on the $30^{\text {th }}$ and $3 \mathrm{I}^{\text {st }}$ ultimo. ${ }^{303}$ These speeches, which have been commented on by the entire German Press, are regarded in Government circles as the most important yet delivered by the Prince, and great has been the surprise of the nation at large at hearing that the ExChancellor, who when in power rode roughshod over the Reichstag and expressed the utmost scorn for Parliamentary institutions, should now come forward as the champion of a Parliamentary regime and of constitutional Government and should claim the right to express the sharpest criticism on the advisors of the Emperor.

The Prince, as in his former speeches, again attacks the Chancellor, and the Government have answered these attacks to an article which appeared in the "Norddeutsche Allgemeine

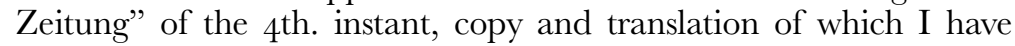
the honour to enclose. ${ }^{304}$

\footnotetext{
${ }^{301}$ Umberto I and Margherita visited Potsdam and Berlin from 20 to 24 June 1892.

${ }^{302}$ Auguste Viktoria.

${ }^{303}$ Enclosures: original cuttings 'Fürst Bismarck in Fena', Post, I August 1892 and untitled extract from Norddeutsche Allgemeine Zeitung, 2 August 1892; précis of Prince Bismarck's speeches at Jena on 30 and 3 I July 1892.

${ }^{304}$ Enclosure: untitled extract, Norddeutsche Allgemeine Zeitung, 4 August 1892 and translation.
} 
The constant reflections and attacks by the Prince on the Centre or Catholic Party have given the latter, who on account of the withdrawal of the School Bill in March last ${ }^{305}$ had refused to support some Government measures, an excuse, they have eagerly desired, for returning to their former allegiance, and they will now give their entire support to Count von Caprivi and to the Government of the Emperor.

\section{FO 64/1274: Power Henry Le Poer Trench (in the absence of Sir Edward Malet) to Marquess of Salisbury, Confidential, No 186, Berlin, I5 August 1892}

[Received 22 August by bag. For: The Queen / Commercial Department; R[osebery], 25 August I892 $]^{306}$

\section{Proposal for International Exhibition in Berlin rejected by broad swathes of German society}

I have the honour to transmit herewith copies and translation of a report made by the Imperial Chancellor ${ }^{307}$ to the Emperor, in consequence of which His Majesty has decided not to adopt the project of holding an International Exhibition in Berlin. ${ }^{308}$

This project was started some months ago and at first met with but little support, except from the class of people who expected to benefit from a large influx of foreigners into Berlin, and the press took very little notice of it. When, however, it became known that France contemplated holding an International Exhibition in Paris in I9oo, the scheme was at once taken up and warmly supported by the Anti-French Party and by those Papers which are hostile to France. On the other hand the more influential and moderate portion of the Press, setting aside politics and sentiment, discussed the matter dispassionately and solely in the interest of German Industry. The Chancellor, in a circular, ${ }^{309}$ referred the project to the several Federal States, when it was ascertained that there were 40 votes against it, 7 for it and I neutral. Opinion is of course divided as to the wisdom of the Chancellor's decision, but it meets with the general approval of the leading newspapers. The majority of the German leaders of Industry, the great employers of labour,

\footnotetext{
${ }^{305}$ See pp. 138--I39.

${ }^{306}$ Archibald Primrose, the $5^{\text {th }}$ Earl of Rosebery, became foreign secretary on 18 August 1892.

${ }^{307}$ Leo von Caprivi.

${ }^{308}$ Enclosures: untitled cutting from Deutscher Reichsanzeiger und Königlich Preußischer Staatsanzeiger, I3 August 1892 and translation.

${ }^{309}$ In early July I892.
} 
and especially the more important manufacturers were either against the project or gave it but a lukewarm support, and on all sides it was considered that the State would in all probability have to bear the greater part of the expense. In short, the intelligent classes and the leading newspapers, after due reflection, came to the conclusion that Germany would gain nothing by adopting the scheme, and recognised that Paris was in every way more suitably situated than Berlin for an International Exhibition.

\section{FO 64/1275: Edward B. Malet to Earl of Rosebery, Confidential, No 227, Berlin, 22 October 1892}

[Received 24 October. For: The Queen / Prince of Wales / Mr Campbell Bannerman / Confidential to Intelligence Division War Office, II November I892; 'The secrecy has broken down', R[osebery]]

Forthcoming army bill designed to close loophole in recruitment of army reserves and draw more young men into military service

On my return to Berlin, on the $18^{\text {th }}$ instant, I went to see Baron von Marschall, and His Excellency told me that nothing had occurred in Foreign Affairs to give any anxiety to Germany during my absence..$^{\text {to }}$

The news of a rupture of relations between Greece and Roumania had just come in, and although the subject which led to the rupture was not of particular importance, the fact that Greece had confided the protection of her Subjects in Roumania to Russia was a circumstance which might produce further complications. ${ }^{31}$

His Excellency went on to say that in Germany the public mind was occupied by the Military Bill, which would be presented to the Reichstag on its assembling..$^{32}$ It would lead to serious discussion but the Chancellor Count Caprivi was of opinion that it would pass.

By the Constitution ${ }^{313}$ every male subject was liable to conscription, but as the strength of the peace establishment was fixed at a certain number, this provision of the Constitution had never been carried out. The result was that, as the populations had increased, the

\footnotetext{
${ }^{3 \text { ro }}$ Malet was on leave of absence from 15 July and stayed at Homburg until Io September when he left for England.

${ }^{11}$ Diplomatic relations were interrupted on 16 October 1892 in the course of the 'Zappa Affair', a dispute over the will of a Greek merchant who had resided and died in Romania in 1865 , and to whose estate the Greek government laid claim.

$3^{12}$ The army bill stipulated a reduction in military service from three to two years (infantry) and allocated supplies for a perpetual peacetime army of 492,086 men (an increase of 72,037 men) for seven years. It was introduced in the Reichstag on 23 November 1892.

${ }^{313}$ Article 57 of the imperial constitution of $187 \mathrm{I}$.
} 
number of men escaping service had steadily increased also, until it had attained the large figure of I00,000 yearly.

The consequence of this would be, that, in case of war, the Government would in the first instance have to call out men who were in reserve and who were mostly married and established in professions; while vast numbers of young men, who were the proper material for the army, were hurriedly being trained to be fit for duty. It was hoped that the alleviation which the bill would bring to the prospects of the Reserve men would render it popular to the masses, and that it would be recognised that the present state of things created an anomaly which ought to be abolished.

The crux would arise through the necessity of finding funds to pay for the large increase of men, but the Chancellor hoped that the patriotism of the Germans was sufficiently strong to enable a majority of their Representatives in the Reichstag to vote them.

I had a conversation with Count Caprivi on the following day, and His Excellency confirmed Baron von Marschall's statement that he hoped and thought that the measure would pass.

The Bill was presented yesterday to the federal Council but its clauses will remain a secret until it is submitted to the Reichstag.

\section{FO 64/1293: Edward B. Malet to Earl of Rosebery, No 5, Berlin, 3 January 1893}

[Received 9 January. For: Chief Clerk / Copy to: War Office; Seen by Chief Clerk [stamped]; 'This is a very important question. Might not the Desp. and Encl[.] I be printed for: Cabinet / War Office / Admiralty / Treasury / Post Office', T.H.S. [Thomas Henry Sanderson]; 'Yes - let me see the Reports in print', R[osebery]; [Printed] i9 January]

Colonel Swaine's report on civil employment of German military; remarks on far-reaching positive effects of military training on working life

I have the honour to inclose herewith a report from Colonel Swaine on the system under which civil employment is guaranteed to soldiers and sailors in Germany on the completion of a certain number of years military or naval service. ${ }^{314}$

The question of adopting a system of this kind in the United Kingdom has already been the subject of attention in Parliament, ${ }^{315}$

${ }^{314}$ The 'civil employment' of German soldiers and sailors was regulated by decrees of Io September I882 and 20 June 1885. Enclosure: report No I by Colonel Swaine on the state employment of all soldiers and sailors, Berlin, 3 January I893.

${ }^{315}$ On io June I892. 
and, as it is one of grave importance, I venture to draw Your Lordship's special attention to Colonel Swaine's report.

Being a civilian I shall not be suspected of prejudice if I bear testimony to the wholesome effect which military training has upon the classes from which soldiers are drawn. In Germany this effect is constantly before one's eyes. In all branches of labour men who have served are preferred by employers on account of their habits of discipline and regularity.

It would be beyond the scope of the subject of Colonel Swaine's report to urge evidence that the military system in Germany gives back-bone to the Empire in the field of trade and industry in peaceful progress and prosperity, but it is allowable to deduce from what is patent here, that if State Employment in the United Kingdom were assured to soldiers of good conduct after the completion of a certain number of years of service, the general public would gain largely through the increased efficiency of the service in those departments to which such soldiers were admitted.

\title{
FO 64/1294: Power Henry Le Poer Trench to Earl of Rosebery, Confidential, No Ir6, Berlin, I9 May 1893
}

\author{
[Received 22 May. For: The Queen / Prince of Wales; R[osebery]]
}

Publication of a letter written by Prince Albrecht of Prussia in favour of reconciliation between Bismarck and the emperor; not the right moment for this course of action

On the $13^{\text {th }}$ Instant the "Vorwärts", the chief organ of the Social Democrats, published a letter dated Blankenburg, May 9, I893, alleged to have been written by Prince Albrecht of Prussia, and addressed to an Excellency whose name was not stated. The Prince, in this letter, of which I have the honour to enclose a translation, ${ }^{316}$ says that Herr von Witzleben, being of opinion that a reconciliation between the Emperor and Prince Bismarck would have a favourable effect on the internal situation in Germany, has asked him to use his influence to get the Prince invited to the ceremony of unveiling the monument to the Emperor William I at Görlitz and thus afford him an opportunity of meeting the Emperor. Prince Albrecht adds that, while he cannot himself interfere officially, he fully recognizes the importance and advisability of such a step and

\footnotetext{
${ }^{316}$ Enclosure: translation of letter by Albrecht of Prussia which appeared in Vorwärts on I3 May 1893 .

${ }^{17}$ The monument was unveiled by Wilhelm II on I8 May I893.
} 
trusts His Excellency will see his way to giving effect to Herr von Witzleben's suggestion.

The "Vorwärts", alarmed at the prospect of such a reconciliation, publishes in the same paper in which appears the letter, an earnest appeal to the Socialists throughout Germany to do their utmost to prevent Prince Bismarck's return to power.

I deferred writing to Your Lordship about this letter before assuring myself of its authenticity, and until I was able to say more about it than was to be found in the Press. I have now ascertained from a thoroughly trustworthy source, that the letter was really penned by Prince Albrecht and was destined for General von Winterfeldt, now commanding the Garde Corps, and who was formerly chief of the Staff to Prince Albrecht. The letter, it is said, never reached its destination, and is supposed to have been stolen at Blankenburg. The "Vorwärts" got it without an envelope and only learnt the day before yesterday for whom it was intended. It tells us nothing new as regards Prince Albrecht's sympathies, for it is well known that he has always been in favour of a reconciliation between the Emperor and Prince Bismarck. His Royal Highness thinks, like many other Germans, that it is much to be regretted that the Emperor should appear to be ungrateful and unfriendly to the founder of the Empire, but forgets that a reconciliation during the present crisis would be humiliating for His Majesty, and prejudicial to the prestige of the Throne. Indeed, Prince Bismarck is reported to have admitted to a friend that, supposing a reconciliation were possible, this would certainly not be the moment to seek to bring it about. The Emperor is not in the least annoyed at such a letter having been written and published, but he has given orders that every effort shall be made to discover who stole it, and the Imperial Secretary of the Post Office ${ }^{318}$ and the Police are taking the necessary steps to trace the thief.

In connection with the above letter it is to be remarked that, for some little time, Prince Bismarck's Papers have ceased to attack the policy of the Emperor.

As Your Lordship is aware, there has always been a Party in Germany who would rejoice to see Prince Bismarck once more at the helm of the State, and there can be no doubt that there is now also a Party, though a small one, which includes even some supporters of the Government, which would welcome the downfall of Caprivi and Miquel. The Chancellor's policy of making Commercial Treaties at the expense, ${ }^{319}$ as they consider it, of the

\footnotetext{
${ }^{{ }^{18}}$ Heinrich von Stephan.

${ }^{319}$ Commercial treaties were concluded with Austria-Hungary, Italy, Belgium, Switzerland (all December I89I and put into effect from February 1892), with Servia
} 
agriculturalists, has incensed a large number of Conservative Landowners. It is an open secret that many of these Conservatives, though willing to support the Army Bill voted with alacrity for the closure, thus signing the death warrant of the late Reichstag. ${ }^{320}$ They hope the next Reichstag will, while favourable to the Army Bill, be strongly protectionist and prevent the conclusion of any more Commercial Treaties on the basis of those already in operation, which they consider so detrimental to their special interests.

\section{FO 64/1294: Edward B. Malet to Earl of Rosebery, No I26, Berlin, 27 May 1893}

[Received 29 May by messenger. For: The Queen / Prince of Wales; R[osebery]]

Unease about composition of future Reichstag; political implications of army bill

Nothing but the most general surmises are as yet afloat as to what will be the composition of the future Reichstag and the result, as is constantly the case in general elections, may upset all calculations. ${ }^{321}$ The general opinion seems to be that the coming chamber will pass the military bill, ${ }^{322}$ but, although this may be counted as a victory for the Emperor and the Government, it will be to some extent counterbalanced by a defeat of their policy in another direction. A Reichstag which will vote the Military Bill will oppose the commercial policy of the Government. The Treaties recently concluded with Roumania and Servia will probably be rejected and the negotiation of a Treaty with Russia will have to be abandoned..$^{323}$

The split in the "Central" or clerical party is complete. A very influential member of it, Freiherr von Schorlemer = Alst, who was the foremost fighter in the Cultur Kampf next to Windthorst, has

(August 1892, effected in January 1894), Spain (August 1893, but not ratified by Spain), Rumania (October I893, in effect from January I894), and Russia (February I894, effected in March I894). All treaties were based on a most favoured nation clause and set to last until 3i December 1903.

${ }^{320}$ The Reichstag was dissolved on 6 May I893. For the rejection of the army bill see n. 322 in this section.

${ }_{321}$ Elections to the Reichstag were held on I5 June $_{1893 .}$

${ }^{222}$ The army bill (see n. $3^{12}$ in this section) and the 'Huene compromise' proposed by Karl von Hoiningen-Huene (which reduced the intended increase of army strength from 72,037 to 59,198 men) were rejected by the Reichstag on 6 May I893. A revised bill was introduced in the newly elected Reichstag on 7 July and passed on I4 July.

${ }^{323}$ The treaty with Serbia was signed on 2I August I892; the treaty with Romania was initialled on 9 April and signed on 2I October 1893. Negotiations with Russia started in October 1893. For the commercial treaties see also n. 319 in this section. 
refused to accept the rejection of the Military Bill as a plank of the "Central" platform. He is a large landed proprietor in Westphalia where he is styled the "King of the peasants", and his example in maintaining his candidature for his former electoral district, ${ }^{324}$ and proclaiming his support of the Bill will be followed by many Catholics.

When I was in England I observed an impression that the crisis in Germany was of so serious a nature that it might be the prelude to great events, tending even towards some Imperial Coup d'État or revolution. There does not appear to be any apprehension of this kind in Germany. The Emperor and the Government have taken the steps which they deemed best calculated to secure the passing of the Bill. They have acted strictly within the limits of the Constitution and there seems to be no sort of apprehension that, if they fail, they will attempt to gain their object by means which would constitute an infringement upon it.

\section{FO 64/1294: Edward B. Malet to Earl of Rosebery, No 185 , Berlin, 31 August 1893}

[Received 4 September. For: The Queen / Prince of Wales; R[osebery]]

Duke of Edinburgh's accession to the throne of Saxe-Coburg and Gotha is generally welcomed

Your Lordship will doubtless have received from Her Majesty's Chargé d'Affaires at Coburg, ${ }^{325}$ reports as to the way in which public opinion in the Duchies has regarded the accession of His Royal Highness The Duke of Edinburgh to the Ducal Throne. ${ }^{326}$

Here in Berlin the public press has, with but few exceptions, hailed the event as yet another tie binding together the two Empires, and has greeted the accession of the new Sovereign with every mark of sympathy and respect.

As a notable exception to this attitude I may refer to an Article published in the Conservative "Reichsbote", ${ }^{227}$ with which it is unnecessary to trouble Your Lordship as it has already been translated by the English Press. [Note in margin: 'See "Times" of Aug. 26. I893']

The "National-Zeitung", one of the principal Berlin Liberal Organs, published on the $27^{\text {th }}$ Instant a leading Article on the

\footnotetext{
${ }^{324}$ Schorlemmer-Alst was candidate for the electoral district Bochum-Witten.

${ }^{325}$ Alexander Condie Stephen.

${ }^{326}$ Alfred succeeded as Duke of Saxe-Coburg and Gotha on 22 August 1893 .

${ }^{327}$ On 26 August the Reichsbote stated that the thought of a foreigner on a German throne was intolerable.
} 
same subject. The writer points out that by the Constitution of $185^{2^{328}}$ the English Sovereign or Heir Apparent would, in the event of there being no other descendant of His Royal Highness The Prince Consort, be entitled to rule over the United Duchies "and for this purpose to appoint a Lieutenant Governor or Stadholder, until such time as the Government could be undertaken by a Prince of the special line of Prince Albert, of age and capable of reigning." After pointing out that the possibility of a personal Union of the Duchies to the British Crown might under certain circumstances still occur, the writer declares that "this possibility must be considered as a political impossibility: the new German Empire is a national selfcontained commonwealth, a state of things which excludes the personal union of any part of the Empire with foreign Powers."

Baron von Rotenhan, the Acting Secretary of State for Foreign Affairs, assured me the other day that The Emperor had been very pleased to be able to testify, by His Majesty's presence on the occasion of the taking of the Oath to the Constitution by the Duke of Edinburgh, ${ }^{329}$ that His Majesty upholds the order of Succession to the Throne of the Duchies; and another distinguished Member of the Government stated in the course of conversation yesterday that the accession of The Duke of Edinburgh will be an additional assurance of practical sympathy between two Empires who have so great an interest in the maintenance of the European peace.

\section{FO 64/1294: Martin Gosselin to Earl of Rosebery, No 197, Berlin, 9 September 1893}

[Received II September by messenger. For: The Queen; Confidential to: Paris / War Office; 20 September; R[osebery]]

\section{Wilhelm II's visit to Alsace-Lorraine appears to have made a good impression}

The visit of the German Emperor to the Reichsland ${ }^{330}$ appears from all accounts to have passed off without a hitch of any sort, and the German press of all shades of opinion are unanimous in recording the good impression produced by His Majesty's presence in Alsace Lorraine. [Note in margin: 'Confidential memo: by Colonel Swaine: 5 Sept: 1893']

\footnotetext{
${ }^{228}$ Article 9 of the constitution of $185^{2}$ (Staatsgrundgesetz fir die Herzogtümer Coburg und Gotha).

${ }^{229}$ Alfred took the oath on 23 August at Reinhardsbrunn Castle. See pp. I52-I53.

${ }^{330}$ Wilhelm visited the Imperial Territory of Alsace-Lorraine from 3 to 9 September I893.
} 
Baron von Rotenhan told me yesterday that the Government were greatly gratified at the cordial reception given to the Emperor and the other German Princes in Lorraine, and specially at Metz, which the Party of Protest have hitherto regarded as their stronghold: and Colonel Swaine, the Military Attaché of this Embassy, who has been residing at Metz all this week, writes word that the enthusiasm of the French-speaking peasantry has been most remarkable wherever and whenever the Emperor has shewn himself.

The Mayor of Ogy, ${ }^{331}$ an old man of 85 years of age, long known for his French sympathies, speaking in French, welcomed His Majesty to Lorraine, and expressed the hope that His Majesty during his short stay in the province would learn "the certainty of our true and loyal feelings, and that God might grant long life to our August Sovereign, and so enable us often to welcome His Majesty to our dear Lorraine".

The Government are specially pleased with the address of Bishop Fleck of Metz, ${ }^{332}$ as indicating that for the future they can count on the cooperation and support of the clergy of the Province.

On the other hand, the speech delivered by the Emperor at the banquet given to the civil authorities of Metz on the $5^{\text {th }}$ instant struck a chord which has reechoed to the furthest limits of the Fatherland:

"Germans you are, and with the help of God and our German Sword, Germans you shall remain."

Following the example of the King of Belgians, the Grand Duke of Luxemburg sent his Minister of State, Herr Eyschen, and the Luxemburg Chargé d'Affaires at this Court, Comte de Villers, to Metz on the $5^{\text {th }}$ instant, to greet His Majesty on his arrival at the frontier fortress.

In my despatch $\mathrm{N}^{\mathrm{o}}$ I8g of the $2^{\text {nd }}$ instant, I alluded to the absence of Colonel Meunier, the French Military Attaché at this Court, from this year's autumn manoeuvres on the French frontier; I have the honour to enclose a Confidential Memorandum for which I am indebted to Colonel Swaine, showing how this silent protest on the part of the French Government is regarded by His Majesty and public opinion in the German Army. ${ }^{333}$

This morning's papers announce that the Prince of Naples ${ }^{334}$ will accompany the Emperor to South Germany and attend the Autumn Manoeuvres of the Wurtemburg Army Corps at

\footnotetext{
${ }^{33^{\mathrm{I}}}$ Monsieur Dory, on 3 September.

${ }^{332}$ On 3 September.

${ }^{333}$ Enclosure: confidential memorandum by Colonel Swaine, Metz, 5 September I893.

${ }^{334}$ Vittorio Emanuele.
} 
Ludwigsburg on the $16^{\text {th }}$ instant. His Royal Highness will be lodged at the Royal Palace.

The foreign Military Attachés have been also invited by the King of Wurtemburg to attend these manoeuvres.

\section{FO 64/1294: Edward B. Malet to Earl of Rosebery, No 216, Berlin, 25 September 1893}

[Received 28 September. For: Chief Clerk (see separate minute); Copy to Treasury (with Lord Dufferin's No 408), 4 October; R[osebery]]

Report on use of Remington typewriter at the embassy

In reply to Your Lordship's dispatch No 229 of the Igth Instant, I have the honour to report that the Remington Type-writer supplied by the Stationery Office has been in constant use at this Embassy for a period of over 18 months.

It is used for signature copies of Despatches and Notes as well as for copies of enclosed documents; and the Imperial Secretary of State for Foreign Affairs ${ }^{335}$ has repeatedly expressed to me his satisfaction at Notes which being addressed to him in type-writing, the clearness of which greatly facilitates the reading and translation.

Although the junior Secretaries have not, of course, attained the speed and proficiency of professional typists, it is nevertheless found that the use of the machine involves a considerable saving of time and labour, and also obviates the possible mutilation of proper names resulting from illegible handwriting.

The staff of Secretaries has not been constant during the abovementioned period, but in spite of this the type-writer has never been entirely neglected; and I am of opinion that with good-will and application anyone may learn it sufficiently in a fortnight to effect a saving of time. The machine has been used by Mr Whitehead, Mr Wyndham and Mr Ian Malcolm, and each of these were soon able to type-write with greater rapidity than they could have copied in a good and clear handwriting.

If I may venture to make a suggestion, however, I would advise that type-writers should only be supplied to Embassies and larger Missions where there are several junior Secretaries, of whom one at least may be expected to familiarize himself with the use of the machine. At the same time I should wish to point out that the machine supplied to this Embassy is apparently inferior to that used in the Foreign Office, the

${ }^{335}$ Adolf Freiherr Marschall von Bieberstein. 
latter having much larger and clearer type, better suited to official correspondence; and I would suggest that machines similar to the Foreign Office type-writer should in future be supplied to Her Majesty's Missions abroad. Whether the Remington is the best machine for official use is a question which can no doubt be fully determined by experience at home, and Her Majesty's Stationery Office is doubtless cognisant of all the most recent improvements.

To illustrate how useful the type-writer has proved, I may mention that a second machine, the property of a member of staff, has also been in use in the Chancery of this Embassy for the last six months.

\section{FO 64/1 295: Martin Gosselin to Earl of Rosebery, No 238, Berlin, I4 October 1893}

[Received i6 October by messenger. For: The Queen; Copy to Admiralty with reference, I6 October I893; C.B.R. [Charles B. Robertson]; R[osebery], I9 October]

Accession of Alfred to throne of Saxe-Coburg-Gotha; reflections on oath and absence of allegiance to empire in all sovereign oaths; explanations concerning sovereigns' ties to the constitution

With reference to [Note in margin: 'Anzeiger, $26 \mathrm{Aug}^{\mathrm{t}}$ I893'] Your Lordship's despatch $\mathrm{N}^{\mathrm{O}} 25^{\mathrm{I}}$ of the $9^{\text {th }}$ instant respecting the form of oath [Note in margin: 'Translation'] taken by Duke Alfred of Saxe-Coburg-Gotha on the occasion of His Royal Highness' accession to the ducal throne, I have the honour to enclose copy and translation of the oath taken by the Duke on the $23^{\text {rd }}$ of August last, ${ }^{336}$ before the Saxe-Coburg-Gotha Ministers of State and officially communicated by the Minister of State, Herr Strenge, to the Common Diet of the two Duchies on the $25^{\text {th }}$ that month. ${ }^{337}$

By this Oath, His Royal Highness swore to observe and defend the Constitution of the Duchies, but no reference whatever is made therein to the relations of the Ducal Government to the Empire.

The Oath, it is true, was taken in the presence of the Emperor, but His Majesty assisted at the ceremony merely as a spectator, and as a mark of affection and respect towards his uncle, the new Sovereign of the Duchies.

No oath of Allegiance is taken either by the King of Prussia or by any of the German Sovereign Princes to the Empire; each German

${ }^{336}$ Alfred succeeded as Duke of Saxe-Coburg and Gotha on 22 August 1893 . Enclosures: oath taken by Duke Alfred of Saxe-Coburg-Gotha upon his accession to the ducal throne printed in Deutscher Reichs-Anzeiger, 26 August I893 and translation.

${ }^{337}$ Both Saxe-Coburg and Saxe-Gotha each had their own Landtag, the joint Landtag consisted of the members of the two assemblies. 
Ruler enjoys an absolutely independent position as far as his individual Sovereignty is concerned, the King of Prussia, as German Emperor, being simply primus inter pares.

According to the Constitution of the German Empire, - dated April I6, I87I - , the German Sovereigns concluded "an everlasting Confederation for the protection of the territory of the Confederation and the rights thereof", ${ }^{33^{8}}$ under the Presidency of the King of Prussia, who, as such, bears the name of German Emperor; and this Engagement is held to bind the successors of all the original parties to the Constitutional Act.

\section{FO 64/1295: Martin Gosselin to Earl of Rosebery, No 246, Berlin, 20 October 1893}

[Received 23 October by messenger. For: The Queen / Confidential to Embassies; 'Pleasant', R[osebery], 23 October]

Marschall on Franco-Russian fêtes; Czar's visit to French ships in Copenhagen seen as a significant gesture; growing Franco-Russian amity

Baron von Marschall, referring today to the Franco-Russian fêtes, said that there was no cause for complaint in the tone of the many speeches which were being made all day long by the French and Russian Orators, and that he hoped that the visit of the Russian officers to Paris would pass off without any untoward incident. ${ }^{339}$

He was much struck by the telegraphic correspondence exchanged between Monsieur Carnot and the Russian Emperor, the former congratulating His Majesty on the profound sympathies uniting the two nations, and receiving in reply a mere expression of the pleasure felt by His Majesty that the Russian Fleet had been able to return the Cronstadt visit. ${ }^{34}$

"On voulait, à ce qu'il parait, mettre pas mal d'eau dans le vin français." "34r

I asked His Excellency what was thought here of the visit ${ }^{342}$ paid by the Cizar to the French Ships at Copenhagen.

He replied that this step was in his opinion far more "significant" than anything which had occurred either at Toulon or Paris. It was

${ }^{33^{8}}$ Preamble of the imperial constitution of $187 \mathrm{I}$.

339 The festivities referred to took place on the first day of the visit of a Russian naval squadron at Toulon from I3 to 28 October; a delegation of 50 Russian officers visited Paris from 17 to 27 October.

${ }^{34^{\circ}}$ The French naval squadron visited Kronstadt between 23 July and 8 August I89I.

${ }^{341}$ French: 'One wished, so it would seem, to water down the French wine.'

${ }^{342} \mathrm{On}$ I3 October I893. 
well known that during his annual outing in Denmark, the Emperor always abstained as much as possible from taking part in public demonstrations, and his visit therefore to the French Ship - and the Salute given to the French Vessels by the Imperial Yacht in a foreign port are the more remarkable. [Note by Rosebury in margin : 'Yes, but all this was not contemplated but forbidden by H.I.M [His Imperial Majesty]]

Baron von Marschall considers that this step on His Majesty's part shows "une habileté hors ligne" ${ }^{\text {"3+3 }}$ on the part of Monsieur Mouraview, the Russian Minister, and Monsieur Pasteur, the French Chargé d'Affaires at Copenhagen.

He has, however, been given to understand that the Danish Court is anxious to dissociate itself from this philo-French Demonstration and that neither the King nor the Crown Prince ${ }^{344}$ accompanied the Emperor on board the French Ship.

"It remains to be seen", the Baron added, "whether Germany or England will be the first to suffer from this Franco-Russian foregathering."

\section{FO 64/1295: Edward B. Malet to Earl of Rosebery, Confidential, No 3o6, Berlin, 20 December 1893}

[Received 25 December by bag. For: The Queen / Print / Western Europe / Paris / Rome; Qy: Admiralty - secret / Lord Spencer; R[osebery], 27 December]

Bülow's appointment as ambassador in Italy due to emperor's intervention; Holstein's views on Italian question; Italy may turn to Russia and France if England unwilling to protect her

The appointment of Herr von Bülow to be German Ambassador at Rome has caused some surprise, as he is junior to nearly all the Chiefs of Mission in the German diplomatic Service. ${ }^{345}$ It is said that his nomination is due entirely to the Emperor and that it was prompted, on His Majesty's part, by the feeling that the state of affairs in Italy is critical and that it was necessary to send thither a man of marked ability to represent Germany at the present juncture.

Monsieur de Bülow is married to a daughter of Madame Minghetti, the widow of the Italian Statesman by her first husband..$^{34^{6}}$ She may, however, encounter difficulty in making her position at Rome, as she is the divorced wife of Count Doenhoff, now German Minister at Dresden.

\footnotetext{
343 French: 'outstanding acumen'.

${ }^{344}$ Frederick.

345 Bülow was appointed on 20 December I883.

${ }^{346}$ Maria von Bülow was the daughter of Domenico Beccadelli di Bologna.
} 
The recall of Count Solms the late Ambassador, has been in the air for some time. I am told that his favour with the Emperor was much shaken by the blunder, intentional or otherwise, of not informing His Majesty of Lord Vivian's Garden Party during the Imperial visit to Rome on the occasion of the silver wedding. ${ }^{347}$

Baron Holstein, the Chief of the diplomatic department at the German Foreign Office, met me in the Street this morning and spoke to me about Italian affairs. He is a man of great intelligence and a very keen politician. In Count Bismarck's time, ${ }^{34^{8}}$ I used often to see him, and got a good deal of news from him, as he talks very openly; but since Baron von Marschall's advent to office he has ceased to receive visits from all heads of missions.

He remarked to me that affairs in Italy were very critical, and that although Signor Crispi came into office with the most reassuring declarations, it was difficult to have complete confidence in the continuity of Italian policy, while it was under his control. ${ }^{349}$ All would depend upon the attitude of Great Britain. Italy had always two policies open to it: - the triple Alliance with its burthens, ${ }^{35^{\circ}}$ or the irredentist programme ${ }^{351}$ with the alluring prospects held out to it by France and Russia, if it would abandon the triple Alliance.

The crucial test was confidence in the safety of its coasts from attacks. Signor Crispi would retain this confidence as long as he could believe that Great Britain would come to Italy's assistance if they were attacked. He would probably soon begin to sound our Foreign Office to see what he had to expect; and Baron Holstein hoped that he might at least receive courteous and not altogether discouraging replies, for he could not help fearing that the day that Signor Crispi was convinced that he had nothing to hope for in that quarter, he would turn his face towards France and Russia.

"But", I said, "Italy is bound by the treaties with Austria and Germany, which have some years to run: she cannot escape from the obligations which these treaties impose." Baron Holstein rejoined that he had not much faith in the efficacy of treaties of this nature if a country did not wish to be bound by them. "If a treaty is to die, it is very useless during the time that precedes its decease".

\footnotetext{
${ }^{347}$ Wilhelm II visited Rome from 20 to 27 April 1883 . Umberto I and Margherita of Savoy's wedding anniversary was on 2I April; the garden party at the British embassy was on 24 April.

${ }^{34^{8}}$ Herbert von Bismarck.

${ }^{349}$ Francesco Crispi took office as prime minister on ${ }_{5} 5$ December 1893.

$3^{35^{\circ}}$ For the Triple Alliance see n. 174 in this section.

${ }^{35^{1}}$ The Italian irredentist movement demanded the cession of the Italian speaking parts of Austria-Hungary to the Italian kingdom.
} 


\section{FO 64/1325: Edward B. Malet to Earl of Rosebery, Secret, No 25, Berlin, 3 February 1894}

[Received 5 February. For: The Queen / Lord Spencer J.; Print (Brazil) vol only; $\mathrm{R}$ [osebery]]

Meeting with Wilhelm II at opera ball; emperor threatens Brazilian minister that German war vessels will fire on Rio if threatened again

With reference to my Despatch $\mathrm{N}^{\mathrm{o}} 24$ of this day's date reporting that Baron von Marschall had spoken to me about the situation at Rio de Janeiro, ${ }^{35^{2}}$ I have the honour to inform Your Lordship that, at the Opera Ball last night, The Emperor, during his usual visit to the box allotted to the Ambassadors and Ambassadresses, in the course of conversation with the former (we were all standing round His Majesty) fell upon the same subject, and he told us that he had spoken "carrément" 353 about it to the Brazilian Minister, Baron Itajuba, at the Court Ball which took place on the $3^{\text {st }}$ Instant. His Majesty said that he had told the Minister that the German war vessels would blow the town of Rio to pieces if the Brazilian Government batteries fired again upon their boats, and, His Majesty added laughing, that he thought he had given the Minister a good fright.

In this assumption I fancy that His Majesty was correct, for it has come to me from another source that, after the Ball, Baron Itajuba stayed up till three in the morning telegraphing to his Government.

\section{FO 64/1325: Edward B. Malet to Earl of Kimberley, Secret, No 53, Berlin, 24 March 1894}

[Received 26 March by bag. For: Lord Rosebery / Chancellor of the Exchequer / Commercial Department; K[imberley]]

Conversation with Baron von Marschall on advantages and implications of Russo-German commercial treaty

With reference to Your Lordship's Despatch No. 83 Secret of the 2oth inst, requesting me to ascertain the opinion of members of the German Government as to the relative advantages gained by Russia and Germany by the Commercial Treaty and the object of Russia in making one from which it could derive so little benefit, I

${ }^{35^{2}}$ Malet is referring to the second Brazilian naval revolt against the central government in Rio de Janeiro which broke out in September I893 and was suppressed in March I894. Wilhelm II was sympathetic to the allegedly royalist insurgents.

${ }^{353}$ French: 'bluntly'. 
have the honour to inform Your Lordship that I spoke to Baron von Marschall on the subject to day. ${ }^{354} \mathrm{He}$ is the member of the Government who is most qualified to speak on the subject, as he defended the Treaty in the Reichstag ${ }^{335}$ and in conjunction with the Chancellor ${ }^{35^{6}}$ has borne the burthen of the fight and reaped the spoils of victory, the Emperor having bestowed upon him ${ }^{357}$ the Grand-cross of the Red Eagle.

He acknowledged that he honestly considered that the advantage was nearly all on the German side. I then asked His Excellency what was the motive which induced the Russian Government to conclude it. He replied that a large preponderance of public opinion in Russia considered that Russian grain would find its market in Germany and that the leading object of the Russian Government was to conciliate those who held this view.

I said the prices of grain in Germany rendered this hope illusory. His Excellency replied that in the case of wheat and barley it was so, but that oats would find a ready and immediate market here.

I then asked His Excellency whether general political considerations might not have something to do with it; whether the Russians had not acted in the interests of peace; whether they had not wished to make a counterpoise to the French-Russian Rapprochament, feeling that the latter might carry them further than was intended. His Excellency said that he had not heard anything to lead him to suppose that this had entered into the calculation of the Russian Government, but that he was of opinion that the Russians and the Emperor especially were somewhat out of conceit with their French friends.

I then suggested another possible motive to His Excellency; I asked whether if the negotiations had not been brought to a successful issue it would not have been a very serious outlook for both countries? To this Baron von Marschall assented. He said that continuance of the tariff war would have been frought $[s i c]$ with dangers for both - the customs duties being so onerous gave rise to smuggling on a large scale. As long as the negotiations were going on, the customs authorities on both frontiers were, as it were, authorised to be lax in the observance of its most rigorous terms. If the negotiations had been broken off, continuous frontier trouble would have been the result,

\footnotetext{
354 The commercial treaty with Russia - based on a most favoured nation clause - was concluded on Io February I894 and passed by the Reichstag on I6 March. It came into effect on 20 March.

${ }^{355}$ On 26 February 1894.

${ }^{356}$ Leo von Caprivi.

${ }^{357}$ On 20 March I894.
} 
armed collisions would probably have taken place and the ill-will of the two nations towards each other would have grown apace. He considered that the continuance of the customs war would have been distinctly dangerous to peace between Germany and Russia. $\mathrm{He}$ added that it would have ruined the German Ports on the Baltic and that he was grateful to these towns, Dantzig, Lubeck etc. for their attitude during the negotiations, for had they proclaimed their danger it would have been a strong weapon in the hands of Russia to win further concessions from Germany.

\title{
FO 64/1333: Edward B. Malet to Earl of Kimberley, Africa, No 47, 14 April 1894
}

\author{
[Received I6 April by bag. Print (Niger I); i7 April $]^{35^{\circ}}$
}

Colonial affairs in Cameroon's hinterland causing thomy Anglo-German relations; draft note for German government; useful relationship between German head of colonial department and secretary of embassy

I have the honour to acknowledge the receipt of Your Lordship's Despatch $\mathrm{N}^{\mathrm{o}}{ }_{3} 6$ [Note in margin: 'Africa'] of I I $^{\text {th }}$ instant on the questions arising out of Agreements lately concluded by Germany with Great Britain and France affecting the Cameroons Hinterland. ${ }^{359}$

Your Lordship instructs me to be guided generally in my communications on the subject by the terms of this Despatch, and Your Lordship empowers me to communicate to the German Government the revised regulations for the navigation of the Niger which are inclosed in it. ${ }^{360}$

\footnotetext{
${ }^{35^{8}}$ Notes on docket: 'This draft note is good and civil, but it would be certain to be answered, perhaps unpleasantly. Our real object is to anticipate a joint attack by Germany and France resp[ecting] the Niger Navigation. It might be best that Sir E. Malet should send the regulations with a note in the sense of the bracketed passages of the draft and speak in the sense of the remainder when he thinks it advisable.' H.P.A. [Henry Percy Anderson]; 'I quite agree. The note would only irritate and produce a long winded reply in the "best" German Chancery style.' K[imberley], I8 April; 'Dft [draft] accordingly', 2I April].

${ }^{359}$ Malet is referring to the German agreement with Great Britain of ${ }_{4}$ April and I5 November 1893 respecting the borders of the German Cameroon colony, and the agreements with France of 4 February and I5 March I894.

${ }^{360}$ The revised regulations for the Royal Niger Company were issued on I9 April I894. According to Kimberley, in his dispatch to Malet of in April I894, these regulations were 'at least as favourable to foreign trade as those [that] apply to any other river open to general navigation'. Notwithstanding German accusations against the Niger Company and complaints that navigating the Niger was 'next to impossible', 'Great Britain as the riparian Power, has done its utmost to assist the passage of vessels engaged in peaceful commerce'.
} 
The action of the German Government has been so little frank or friendly in the matter of the French negotiations, that I am inclined to think that it would be well to place our appreciations of the course they have chosen to pursue on record in a Note to Baron von Marschall with such reticence as becomes a State Paper, and bearing in mind that we prefer cooperation with Germany in Africa to continued rejection of proposals which one Government may make to the other, and that therefore the general design of the note should rather be to disarm future opposition than to widen the breach by the exposure of the naked truth.

I venture to submit herewith to Your Lordship a draft of a Note which I have drawn up on these lines, and to submit it for Your Lordship's emendation in case You should agree in the advantage of writing such a Note at all. ${ }^{61}$

I have omitted all mention of $\mathrm{D}^{\mathrm{r}}$ Kayser and his remarks. ${ }^{362}$ The position in regard to this gentleman is a difficult one. The Ambassador can only communicate with Baron von Marschall, the Secretary of State, but as His Excellency practically leaves the whole direction of African Affairs to $\mathrm{D}^{\mathrm{r}}$ Kayser, who is the head of the Colonial Department, it has been found convenient that Her Majesty's Secretary of Embassy should have access to the latter, and, as $\mathrm{D}^{\mathrm{r}}$ Kayser is tolerably communicative, the system has been useful in keeping us to some extent in touch with the views prevailing [in] German Colonial policy. If however the information gained in this manner were brought up against $\mathrm{D}^{\mathrm{r}}$ Kayser, it is probable that he would decline to see $\mathrm{M}^{\mathrm{r}}$ Gosselin any more, and we should lose a very convenient medium of communication on colonial affairs - the only one, in fact, which we possess, for my conversations on these matters with Baron von Marschall are usually treated by His Excellency as ad referendum ${ }^{363}$ to $\mathrm{D}^{\mathrm{r}}$ Kayser.

If Your Lordship does not approve of engaging in a polemic with the German Government which may be the result of sending in such a Note as I have drafted, I would propose to send to Baron von Marschall a draft of the revised regulations of the Niger Navigation without comment beyond such as I may make verbally in speaking of the matter to His Excellency.

${ }^{36 \mathrm{r}}$ Enclosure: Draft, Malet to Marschall, Berlin, April I894.

${ }^{362}$ Malet is probably referring to Kayser's complaints about the attitude of the Royal Niger Company, which he made in a conversation with Martin Gosselin on 6 April I894.

${ }_{363}^{63}$ Latin: 'for further consideration'. 


\section{FO 64/1333: Martin Gosselin to Earl of Kimberley, Africa, No 63, 26 May 1894}

[Received 28 May. For: The Queen / Lord Rosebery / Chancellor of the Exchequer; Cabinet; Print / Paris, P.L. [printed letter], No. 179, 31 May / Brussels; P.L. [printed letter], No 56, $\left.3^{\circ} \mathrm{May}\right]^{364}$

\section{Reflections of Paul Kayser on Anglo-Congolese agreement}

Doctor Kayser having asked me a few days ago whether I had yet received the text of the Agreement between Great Britain and the Congo State, signed at Brussels on the $12^{\text {th }}$ inst., I called on him yesterday and showed him the text which I had received the night before in Your Lordship's Despatch No. I8 Treaty of the $23^{\text {rd }}$ inst. ${ }^{365}$

He thanked me but added that he had received the document that morning from the German Embassy in London, and had evidently lost no time in studying its contents, as I noticed that the new boundaries were pencilled out on the map hanging up in his room.

Doctor Kayser remarked that the agreement had come upon him as a surprise; and that at first sight it seemed to involve a novel principle in international law. Would it be possible for Belgium or Switzerland to "Lease" part of their territories which had been neutralized under an international guarantee ${ }^{366}$ Yet this is what apparently has been done by King Leopold.

As for the novel system of leasing territories for "a period to be hereafter determined", Doctor Kayser said that in his opinion it would be difficult to differentiate it from a cession, but added that he had not had time as yet to master all the details of the Anglo-Congo[1]ese Agreement.

We then proceeded to discuss other matters, but on rising to take leave of me, he went to the map, and pointing to the strip of territory

\footnotetext{
${ }^{364}$ Note on docket: 'Sir E. Hertslet as to the point of international law. As reflecting the views of the Colonial Office the articles are not satisfactory.' C.L1.H. [Clement Lloyd Hill]; 'We must await what the German Govt may say after more mature reflection. The point of international law is not made officially. There are two mistakes. The frontiers of the Congo State have not been settled by international agreement. The frontier with the German sphere will not be altered unless our road runs along it which is unnecessary. It should be an interior road.' H.P.A. [Henry Percy Anderson], 20 May; 'The Germans did not consult us when they gave the French access to the Niger.' K[imberley], 29 May.

$3^{65}$ The treaty with Leopold II of I2 May I894 settled the limits of the Congo Free State. It granted the Congo access to the Nile valley (while recognizing British sovereign rights) and stipulated the lease to Britain of a corridor of land from Lake Tanganyika to Lake Edward, thus linking British 'possessions' in southern Africa and Uganda.

${ }^{66}$ On the basis of the Final Act of the Berlin West Africa Conference (26 February 1885) Leopold II declared the Congo Free State to be permanently neutral; its neutrality, however, was not internationally guaranteed.
} 
extending from Lake Tanganyika to Lake Albert Edward, said: "Your Government wish to be our neighbour here as elsewhere but who knows whether the plan can be carried out?"

I think it right to report Doctor Kayser's observations to Your Lordship, though made, as he expressed it, merely as to a friend; the more so as the newspapers which have as yet referred to the new agreement generally concur in considering that German interests have been thereby injured. Even the Vossische Zeitung, which always adopts a moderate tone in colonial matters, ends up an anti-English article ${ }^{367}$ by saying that the creation of an English "girdle" northwards from Tanganyika has brought German interests nearer to France with whom Germany has never yet had any dispute in Africa.

I have the honour to enclose precis of two articles in the National Zeitung ${ }^{368}$ which I have reason to believe reflect very faithfully the views of the Colonial Department on the subject.

\section{FO 64/1325: Edward B. Malet to Earl of Kimberley, Secret, No I17, Berlin, I4 July 1894}

[Received I6 July by bag. For: The Queen / Lord Rosebery / Chancellor of the Exchequer / Cabinet / Paris; K[imberley]]

Remarks on Caprivi's chancellorship; emperor's compassionate release of imprisoned French officers following the assassination of President Carnot of France

I have said in my Despatch No. in6 Secret of this day's date that as long as General Caprivi is Chancellor, I do not think that we shall be exposed to a policy of surprises on the part of Germany.

A rapprochement with France would however certainly be a surprise and the recent action of the Emperor on the occasion of $\mathrm{M}^{\mathrm{r}}$ Carnot's assassination has been considered by some to indicate a desire of His Majesty in this direction. ${ }^{369}$

I am not inclined to take this view. I regard His Majesty's feeling telegraphic messages ${ }^{370}$ as the genuine and spontaneous expression of horror at the crime and sympathy with the widow.

In regard to the liberation of the French officers imprisoned at Glatz, I am informed by Monsieur Herbette, the French

${ }^{367}$ On 25 May I894.

${ }^{668}$ Enclosures: précis of article 'England's agreement with the Congo State', National Zeitung, 25 May 1894; précis of article 'Germany, England and the Congo State', National Zeitung, Evening Edition, 25 May I894.

${ }^{369}$ On 24 June Carnot was stabbed by an Italian anarchist and died the following day.

${ }^{370}$ Telegram to Cécile Carnot of 25 June I894. 
Ambassador, that this act of clemency was due to His Excellency's intercession and did not emanate from the Emperor's own inspiration. ${ }^{371}$

Monsieur Herbette was ordered to Kiel ${ }^{372}$ to thank His Majesty for his messages of condolence and he took advantage of a private audience to urge upon His Majesty the opportunity of releasing the two French officers on the occasion of Monsieur Carnot's funeral. At first the Emperor said it was impossible, but he was gradually persuaded by Monsieur Herbette who spoke of the unhappy circumstance of an aged mother of one of the officers ${ }^{373}$ who could not travel and feared that she would never see her Son again. The Emperor's heart was touched. He promised to telegraph to General Caprivi to come to him immediately. The Chancellor arrived at Kiel the following morning which was Saturday. Having decided with the Chancellor that the thing should be done, the Emperor did not neglect the "mise en scène" from his Imperial act of clemency which was announced the next day to President Casimir Perier immediately before the funeral. ${ }^{375}$

The action of the Emperor has undoubtedly produced a diminution of tension between France and Germany, but it was not the result of a settled policy and will probably not have a lasting effect.

\section{FO 64/1326: Martin Gosselin to Earl of Kimberley, No 147 , Berlin, Io September 1894}

[Received i3 September. For: The Queen / Prince of Wales / Lord Rosebery; $\mathrm{K}$ [imberley]]

Conservative Kreuzzeitung on emperor's appeal to nobility in his speech at Königsberg; Prussian nobles proclaim loyalty to throne but persist in opposition to Caprivi's commercial policy

The "Kreutz Zeitung", the organ of the extreme Conservative Party, took two days to consider the pronouncement made by His Majesty at Koenigsberg on the $6^{\text {th }}$ Instant, before venturing to do more than to reproduce the text of the speech.

${ }^{371}$ On I July Wilhelm II pardoned Robert Degouy and Jacques Delguey de Malavas two French naval officers who, in December I893, had been sentenced to six and four years imprisonment respectively for espionage.

${ }^{372}$ Herbette visted Wilhelm II on 28 June I894.

${ }^{373}$ Jacques Delguey de Malavas.

${ }^{374}$ French: 'staging'.

375 The funeral was on I July. 
After the lapse of 48 hours, and, it may be presumed, after consultation with the Agrarian leaders, the Conservative organ publishes a leading article in the following sense:

The Conservatives, whether nobles or commoners, have never yet opposed their King: this would indeed be "an absurdity". They have merely voted against the responsible servants of the Crown, when convinced of the harmfulness of the Ministers' policy. Such a course is the right and the duty of the most faithful of subjects. It is not so much the attitude of the nobility towards the Commercial policy of the Government, as the form which this opposition has taken, which has grieved His Majesty; and the "Kreutz Zeitung" is fain to admit that "in the heat of the fray" this may have here and there overstepped the bounds of propriety. His Majesty is pleased himself to recognize the "heavy cares" which weigh on agriculture, and the "Kreutz Zeitung" must add, "with all loyalty," that the manners "and method adopted by the Imperial Chancellor and other responsible servants of the Emperor towards this "heavy care" has not been calculated to temper or render more moderate the complaints on the subject."

If the above should turn out to be the last word of the Agrarians, the Sovereign's conditional promise to let bye-gones be bye-gones will certainly not be realized.

The Prussian Constitution of $1850{ }^{376}$ it is true, proclaims the equality of all in the eye of the law; but the feelings and customs of centuries are not be wiped out by even so solemn a document as a Constitution. The Kings of Prussia have ever regarded their Nobles as forming a privileged Class apart, closely bound to the fortunes of the House of Hohenzollern; this feeling has hitherto been fully reciprocated, and in no part of the Monarchy are feudal traditions and aspirations so thoroughly rooted amongst all classes of the population as in the Provinces of East and West Prussia.

It cannot be gainsaid that exceptional privileges have been reserved to the Prussian Aristocracy; the Army List, the Civil Service, the Protection, even under the regime of the new Commercial Treaties, ${ }^{377}$ still accorded to the landed interest, all testify to this; and His Majesty clearly indicates that in return for these privileges $\mathrm{He}$ expects that the beneficiaries will cease their opposition, and loyally support a policy which is for the benefit of the whole Community. The "professional" opposition of the various political parties in the State is only what is to be expected; it is their right, and they legally exercise it; but the "Monarchy by Divine Right"

\footnotetext{
${ }^{376}$ Article 4 .

${ }^{377}$ For the commercial treaties see nn. 3 I9 and 354 in this section.
} 
expects that those standing nearest to the Throne will give a loyal support to measures judged necessary for the Common Weal.

His Majesty has now once more solemnly warned the Prussian Nobles that Count Caprivi's Commercial policy is His own: and that it is His wish that Germany should enter into closer Commercial relations with her neighbours; yet in spite of this solemn warning the "Kreutz Zeitung" after 48 hours' cogitation, has nothing else to reply than that the Conservatives have never opposed the Sovereign, but only His Ministers, and incorporates in the answer another attack on Count Caprivi.

It remains to be seen whether the leading Conservatives will submit with a good grace to the clearly expressed wish of their Sovereign, or whether they will continue their opposition to the Chancellor and all his works and hostility to the Imperial Government, which is apparently the policy still upheld by the most influential organ of their party.

\section{FO 64/1326: Martin Gosselin to Earl of Kimberley, No I88, Berlin, 28 October 1894}

[Received 3o October by post. For: The Queen / Lord Rosebery / Chancellor of the Exchequer; K[imberley]]

Hohenlohe-Schillingsfürst set to be new imperial chancellor and Prussian prime minister; remarks on his career to date; Caprivi glad to be moving on from Berlin

In continuation of my Despatch N. I86 of yesterday, I have the honour to state that it appears certain that Prince Hohenlohe-Schillingsfürst, the Statthalter of Alsace-Lorraine, will be appointed Imperial Chancellor and Prussian Prime Minister, and that Herr von Köller, who has for some time past been His Highness' right hand man as Under Secretary of State for the Reichsland, will receive the seals of the Prussian Ministry of the Interior, hitherto held, together with the Premiership, by Count Eulenburg. ${ }^{37^{8}}$

There can be no doubt that the Emperor had these appointments in view when His Majesty summoned, on Friday evening, the Prince and Herr von Köller from Strasburg to Potsdam, and, though no official announcement has yet been made, the fact that Prince Hohenlohe called this morning at the Ministry for Foreign affairs and visited, among others, Baron Holstein, the Political Director of

\footnotetext{
${ }^{378}$ Hohenlohe-Schillingsfürst and Köller were appointed on 29 October 1894. For Caprivi's resignation as chancellor see the following dispatch.
} 
that Department, tends to show that His Highness has accepted the charge which His Majesty desires to entrust to him.

Prince Chlodwig Hohenlohe, who is now in his $76^{\text {th }}$ year, has had a long experience of public life. From January i867 to March I87o he was Bavarian Minister President in the Liberal administration, and as first Vice President of the Customs Parliament and of the German Reichstag from I867 to I874, has acquired considerable Parliamentary experience.

In 1874 he succeeded Count Harry Arnim as German Ambassador in Paris, and, during the eleven years which he held that post, he did much to improve the official relations of the two countries.

For some months in I880, during Prince Bismarck's illness, he took over the work of the Imperial Foreign Department, and acted on behalf of the Chancellor in the Government and in Parliament.

For the last nine years he has held the important post of Statthalter of Alsace-Lorraine, and has done much to reconcile the population to German rule in the Reichsland.

Colonel Swaine informs me that he met Count von Caprivi in the street this afternoon, who stopped him to say goodbye, adding "I am going at once to Switzerland to rest and recruit. I am glad to get away from this atmosphere and these surroundings. They were too much for me".

\section{FO 64/1326: Martin Gosselin to Earl of Kimberley, Very Confidential, No r9I, Berlin, 3o October 1894}

[Received I November by post. For: The Queen / Lord Rosebery / Chancellor of the Exchequer; K[imberley]]

Conversation with Bavarian minister Lerchenfeld on Caprivi's resignation and Hohenlohe's nomination as imperial chancellor

I called yesterday on Count Lerchenfeld, the Bavarian Minister in Berlin, and asked him whether he could give me any details of the recent Chancellor crisis.

His Excellency, who, by his position as Representative of the second largest German State, by his long residence here and by his personal capabilities, has quite exceptional opportunities of knowing what is going on, told me that Count von Caprivi's resignation ${ }^{379}$ came to him, as to all the rest of the world - as a complete surprise.

\footnotetext{
I894.

${ }^{379}$ Caprivi handed in his resignation on 23 October and was dismissed on 26 October
} 
The Chancellor, had only last Wednesday, submitted to the Bundesrath $^{380}$ his programme for strengthening the hands of the Executive against the "Parties of Disorder", - submitted, not as a Prussian proposition, but as one emanating from himself as President (a "Präsidial-Vorschlag" as it is called here): this proposition had been discussed and unanimously agreed to by the Bundesrath, and was, moreover, Count Lerchenfeld added, approved by a large majority of the Prussian Cabinet. ${ }^{31}$

When the Representatives of Bavaria, Saxony, Wurtemberg and Baden $^{322}$ were summoned by His Majesty to the Schloss on Friday afternoon, ${ }^{383}$ immediately after the Emperor's interviews with Count von Caprivi and Count Eulenburg, he, Count Lerchenfeld, had no idea that the Chancellor had resigned, much less that his resignation had been accepted: and it was from the Emperor's own lips that they were made acquainted with the fact.

His Majesty took pains to explain to the four Ministers that $\mathrm{He}$ entirely approved of Count von Caprivi's draft proposal, already sanctioned by the Bundesrath, - that it was simply a change of Ministers that had occurred, rendered necessary by the dissentiments [note above in pencil: 'dissensions'] which could no longer be tolerated, and that the internal policy of the Imperial Government would in no way be modified.

Count Lerchenfeld said that, of course, it would depend on the new Chancellor whether the proposed programme would be presented intact to the Reichstag - with or without modification, but he answered me that Count von Caprivi's scheme was entirely endorsed by himself and his colleagues in the Bundesrath.

In reply to my enquiry whether Prince Hohenlohe, if nominated, ${ }^{3{ }^{84}}$ was of an age to support the double burden of the Chancellorship and the Premiership, which had proved almost too much for Prince Bismarck, His Excellency replied that he thought, under the circumstances, no better appointment could be made: he trusted that the new Chancellor would hold himself more "à l'écart"

\footnotetext{
${ }^{380}$ Federal Council, on 24 October 1894.

${ }^{38 \mathrm{r}}$ The so-called 'subversion bill' (bill for the amendment and amplification of the Criminal Code, the Military Penal Code, and the Press Law), drafted by the Imperial Office for Justice and more moderate than Eulenberg's proposal, was discussed in the Prussian council of ministers (Staatsministerium) on Ig October and found approval in the Federal Council on 25 October i894. It was introduced in the Reichstag on 5 December I894 and subsequently rejected on II May 1895.

${ }^{882}$ Hugo Graf von Lerchenfeld, Wilhelm Graf von Hohenthal, Axel Freiherr Varnbüler, and Eugen von Jagemann.

${ }^{383}$ On 26 October I894.

${ }^{384}$ Hohenlohe was appointed on 29 October.

${ }^{385}$ French: 'at a distance'.
} 
than his predecessor; Parliamentary Government was not the same here as in England: there is no necessity for the Chancellor to be continually interfering in the Reichstag debates, he should rather keep himself in reserve for cases of extreme necessity. If Prince Hohenlohe adopted this practice, he thought, he could very well undertake, even at his age, the supreme direction of the Imperial and Prussian Governments.

The Emperor has been severely criticized in more than one quarter for having thrown overboard a public servant, with whose policy His Majesty is still supposed to have been in entire agreement, but, if the state of affairs is examined dispassionately, it seems to me that, on the supposition that the Chancellor and the Premier ${ }^{36}$ could no longer work together, no other course could have been adopted.

Had His Majesty determined to stand at all risks by his Chancellor, and accepted Count Eulenburg's resignation alone, all the agrarian party, and the Conservative forces in East and West Prussia, would have been up in arms at what would have rightly been considered the abandonment of their champion in the Councils of the Sovereign.

Had His Majesty, on the other hand, accepted the Chancellor's resignation without that of the Prime Minister, it would have been regarded throughout all Germany as a sign that a strong reactionary policy was again to be adopted. Moreover, by accepting the resignation of both Ministers, His Majesty is enabled to do away with the dualism which has, during the last six months, become almost a public scandal.

The successor to Prince Hohenlohe in the Statthaltership of Alsace-Lorraine has not yet been gazetted. It was the Emperor's intention, I am told, to offer it to Count Eulenburg, but difficulties have since arisen with regard to His Excellency's nomination, and it is now rumoured that Prince Hohenlohe-Langenburg, is the probable candidate for the post.

Other changes in the Prussian Cabinet are spoken of, but nothing is yet known positively on the matter.

I do not like to close this Despatch without informing Your Lordship that the Press of all shades of opinion, official, Catholic, Liberal and Radical, with the single exception of the extreme agrarian organs, bear hearty testimony to the honesty of purpose and singleness of mind which have been the distinguishing marks of the late

\footnotetext{
${ }^{386}$ Eulenburg, who, in contrast to Caprivi, was prepared to impose anti-socialist measures and advocated a coup d'état against the Reichstag, resigned as Prussian minister president on 24 October and was dismissed on 26 October.
} 
Chancellor during the four years he has held the post of Imperial Chancellor.

\section{FO 64/1334: Martin Gosselin to Earl of Kimberley, Africa, No 134, Berlin, 7 November 1894}

[Received 9 November by post. For: Lord Rosebery / Colonial Office; 'It has been from the first in this direction that there is hope of better African relations with Germany', H.P.A. [Henry Percy Anderson], 9 November; 'Satisfactory', K[imberley], in November]

Positive reports of cooperation between German and British directors of the South West African Company

The papers announce that the question of improving the landing place at the Swakop Mouth in German South West Africa has been discussed this week at the Ministry for Foreign Affairs ${ }^{387}$ by Representatives of the Colonial Department, the South West African Colonial Society, the Hanseatic Land, Mining, and Trading Society for South West Africa, the South West African Emigration Society, and the South West Africa Company, the latter Company being represented by Mesrs. George Cawston, Davis and Gaill[sic]. ${ }^{388}$

It was eventually decided that a technical engineer, to be appointed by the Foreign Office, should be sent to South West Africa by the Foreign Office to draw up a report on what had best be done in the matter, the expenses being met half by the Government and half by the Societies interested in the Colony.

The Kreuz Zeitung of yesterday, in announcing this decision says that the moderation displayed by the English Representatives is another proof that "the fears connected with the establishment of the South West African Company went too far. ${ }^{39}$ The English Members of the Company have from the very beginning proved themselves uniformly loyal, and admit without reserve the German Sovereignty and Administration, and take the liveliest interest in all improvements in the Territory, even when such entail on them expenditure. So much cannot be said of many other entirely German Companies."

It is not often that the Conservative organ bestows such unstinted praise on anything connected with British undertakings in Africa,

\footnotetext{
${ }^{387}$ On 5 November 1894.

${ }^{388}$ Probably H. Gale, director of Railway and Works Contractor Ltd.

${ }^{889}$ The South West Africa Company Limited, an Anglo-German joint venture in German South West Africa, was founded in 1892 under English law and had its headquarters in London.
} 
and I am therefore the more pleased to place on record the success which has attended the visit of Mr Cawston and his friends to Berlin.

It may reasonably be hoped that the harmonious cooperation of the British and German Directors of the South West Africa Company may tend to bring about a more cordial feeling in this country towards British Colonial enterprise, and so unite the interests of the two countries in South Africa.

Mr Cawston, who seemed well pleased with his reception by Dr. Kayser, told me this morning he meant to return direct to London, and will doubtless cause Your Lordship to be informed of the result of his negotiations.

\section{FO 64/1326: Edward B. Malet to Earl of Kimberley, Confidential, No 256, Berlin, 8 December 1894}

[Received io December by bag. For: The Queen / Lord Rosebery; Print (Samoa); Qy: Cabinet; K[imberley]]

Conversation with Marschall about colonial matters; article in the Standard on Germany's isolation in international affairs has rankled

I have the honour to inform Your Lordship that I saw Baron von Marschall yesterday and had my first conversation with him on general matters since my return from England. ${ }^{39^{\circ}}$ His Excellency's language was couched in an entirely different tone from that of Doctor Kayser, reported in my despatch $\mathrm{N}^{\circ}{ }_{5} 5 \mathrm{O}$, Africa, confidential, of the $2^{\text {nd }}$ instant. He began by saying that the situation reduced itself to a journalistic war, in which, to his mind, neither party conceded enough to the relative internal exigencies of either country and he attributed the violence of the German press to the extreme irritation caused by the article in the Standard on the isolation of Germany. ${ }^{391}$

I have no doubt that this is in a great measure true. The article was like putting a finger into a secret wound which Germany felt but hoped to keep concealed.

I replied that the Standard was a Conservative organ and could not be supposed to represent the views of Her Majesty's Government. Baron von Marschall acknowledged this but said that the article was looked upon as a sign of the feeling in England regarding Germany and therefore produced extreme annoyance.

\footnotetext{
${ }^{39 \circ}$ Malet was on leave from i6 October to 26 November 1894 .

${ }^{391}$ Marschall was referring to the editorial in the Standard of 12 November I894. It pointed to the imminent isolation of Germany on the basis of Rosebery's Guildhall speech on foreign policy of 9 November, and the Anglo-Russian agreement on Central Asia.
} 
He then touched lightly on the three points of Delagoa Bay, Samoa and Togo. What he said in regard to the latter Your Lordship will find in my Despatch $\mathrm{N}^{\mathrm{O}}{ }_{\mathrm{I}} 5^{2}$ of today, of the African series.

In regards to Delagoa Bay, he said that the German Government only desired the maintenance of the Status quo; they objected to encroachments of $\mathrm{M}^{\mathrm{r}}$ Cecil Rhodes on the sovereignty of Portugal, or the commercial independence of the Port or of the Railway. ${ }^{392}$

In regard to Samoa, he went over the old ground, and said that Germany had always hoped that Her Majesty's Government would have regarded the matter in the same light as Lord Salisbury did in I887, when the opposition of the United States was the only bar to the Islands being placed under a German Administration as long as German interests there remained preponderant. ${ }^{393}$

The opposition of the United States was now withdrawn, ${ }^{394}$ and he could not see that the situation was changed so as to render it impossible to follow the course now, which, in the opinion of Her Majesty's Government at that time, offered the best chance of a satisfactory solution of the question.

In regard to what passed in I887, it may be useful to refer to the confidential print containing the "bases of arrangement approved by the Governments of Great Britain and Germany in relation to Samoa, signed by the Marquis of Salisbury and Baron von Plessen, April 23. I887", (Memorandum by $\mathrm{M}^{\mathrm{r}}$ Cockerell $\mathrm{N}^{\mathrm{O}}$ I7 Page 7, Confidential print February i889: Further Correspondence respecting the Navigators' Islands, Part III.)

Lord Salisbury's despatch of the $30^{\text {th }}$ of April I887, transmitting these bases to Sir Lionel West, set forth the views, which Her Majesty's Government then held.

Baron von Marschall's tone was conciliatory and he was at special pains to say that the German Government looked upon the better feeling which had sprung up between Great Britain and Russia only as a further guarantee or European peace, and he said that personally he did not share the view which was entertained in some quarters that it would induce Russia to bring forward the question of the opening of the Dardanelles, or the further apprehension that this question might be dealt with separately by England, France and Russia to the exclusion of other Powers.

\footnotetext{
${ }^{392}$ Rhodes, prime minister of the Cape Colony, had attempted to buy Delagoa Bay (Maputo Bay) - the terminus of the railway line from Pretoria - from Portugal.

${ }^{393}$ Marschall was referring to the failed Samoa conference at Washington in 1887.

${ }^{394}$ On 3 December 1894 Grover Cleveland, in his State of the Union address, signalled American intentions to withdraw from the condominium governing the Samoan Islands (composed of Germany, the United States, and Great Britain) which had been created by the Treaty of Berlin in I889.
} 


\section{FO 64/1357: Edward B. Malet to Earl of Kimberley, Africa, No 1o, I February 1895}

[Received 4 February by bag. For: The Queen / Lord Rosebery / Lord Ripon; Colonial Office - confidential; Print (South Zambezi); See No. II Africa, 22 February; Approve language, 4 February; [approved] ig February]

Conversation with Marschall on Transvaal question; Rhode's designs on Transvaal might have severe consequences for Anglo-German relations

On my going to see Baron von Marschall this morning, His Excellency opened the conversation by reverting to what had passed between us regarding the Transvaal, as recorded in my Despatch $\mathrm{N}^{\mathrm{O}}$ $6^{\mathrm{A}}$ Africa of the $26^{\text {th }}$ ultimo, ${ }^{395}$ and said that $\mathrm{M}^{\mathrm{r}}$ Rhodes had recently amply justified the apprehensions of the Imperial Government as to his intentions with regard to the Republic. ${ }^{396} \mathrm{He}$ had openly announced his intention to take it. I said I thought His Excellency must be in error: that I had carefully read what $\mathbf{M}^{\mathrm{r}}$ Rhodes had said and I had seen no statement of that kind. Baron von Marschall spoke in a very animated manner and with great anger at $\mathrm{M}^{\mathrm{r}}$ Rhodes' interview with the "Kreuz Zeitung" correspondent, 397 and I did not see any way to contesting that what he was reported to have said was in the highest degree offensive to Germany. His Excellency said that it was outrageous that the Prime Minister of a Colony ${ }^{398}$ should speak in that way of a friendly nation, and that it rendered the task of endeavouring to moderate the language of the Colonial party in Germany hopeless. Baron von Marschall said that I had spoken of the coquetry of Germany with the Transvaal; what was this in comparison with the overtly aggressive tone of $\mathrm{M}^{\mathrm{r}}$ Rhodes towards that country.

By this time the reports of $\mathrm{M}^{\mathrm{r}}$ Rhodes' interview and of $\mathrm{D}^{\mathrm{r}}$ Jameson's speech, ${ }^{399}$ which His Excellency had sent for, had arrived, and I was at pains to point out to His Excellency that neither the one nor the other contained language which could be construed to a

\footnotetext{
${ }^{395}$ In their conversation of 26 January Malet and Marschall discussed the implications of the German 'tendency to coquetry with the Government' of the South African Republic (Transvaal) and Germany's plan to send a naval ship to Delagoa Bay for the opening of the railway line to the Transvaal. From Marschall's point view this was a 'mere act of courtesy'; however, it could not, in Malet's opinion, 'fail to raise hopes in the mind of President Krüger which might do harm'.

${ }^{396}$ Marschall was referring to Rhodes's undisguised ambition to incorporate the South African Republic into the Cape Colony.

397 The account of the interview was published in the Neue Preußische Zeitung (Kreuzzeitung) of 27 January 1895 . The correspondent's name is not traceable.

${ }^{39^{8}}$ Cape Colony.

${ }^{399}$ Speech at the Imperial Institute, London, on 28 January I878.
} 
menace. Both only dealt with the natural progression of events. I said that it seemed to me that no objection could be taken to the remarks regarding the progressive increase of the English population and its eventual result.

Baron von Marschall held that it distinctly pointed to an eventual alteration of the status quo which both Her Majesty's Government and the German Government proposed to maintain, and he said that the effect of these utterances on public feeling in Germany was intense.

I said that my great fear was that it would become so also in England if the German Government continued to allow the Transvaal Government to rely upon it as aiding it against England; that I was glad that His Excellency had opened the question with me again, because it so happened that Your Lordship had written to me privately on the subject and that in order that he might know exactly what you felt, I would read it to him. I then read to him Your Lordship's private letter of the $30^{\text {th }}$ ultimo. ${ }^{400}$

I will not say that the reading of the letter moderated His Excellency's vivacity. He strongly asserted that nothing had passed between Germany and the Transvaal which should give us umbrage; that he knew the wording of our Treaty and that there could be no question of an Alliance. ${ }^{401}$

Here I remarked that there were various forms of Alliance; that for instance there was no Treaty Alliance between Great Britain and Italy, but that Italy doubtless hoped that the strong friendship which existed between the two countries would be of valuable assistance to her in case she were attacked. Were we to announce suddenly that we would under no circumstances raise a finger to save her from aggression, her position would be greatly changed, and this I said was what I feared in regard to the Transvaal; the ostentatious friendship of Germany might lead to further demonstrations of hostility towards us, and might precipitate the very state of affairs which Germany desired to ward off - "After all", I said, "surely the commerce of the Transvaal is not so serious an interest to Germany as the continued existence of the present European equilibrium."

\footnotetext{
${ }^{400}$ In his private letter of 30 January Kimberley referred to President Kruger's toast to the Kaiser on the occasion of Wilhelm II's birthday (on 27 January 1895) and addressed the ambivalent German position towards the South African Republic.

${ }^{401}$ Article 4 of the London Convention of 27 February I884 stipulated that the 'South African Republic will conclude no treaty or engagement with any State or nation other than the Orange Free State ... until the same has been approved by Her Majesty the Queen.'
} 
Baron von Marschall asked me in what way the Transvaal has ever shown hostility to us. I said that I could but consider as a feather in the air showing which way the wind blew, that the Transvaal Minister accredited to this Court, Herr von Blokland, had never got introduced to me. How did His Excellency account for this want of common courtesy? Baron von Marschall said it merely showed that he was a "Monsieur mal élevé". ${ }^{402}$

The discussion had now drifted into quieter waters. I readily acknowledged that His Excellency had a right to be indignant at the way in which $\mathrm{M}^{\mathrm{r}}$ Rhodes had spoken about Germany and her colonies, but I said that, as to the progress of events in South Africa tending towards a Commercial $\mathrm{Union}^{403}$ at some future time, there was no means of hindering it. The 50,00o Englishmen in the Transvaal would probably be IOo,ooo within twenty years: could it be otherwise than that they would impress their views in the end on the numerically insignificant minority of Boers. His Excellency said that Commercial Union means the annihilation of German trade with the Transvaal. It would be exactly the alteration of the status quo which was against Germany's interest. It was juggling with words to express an intention to maintain the status quo and at the same time to desire a Commercial Union. I said that I was extremely sorry that there should be such warm feeling in regard to the Transvaal on either side and that I regarded the question as a "point noir". ${ }^{404}$ His Excellency said - "prevent $\mathrm{M}^{\mathrm{r}}$ Rhodes from speaking about Germany. The two Governments can get on amiably on the basis of the status quo; but if $\mathrm{M}^{\mathrm{r}}$ Rhodes thunders in public about never relinquishing Walfisch $\mathrm{Bay},{ }^{405}$ for which we never asked, and twits us with maladministration and the poverty of our possessions, how is it possible to expect things to go on smoothly?"

The discussion which had begun stormily ended quietly with the mutual expression of the general desire which animates both Governments to work in harmony.

There is no doubt that $\mathrm{M}^{\mathrm{r}}$ Rhodes' remarks were intolerably galling and that, if he continues to hold language of this nature, the desire of the two Governments to keep up friendly relations, so far as the Press and public feeling are concerned, will be frustrated.

\footnotetext{
$4^{\mathrm{o} 2}$ French: 'badly brought up gentleman'.

${ }^{403}$ Malet was referring Jameson's idea of a future 'commercial union, amalgamation, or federation of all South African States' as brought forward in the speech of 28 January.

${ }^{404}$ French: 'black spot'.

${ }^{405}$ Walvis Bay was an enclave in German South West Africa which had been in British hands since I878, before being formally annexed to the Cape Colony in I884.
} 


\section{FO 64/1350: Martin Gosselin to Earl of Kimberley, No 74, Berlin, 29 March 1895}

[Received I April by bag. For: The Queen / Prince of Wales / Lord Rosebery; $\mathrm{K}$ [imberley]]

Political implications of a rejected bill authorizing the Reichstag president to congratulate Bismarck on his $80^{\text {th }}$ birthday

In my Despatch No. 69 of the 23rd instant, I had the honour to report to Your Lordship the rejection by the Reichstag ${ }^{406}$ of the proposal that the President should be empowered to convey to Prince Bismarck the official congratulations of the House on the occasion of the 8oth anniversary of his birthday.

The Emperor, on hearing of the result of the vote, lost no time in telegraphing to the Prince that the decision of the Reichstag was diametrically opposed to the sentiments of all German Princes and their peoples; and I am informed that, had it not been for the advice tendered by Prince Hohenlohe, the telegram, significant as it is of the position of parliamentary government in this country, would have been yet more strongly worded.

The intended parliamentary demonstration in favour of the old Chancellor, which undoubtedly ought to have been treated as an entirely non-political question, has been seriously mismanaged. The Centre ${ }^{407}$ would probably have acquiesced in, or at least have abstained from opposing a mere message of congratulation, had not the Conservative Press done their best for the last fortnight to capture the demonstration for their own agrarian purposes, and shut the door to any compromise by loudly proclaiming the Radical and Socialist Parties as "hostile to the Empire," for opposing the repressive legislation which is now being considered by the Reichstag. ${ }^{408}$

The rumour that the Emperor intends to dissolve the Reichstag is discredited in all well-informed circles here; if the elections could take place at once, when the country is under the impression of the recent vote, it is possible that the Conservatives and National Liberals might improve their position; but in view of the work which still remains to

\footnotetext{
${ }^{406}$ On 23 March I895. The proposal was made by the president of the Reichstag, Albert von Levetzow. Bismarck's birthday was on I April.

${ }^{407}$ Zentrumspartei (Catholics).

${ }^{408}$ Gosselin is referring to the 'subversion bill' (Umsturzvorlage) which had been introduced in the Reichstag on 5 December I894. See n. 38I in this section.
} 
be done, before the present session can be closed, two months must elapse before the new elections could be held, and long before the expiration of that period, the Nation would have forgotten the unfortunate incident of last Saturday, which after all was not technically a defeat of the Government, and the electorate would in all probability be under the influence of other and more dangerous cries.

In consequence of the rejection of the proposal, not only the President, Dr. von Levetzow, but Dr. Bürklin, the second Vice President, belonging to the National Liberal Party, both resigned their offices ${ }^{409}$ and the Reichstag met the day before yesterday to elect two of their members to the vacancies.

Baron von Buol-Berenberg, formerly the Senior Vice President, belonging to the Centre Party, was elected President by i83 out of 29I votes; the first Vice Presidency falling to Herr Schmidt, the Radical Member for Elberfeld, and the second to Herr Spahn, the Catholic Member for Cologne.

The Socialists, who number forty-five in the present Reichstag, and, after the Centre, formed the most numerous group in the heterogeneous majority of the $23 \mathrm{rd}$, declined to exercise their right to be represented on the Presidency, on the ground that their freedom of action would be fettered, if one of their members were elected Vice President.

The Conservative and National Liberal Parties, who formed the minority on Saturday, handed in blank voting papers as a protest against the action of the majority.

The new President has gained a long experience of his duties in the Chair as Senior Vice President, and made favourable impression by the readiness with which he stilled the storm which broke out, when the result of the Bismarck vote was announced; unfortunately he is somewhat deaf.

In the interest of the smooth working of the Parliamentary Machine, it is none the less to be regretted, that the new President owes his election to the support of the Socialists, and that neither the Conservatives nor the National Liberals, - the so-called Cartell Parties, ${ }^{40}$ - are responsible for the election of the Speaker or of either of his Substitutes.

\footnotetext{
${ }^{409}$ On 23 March I895.

$4^{\text {IO }}$ See n. 208 in this section.
} 


\section{FO 64/1350: Martin Gosselin to Earl of Kimberley, No 76, Berlin, 3o March I895}

[Received I April by bag. For: The Queen / Prince of Wales / Lord Rosebery; $\mathrm{K}$ [imberley]]

Bismarck's 8oth birthday; Reichstag and Prussian Landtag deputations visit Friedrichsruh; Bismarck's speech; emperor's congratulatory visit and bestowal of honours

In my Despatch No 74 of the 29 instant, I have related the untoward incident which occurred in the Reichstag on the 23 instant, with regard to the refusal of the House to authorize the President to convey to Prince Bismarck their congratulations on his 8oth birthday. ${ }^{41}$

As a counter-demonstration to this vote, the members of the upper and lower Houses of the Prussian Diet and the Conservative and National Liberal members of the Reichstag, to the number in all, of some four hundred, went to Friedrichsruh on the 25 instant to offer to the old Chancellor their best wishes on his birthday, Herr von Levetzow, the ex-president of the Reichstag, in his address taking an opportunity of expressing his personal regret that he was enabled to speak in the name of only some 150 members of the House.

Prince Bismarck, in his reply, urged his hearers to follow, not a local Brandenburg, nor even a Royal Prussian, but an Imperial German Policy; a piece of advice, which in view of the known Agrarian sympathies of many of his hearers, was the more remarkable; and he further urged the legislators present to hold fast to their loyalty to the Sovereign Houses of Germany.

With a very pardonable allusion to the Reichstag Vote, His Highness said, "I can truly say that the Confederated States, their Governments and Dynasties are better people ("leute") than the Political factions. The latter place above the national interests every political ill-humour, every rivalry, every clean and unclean emulation; whereas our reigning families place national interests to the fore. Compare and weigh the bearing of our dynasties and our political factions, and learn a lesson therefrom."

Prince Bismarck repeated the same idea on the following day in his speech to the Emperor. "Outside of attachment to the dynasties, there is no salvation in Germany."

His Majesty, who was fully alive to the bad effect which the refusal of the Reichstag to join in the national celebration of Prince Bismarck's birthday would make throughout Germany, determined to do all that was possible to enhance the effect of His visit to

\footnotetext{
${ }^{41 \mathrm{I}}$ See preceding dispatch.
} 
Friedrichsruh on the 26 instant, being accompanied by the Crown Prince, ${ }^{412}$ the Minister of War ${ }^{413}$ and the heads of the military, naval and civil Cabinets. ${ }^{414}$

In a military country such as Germany the significance of the attention paid by His Majesty to the ex-Chancellor, in holding a review of troops in his honour, - an honour which, as far as I am aware, has never yet been paid by a Sovereign to a subject, - is brought home to the whole nation; and the fact that the arms of Alsace-Lorraine were engraved on the golden sword of honour presented to the Prince by the Emperor in the presence of the troops, and still more the words in which the Emperor alluded to the part played by him in the events of $\mathrm{I} 870-7 \mathrm{I}$, will strike not only a responsive chord throughout the Fatherland, but will, it may be surmised, make a serious impression beyond the Vosges.

I am informed that the Prince was quite overcome by His Majesty's gracious words, and stooping down, kissed the Emperor's hand.

On the 27th, Prince Bismarck received a visit from Prince Henry of Prussia, the Grand Duke of Baden and Prince Hohenlohe, the present Chancellor, who conveyed to his illustrious predecessor the congratulations of the Bundesrath and the Prussian Ministry.

The chief political greetings are now over, but a whole series of deputations and excursionists from all parts of Germany intend to visit Friedrichsruh during the course of the next week.

Prince Bismarck is said to be none the worse for the fatigues naturally incident on this long series of receptions.

\section{FO 64/1350: Edward B. Malet to Earl of Kimberley, No I5I, Berlin, 24 June 1895}

[Received 30 June. For: The Queen / Admiralty, 8 July; S[alisbury]]

\section{Celebratory opening of the North Sea and Baltic Canal at Hamburg and Kiel}

I have the honour to inform Your Lordship that the official fêtes for the opening of the North Sea and Baltic Canal ${ }^{45}$ came to an end on Saturday the $22^{\text {nd }}$ instant.

The number of ships representing the various maritime Powers of the world which were together on the occasion in Kiel harbour

${ }^{42}$ Wilhelm.

${ }^{413}$ Walther Bronsart von Schellendorff.

${ }^{414}$ Wilhelm von Hahnke, Gustav von Senden-Bibran, and Hermann von Lucanus.

${ }^{415}$ The Kiel Canal (Kaiser Wilhelm-Kanal) linked Brunsbüttel and Kiel. 
surpassed, I believe, any international gathering of the kind which has ever taken place. Vessels of the following nations were present:

United States of America,

Denmark.

Great Britain

Germany..........................

France.

Italy....

Holland

Austria.

Portugal.

Roumania

Russia....

IO "

Sweden and Norway.............

Spain

Turkey

in all, one hundred and one ships belonging to the various navies of I3 nations. The nations not represented were not invited.

The Banquet given by the Emperor on the $2 \mathrm{I}^{\text {st }}$ instant numbered I,I6o guests.

The speeches made by His Majesty at Hamburg and Kiel ${ }^{4{ }^{46}}$ were chiefly remarkable for the manner in which His Majesty dwelt upon the blessings of peace and his desire to maintain it.

The whole of the Reichstag was invited and was present, with the exception of the socialists. A large number of the deputies probably saw the sea for the first time, and it no doubt entered into the calculation of the Government that the impressive sight would render them more pliant in future in regard to Naval estimates.

Some comment was excited by the refusal of the French officers to attend the Banquet at Hamburg, but they came to the ball and the Banquet at Kiel. The French sailors did not go on shore. The Emperor spoke to the two French Admirals ${ }^{417}$ for some time after the Banquet, and the French Ambassador ${ }^{48}$ told me that they were much impressed by His Majesty's extraordinary mastery of the details of naval matters and his power of expressing the minutest technical points in correct French.

\footnotetext{
${ }^{416}$ On I9 and 2I June I895.

${ }^{417}$ Only one French admiral, Rear Admiral Ménard, was present.

${ }^{4}{ }^{18}$ Jules Herbette.
} 
A newspaper correspondent informed me that the only official injunction which had been issued by the bureau of the Press at the German Foreign Office was that if any disagreeable incident should unfortunately arise in connection with the presence of the French it was not to be reported.

The arrangements for the comfort and convenience of the guests were admirable. As an instance of how far these were carried, it is worth mentioning that the telephone was laid to all the principal ships, so that it was possible for those on board to communicate with each other as well as with the principal towns of Germany.

The Diplomatic Corps was treated with the greatest hospitality and attention, and at the last repast on board the "Augusta Victoria" I rose at the request of my colleagues and proposed the health of Baron Marschall, Minister for Foreign Affairs, and expressed our grateful thanks for the attention which we had received.

\section{FO 64/1359: Martin Gosselin to Marquess of Salisbury, Africa, No 139, 29 October 1895}

[Received 3r October by post. For: Print (South Zambezi) / Mr Balfour / Duke of Devonshire / Colonial Office; S[alisbury] $]^{419}$

Marschall's response to Amatongaland protectorate; resumption of conflict in South-Eastern Africa; German activities in Southern Africa seen as serious threat to Anglo-German relations

The answer of Baron von Marschall to the notification announcing the Amatongaland protectorate (copy of which is enclosed in my immediately preceding Despatch of today's date $)^{420}$ is but the latest of a whole series of steps taken by the German Government to show their sympathy with the Boers and their anxiety to increase the political and commercial influence of this country in the South African Republic and in the Portuguese province of Lorenzo Marques.

\footnotetext{
${ }^{419}$ Note on docket: 'Thank for interesting resumé', C.Ll.H [Clement Lloyd Hill]; 'The various communications between Lord Kimberley and Count Hatzfeldt might be added. On one point Mr Gosselin is mistaken. The arrangement between the steamship companies allows the British Companies to run to Lorenzo Marques but not north of it. Mr Donald Curne tells me that both his line and the Union line will continue to trade in Delagoa Bay. This might be explained.' H.P.A. [Henry Percy Anderson], 3플 October. 'Done', II November; S[alisbury].

${ }^{420}$ British sovereignty over Amatongaland (Tongaland) was proclaimed on 23 April and publicly announced on in June. Marschall's answer is dated 25 October and contained, apart from the customary acknowledgements, the observation that the South African Republic had protested against this annexation of territories.
} 
It may be of interest to recapitulate the various incidents of this campaign in South East Africa, the first of which dates from a little more than a year ago.

(I.) When the Kaffirs were threatening Lorenzo Marques in October of last year, ${ }^{21}$ the German men-of-war "See-adler" and "Condor" were despatched to Delagoa Bay, to safeguard, as Baron von Marschall stated, "the large German interests involved both on the coast and in the Transvaal." [Note in margin: "See my Desp I2I Africa of Oct 19. I894']

So serious did the German Government then consider the situation that, as Baron von Marschall explained to the Reichstag, ${ }^{422}$ when the naval estimates were being discussed, [Note in margin: 'See my Desp. 46 Africa of April 2. I895'] the "See-adler" was hurriedly despatched from Kilwa to Delagoa Bay, though at the time Kilwa itself was being threatened by the insurgent Arabs; while the "Condor" was ordered out to the same destination all the way from Kiel. ${ }^{423}$ Simultaneously with the despatch of the two German ships to Delagoa Bay, Jonkherr Beelaerts von Blokland, the Transvaal Minister accredited here and to the Portuguese and Netherlands Governments, arrived in Berlin.

(2.) The next incident bearing on Germany's relations with the Transvaal was Mr Rhodes' interview with the "Kreuz Zeitung's" London correspondent ${ }^{24}$ (reported in the "Times" of the $28^{\text {th }}$ of January last) which created quite a storm of indignation in the German Press, and was the subject of somewhat acrimonious observations on Baron von Marschall's part, as reported in Sir E. Malet's Despatch No Io Africa of the ist February last. ${ }^{425}$

(3.) [Note in margin: 'See Sir E. Malet's 26 Africa of March I2. I895'] In the following month the German Government replaced the trading Consul Herr W. Joost, who had hitherto represented German interests at Delagoa Bay, by a "consul de carrière", and appointed Count Markus Pfeil to the post, ${ }^{426}$ a step which was greeted with undisguised satisfaction in Colonial circles, [Note in margin: 'My

\footnotetext{
${ }^{421}$ The revolts and attempted attacks by the population, here derogatively called 'Kaffirs', on Lourenço Marques (Maputo), a Portuguese port in Delagoa Bay, stemmed from resistance to Portuguese taxation and interference in a succession dispute.

${ }^{422}$ On I March 1895.

${ }^{423}$ The cruiser Seeadler was ordered from Kilwa on I5 October I894; Condor left Germany on 16 October and arrived at Lourenço Marques on $1_{5}$ December.

${ }^{424}$ Walter Freiherr von Bissing.

${ }^{425}$ See pp. I7 ${ }^{-}-\mathrm{I} 73$.

${ }^{426}$ Pfeil was appointed commissary consul at Lourenço Marques on 29 January I895.
} 
Desp No 33 Africa of March i6. I895'] as tending to mark the Empire's independent policy in South Africa inaugurated last Autumn, and as a means towards the maintenance of the balance of Power in that part of Africa.

(4) [Note in margin: 'My Desp 68 Africa of June Io. I895] At the annual general meeting of the German Colonial Society, held at Cassel under the Presidency of Duke John Albert of MecklenburgSchwerin, on the 6th of June, a resolution was adopted in favour of "all measures calculated to promote friendly relations with the Transvaal people and to strengthen their independence", and it was currently reported at the time that during the discussion of this resolution the hope was expressed that the German Government would refuse to recognize the annexation of the three Amatongaland States.

(5) [Note in margin: "Sir E. Malet $\mathrm{N}^{\mathrm{o}} 89$ Africa of July 20.1895] The return of the "Condor" to Delagoa $\mathrm{Bay}^{427}$ and the visit of the Germans to Pretoria on the occasion of the opening of the Delagoa-Pretoria Railway. ${ }^{428}$

(6) The telegram ${ }^{429}$ of congratulation addressed by the Emperor William to President Kruger on the occasion of his visit to the "Condor", in which the opening of the railway is alluded to, as a "means of drawing the bonds which connect the two countries".

(7) Lastly, the Agreement of April last, between the Portuguese Government and the German East Africa Line, ${ }^{430}$ whereby the mailpacket service between Portugal and her possessions on the South East Coast of Africa passed from British into German hands, [Note in margin: 'Sir H. Macdonell $\mathrm{N}^{\mathrm{O}}$ 4I Africa May 20. I895. Sir E. Malet $\mathrm{N}^{\text {os }} 86$ \& II 6 Africa of $12^{\text {th }}$ July \& 30 Oct. I895.'] an arrangement, which must inevitably strengthen Germany's position and prejudice English trade on that portion of the African Littoral.

All these several incidents, capped as they are by Baron von Marschall's reply with regard to Amatongaland, are symptoms of an intention on the part of the German Government to adopt a forward, not to say aggressive line of action with regard to the

\footnotetext{
${ }^{427}$ On 27 June I895.

$4^{28}$ The Delagoa-Pretoria Railway was opened at Pretoria on 8 and 9July. A deputation of German naval officers from the Condor visited Pretoria on 8 July I895.

${ }^{429}$ Dated I7 July I895; Kruger visited the Condor on the same day.

$4^{\circ}$ Convention of Io April I895.
} 
Transvaal; and I would venture to point out that none of the incidents alluded to above were the handiwork of Colonial Chauvinists and excited explorers, like Dr. Peters of yesterday or Dr. Gruner of today, who, full of their achievements, enjoy nothing so much as to put forward claims to the regions of their exploits.

Nor, as far as I can discover, are they to be attributed to the advice of the Colonial Department, which, I believe, has nothing whatever to say to German relations either with the Transvaal or the Portuguese Colonies.

The policy of this country in the Transvaal would seem to be inspired from the highest source; and, if this surmise is correct, it undoubtedly demands all the closer attention on the part of Her Majesty's Government.

As illustrating the rapidity with which the idea of Germany's interests in the Transvaal is spreading, I may mention that in an article published by Dr. Georg Schweinfurth, the noted African traveller, in the "Berliner Rundschau" for last July, entitled the "New Birth of Egypt", ${ }^{43}$ which breathes throughout a very friendly spirit to the British occupation in Egypt, it is expressly laid down that Germany's price for a free hand for England on the Lower Nile is, amongst other things, "the Independence of our South African friends".

I am not, of course, aware whether it is the intention of Her Majesty's Government to enter into any negotiations for the settlement of the Colonial questions still outstanding with this Empire; but if any such idea should be entertained, I would venture to call attention to this new "dark spot", which threatens to become, unless taken in time, a danger to the good relations of the two countries, far otherwise serious than any possible disputes as to Togoland, Damaraland, Witu or even Samoa.

In conclusion, I would observe that all the incidents referred to above have taken place since Count von Caprivi's resignation, ${ }^{432}$ and that the present Chancellor ${ }^{433}$ is known to be personally in favour of a forward policy in all Colonial matters.

${ }^{43^{1}}$ 'Die Wiedergeburt Ägyptens im Lichte eines aufgeklärten Islam', Berliner Rundschau,

No 24, Io July I895.

${ }^{432}$ See n. 379 in this section.

${ }^{433}$ Chlodwig zu Hohenlohe-Schillingsfürst. 


\section{FO 64/1351: Martin Gosselin to Marquess of Salisbury, Secret, No 278, Berlin, 25 November 1895}

[Received 29 November by messenger. For: The Queen / Mr Balfour / Duke of Devonshire; S[alisbury]]

\section{Discussion with Prussian minister of war; rumours of possible alliance with Russia}

Some fortnight ago one of the best informed of my colleagues met the Minister of War, General Bronsart von Schellendorff, and the conversation turned on the question of the possible alliances of this country.

General Bronsart said that, come what might, it was essential for this country to do everything possible to reestablish a good understanding with Russia.

Why, asked my informant: would it not be well, before speaking so positively, to think of England? Every penny advanced to Russia, every concession made to her in the near or the far East, weakens pro tanto ${ }^{434}$ the influence of England, who, next to Austria, is after all Germany's nearest blood-relation.

The War Minister answered that it was all very well to talk of an English Alliance, but even if England had the will, she hadn't the men to make it worth while for this country to sacrifice for her good will the possibility of a Russian Alliance.

At Sea she is a great Power, - "too great a Power, I had almost said", - but she would be of little use to Germany in a European war. Russia, England, France, all Europe is looking to the East, while, as for Austria, her axis has already been moved from Vienna to Pesth, and in this Eastward movement, our own Eastern neighbour will assuredly play a great part - so that Germany, whatever might be wished, cannot afford to neglect Russia for the platonic good will of Great Britain. It is hoped, too, said His Excellency, that the marriage of the Russian Emperor with a German Princess ${ }^{435}$ will tend to draw nearer the relations of the two Empires.

Besides this, England cannot be counted: she has treated us in the East African business in a quite scandalous manner; ("Man hat uns in dieser Ost-Afrikanischen Angelegenheit ganz miserabel behandelt;") and is always opposing any extension of German influence in the Colonies.

Well, said the diplomatist, I know little of Africa, but surely there should be room for all, and most of all for England and Germany,

${ }^{434}$ Latin: 'to that extent'.

${ }^{435}$ Nicholas married Alix of Hesse (Alexandra Feodorovna) on 26 November I894. 
who are the two great civilizing (Kultur) powers of the day in that part of the world.

General Bronsart expressed the wish that this happy state of things could be realized; it might in the future, but certainly had not been so yet.

As General Bronsart von Schellendorff is one of the most important members of the Prussian Cabinet, and is perhaps more frequently in contact with the Emperor than any of his colleagues, I venture to record His Excellency's observations as related to me.

The Statement about East Africa is singular, and illustrates the height to which the feeling about Zanzibar is rising in this country: the cession by Her Majesty's Government of Heligoland appears to be entirely forgotten by the German Colonial Party: people look at the Map of German East Africa, and see the adjacent islands of Zanzibar and Pemba marked with another colour, and straightway fly to the conclusion that England has robbed the Fatherland of her fairest flowers in that region. ${ }^{436}$

There can be little doubt, that His Excellency's remarks as to the urgency of a good understanding with Russia reflect very faithfully the views of the Emperor.

To take only the last month, His Majesty has given within that time three proofs of his anxiety to be well with his Russian Neighbour: -

I - The despatch to $S^{t}$ Petersburg by an Aide de Camp, ${ }^{437}$ of the famous Allegorical picture, designed by His Majesty, representing the European crusade against Buddha, in which (as a glance at the enclosed print will show $)^{438}$ the wish for intimate relations with Russia is clearly indicated by the grouping of the figures.

2 - The presence of the whole Court at the Russian Embassy Chapel at the Requiem sung on the anniversary of the late Emperor Alexander's death. ${ }^{439}$

\footnotetext{
${ }^{43}{ }^{6}$ On I July 1895 the territory that had been claimed by the British East Africa Company in 1888 was placed under the protectorate of Great Britain (East Africa Protectorate). Zanzibar and Pemba had already become a British protectorate, following the Anglo-German agreement of I July i89o, known as the Heligoland-Zanzibar Treaty, which amongst other things, regulated the frontiers of East Africa. In return for the recognition of British interests in the Zanzibar region Britain ceded the islands of Heligoland to Germany.

${ }^{437}$ Helmuth von Moltke; the picture was presented to the tsar on 30 September.

${ }^{43}{ }^{8}$ Enclosure: cutting of image entitled Völker Europas waht eure heiligsten Güter (Peoples of Europe, Protect Your Most Sacred Possessions), designed by Kaiser Wilhelm II; lithograph by Hermann Knackfuss, I895.

${ }^{439}$ On I November I895.
} 
3 - The invitation to the Grand Duke Vladimir to join in a shooting party last week near Potsdam.

These incidents, which are merely the latest of a whole series of similar attentions on the part of His Majesty, show clearly enough the importance which is attached here to a good understanding with Russia.

\section{FO 64/135I: Martin Gosselin to Marquess of Salisbury, No 296, Berlin, 7 December 1895}

[Received 9 December by bag. For: The Queen / Prince of Wales / Mr Balfour; S [alisbury]]

Resignation of Prussian interior minister; purported reasons include repression of socialists, bad relations with other ministers, Agrarian Party opposition

A ministerial crisis has during the last week declared itself in the Prussian Cabinet, and it is reported positively that Herr von Köller, Prussian Minister of the Interior, has tendered his resignation to His Majesty. ${ }^{40}$

Herr von Köller, who came into Office simultaneously with the present Chancellor ${ }^{4+1}$ in November of last year, has not been a successful Minister; his manner in the Reichstag has been anything but conciliatory, and the failure of the Government to pass the anti-Socialist Bills last Session ${ }^{44^{2}}$ is generally attributed as greatly due to His Excellency's want of tact and Parliamentary experience.

During the last two months severely repressive measures have been taken against the Socialist leaders. The chief socialist committees in the Capital have been dissolved; ${ }^{443}$ private residences have been searched by the Police; the editors of Newspaper Articles have been prosecuted; and the policy of repression culminated a short time ago in the action taken by Herr von Köller against Professor Delbrück, the Editor of the "Preussische Jahrbücher", Professor of History at the Berlin University, and formerly attached to the Household of the Emperor Frederick, when Crown Prince. ${ }^{444}$

\footnotetext{
${ }^{44^{\circ}}$ Köller handed in his resignation on 2 December I895; he was dismissed on 8 December.

${ }^{44 \mathrm{I}}$ Chlodwig zu Hohenlohe-Schillingsfürst.

${ }^{442}$ See n. $38 \mathrm{I}$ in this section.

${ }^{443}$ On 29 November 1895 the Berlin police dissolved I social democratic associations (Vereine), including the executive committee of the Social Democratic Party.

${ }^{444}$ Delbrück, in an article entitled'Politische Korrespondenz', dated 20 September I895, which appeared in the October issue of Preußische Fahrbücher, termed the measures against
} 
It was subsequently announced that the proceedings against the Professor for insulting the Police had been quashed, ${ }^{45}$ on the ground that he had assured the Minister of the Interior that he had no intention of inciting the Public against the guardians of public order; but the mistake has none the less damaged the position of the headstrong Minister.

It is also asserted that Herr von Köller had last week a violent dispute with the Minister of War, General Bronsart von Schellendorff, on the subject of the Army Discipline Bill, which may perhaps be the immediate cause of the Ministerial Crisis. ${ }^{46}$

I asked Baron von Marschall yesterday whether it was true that Herr von Köller had resigned, and, if so, who would be his probable successor at the Home Office.

Baron von Marschall replied that if he had not actually resigned the seals of Office, he was "un Ministre démissionaire", ${ }^{47}$ but that nothing would be known as to His Excellency's successor, until His Majesty's return from Hanover this evening.

In reply to my enquiry whether the Crisis would involve, any further changes in the Prussian Cabinet, His Excellency said that he really could not say; "now that Count Caprivi is no longer here, all the force of the agrarian attack will doubtless be levied at me, and I expect to have many a scene in the coming Session of the Reichstag".

As illustrating the length to which the Agrarian Party are prepared to go in opposing the Imperial Government, I may mention that the Agrarian League have - it is stated - addressed a letter ${ }^{44^{3}}$ in the following terms to the Imperial Secretaries of State for the Home and Foreign Departments (Herr von Boetticher and Baron von Marschall): -

"You have never ceased to fight us. You will therefore be considered and treated by us as enemies".

If this is true it would seem to indicate that the policy of concentration urged on the parties of order by His Majesty has not yet found much favour amongst those who have hitherto been regarded as the most loyal supporters of the Throne.

Social Democrats 'Thorheiten der Polizei' (the foolishness of the police). At Köller's instigation he was charged with defamation on 2 November.

${ }^{445}$ On 30 November 1895.

${ }^{446}$ Köller was the only Prussian minister who opposed the reform of military criminal procedure, in particular the introduction of public trials. The dispute culminated when Bronsart von Schellendorf, in the sittings of the war ministry of ${ }^{3} 3$ and 18 November, accused Köller of indiscretions and suspected him of leaking internal matters to the press.

${ }^{447}$ French: 'an outgoing minister'.

${ }^{44^{8}}$ Bund der Landwirte. Details of the letter could not be established. 


\section{FO 64/1359: Frank C. Lascelles to Marquess of Salisbury, Africa, Confidential, No r66, I3 December 1895}

[Received i6 December by bag. Where is enclosure?; For: Colonial Office; 'Herr Vohsen used much the same language as Dr Sieveking when over here in the summer, but it did not prevent the support of the Grüner and Togo claims.' C.Ll.H [Clement Lloyd Hill]; S[alisbury]]

\section{Differing approaches to colonial administration of England and Germany}

I have the honour to enclose a confidential memorandum by $\mathbf{M}^{\mathrm{r}}$ Spring-Rice, $2^{\text {nd }}$ Secretary of Her Majesty's Embassy, recording a conversation he recently had with Doctor Sieveking, the President of the Hanseatic Supreme Court at Hamburg on Anglo-German Colonial Matters. ${ }^{49}$

Hamburg is the great centre of the Colonial trade of this country, and the opinion of so competent an authority as the President of the Hanseatic Court on the Colonial relations of the two Empires may be of interest to Your Lordship. As illustrating the different systems of administration in vogue in the British and German possessions in Africa, I may mention that $\mathrm{M}^{\mathrm{r}}$ Gosselin was told only today by an eye-witness that some years ago, Major v. Wissmann during his first Governorship of German East Africa met one of the Directors of the British East Africa Company at dinner at the British Agency at Zanzibar.

After dinner, the Conversation turned on the different systems adopted in the neighbouring Protectorates, and the Major, speaking perhaps more openly than he would have done before the banquet, said,

"My good friend, what is the use of our discussing these matters? We adopt an entirely different method of rule than that which prevails with you. If a nation chief comes to you with a grievance, you give him a length of cloth, and try to put him in a good temper, whereas if a chieftain comes to me with a complaint, he is simply shot."

Allowing for a large amount of after dinner exaggeration in the above remark, it shows how little the then Governor, (who has just returned in the same capacity to Dar-es-Salaàm) had tried to understand the natives entrusted to his charge, and may explain many of the difficulties with which he had to contend.

\footnotetext{
${ }^{449}$ Enclosure: confidential memorandum by Cecil Spring-Rice recording his conversation with Dr Sieveking, undated.
} 


\section{FO 64/1386: Frank C. Lascelles to Marquess of Salisbury, Africa, Confidential, No I, 2 January 1896}

[Received 6 January by bag. For: The Queen / Cabinet, 7 January; Colonial Office (confidential); Print; S[alisbury]]

At the New Year's reception at Court yesterday I had an opportunity of a short conversation with Baron von Marschall who told me that he had received very bad news from the Transvaal. A band of 800 men belonging to the Chartered Company had crossed into the Transvaal and it was evident that a conflict was imminent even if it had not already taken place. Our conversation was interrupted by the entry of the Emperor who after having spoken to the other Ambassadors addressed me with great cordiality and after expressing the extreme pleasure which the Queen's New Year's present had given him, began to talk about the events in the Transvaal. ${ }^{45^{\circ}}$

His Majesty characterized the armed force under $\mathrm{D}^{\mathrm{r}}$ Jameson as a band of filibusters who he hoped would all get shot as they deserved to be, and said that he was anxious to see what steps Her Majesty's Government intended to take. He could quite understand that this incident would cause embarrassment to Her Majesty's Government, who he hoped would send more ships to the Cape. His Majesty concluded by saying that his concern in this question was caused by the vast German Commercial Interests in that part of the world.

On my return from the Palace I found Your Lordship's Telegram $\mathrm{N}^{\mathrm{O}} 9$ Africa of which I at once took a paraphrase to Baron von Marschall. ${ }^{4{ }^{1}}$ His Excellency who was in a state of considerable excitement, said that he did not doubt $\mathrm{M}^{\mathrm{r}}$ Chamberlain's pacific intentions, but that the invasion of the Transvaal by an armed force of English soldiers constituted so grave a violation of Treaties and International Law that the German Ambassador in London had been instructed ${ }^{452}$ to ask Your Lordship what steps Her Majesty's Government intended to take in the matter. This armed attack on a Power with whom Her Majesty's Government were at peace was

\footnotetext{
$45^{\circ}$ The crossing into the Transvaal ('Jameson Raid') started on 29 December 1895 and ended on 2 January I896 when the invading force, under Jameson, the administrator general of the chartered company for Matabeleland, surrendered. It aimed to incite an uprising among the foreign (and especially British) residents of the South African Republic (Uitlanders) who, amongst other things, demanded citizenship and voting rights.

${ }^{45^{1}}$ The telegram, dated 3I December 1894, stated Chamberlain's intention 'to avert violence and restore tranquillity' in South Africa.

${ }^{45^{2}}$ Telegram of $3^{\text {I }}$ December from Marschall to Paul von Hatzfeldt.
} 
all the more unjustifiable because it took place at the very moment when the Transvaal Authorities were considering the concessions they could make to the Uitlander population. If the Chartered Company were to be permitted to attack a friendly state with impunity, there could be no security for Foreign Interests in South Africa, and they might even take it into their heads to attack the German possessions.

I called again this morning on Baron von Marschall who had received from Count Hatzfeldt a telegraphic account of his conversation with Your Lordship. ${ }^{453}$ His Excellency was calmer than he had been yesterday, but still took a very serious view of the matter. $\mathrm{He}$ doubted whether the orders of Her Majesty's Government to $\mathrm{D}^{\mathrm{r}}$ Jameson to retire could reach him in time to prevent a conflict, and he did not feel sure that they would be obeyed. His Excellency then referred to the tone of the English press which had become very unsatisfactory more especially the "Times" which said that England could not permit any foreign interference in the Transvaal. Such a statement could only apply to Germany and could not fail to increase the very great irritation which was now entertained against England. Germany could not admit that England had greater rights over the Transvaal than any other Power except in so far as the $4^{\text {th }}$ Article of the Convention of I884 ${ }^{454}$ provided that any Treaties which the South African Republic might make with other Powers would be submitted to Her Majesty's Government who had a right of objecting to them within a given period. In all other respects, His Excellency said Great Britain had recognized the South African Republic as an independent State. His Excellency again referred to the commercial interests of Germany and said that the railway ${ }^{455}$ from Pretoria to the Portuguese frontier had been built almost entirely with German capital. There was a feeling that the commercial interests of Germany had not been sufficiently protected by the Government and he could not conceal from me that the serious consequences which he apprehended from the conflict which now seemed imminent, would seriously impair the friendly relations, which, ever since he had been in office it had been his constant effort to maintain between our two Countries.

\footnotetext{
${ }^{453}$ Telegram of I January I896 on Hatzfeld's conversation with Salisbury of the same day.

${ }^{454}$ See n. 401 in this section.

${ }^{455}$ Delagoa Bay railway line, opened on 8 July I895.
} 


\section{FO 64/1386: Frank C. Lascelles to Marquess of Salisbury, Africa, Confidential, No 7, 6 January 1896}

[Received 8 January by post. For: Print (S. Zambezi) / Colonial Office / The Queen / Cabinet; S[alisbury] $]^{45^{6}}$

Marschall surprised by attitude of English press towards Kruger telegram; German position on South African independence

On the $4^{\text {th }}$ instant, I met Baron von Marschall at dinner and had the opportunity of conversing with him in the course of the evening.

His Excellency showed me a telegram which had been addressed to the Emperor by the Editor ${ }^{457}$ of the "Pall Mall Gazette", asking His Majesty's permission to publish a statement to the effect that His Majesty's telegram to President Kruger ${ }^{45^{8}}$ was not to be considered as an act of hostility towards Great Britain. Baron von Marschall said that no answer would be returned to this telegram and that that the view taken of His Majesty's language could be gathered from the utterances of the German Press.

His Excellency then went on to say that he was astonished at the attitude taken by the English Press and he was at a loss to understand how a congratulatory telegram addressed to the Chief of an independent State for having defeated an armed band which Her Majesty's Government had themselves declared to be outlaws could possibly be regarded as an act of hostility towards Great Britain. In His Excellency's opinion there could be no question as to the independence of the Transvaal which was fully secured by the convention of I884, subject only to the limitation contained in Article 4 of that convention. ${ }^{459}$

I replied that however much I might regret the tone adopted by the English Press, I must confess that it did not astonish me. I reminded His Excellency that there had been a previous convention between Her Majesty's Government and the Transvaal by which the suzerainty of Great Britain was acknowledged, of $\mathrm{I}^{88} \mathrm{I}^{460}$ and I was not prepared without referring to the documents to say how far the convention had been superseded by the Convention of i884.

${ }^{45}{ }^{6}$ Enclosure: untitled extract from the Norddeutsche Allgemeine Zeitung of 5 January i8g6.

${ }^{457}$ Henry Cockayne-Cust; telegram of 4 January I896.

${ }^{458}$ In his telegram of 3 January I8g6 Wilhelm II congratulated the president of the South African Republic, Kruger, on repelling the 'Jameson Raid' (see n. 450 in this section), on restoring peace and maintaining the independence of the country without appealing to the help of friendly powers.

${ }^{459}$ See n. 401 in this section.

${ }^{460}$ The Pretoria Convention (3 August I88I) was the peace treaty between the South African Republic and the United Kingdom which ended the First Boer War. 
Baron von Marschall said that he also would require to refer to the document before expressing a decided opinion, but that he was under the impression that the suzerainty had been completely abolished, and, if this was so, the German Government were perfectly in their right in making any communication they thought fit to the Chief of an independent State. The German Government had certainly no intention or desire to encroach upon any right of Her Majesty's Government but he was under the impression at present that the English press were unjustifiably claiming a right which did not exist and which would certainly be resisted by Germany.

I had a further interview with Baron von Marschall this morning who told me that he had compared the two conventions and had also read the correspondence which had been presented to Parliament on the subject in I884. His Excellency laid great stress upon the fact that all the articles of the Convention of I88I which gave effect to the principle of suzerainty had been omitted in the Convention of I884, and called my attention to Lord Derby's despatch to the Transvaal Deputation of the I5th February i884 in which the following words occur:

"Your Government will be left free to govern the country without interference and to conduct its diplomatic intercourse and shape its foreign policy subject only to the requirements embodied in the $4^{\text {th }}$ Article of the new draft etc".

I replied that I had also been reading the Blue Book $^{461}$ to which His Excellency referred and that, while admitting that the passages he had quoted strongly supported the view taken by the German Government, there was also another view of the question. The limitation contained in Article 4 proved that the independence of the Transvaal was not quite complete, and I reminded His Excellency that a draft submitted by the Deputation, the first article of which provided for the full independence of the South African Republic, had been rejected by Her Majesty's Government. ${ }^{4{ }^{62}}$

Baron von Marschall said that he was still of opinion that the suzerainty had been abolished. In any case Germany had no wish to encroach upon rights we might have and was very sensible to a reproach of that nature; he therefore protested against the attitude of the English press which was likely to embitter the question by putting forward claims which appeared to be in direct contradiction to international treaties.

\footnotetext{
${ }^{461}$ Correspondence respecting the Convention Concluded with the South African Republic on the 27th February I884, March I884.

$4^{62}$ The draft was submitted on 26 November I883; it was rejected by the Earl of Derby in his letter to the Transvaal deputation of 29 November 1883.
} 
His Excellency then repeated the language which he had held to me on the $4^{\text {th }}$ instant with regard to the Emperor's telegram to President Kruger, and I at once drafted my Telegram to Your Lordship, the wording of which was changed more than once in consequence of His Excellency's suggestions before it attained its final form. ${ }^{43}$

Baron von Marschall was at pains to explain that he did not seek to interpret the Emperor's language which, in his opinion needed no justification, but he wished to protest against the interpretation which had been put upon it by the English press.

I thanked Baron von Marschall warmly for this communication which I felt was dictated by a friendly spirit towards Her Majesty's Government although he had been careful to explain that it was not to be considered as an explanation of the Emperor's language. I of course accepted at once his assurance that it was not intended as a hostile act towards England but observed that, considering the wording of the telegram, it was not astonishing that it should have given rise to the idea that it had been dictated rather by animosity towards England than by friendship for the Boers.

Baron von Marschall said that he would admit that there had been considerable suspicion of the action of the Chartered Company and that, even as it was, he did not feel sure that the reports that they were moving more troops were absolutely unfounded. He feared that the Company and more especially Mr Rhodes might give a good deal of trouble to Her Majesty's Government, and he could not conceal from himself that, if Doctor Jameson's attempt had been successful, the Company would have been encouraged to go to greater lengths even against the wishes of Her Majesty's Government. A strong feeling of animosity and distrust certainly did exist in Germany towards the Chartered Company, but this feeling certainly did not extend to Her Majesty's Government.

\section{FO 64/1386: Frank C. Lascelles to Marquess of Salisbury, Africa, Confidential, No 13, 1 I January 1896}

[Received i3 January by bag. For: Print / The Queen / Cabinet / Colonial Office confidential; S[alisbury]]

\section{Discussion of Anglo-German relations with Marschall in the wake of the Kruger telegram}

In a conversation I had this morning with Baron von Marschall, His Excellency alluded to the tone which was still adopted by the English

\footnotetext{
${ }^{46}{ }_{3}$ Frank C. Lascelles' Telegram No 3 to Salisbury, marked Africa, 6 January i896, was drawn up in consultation with Marschall.
} 
Press, more especially the "Times" and the "Standard" towards Germany which would seem to show that public opinion in England was animated by hostile sentiments towards his country. His Excellency could not understand what had caused this feeling and he could assure me that no sentiment of animosity was entertained in Germany, except perhaps in Colonial circles, where we were not popular, towards England, and he was glad to recognize that there had never been a shadow of dissension between the two Governments.

His Excellency added that the Emperor had informed him that he had received a very friendly letter from the Queen ${ }^{464}$ at the end of which Her Majesty had alluded to the unfortunate effect which His Majesty's Telegram to President Krüger [sic] had produced in England. ${ }^{4{ }_{5}}$ The Emperor had replied that he was astonished at the view taken in England of his Telegram which certainly was not intended to be in any way offensive and he was still at a loss to understand how such an interpretation could have been put upon it.

I replied that I was sincerely glad to hear from His Excellency, who I was sure was convinced of my sincere desire that this question should be amiably settled. Personally I had been surprised at the excitement caused by the Emperor's Telegram, which I had been told had been greater than anything known in London since the outbreak of the Crimean War, and I sincerely hoped that the incident might now be considered as terminated.

Baron von Marschall said that everything now depended on President Krüger. If he maintained his moderate and conciliatory attitude, which was probable, as it was palpably his interest to do so, it was not likely that any further incident would arise to prevent a satisfactory solution.

\section{FO 64/1386: Frank C. Lascelles to Marquess of Salisbury, Africa, Confidential, No 58, 24 April 1896}

[Received 27 April by messenger. For: Print / Mr Balfour / Duke of Devonshire / Mr Chamberlain; S[alisbury]]

Marschall's complaint about misleading British press portrayals of German relations with the Transvaal

In conversation with Baron von Marschall this morning I alluded to the language recently held by the Emperor to Colonel Grierson at

\footnotetext{
${ }^{464}$ Victoria to Wilhelm II, dated Osborne, 5 January I896.

${ }^{46}$ For the so-called Kruger telegram see n. $45^{8}$ in this section.
} 
Coburg which formed the subject of my Despatch $\mathrm{N}^{\mathrm{o}}$ I 12 of this day's date..$^{46}$

His Excellency said that he could quite understand the Emperor's complaints against the English Press, which appeared to be animated by a desire to excite public opinion in England to such an extent as to render war with the Transvaal inevitable. His Excellency alluded to the alarmist telegrams which had recently appeared in the "Times" and which were absolutely inaccurate, the evident object of which was to create the impression that Germany was actively interfering in the Transvaal: His Excellency especially referred to the telegram with regard to the arrival of the German Steamer "Bundesrath" in Delagoa Bay, which formed the subject of my Despatch $\mathrm{N}^{\mathrm{O}} 55$ Africa of the $23^{\text {rd }}$ instant. $^{467}$

Baron von Marschall went on to say that these alarmist telegrams had produced a great effect in England and he had observed that $\mathbf{M}^{\mathrm{r}}$ Chamberlain in a recent speech ${ }^{468}$ had thought it necessary almost to declare war against any Power who should interfere in the Transvaal. His Excellency did not see the necessity for this remark of $\mathrm{M}^{\mathrm{r}}$ Chamberlain's, and he thought that the publication of the White Book $^{469}$ and his own speeches in the Reichstag would have had the effect of convincing people in England that there had been no interference on the part of Germany. His Excellency believed that the Transvaal Government were prepared to consider the legitimate grievances of the Outlander ${ }^{470}$ population which, it was generally admitted, ought to be redressed. The rapid and increasing development of Johannesburg, which had completely outgrown the administrative arrangements of Boers, was one of the difficulties which would have to be dealt with; and it was evident that it would be impossible to confer political rights upon persons who had merely gone out in the hope of making their fortunes without any intention of permanently remaining in the country, many of whom would not be desirable citizens. But however this might be, His Excellency could not but think that the tone adopted by the majority of the English Press, and even $\mathrm{M}^{\mathrm{r}}$ Chamberlain's remarks about the

\footnotetext{
${ }^{466}$ Lascelles is referring to Grierson's conversation with Wilhelm II as they attended the wedding of Princess Alexandra of Saxe-Coburg and Gotha and Ernst II, Prince of Hohenlohe-Langenburg, which took place on 20 April 1896.

${ }^{467}$ According to a report from Barberton, printed in the Times of 20 April I896, uniforms and other military equipment had been found in the luggage of German passengers on board the Bundesrath, which had landed at Delagoa Bay on I4 April.

${ }^{468}$ Marschall was referring to Chamberlain's speech at the Constitutional Club, London, on 22 April I8g6.

${ }^{469}$ Aktenstïcke betreffend die Südafrikanische Republik, published on I2 February I896.

${ }^{470}$ Outlander or Uitlander; Afrikaans for 'foreigner' (see n. $45^{\circ}$ in this section).
} 
corruption of the Transvaal Government ${ }^{471}$ were scarcely calculated to bring about an amicable understanding.

\section{FO 64/1377: Martin Gosselin to Marquess of Salisbury, No 185 , Berlin, 19 June 1896}

[Received 22 June by messenger. For: African Department; S[alisbury]]

Dispute between Daily Telegraph's correspondent to Berlin and a clerk of the Imperial Telegraph Office; politicized by Anti-Semites in Reichstag

A dispute which arose last month between $\mathrm{M}^{\mathrm{r}}$ Bashford, the Berlin correspondent of the Daily Telegraph, and one of the Imperial Telegraph Office clerks has for some days past been discussed in the Berlin newspapers, and was brought before the notice of the Reichstag yesterday.

I have the honour to enclose copy and summary of a statement published by $\mathrm{M}^{\mathrm{r}}$ Bashford on the subject, together with a précis by $\mathrm{M}^{\mathrm{r}}$ Spring Rice of the statement made in the Reichstag ${ }^{47^{2}}$ by $\mathrm{D}^{\mathrm{r}}$ von Stephan, the Postmaster General on the incident. ${ }^{473}$

The motion brought forward by Herr Liebermann and supported by 30 Anti-Semites was to the following effect:

(I) Does the Imperial Chancellor ${ }^{474}$ know that the Telegraph Clerk Kaiser on the $\mathrm{IO}^{\text {th }}$ of May last was, while engaged in his work in the Post Office, abused and insulted by the English newspaper correspondent Bashford; and (2) Is the Chancellor aware that the insulted official was induced, through the influence of the Postmaster General, to forego bringing an action, the offender having merely to pay Mks. Ioo compensation [Note in margin: 'Mks. IOO $=£ 5$ '] and to make a verbal apology.

After hearing the Postmaster General's explanation of the incident, the House declined to allow the motion to be discussed, and the question was dropped.

Baron von Marschall told me this morning that the motive of the attack made on $\mathrm{M}^{\mathrm{r}}$ Bashford was the belief that he is a Jew, "whereas he is, I believe, an excellent Christian"; that there could be no doubt that the clerk was in the wrong, in declining to forward the telegram

\footnotetext{
${ }^{471}$ In his speech of 22 April Chamberlain characterized the Transvaal government as 'defective and corrupt'.

${ }^{472}$ On i8 June i896.

${ }^{473}$ Enclosures: 'Reichstags- Verhandlungen' ('Reichstag proceedings'), Norddeutsche Allgemeine Zeitung, I9 June I896. Report entitled 'The Bashford Case' based on an uncited Norddeutsche Allgemeine Zeitung article of 17 June 1896. Précis by Spring-Rice entitled 'Interpellation of the Antisemites on the subject of Mr Bashford', I8 June I896.

${ }^{474}$ Chlodwig zu Hohenlohe-Schillingsfürst.
} 
till paid for; a proceeding which His Excellency explained by the fact that the clerk in question was not the ordinary official for the Despatch of Press Telegrams, but an extra hand employed on Sundays; that very possibly $\mathrm{M}^{\mathrm{r}}$ Bashford had been somewhat hasty in his remarks; but that there was no idea (as suggested by Herr Liebermann) of ordering him to leave Berlin.

My own impression is, that the Anti-Semites availed themselves of the somewhat trumpery incident to attack the Postmaster General, in the hopes of being able to oust him from his post, an official who though one of the ablest in the Imperial Service, has more than once found himself in opposition to the policy advocated by Agrarian and Anti-Semite Agitators.

It is, however, somewhat unfortunate that $\mathrm{M}^{\mathrm{r}}$ Bashford should be the Berlin Agent of the South African territories Company Limited, which, as reported in my despatch $\mathrm{N}^{\circ} 9^{2}$ Africa of the $3^{\text {rd }}$ instant, got into trouble only the other day by the appointment of $\mathrm{M}^{\mathrm{r}}$ Fort as their Local Manager at Warmbad, in German South West Africa. ${ }^{47}$

\section{FO 64/1387: Martin Gosselin to Marquess of Salisbury, Africa, No 124, 15 July 1896}

[Received 20 July by bag. Print (East Africa); 'Consult Mr Hardinge, Sir H. Johnston and India Office', G.Ll.H. [Clement Lloyd Hill]; S[alisbury]; 'Answered No I32', I7 August $]^{476}$

Conversation with Paul Kayser on the establishment of game reserves in East Africa

With reference to my despatch No Io4 Africa of the 22nd ultimo, respecting the protection of big game in German East Africa, I

${ }^{475}$ On 2 June G. Seymour Fort resigned from his post as managing director at Warmbad as a result of an article on the 'Jameson Raid' (see n. 450 in this section), published in the June issue of The Nineteenth Century, In this he insinuated secret understandings between Germany and the Transvaal.

$4^{47}$ Notes on docket (also printed as official Minutes on Berlin No I24, Africa, July I5 1896). 'See typed copy of following: The subject is one that requires very careful consideration. I will submit an expression of my views separatly [sic], or rather a compromise between my own views \& those of Mr Alfred Sharpe, as I find there is some divergence between them and that Mr Sharpe in his recent private correspondence can adduce good reasons for not following me more than a certain distance in my desire to control the destruction of certain animals.' H.H.J. [Henry Hamilton Johnston]; 'I have not read Major von Wissmann's proposals, but in principle I think it very desirable that a sort of "park" should be marked out, within which certain animals should be sacred. I have discussed this question with several Officials at Mombasa \& think we should reserve a certain district in Kikuyu and another in Ukambani and perhaps another on the Tana. We should have to have 3 European rangers whose business it would be to see that our regulations were observed. When the railway is made, Africa will be flooded with Sportsmen making 
have the honour to report that I enquired this morning of Dr Kayser how Major von Wissman meant to enforce respect for his proposed sanctuaries, without incurring any considerable expense. ${ }^{47}$

Dr Kayser replied that he had put this very question to Major von Wissman on his return here the other day to Berlin. ${ }^{47^{8}}$

Major von Wissman had explained that the nearest stations to the reserves would be charged with the carrying out of his game regulations, and that as far as European sportsmen go, he did not anticipate any insuperable difficulties; with native hunters it will of course be more difficult to deal; but the Major is of opinion that if the system of sporting licences is strictly enforced, and the first few offenders duly punished, it will be quite possible to ensure a considerable amount of respect for the game reserves.

Major von Wissman is himself in favour of some international agreement being come to between all the Powers on the East African littoral for the protection of game in the interior.

Dr Kayser said that while he personally entirely sympathised with this suggestion he foresaw difficulties in carrying it out; for instance the Portuguese might agree to the plan on paper, but they had no means, even with the best will in the world, for carrying it out on the Mozambique coast.

Dr Kayser had no doubt that the British and German authorities would heartily co-operate in the effort to protect elephants and other big game from extermination; but that if the natives found that by

for the Athi plains. We should not lose in B.E.A. [British East Africa] by the diversion of trade to Portuguese Africa - our ivory hunters would not go so far South. There is already a Company's regulation prohibiting the killing of cow-elephants \& I believe the tusks can be distinguished from the bulls', so there ought to be no difficulty in enforcing it. I would suggest sending Major von Wissmann's proposals to Mr Crawford \& asking him to draft a set of regulations for B.E.A. following the German lines wherever practicable or advisable.' A.H.H. [Arthur Henry Hardinge]; 'Sir John Kirk thinks that we should do better by keeping sportsmen out of certain large areas than by attempting to control what foes are within them. He would strictly enforce against sportsmen the regulations of the Brussels Act as to stamping arms \& the regulations as to licenses already existing. He thinks the areas should not be traversed by a main road, shd not be near a foreign frontier \& shd not be in too thickly inhabited districts \& that they shd be large. He suggests that one might be near the Tana, and then in the Kenia ranges, \& a third on the Man heights, but agrees in asking local advice. We have already called special local attention to the matter \& might now, as suggested by Mr Hardinge, tell Mr Crawford to draft regulations for approval.' C.Ll. H. [Clement Lloyd Hill], 3 August; S[alisbury]; Draft, I4 August \& Draft, Sir F. Lascelles, No I32, I7 August].

${ }^{477}$ On 7 May I896 Hermann von Wissmann, governor of German East Africa, issued a wildlife ordinance which stipulated restrictive regulations for hunting. A Runderla $\beta$ (circular directive) of the same day justified these measures and proposed the establishment of game reserves; the first two were to be west of Mount Kilimanjaro and on the Rufiji River.

${ }^{478}$ Wissmann had left Africa on II May I896 and visited Berlin in early July. 
crossing the Rovuma they could find a ready market for their ivory, all the ivory trade on the east coast would be diverted to the Portuguese possessions; England and Germany would be the losers; while no protection would be afforded to the African elephant.

The only means he could see by which the depredations of sportsmen (both European and native) could be checked would be for the Powers to fix, by international agreement a close time for elephants and hippopotami, and to authorise the confiscation by the authorities on the littoral of all tusks under a certain weight.

Dr Kayser said he would be glad if I would mention this suggestion to Your Lordship as a possible solution of the question, though he feared that it would be very difficult to ensure the adequate carrying out of any such a measure by the Portuguese authorities on the Mozambique coast.

If the British authorities concerned have any suggestion to make on the subject, Dr Kayser assured me he would gladly give them his earnest consideration.

In view of the fact that a question was asked in the House of Commons on the 3oth ultimo, respecting the establishment of a reserve or sanctuary for elephants within the British Somali Land Protectorate, I venture to report Dr Kayser's observations to Your Lordship for the information of the India Office.

\section{FO 64/1387: Martin Gosselin to Marquess of Salisbury, Africa, No 133, 23 July 1896}

[Received 27 July by messenger. For: Colonial Office with No I28, P.L. [printed letter], 4 August; S[alisbury]]

\section{Discussion with Paul Kayser on penal settlements in German colonies}

With reference to my despatch $\mathrm{N}^{\mathrm{o}}$ I28 Africa of the $20^{\text {th }}$ instant, I have the honour to enclose a summary by $\mathrm{M}^{\mathrm{r}}$ Whitehead of a leading article in last night's "Norddeutsche" on the subject of the establishment of penal settlements in German Colonies. ${ }^{479}$

I asked $\mathrm{D}^{\mathrm{r}}$ Kayser today whether the German Government had any immediate intention of adopting the scheme, which has met with warm support in the Colonial Society's recent meetings. ${ }^{40}$

$\mathrm{D}^{\mathrm{r}}$ Kayser replied that the Colonial Department saw no reason to prevent an examination of the question, which was favoured by the

\footnotetext{
${ }^{479}$ Enclosure: précis of a leading article in the Norddeutsche Allgemeine Zeitung of 22 July I896 on the question of deporting criminals to South West Africa.

${ }^{480}$ On 30 May I 896 the general meeting of the Colonial Society referred the question of penal settlements to the society's standing committee.
} 
Professors and the Parsons - two powers in the State whom he could not afford to neglect; he had consequently a few days ago given a letter of introduction to an acquaintance in Paris for a gentleman who was about to visit France, on behalf of the supporters of the scheme, to investigate into the French system of transmarine penal settlements; but he did not anticipate that anything would come of the movement.

In the first place it was a question about which the Department of Justice would have a weighty word to say; and $\mathrm{D}^{\mathrm{r}}$ Starke, one of the leading officials of that Department in criminal matters, was strongly opposed to the scheme. It was calculated that each prisoner in Prussia costs the State one Mark a day - (including general prison expenditure and maintenance); if the criminals were transported, the average expenditure would be tenfold that amount: this alone, said the Doctor, would be sufficient to damp the ardour of the Government.

Then, the Department of Justice would never sanction "a slow death sentence" by the deportation of criminals to unhealthy Colonies: a German Cayenne would be an impossibility; ${ }^{481}$ the only colony which could ever be used for such a purpose would be South West Africa; and the Government, if they had funds at their disposal, would prefer to assist free immigration there than to embark on a large expenditure on behalf of the criminal classes of the country.

In reply to my enquiry whether it is a fact, as stated in the "Norddeutsche's" Article, that the French Government have established penal settlements at Obok and Gaboon, $\mathrm{D}^{\mathrm{r}}$ Kayser said he had never heard of them, and thought the statement incorrect.

\section{FO 64/1379: Frank C. Lascelles to Marquess of Salisbury, Confidential, No 310, Berlin, I5 October 1896}

[Received i9 October by messenger. For: The Queen / Prince of Wales / Duke of Devonshire / Mr Balfour / Mr Chamberlain / Eastern Department / African Department; S[alisbury]]

Hatzfeldt apologetic about the sorry state of Anglo-German relations; blames Britain's unclear policy towards Turkey; discussion of colonial matters

Count Hatzfeldt, who is staying for a few days in Berlin, ${ }^{482}$ was good enough to call upon me today. His Excellency spoke to me very openly about the relations between England and Germany, and

\footnotetext{
${ }^{48 \mathrm{r}}$ Kayser was referring to the Bagne de Cayenne (Devil's Island), a penal colony in French Guiana.

${ }^{482}$ Hatzfeldt was on leave of absence from I September. He returned from Sommerberg to London in mid November 1896 .
} 
regretted that they were no longer on their former satisfactory footing. His Excellency considered that this was due to the change which took place some years ago in English policy with regard to Turkey. ${ }^{483}$ Before then, it was a recognized axiom that England would do all in her power to maintain the integrity of the Turkish Empire. There was now however considerable doubt as to the line which England would take if the Eastern question were reopened, and it was evident that under these circumstances there must be some hesitation on the part of other Governments until they knew the line which Her Majesty's Government might decide to adopt.

His Excellency personally did not attribute much importance to the differences with regard to Colonial questions which had arisen between the two countries. They were not of sufficient importance to bring about a permanent estrangement between the two countries. With regard to the case of Said Khalid, ${ }^{484}$ His Excellency said that he was convinced that in similar circumstances England would have refused to give him up, and in proof of this he cited the case of Witbooi who had given great trouble to the German Authorities in South West Africa, and who had not only not been given up by the Cape Authorities, but had been allowed sufficient liberty to be able to enter German territory and create trouble, and then to take refuge in the territory of the Chartered Company. ${ }^{4{ }^{8}}$ His Excellency thought that the action of the German Government with regard to Said Khalid would compare favourably with that of the Cape Authorities with regard to Witbooi, but however this might be, there was no doubt that the relations between England and Germany were far from being on a satisfactory footing, and he had considered it his duty to inform the Emperor that there were people in England, and even influential people, who contemplated the possibility of a war with Germany. His Majesty had expressed the greatest astonishment that this should be the case, and His Excellency himself did not believe that the irritation which no doubt existed on both sides would lead to war, but the change which had taken place in recent years with regard

\footnotetext{
${ }^{483}$ Hatzfeldt was referring to Britain's policy towards Turkey since 1895. As he understood it, Great Britain - in light of the Turkish policy towards the Armenian people and the Hamidian massacres - was considering the division of the Ottoman Empire and thus abandoning the leading principle of her Eastern policy.

${ }^{484}$ Khalid succeeded to the position of Sultan of Zanzibar without British consent, on 25 August 1896. On the day of the one-day Anglo-Zanzibar War, on 27 August, he took refuge at the German consulate. On 2 October he was brought to Dar es Salaam (German East Africa) where he sought political asylum.

${ }^{485}$ British South Africa Company (founded I889). Hatzfeldt was referring to conflicts with the German colonial authorities in German South West Africa (Namibia) from I888, when Hendrik Witbooi became chief of the |Khowesin (Witbooi) people. He conditionally surrendered in 1894 .
} 
to the policy of England on the Eastern question had given rise to grave doubts as to the line she would adopt if the question were reopened. His long residence in England had given him an insight into English character, which was little understood on the Continent, and, although he was perfectly aware that the recent movement in England with regard to the Armenian massacres had been dictated solely by disinterested and humanitarian motives, ${ }^{466}$ he found it almost impossible to convince people here that England ever acted except from selfish motives, or allowed her political action to be influenced by sentimentality.

\section{FO 64/1379: Frank C. Lascelles to Marquess of Salisbury, No 321, Berlin, 27 October 1896}

[Received 2 November by bag. For: Print (West Europe) / The Queen / Prince of Wales / Mr Balfour / Duke of Devonshire; Confidential to: St Petersburg / Vienna / Rome; Cabinet; S[alisbury]]

Surprising press reports on secret Reinsurance Treaty and Russia; Russo-German relations during reign of Alexander III

I have the honour to enclose to Your Lordship, herewith, copy and translation of a notice which has appeared in the "Reichs Anzeiger" relative to an Article published in the "Hamburger Nachrichten", ${ }_{487}$ which is generally supposed to be Prince Bismarck's organ.

In this article it was stated that ["] soon after the accession of the Czar Alexander III $^{488}$ good relations were established between Germany and Russia, which lasted till I89o. Till that date both nations had a full understanding that if one was attacked without provocation the other would maintain an attitude of friendly neutrality. This understanding came to an end with Prince Bismarck's retirement not because of Russia's unwillingness to renew it but because Count Caprivi refused to prolong the mutual policy of insurance". This, says the writer, was the origin of Russia's friendship for France, for her isolation, in consequence of Germany's changed attitude left her no other choice.

The Article has excited a very great amount of interest in Germany, which has resulted in the official notice, which I have

\footnotetext{
${ }^{486}$ Lascelles is referring to the Hamidian massacres against the Armenian population of the Ottoman Empire; see also n. 557 in Dresden section.

${ }^{487}$ The secret Reinsurance Treaty between Germany and Russia of I8 June I887 - and its non-renewal in 1890 - was exposed in the Hamburger Nachrichten of 24 October I896. The notice in the Deutscher Reichs-Anzeiger und Königlich Preußischer Staats-Anzeiger was published on 27 October. Enclosure: clipping entitled 'Deutschland. Die Hamburger Enthüllungen', and translation (both undated).

${ }^{488}$ i3 March i88I.
} 
the honour to enclose to the effect that the Government has no statement whatever to make on a subject which belongs to the domain of official secrecy, where any disclosure whatever would entail injury to state interests of the gravest kind.

The statement apart from general considerations is of a sufficiently surprising nature. Alexander III succeeded to the throne in I88I. The history of the ensuing years is full of the antagonism between Russia and Germany. The Imperial Bank took hostile action against Russian securities. The army was increased in 1887 precisely on account of the alleged danger of a Russian attack: the German-Austrian Treaty was ostentatiously published in $1888^{489}$ and on the $6^{\text {th }}$ of February of that year Prince Bismarck made his famous speech ${ }^{49^{\circ}}$ in which he said that Russia had turned her old friend Germany out of doors, and concluded with the famous words - "We Germans fear God but nothing else in the world"[.]

But the most remarkable aspect of the statement is the fact that the Treaty was concluded with Austria in 1879 and that, if what is alleged is true, an understanding was made shortly afterwards ${ }^{491}$ with Russia to the knowledge of which Austria does not appear to have been admitted.

\section{FO 64/1379: Frank C. Lascelles to Marquess of Salisbury, Secret, No 339, Berlin, 5 November 1896}

Received 9 November by bag. For: The Queen / Mr Balfour / Duke of Devonshire; Secret to: Paris / St Petersburg / Peking; 'It is not Mickie but Michie. He is or was a merchant at Tientsin: \& is a well informed and far sighted authority.' G.N.C. [George N. Curzon]; S[alisbury]]

Similarity of German and British interests in China; need for cooperation to guard against internal and external threats

I have the honour to inclose an interesting Memorandum by $\mathrm{M}^{\mathrm{r}}$ Spring-Rice of a conversation he has had with $\mathrm{M}^{\mathrm{r}}$ Detring, who is about to resume his duties in China. ${ }^{492}$

\footnotetext{
${ }^{489}$ In the secret treaty of 7 October 1879 (published on 3 February I888), which brought about the so-called Dual Alliance, Austria and Germany pledged to aid one another in the case of an attack by Russia, or in the event of an attack by a Russian-supported power. In all other cases it was agreed to observe benevolent neutrality.

${ }^{490}$ See pp. 303-304.

${ }^{491}$ The date of the Reinsurance Treaty (1887) was not disclosed by the Hamburger Nachrichten and still unknown at the time of the dispatch.

${ }^{492}$ Enclosure: secret memorandum recording conversation between Spring-Rice and Mr Detring, undated.
} 
I have had an opportunity of conversing with $\mathrm{M}^{\mathrm{r}}$ Mickie [sic ${ }^{493}$ to whom allusion is made in the Memorandum, and who is strongly of opinion that English and German interests are identical in China and that it is of the utmost importance that the two nations should act, if not in cooperation, at all events on parallel lines. If France and Russia were to encroach on China the one from the South and the other from the North, the Commercial interests both of England and Germany would be fatally affected. $\mathrm{M}^{\mathrm{r}}$ Mickie pointed out that there were two dangers which threatened the present Chinese Dynasty. ${ }^{494}$ One was a popular rising such as the Taiping rebellion, ${ }^{495}$ and the other was an intrigue against the present Emperor, whose right to the throne had been contested and who was popularly supposed to be incapable of leaving a direct heir. ${ }^{496}$ An attack against the Dynasty either in the shape of a Palace intrigue or of a popular rising would probably, if successful entail a long period of anarchy in China, of which it was probable that France and Russia would take advantage to the detriment of the commercial interests of England and Germany. It was only natural that each of the two latter countries should strive to push their own interests, but it would be of great advantage to both if they could be brought to understand that they were both threatened by the same dangers, and that they should act together in order to avoid them.

\section{FO 64/1379: Frank C. Lascelles to Marquess of Salisbury, Confidential, No 356, Berlin, 20 November 1896}

[Received 23 November by bag. For: The Queen / Prince of Wales / Duke of Devonshire / Mr Balfour; Confidential to: Paris / Vienna / St Petersburg / Rome / Constantinople; African and United States departments to see; Print for Cabinet; S[alisbury]]

Debate on disclosed Russo-German Reinsurance Treaty; conversation with Marschall regarding anti-English feeling in Reichstag debate and different parts of the German political spectrum

With reference to my despatch No. 349 of yesterday's date, I have the honour to report that I took an opportunity this afternoon of congratulating Baron von Marschall on the favourable impression which had been produced by the debate in the Reichstag on the

\footnotetext{
${ }^{493}$ Alexander Michie.

${ }^{494}$ Qing dynasty.

495 The Taiping Rebellion of I850-1864 was a civil war between the Qing government and the religious-social movement of the Heavenly Kingdom of Peace in southern China.

${ }^{496}$ Guangxu Emperor; he was enthroned as emperor despite belonging to the same generation as his predecessor and cousin, Tongzhi Emperor.
} 
Bismarck revelations. ${ }^{497}$ I said that I was also glad to hear that His Excellency's speech had caused satisfaction at Vienna and Rome.

Baron von Marschall thanked me and said that his task had been a most difficult one, as it had been impossible for him to speak openly on the subject, and he was glad to say that the favourable impression which had been created in Austria and Italy was shared also to a certain extent in Russia, although Count Osten Sacken had urged to maintain complete secrecy with regard to the Treaty which expired in I89o. He had explained to Count Osten Sacken that although he would certainly not make any revelations on the subject, it was impossible for him to contradict Prince Bismarck, who had himself signed the Treaty, and the very fact of his not denying the existence of the Treaty could not fail to be taken as a tacit avowal of its having existed. Count Osten Sacken had agreed that this was the case, and had apparently been satisfied with the speech, which had not been unfavourably received by the Russian Press.

I went on to say that while I rejoiced that the Government had extricated themselves from the very difficult position in which they had been placed by Prince Bismarck's revelation, I could not but regret the Anti-English feeling which prevailed in the Reichstag.

His Excellency answered that the Bismarckians were certainly Anti-English. It had in fact invariably been Prince Bismarck's habit to proclaim hostility to England, although in his political action he had frequently shown that he was not unfriendly to her, but he doubted whether the other sections of the Reichstag entertained any Anti-English sentiments, while the Left were decidedly Anglophil[e].

I observed that the Centre ${ }^{49^{8}}$ appeared to me to have shown a decidedly Anti-English tendency, and His Excellency's speech itself contained two statements which I could only regard as being directed against England. At His Excellency's request, I quoted the two passages to which I drew Your Lordship's attention in my abovementioned despatch.

Baron von Marschall replied that his allusion to the joint action of Germany with Russia and France last year in the Far East ${ }^{499}$ was a

\footnotetext{
${ }^{497}$ Lascelles is referring to the Reichstag debate of 16 November I896. For the disclosure of the existence of the Russo-German Reinsurance Treaty, and its non-renewal in I89o, see n. 487 in this section.

${ }^{498}$ Zentrumspartei (Catholics).

${ }^{499}$ The so-called Triple Intervention of 23 April I895 demanded the return of the Liaodong Peninsula from Japan to China, which had previously been ceded by China in the peace treaty of Shimonoseki of I7 April I896. In his Reichstag speech Marschall stated that German overseas interests would probably provide future opportunity for the co-operation of the three powers.
} 
confirmation of his statement that the relations of Germany and Russia were on a satisfactory footing, and his expression of the desire of the German Government to maintain friendly relations with other Powers and to recognize their rights to the same extent as they recognized the rights of Germany was merely an amplification of the remarks he had made in an earlier part of his speech, that good relations between Germany and Russia must depend upon reciprocity. ${ }^{500}$

Baron von Marschall added that he did not consider that the Centre was animated by Anti-English sentiments. He thought that it was rather Anti-Russian, but Prince Bismarck's revelations had done enormous harm in two respects. They had in the first place given rise to the suspicion that the Emperor allowed himself to be guided by the influence of the Empress Frederick ${ }^{501}$ to follow a policy which might not be in accordance with the true interests of Germany, and on this point all Germans were particularly sensitive, and in the second place they had asserted that the Franco-Russian understanding had been brought about by the refusal of Prince Bismarck's successor ${ }^{502}$ to renew the secret Treaty with Russia. In a Bismarckian Newspaper which he had just received it was stated that, although the Treaty with Russia may not have been officially communicated to the English Government, there existed family relations by which communications could be made without the knowledge of the responsible Ministers. Such statements, which were no doubt inspired by Prince Bismarck, were most perfidious and would excite animosity against the Empress Frederick, and through her against England, and he could not conceal from me that the action of Her Majesty's Government with regard to Said Khaled $[\text { sic }]^{503}$ had produced a most unfavorable impression in Germany.

I did not think it necessary to prolong the discussion, as I thought I had done enough in showing His Excellency that the remarks in his speech against England had not passed unnoticed, but I asked him whether Prince Bismarck's adherents did not perceive that the revelations were more damaging to the Prince's reputation than to anyone else.

Baron von Marschall replied that the majority of Bismarckians had such faith in the Prince that in their eyes he could not be wrong, but that he had every reason to believe that Count Herbert Bismarck, who had attended the sitting of the Reichstag no doubt with the

\footnotetext{
${ }^{500}$ In his speech Marschall expressed the general German desire for friendly relations with 'other powers with that respect for their rights which they may accord to ours'.

${ }^{501}$ Victoria.

${ }^{502}$ Leo von Caprivi.

${ }^{503}$ Sayyid Khalid; see n. 484 in this section.
} 
view of defending his Father if necessary, deplored the action which the Prince had taken, and strongly disapproved of the revelations.

\section{FO 64/1379: Frank C. Lascelles to Marquess of Salisbury, Confidential, No 368, Berlin, 28 November 1896}

[Received 30 November by messenger. For: The Queen / Duke of Devonshire / Mr Balfour / Secret to Home Office (with reference H.E. Telegram No 4, 28 November ı896), P.L. [printed letter], 2 December; S[alisbury]]

Discussion with emperor about Hamburg strike; suspected British support; dangers of increasing anti-English feeling in southern Germany

At a quarter before eight this evening I received a visit from Baron von Senden Bibran the head of the Emperor's Naval Cabinet who told me that His Majesty who was on his way back to Potsdam desired to see me as soon as possible. I told the Admiral that I should at once obey His Majesty's commands by taking the train which left Berlin for Potsdam at five minutes past nine, and shortly afterwards I received a Telegram from His Majesty requesting me to come to Potsdam immediately.

I had the honour in my Telegram No 49, to report to your Lordship the principal points of His Majesty's remarks with regard to the Hamburg strike which evidently had deeply impressed His Majesty as being not merely a local outbreak, but a carefully organized international movement. ${ }^{504}$ There had been no justification for the strike. The dock labourers were receiving wages which would command the services of skilled artizans, and the strike appeared to be collapsing when it suddenly revived on the appearance of $\mathrm{M}^{\mathrm{r}}$ Tom Mann in Hamburg. ${ }^{505}$ There were 45000 workmen in Hamburg of whom I0,000 were on strike. Their places were filled up by importations from other ports of Germany, and even from England, but it was to be expected that the men on strike would oppose the employment of imported labour, and that disturbances might ensue. There was no danger of serious disorder as General von Waldersee who was in command would certainly repress any disturbance with severity and the Socialists would probably receive a lesson which would keep them quiet for the next twenty years, but incalculable harm would be done if Hamburg and the Elbe which

\footnotetext{
${ }^{504}$ The Hamburg dock strike began on 2I November I896 and ended, unsuccessfully, on 6 February 1897 .

${ }^{505}$ Tom Mann, a British trade unionist, who had been evicted from Hamburg on I5 September, returned on 23 November. He was arrested on 26 November.
} 
had hitherto been friendly to England began to believe that English capital had supported the Hamburg strike with the object of damaging German commerce.

I told The Emperor that I would not fail to report to Your Lordship the observations which His Majesty had made, but I remarked that although Socialists all over the world might act together it was inconceivable that English commerce should seek to win Hamburg with whom it had such vast interests.

His Majesty replied that the Anti English feeling which was prevalent in South Germany seemed to be increasing, and that if it extended to Hamburg and the Elbe the relations between the two countries would become so embittered that there would be an estrangement between them, which would last for at least fifty years, of which no doubt both France and Russia would take full advantage.

\section{FO 64/1409: Frank C. Lascelles to Marquess of Salisbury, Confidential, No 41, Berlin, 12 February 1897}

[Received I5 February by bag. For: The Queen / Prince of Wales / Duke of Devonshire / Mr Balfour / Commercial Department / Admiralty - confidential / Cabinet; S[alisbury]]

Political effects of Germany's growth in industrial production and foreign trade; weak naval power renders Germany precarious in times of war

I venture to draw Your Lordship's attention to the speech recently delivered in the Reichstag by Baron von Marschall, reported in my despatch No 38 Commercial of the Ioth instant, and to the communication of the Emperor to the Reichstag of which I sent a translation in my despatch No 39 of this series of today's date..$^{506}$

The gist of these statements appears to be that this Government is deeply impressed with the changed conditions brought about by the great development of German industry.

Germany is no longer a country living on its own resources; it is fed from abroad and it pays for its food by the products of German industry which from year to year take more decidedly the character of elaborately manufactured products, the raw material of which comes from foreign countries. In the mean while the urban population of Germany is increasing at a far more rapid rate that the population of the country districts and the proportion of the German people who are engaged in the production of food stuffs is yearly diminishing.

\footnotetext{
${ }^{506}$ Lascelles is referring to Marschall's speech of 8 February I897 which dealt with future German trade policy and commercial treaties. For the communication of the emperor see n. 508 below.
} 
This tendency has a two-fold effect on German politics.

On the one hand it has produced the agrarian movement the main strength of which lies in the sentiment expressed in the article from the Norddeutsche ${ }^{507}$ which I had the honour to transmit in my despatch No 40 of this series of today's date. This is, in brief, firstly that Germany must, as far as possible, provide her own food, and secondly that the fighting strength of Germany lies in a prosperous country population. Hence arises the desire which is constantly apparent in the public utterances and the legislative proposals of the Government to do all that is possible for the landed interest, landlords and farmers.

But this tendency has another and a more striking consequence. Germany depends for part of her food supply on foreign countries, and, for the pecuniary resources which enable her to meet her military expenses, on foreign trade. And, as is apparent from the tables communicated by the Emperor to the Reichstag ${ }^{508}$ Germany disposes of a sea power greatly inferior to that of France and Russia. The sea approaches of Germany are at the mercy of a combination between France and Russia or of France alone. And Germany accepted the doctrine of sea law advanced by France at the time of her hostilities with China, that the necessaries of life were contraband of war..$^{509}$ In case of a war with France the food supply of Germany would be drawn (as they are now drawn in yearly increasing proportion) from Russia. But if she were at war with both France and Russia for any length of time the economical and political position of Germany, with the enormous number of socialists in her midst, would be indeed perilous.

In the report recently published by the Board of Trade ${ }^{50}$ it is stated that the tendency noticed, - of the development of the industrial activity of Germany, - it is likely to continue if peace is assured. I venture to think that peace is not only a condition of German prosperity but is regarded in many quarters as almost a condition of her existence.

\footnotetext{
${ }^{507}$ Lascelles is referring to the editorial titled Unsere Handelspolitk (Our Trade Policy) in the Norddeutsche Allgemeine Zeitung of in February I897.

${ }^{508}$ On in February i897 Wilhelm II presented the Reichstag library with tables that he had drawn up himself, which compared the naval strength of Germany, France, Russia, the United States, Japan, and France.

${ }^{509}$ Lascelles is referring to the Sino-French War when, in February 1885, France declared rice as contraband. Unlike Great Britain, Germany did not protest against this measure.

${ }^{{ }^{10}}$ Board of Trade, Memorandum on the Comparative Statistics of Population, Industry, and Commerce in the United Kingdom and some Leading Foreign Countries, presented to both Houses of Parliament by Command of Her Majesty, January I897 [C.8322].
} 


\section{FO 64/1410: Frank C. Lascelles to Marquess of Salisbury, No r34, Berlin, I4 May 1897}

[Received I7 May by bag. For: The Queen / Prince of Wales / Duke of Devonshire / Mr Balfour, A.J.B. [Arthur James Balfour]; S[alisbury]]

\section{Public feeling exasperated by repeated ineptitude of administration}

The recent debate on the subject of the law of High Treason and the publication of the bill respecting the right of association and public meeting have directed the attention of the press and public opinion to the principles under which the present Government is administered. ${ }^{.11}$

So far as comments are possible under the severely restrictive laws of Germany, it would appear that public feeling has been deeply stirred by the recent irresponsible utterances of the $\mathrm{crown}^{512}$ and by the obstacle which would seem to be encountered by ministers in carrying out their pledges to the peoples' representatives.

Reiterated promises have been made to the Reichstag that the military penal laws will be reformed, and after the retirement of one minister ${ }^{513}$ and numerous rumours of Cabinet crises [Note in margin: '(See No 3 Jan I)'] (as to which the Tausch trial offered an interesting commentary $)^{514}$ a bill in the above sense has only now been submitted to the Bundesrath. ${ }^{515}$

A year ago the Reichstag ${ }^{516}$ consented to the withdrawal of a resolution for the abolition of the restriction on the right of association on the receipt of a pledge from the Government that a bill in that sense would shortly be presented. Such a bill has only been published, and contains provisions which make its rejection almost certain. ${ }^{57}$

\footnotetext{
${ }^{511}$ Lascelles is referring to the Reichstag motion by August Bebel of 12 May 1897 to abolish the classification of lèse-majesty as criminal offence and to the bill respecting the right of assembly and association, introduced in the Prussian house of deputies on I3 May I897.

${ }^{12}$ Lascelles is probably referring to Wilhelm's telegram to his brother Heinrich of 20 April, in which he reprimanded the Reichstag and insulted its deputies for having rejected large parts the navy budget. The letter's content was leaked to the public after having been read out by Heinrich to the crew of his cruiser.

${ }^{{ }^{13} 3}$ Walther Bronsart von Schellendorff; on I4 August I896.

${ }^{514}$ Lascelles is referring to a trial against two journalists at the end of which, on 7 December 1896, Eugen von Tausch, superintendent of the political police, was arrested for perjury. Tausch, who had sold confidential information to the press and disseminated political misinformation, was on trial from 24 May to 4 June 1897 and was ultimately acquitted.

${ }^{15}$ The Military Penal Code was presented to the Federal Council by Prussia on 8 May 1897. See n. 186 in Munich section.

${ }_{516}^{16}$ On 27 June 1896.

${ }^{517}$ Lascelles is referring to the bill respecting the right of assembly and association introduced in the Prussian house of deputies on I3 May I897. It was rejected on 24 July.
} 
And while the Government thus appears to be continually hampered by a hidden opposition, statements are publicly made by the highest authority reflecting on the representative body as a whole, or on individual parties; or, as in the case of the naval estimates, proposals from the same source are submitted to the Reichstag, which the Ministers have never even seen..$^{1+8}$ [Note in margin: 'No 89 March 26']

The socialists have been branded as "enemies of their country"; $;^{519}$ even the Conservatives have been characterized as "grumblers"; 520 The Reichstag as a body has been described as a set of men "who did not know what patriotism meant" ${ }^{221}$ and [Note in margin: No I36; May I4] as a "crew unworthy of the name of Germans". ${ }^{522}$ No minister can be made responsible for these statements, and language in self defence comes under the law of high treason.

The position of the Ministers themselves can be judged by the action of the Chancellor ${ }^{523}$ above quoted and by recent events in the domain of foreign policy. ${ }^{524}$

Under these circumstances it is not surprising if, at the present moment, the rumours of a ministerial crisis are renewed, and if, from almost every quarter, expressions of discontent are making themselves heard.

\section{FO 64/I410: Frank C. Lascelles to Marquess of Salisbury, No I4I, Berlin, 20 May 1897}

[Received 23 May. For: Duke of Devonshire / Mr Balfour, A.J. B. [Arthur James Balfour] / Intelligence Division (War Office) / Commercial Department / African Department; S[alisbury]]

Discussion of emigration bill; no formal emigration policy but attempts to direct migrants to colonies

I have the honour to inform Your Lordship with reference to my Despatch $\mathrm{N}^{\mathrm{O}}$ I2I of the $8^{\text {th }}$ Instant that the Emigration Bill has been read a third time in the Reichstag. ${ }^{525}$

\footnotetext{
${ }^{{ }^{18}}$ The navel estimates, which reflected Wilhelm II's intention to expand the German navy, were decreased by the budget committee and passed by the Reichstag on 28 March I897.

${ }^{{ }^{19} 9}$ Wilhelm II on I4 May I889, at an audience with a delegation of striking coal miners.

${ }^{520}$ Wilhelm II, in a speech to the members of the provincial diet of Brandenburg, on 24

February I894 .

${ }^{521}$ Wilhelm II, in a telegram to Prince Heinrich of 20 April I897.

${ }^{522}$ Not a literal quote. Lascelles is referring to Wilhelm's telegram to Bismarck of 23

March 1885, after the Reichstag refused to congratulate Bismarck on his $80^{\text {th }}$ birthday.

${ }^{523}$ Chlodwig zu Hohenlohe-Schillingsfürst.

${ }^{524}$ Lascelles is referring to anti-Greek policy (and Wilhelm II's plan to blockade Greece) in the run-up to, and during, the Greco-Turkish War (5 April to 8 May 1897).

${ }^{525}$ The bill was passed on I9 May I897; it came into effect (as the law of 9 June I897) on I April I898.
} 
In addition to the Bill, resolutions (drawn up by the special committee to which the bill had been referred) were passed, one urging the appointment of Consuls in the harbours frequented by German Emigrants in order to look after their interests and the other advocating measures to make it easier for Germans born, or living, abroad to perform their military service.

The House then considered two further resolutions proposed by a private member. ${ }^{526}$ The first urged the Government to use the means at their disposal in order to "guide the stream of emigration, as much as possible, to those countries where in addition to finding means of earning a livelihood German Emigrants have the best chance of maintaining their nationality (Deutschtum) as well as good relations with their old home."

After a favourable statement on the part of the Government this resolution was passed.

A second resolution asking the Government to lay a bill before the House for the Colonization of the German Protectorates was however rejected.

It was stated that the only Protectorate suitable to Colonization was South West Africa and that experiments with a view to discovering whether or not it was suitable for small farmers were now being made. The Government was taking the necessary practical measures and no further steps were required at present.

I have already had the honour to draw Your Lordship's attention to the importance of the principle embodied in these resolutions. Although the Government Representatives did not formally give expression to an emigration policy (which appears, however, to have been communicated to the Committee) having for its object the establishment under foreign flags, of bodies of Colonists owing allegiance to Germany, performing services for the Mother Country, such a policy has been for long advocated in Germany; and, from the terms of the Government Bill and from Baron von Marschall's speech on the objects of a navy (See my Despatch $\mathrm{N}^{\mathrm{O}} 92$ of the $27^{\text {th }} \mathrm{March}$ ) ${ }^{527}$ appears to have been fully adopted by the Government.

\footnotetext{
${ }^{526}$ Paul Förster.

${ }^{527}$ Lascelles is referring to Marschall's Reichstag speech in the second reading of the navy estimates on 18 March I897.
} 


\section{FO 64/I4I I: Frank C. Lascelles to Marquess of Salisbury, No I8o, Berlin, I July 1897}

[Received 5 July by bag. Seen by the Chief Clerk [stamped]; For: The Queen / Prince of Wales / Brussels / Admiralty; S[alisbury]]

Banquet in honour of Queen Victoria's diamond jubilee on board Hohenzollern at Kiel; emperor's affectionate speech

On the 27th ultimo The Emperor gave a banquet on board His Majesty's Yacht "Hohenzollern" at Kiel in commemoration of the Queen's Jubilee, ${ }^{528}$ to which all the members of Her Majesty's Embassy at present at Berlin had the honour of being invited, as well as the owners of the English yachts who had come to take part in the Kiel Regatta.

The German Ships of War in the Harbour were all flying the White Ensign.

During the Dinner The Emperor rose and speaking in German welcomed The King of the Belgians who was present and announced that he had appointed His Majesty an Admiral "à la suite" ${ }^{299}$ of the German Navy. He expressed the hope that the friendly relations between the two countries which were of a commercial rather than a political character might be still further developed, and concluded by asking His Majesty's permission to propose the toast of The Queen.

Then, speaking in English, His Majesty bade a cordial welcome to his English guests to whom he was glad to give an opportunity of drinking The Queen's health, a toast which could nowhere be more appropriately honoured than on board a ship on blue water. In touching terms he described his admiration of The Queen, to whom he alluded as the wisest Sovereign in Europe and said that every German Officer in command of [a] ship felt honoured that day by flying the White Ensign in celebration of Her Majesty's Jubilee. In conclusion His Majesty called for three cheers for The Queen which he led himself.

The King of the Belgians expressed his thanks for the honour which The Emperor had conferred upon him, expressed the hope that German ships would come in greater numbers to Antwerp and concluded by proposing the health of The Emperor and Empress. ${ }^{530}$ The effect of His Majesty's speech was somewhat marred

\footnotetext{
${ }^{528}$ Victoria celebrated the $60^{\text {th }}$ anniversary of her reign (her Diamond Jubilee) on 22 June 1897 .

529 'In the entourage of'; an honorary military title with no official position.

${ }^{53^{\circ}}$ Auguste Viktoria.
} 
by its being delivered during the firing of the Royal Salute in honour of the Queen.

\section{FO 64/I4I I: Frank C. Lascelles to Marquess of Salisbury, No I84, Berlin, 2 July 1897}

[Received 5 July by bag. For: The Queen / Prince of Wales / Duke of Devonshire / Mr Balfour, A.J.B. [Arthur James Balfour]; S[alisbury]]

Marschall replaced by Bülow as foreign minister; new incumbent a triumph for Agrarian Party

I have the honour to enclose a translation of a notification published on the 28th ultimo by Wolff's Telegraphic Bureau and reproduced by all the German Newspapers to the effect that the state of Baron von Marschall's health has made it necessary that he should be replaced at the Ministry for Foreign Affairs and that Herr von Bülow has temporarily been charged by The Emperor with the direction of that Office. ${ }^{531}$

It has been generally known for several months past that Baron von Marschall had fallen out of favour with The Emperor, and His Majesty is reported to have said at the conclusion of the Tausch Trial, that the acquittal of von Tausch made it impossible that Baron von Marschall should remain in Office. ${ }^{532}$

I have been informed that Baron von Marschall's health has greatly improved since he left Berlin, ${ }^{533}$ and at that time he had certainly no intention of resigning his Office. He told me on the very day of his departure that he expected to return to Berlin about the middle of August and that he hoped to obtain a further leave of absence in September.

The state of his health therefore can only be regarded as a pretext for his dismissal, and I am informed that it was only through the newspapers that he became aware of any intention on the part of the Emperor to remove him from Office.

In speaking to me on this subject this morning, Baron von Rotenhan told me that Baron von Marschall had written a letter to the Chancellor ${ }^{53}$ placing himself entirely in his hands in case it should be found advisable, in order to avert a crisis, to entrust the Ministry for Foreign Affairs to some other Minister, but there is

\footnotetext{
${ }^{53 \mathrm{I}}$ Marschall was officially dismissed on i9 October i897. Enclosure: translation of Wolff's telegraphic correspondence, Kiel, 28 June I897.

${ }^{532}$ For the Tausch trial see n. $5^{\mathrm{I} 4}$ in this section.

${ }^{533}$ Marschall was on leave of absence from 4 June I897.

534 24 June 1897.
} 
reason to believe that this letter was written after Baron von Marschall had learned from the Public Press that his position was threatened.

The want of consideration with which Baron von Marschall has been treated is also evidenced by the fact that Herr von Bülow will only take possession of his post after The Emperor's return to Berlin about the middle of August, at the very time when Baron von Marschall had intended to resume his duties.

Herr von Bülow's appointment is generally considered as a triumph of the Agrarian Party and to indicate the adoption of a reactionary policy, an opinion which has been strengthened by a visit ${ }^{535}$ which Prince Hohenlohe and Herr von Bülow paid to Prince Bismarck on their return from Kiel.

\section{FO 64/14II: Frank C. Lascelles to Marquess of Salisbury, No 259, Berlin, 27 September 1897}

[Received 4 October by bag. For: Duke of Devonshire / Mr Balfour / Admiralty, 8 October; S[alisbury]]

\section{Kölnische Zeitung on naval bill}

With reference to my despatch No 253 of the I7th instant, I have the honour to report that the Cologne Gazette, in its issue of the 24th instant, publishes an article on the subject of the naval construction Bill which is to be presented to the Reichstag ${ }^{536}$ in which it condemns the agitation against the measure in which Herr Eugen Richter the leader of the Radical Party ${ }^{537}$ has for some time been engaged.

The Article points out that even the more moderate sections of the German Press had previously been somewhat alarmed, because words spoken in the highest places had led to the belief that the Government desired to create a fleet equal to that of France, but that the appointment ${ }^{538}$ of Admiral Tirpitz to be Secretary of State for the Navy had removed these apprehensions, as his moderation could be relied upon.

It goes on to say that according to information obtained from sources in touch with the Federal Council, the new bill will make

\footnotetext{
${ }^{535}$ On 28 June 1897.

${ }^{53^{6}}$ The naval bill, which authorized the maintenance of nineteen battleships and the building of seven vessels, was introduced in the Reichstag on 30 November I897 and passed on 28 March I898. It became law on io April I898.

${ }^{537}$ Deutsche Freisinnige Partei.

${ }^{538}$ On I8 June I897.
} 
no excessive demands but will merely be designed to restore the fleet to its former level of efficiency. Experience has shown that the vessels of the "Siegfried" class although excellent ships in themselves are not suitable as a uniform type, which is a necessity for the German navy. ${ }^{539}$ The type required is one which does not exceed I2,000 tons, as a larger size would not be convenient for the Kaiser Wilhelm Canal or the general conditions of the German Coast. Accordingly a uniform type for battleships of about the above tonnage is proposed. The programme extends to the year $1905^{54^{\circ}}$ and on an average the annual expenditure will not greatly exceed that demanded this year. The estimate for ship- building in the first year of this programme will be about $2 \frac{1}{2}$ million sterling, in the following years somewhat more than 3 millions in each year. To this must be added a permanent increase of annual expenditure of about $£ 5$ oo,ooo for the necessary increase of the personnel.

\section{FO 64/1412: Frank C. Lascelles to Marquess of Salisbury, No 301 , Berlin, 13 November 1897}

[Received I5 November by messenger. For: The Queen / Prince of Wales / Duke of Devonshire / Mr Balfour, A.J.B. [Arthur James Balfour]; S[alisbury]]

\section{Last Reichstag session before elections; fortunes of the major political parties since the last sitting in Fune}

I have the honour to inform Your Lordship that it is stated in the Reichs Anzeiger ${ }^{5+1}$ that the Reichstag is summoned to meet on the $30^{\text {th }}$ instant. It is generally believed that immediately on its reassembly the Government will communicate the proposals for the increase of the navy and the reform of the military judicial procedure..$^{54^{2}}$ The present Reichstag meets for the last time and preparations are being actively made for the elections which must take place next year. ${ }^{543}$

The recess $\mathrm{S}^{54}$ has been marked by an evident growth of "particularism", - anti-Prussian or anti-imperial sentiment - in various parts of Germany. The debates in the Bavarian parliament have been strongly tinged with anti-Prussian feeling; the national Liberals

\footnotetext{
539 The eight Siegfried class vessels, built between I888 and I896, were coastal defence ships (displacement of 3,500 tons).

$54^{\circ}$ The final law stipulated the fiscal year 1903 .

${ }^{541}$ Deutscher Reichsanzeiger und Königlich Preußischer Staatsanzeiger, II November I897. The imperial rescript was dated io November.

${ }^{542}$ For the imperial naval bill see $n .536$ in this section; for the German Military Penal Code see n. 186 in Munich section.

${ }^{543}$ Elections were held on I6 June 1898.

${ }^{544}$ The last sitting of the Reichstag was on 25 June 1897.
} 
have for the first time lost control of the legislature of Baden; and the agitation in Brunswick for the restoration of the legitimate dynasty has assumed considerable proportions. ${ }^{545}$

With regard to the movement of parties it would seem that the long continued struggle in connection with the military Jurisdiction bill had increased the forces of the left; but on the other hand a fierce dispute has broken out between the adherents and opponents of Herr Eugen Richter which must end by impairing the strength of the party and has already resulted in disaster at the polls. ${ }^{54^{6}}$

The Social Democrats hitherto a model of discipline, have also developed an internal question which is causing the party considerable difficulty. At a recent party meeting it was decided to take part in the Prussian [sic] elections but under the condition that the Socialist voter should only vote for Socialist candidates. ${ }^{547}$ This resolution was strongly opposed on the ground that it would only tend to strengthen the forces of the Conservatives and will undoubtedly have this effect at the next Prussian elections which are also to take place next year. ${ }^{54^{8}}$ The attitude of the centre which holds the balance of the Reichstag and which is a perfectly organized party is still doubtful. A demand has recently been made on the Chancellor by the leader of this party for the abrogation of the law still in force against the Jesuits. ${ }^{549}$ This demand has been refused.

The chief losers during the present Reichstag have been the Conservative party. They have already lost ten seats since the last election $^{55^{\circ}}$ and recently they have lost a seat in a district ${ }^{55^{1}}$ where they had hitherto undisputed control. This latter defeat appears to have been due, not to an increase of the liberal vote but to the revolt of the extremists of their own party who preferred to vote for a

\footnotetext{
${ }^{545}$ Lascelles is referring to the elections of the Baden Landtag on 28 October 1897. For the events in Bavaria see pp. 550-552; for the Brunswick succession question, which was kept in discussion by the Guelph Braunschweigisch Landes-Rechts-Partei, see n. 65 in this section.

${ }^{546}$ Lascelles is referring to the Landtag elections in Saxony of September and October I897 when all candidates of the Freisinnige Volkspartei failed to win seats. The dispute was brought about by Richter's refusal to cooperate with the liberal Demokratische Volkspartei (Progressives) in order to avoid competing candidatures in the Reichstag elections of 1898.

${ }^{547}$ Lascelles is referring to the conference of the Sozialdemokratische Partei at Hamburg from 3 to 9 October I897; the resolution concerning the candidacy for Landtag elections was passed on 6 October.

${ }^{54^{8}}$ The elections for the Prussian house of deputies were held on 3 November I898.

${ }^{549}$ In a conversation with Hohenlohe on 28 October Ernst Lieber - in exchange for the Zentrum's support of the navy bill - demanded that Article 2 of the Anti-Jesuit Law (of 4July I872) be rescinded. This made it possible to restrict freedom of residence for Jesuits and to banish foreign members of the Jesuit order from Germany.

${ }^{55^{\circ}}$ Elections took place on I5 June I893.

${ }^{55^{1}}$ By-election in the electoral district of Westprignitz on 8 November I897.
} 
radical rather than to support their former leaders. The augury for the next election is not encouraging and it is the more unfortunate for the Government as in the last two years the Government has initiated legislation in the interests of this party which has left a deep feeling of animosity in industrial and financial circles, which cannot fail to bear fruit in the coming elections.

But while the general tendency of party movement is a trend to the left the recent reconstitution of the Government is considered to show that in the highest circles the trend is in the opposite direction..$^{52}$

${ }^{552}$ Lascelles is referring to the replacements of Boetticher as vice chancellor and state secretary of the imperial office of the interior, Hollmann as state secretary of the naval office, and Marschall as state secretary for foreign affairs. 